\title{
Neonatal interventions for preventing cerebral palsy: an overview of Cochrane Systematic Reviews (Review)
}

Shepherd E, Salam RA, Middleton P, Han S, Makrides M, Mclntyre S, Badawi N, Crowther CA

Shepherd E, Salam RA, Middleton P, Han S, Makrides M, McIntyre S, Badawi N, Crowther CA.

Neonatal interventions for preventing cerebral palsy: an overview of Cochrane Systematic Reviews.

Cochrane Database of Systematic Reviews 2018, Issue 6. Art. No.: CD012409.

DOI: 10.1002/14651858.CD012409.pub2.

www.cochranelibrary.com

Neonatal interventions for preventing cerebral palsy: an overview of Cochrane Systematic Reviews (Review) Copyright $\odot 2018$ The Cochrane Collaboration. Published by John Wiley \& Sons, Ltd. 
HEADER 1

ABSTRACT

PLAIN LANGUAGE SUMMARY

BACKGROUND

OBJECTIVES

METHODS

RESULTS

Figure 1.

DISCUSSION

AUTHORS' CONCLUSIONS

ACKNOWLEDGEMENTS

REFERENCES

ADDITIONAL TABLES

APPENDICES

CONTRIBUTIONS OF AUTHORS

DECLARATIONS OF INTEREST

SOURCES OF SUPPORT

INDEX TERMS

\section{TABLE OF CONTENTS}


[Overview of Reviews]

\section{Neonatal interventions for preventing cerebral palsy: an overview of Cochrane Systematic Reviews}

Emily Shepherd ${ }^{1}$, Rehana A Salam², Philippa Middleton ${ }^{3}$, Shanshan Han ${ }^{1}$, Maria Makrides 3 , Sarah Mclntyre ${ }^{4}$, Nadia Badawi ${ }^{4,5}$, Caroline A Crowther6

1ARCH: Australian Research Centre for Health of Women and Babies, Robinson Research Institute, Discipline of Obstetrics and Gynaecology, The University of Adelaide, Adelaide, Australia. 2Division of Women and Child Health, Aga Khan University Hospital, Karachi, Pakistan. ${ }^{3}$ Healthy Mothers, Babies and Children, South Australian Health and Medical Research Institute, Adelaide, Australia. ${ }^{4}$ Research Institute, Cerebral Palsy Alliance, University of Sydney, Sydney, Australia. ${ }^{5}$ Grace Centre for Newborn Care, The Children's Hospital at Westmead, Sydney, Australia. 6 Liggins Institute, The University of Auckland, Auckland, New Zealand

Contact address: Emily Shepherd, ARCH: Australian Research Centre for Health of Women and Babies, Robinson Research Institute, Discipline of Obstetrics and Gynaecology, The University of Adelaide, Adelaide, South Australia, 5006, Australia. emily.shepherd@adelaide.edu.au.

Editorial group: Cochrane Neonatal Group.

Publication status and date: New, published in Issue 6, 2018.

Citation: Shepherd E, Salam RA, Middleton P, Han S, Makrides M, McIntyre S, Badawi N, Crowther CA. Neonatal interventions for preventing cerebral palsy: an overview of Cochrane Systematic Reviews. Cochrane Database of Systematic Reviews 2018, Issue 6. Art. No.: CD012409. DOI: 10.1002/14651858.CD012409.pub2.

Copyright $\odot 2018$ The Cochrane Collaboration. Published by John Wiley \& Sons, Ltd.

\section{A B S T R A C T}

\section{Background}

Cerebral palsy is an umbrella term that encompasses disorders of movement and posture attributed to non-progressive disturbances occurring in the developing foetal or infant brain. As there are diverse risk factors and aetiologies, no one strategy will prevent cerebral palsy. Therefore, there is a need to systematically consider all potentially relevant interventions for prevention.

\section{Objectives}

Primary

To summarise the evidence from Cochrane Systematic Reviews regarding effects of neonatal interventions for preventing cerebral palsy (reducing cerebral palsy risk).

\section{Secondary}

To summarise the evidence from Cochrane Systematic Reviews regarding effects of neonatal interventions that may increase cerebral palsy risk.

\section{Methods}

We searched the Cochrane Database of Systematic Reviews (27 November 2016) for reviews of neonatal interventions reporting on cerebral palsy. Two review authors assessed reviews for inclusion, extracted data, and assessed review quality (using AMSTAR and ROBIS) and quality of the evidence (using the GRADE approach). Reviews were organised by topic; findings were summarised in text and were tabulated. Interventions were categorised as effective (high-quality evidence of effectiveness); possibly effective (moderate-quality evidence of effectiveness); ineffective (high-quality evidence of harm); probably ineffective (moderate-quality evidence of harm or lack of effectiveness); and no conclusions possible (low- to very low-quality evidence). 


\section{Main results}

Forty-three Cochrane Reviews were included. A further 102 reviews pre-specified the outcome cerebral palsy, but none of the included randomised controlled trials (RCTs) reported this outcome. Included reviews were generally of high quality and had low risk of bias, as determined by AMSTAR and ROBIS. These reviews involved 454 RCTs; data for cerebral palsy were available from 96 (21\%) RCTs involving 15,885 children. Review authors considered interventions for neonates with perinatal asphyxia or with evidence of neonatal encephalopathy (3); interventions for neonates born preterm and/or at low or very low birthweight (33); and interventions for other specific groups of 'at risk' neonates (7). Quality of evidence (GRADE) ranged from very low to high.

\section{Interventions for neonates with perinatal asphyxia or with evidence of neonatal encephalopathy}

\section{Effective interventions: high-quality evidence of effectiveness}

Researchers found a reduction in cerebral palsy following therapeutic hypothermia versus standard care for newborns with hypoxic ischaemic encephalopathy (risk ratio (RR) $0.66,95 \%$ confidence interval (Cl) 0.54 to 0.82 ; seven trials; 881 children).

\section{No conclusions possible: very low-quality evidence}

One review observed no clear differences in cerebral palsy following therapeutic hypothermia versus standard care.

\section{Interventions for neonates born preterm and/or at low or very low birthweight}

\section{Possibly effective interventions: moderate-quality evidence of effectiveness}

Researchers found a reduction in cerebral palsy with prophylactic methylxanthines (caffeine) versus placebo for endotracheal extubation in preterm infants ( $\mathrm{RR} 0.54,95 \% \mathrm{Cl} 0.32$ to 0.92 ; one trial; 644 children).

\section{Probably ineffective interventions: moderate-quality evidence of harm}

Researchers reported an increase in cerebral palsy ( $\mathrm{RR} 1.45,95 \% \mathrm{Cl} 1.06$ to $1.98 ; 12$ trials; 1452 children) and cerebral palsy in assessed survivors (RR 1.50, 95\% Cl 1.13 to 2.00; 12 trials; 959 children) following early (at less than eight days of age) postnatal corticosteroids versus placebo or no treatment for preventing chronic lung disease in preterm infants.

\section{Probably ineffective interventions: moderate-quality evidence of lack of effectiveness}

Trial results showed no clear differences in cerebral palsy following ethamsylate versus placebo for prevention of morbidity and mortality in preterm or very low birthweight infants (RR 1.13, $95 \% \mathrm{Cl} 0.64$ to 2.00 ; three trials, 532 children); volume expansion versus no treatment (RR 0.76, 95\% Cl 0.48 to 1.20; one trial; 604 children); gelatin versus fresh frozen plasma (RR 0.94, 95\% $\mathrm{Cl} 0.52$ to 1.69 ; one trial, $399 \mathrm{children)}$ for prevention of morbidity and mortality in very preterm infants; prophylactic indomethacin versus placebo for preventing mortality and morbidity in preterm infants (RR 1.04, 95\% Cl 0.77 to 1.40; four trials; 1372 children); synthetic surfactant versus placebo for respiratory distress syndrome in preterm infants ( $\mathrm{RR} 0.76,95 \% \mathrm{Cl} 0.55$ to 1.05 ; five trials; 1557 children); or prophylactic phototherapy versus standard care (starting phototherapy when serum bilirubin reached a pre-specified level) for preventing jaundice in preterm or low birthweight infants (RR 0.96, 95\% Cl 0.50 to 1.85; two trials; 756 children).

\section{No conclusions possible: low- to very low-quality evidence}

No clear differences in cerebral palsy were observed with interventions assessed in 21 reviews.

\section{Interventions for other specific groups of 'at risk' neonates}

\section{No conclusions possible: low- to very low-quality evidence}

Review authors observed no clear differences in cerebral palsy with interventions assessed in five reviews.

\section{Authors' conclusions}

This overview summarises evidence from Cochrane Systematic Reviews regarding effects of neonatal interventions on cerebral palsy, and can be used by researchers, funding bodies, policy makers, clinicians, and consumers to aid decision-making and evidence translation. To formally assess other benefits and/or harms of included interventions, including impact on risk factors for cerebral palsy, review of the included Reviews is recommended.

Therapeutic hypothermia versus standard care for newborns with hypoxic ischaemic encephalopathy can prevent cerebral palsy, and prophylactic methylxanthines (caffeine) versus placebo for endotracheal extubation in preterm infants may reduce cerebral palsy risk. Early (at less than eight days of age) postnatal corticosteroids versus placebo or no treatment for preventing chronic lung disease in preterm infants may increase cerebral palsy risk. 
Cerebral palsy is rarely identified at birth, has diverse risk factors and aetiologies, and is diagnosed in approximately one in 500 children. To date, only a small proportion of Cochrane Systematic Reviews assessing neonatal interventions have been able to report on this outcome. There is an urgent need for long-term follow-up of RCTs of such interventions addressing risk factors for cerebral palsy (through strategies such as data linkage with registries) and for consideration of the use of relatively new interim assessments (including the General Movements Assessment). Such RCTs must be rigorous in their design and must aim for consistency in cerebral palsy outcome measurement and reporting to facilitate pooling of data and thus to maximise research efforts focused on prevention.

\section{PLAIN LANGUAGE SUMMARY}

Interventions for babies from birth to one month of life for preventing cerebral palsy: an overview of Cochrane Systematic Reviews

\section{What is the issue?}

'Cerebral palsy' is a term that includes a group of conditions affecting people's ability to move; it is the most common physical disability in childhood. Cerebral palsy is usually due to events before, during, or after childbirth that lead to injury to babies' developing brains. No single cause of cerebral palsy is known. For many children, the cause of cerebral palsy is unclear, but many risk factors are known. The biggest risk factor is preterm birth (birth before 37 weeks of pregnancy). Other risk factors during the neonatal period (birth to one month of life) include prolonged loss of oxygen during birth; brain injury; strokes or seizures; disorders of the heart, blood vessels, airways, and lungs; prolonged mechanical assistance for breathing; some infections; jaundice (yellow discolouration of the skin and eyes due to excess bilirubin in the blood); and some syndromes or abnormalities of chromosomes (structures that hold genes).

\section{Why is this important?}

As there are different risk factors for and causes of cerebral palsy, it is likely that different interventions may be needed to prevent cerebral palsy by reducing risk factors. This overview summarises evidence about preventing cerebral palsy that has been presented in Cochrane Systematic Reviews of interventions during the neonatal period.

\section{What evidence did we find?}

We searched for evidence on 27 November 2016, and identified 43 Cochrane Reviews assessing interventions during the neonatal period that reported some information on cerebral palsy. These Reviews were all of moderate to high quality, but the quality of the evidence about cerebral palsy ranged from very low to high. Three Reviews assessed interventions for newborn babies who may have had a lack of oxygen at or around the time of birth; 33 Reviews assessed interventions for babies born preterm or at low birthweight; and seven Reviews assessed interventions for other groups of newborn babies at risk of injury to their brains (such as newborn babies with low blood sugar at birth).

We found that one intervention was effective for cerebral palsy prevention. Newborn babies who may have had a lack of oxygen at or around the time of birth who had induced hypothermia (cooling of their body or just their brain) were less likely to develop cerebral palsy than babies who did not receive hypothermia (seven trials; 881 children; high-quality evidence). We found that one intervention was possibly effective for cerebral palsy prevention. Preterm newborns who received methylxanthines (caffeine) when weaning from machine-assisted breathing (extubation from mechanical ventilation) was planned were less likely to develop cerebral palsy than babies who received a placebo (one trial; 644 children; moderate-quality evidence). We found one intervention that was probably ineffective and may cause harm: Preterm newborns who received early (at less than eight days of age) corticosteroids to prevent chronic lung disease were more likely to develop cerebral palsy than babies who received a placebo (12 trials; 959 children; moderate-quality evidence). We found that five other interventions were probably ineffective (did not prevent or increased the chance of cerebral palsy) (moderate-quality evidence). Review authors did not find enough evidence to say whether the other interventions prevented, increased, or had no impact on cerebral palsy (low- or very low-quality evidence).

\section{What does this mean?}

This overview identified one intervention that was effective in preventing cerebral palsy (induced hypothermia for newborn babies who may have had a lack of oxygen), one that was possibly effective for preventing cerebral palsy (caffeine for preterm babies weaning from machine-assisted breathing), one that appeared to cause harm (corticosteroids at less than eight days of age for preterm babies to prevent chronic lung disease), and five that did not appear to make a difference. For the other interventions assessed, there was not enough evidence to allow conclusions. It is important that additional good quality trials assessing interventions that might impact cerebral palsy risk factors conduct long-term follow-up to measure the impact of these interventions. We identified over 100 other Cochrane Reviews that may in the future provide information on interventions during the neonatal period for preventing cerebral palsy if they include longterm follow-up. 


\section{B A C K G R O U N D}

\section{Description of the condition}

\section{Cerebral palsy: definition and prevalence}

'Cerebral palsy' was originally (and continues to be) defined by clinical description at a time when there was little knowledge of aetiology or pathology (Morris 2007). Today, many registries and surveillance programmes, including those in Australia, the United Kingdom, and Europe, highlight five key elements of cerebral palsy: It is an 'umbrella term'; it is permanent but not unchanging; it involves a disorder of movement or posture or both, and of motor function; it is due to a non-progressive interference, lesion, or abnormality; and the interference, lesion, or abnormality arose in the developing or immature brain (Cans 2000; Mutch 1992; Rosenbaum 2007; Smithers-Sheedy 2014). As cerebral palsy is defined by clinical description, which may change over time, a longer time span for diagnosis is considered useful to confirm that the condition meets criteria for cerebral palsy and to accurately describe the motor impairment. Thus, final ascertainment for surveillance programmes across the world ranges from four to 12 years, with many considering data to be 'complete' at or near five years (Smithers-Sheedy 2014). Although average age at diagnosis has been around 18 months, recent evidence has suggested that cerebral palsy may be reliably detected as early as three to four months' post term age via tests such as Prechtl's Qualitative Assessment of General Movements and medical resonance imaging (Bosanquet 2013; Morgan 2016).

Cerebral palsy is the most common physical disability in childhood. In a recent meta-analysis, including 19 studies (with varying ages of ascertainment), the global pooled prevalence was 2.11 per 1000 live births (95\% confidence interval (CI) 1.98 to 2.25); a cumulative meta-analysis demonstrated stability over the past 10 years (Oskoui 2013). Similar rates have been reported in countries that have used consistent methods of ascertainment for over 20 years (such as Australia, Sweden, and England), with most published estimates in the region of 2 per 1000 (Blair 2006). In low- and middle-income countries, prevalence estimates have tended to be in a similar range or higher (Blair 2006; Cans 2000). However, emerging evidence, including rates from Australia and Europe, now shows that overall rates and severity of the condition are starting to decline for the first time (Reid 2015; Sellier 2015).

\section{Cerebral palsy: causes and risk factors}

Brain injury was acquired during an event more than 28 days after birth in approximately $6 \%$ of individuals with cerebral palsy (ACPR Group 2013). In the remaining $94 \%$ of individuals, brain injury occurred during pregnancy, at birth, or over the first 28 days of life (ACPR Group 2013). Preterm birth is one of the principal risk factors for cerebral palsy and associated neurosensory disabilities (Himpens 2008; Oskoui 2013), with over $40 \%$ of individuals with cerebral palsy born preterm (ACPR Group 2013). However, more than half of all individuals with cerebral palsy are born at term (ACPR Group 2013).

Studies on antenatal, intrapartum, and neonatal risk factors for cerebral palsy are abundant. Although a great number of risk factors have been identified, their commonality is that separately, or in combination, they influence potentially preventable pathways to brain injury. Risk factors commonly reported include (i) factors before conception (e.g. low or advanced maternal age, high parity, nulliparity, a short or long interpregnancy interval, a history of stillbirth, multiple miscarriages, neonatal death or preterm birth, family history of cerebral palsy and other genetic predispositions, low socioeconomic status, pre-existing maternal conditions (such as epilepsy or intellectual disability)); (ii) factors in early pregnancy (e.g. male sex, multiple gestation, congenital malformations or birth defects, infections (such as TORCH complex - toxoplasmosis (parasite), other infections, rubella, cytomegalovirus, herpes simplex virus)); (iii) factors during pregnancy (e.g. maternal disease (such as thyroid disorders), pregnancy complications (such as pre-eclampsia, placenta praevia, and placental abruption), intrauterine infection or inflammation and chorioamnionitis, intrauterine growth restriction, other precursors to preterm birth); and (iv) factors around the time of birth and the neonatal period (e.g. acute intrapartum hypoxic events and neonatal encephalopathy, neonatal brain injury (such as intraventricular haemorrhage, periventricular leucomalacia, and hydrocephalus), strokes or seizures, cardiovascular disorders (such as patent ductus arteriosus and hypotension), respiratory disorders, associated prolonged ventilation (such as for respiratory distress syndrome or bronchopulmonary dysplasia), infection (such as sepsis and necrotising enterocolitis), metabolic or endocrine disorders (such as hypoglycaemia and hypothyroidism), neonatal jaundice along with inborn errors of metabolism, particular syndromes or chromosomal abnormalities) (Badawi 2005; Dixon 2002; Drougia 2007; Jacobsson 2004; McIntyre 2011; McIntyre 2013; Murphy 1997; Nelson 2008; Tran 2005; Walstab 2004).

Research has shown that contrary to previous beliefs, birth asphyxia is a relatively rare cause of cerebral palsy (Blair 1988; Ellenberg 2013). A growing body of evidence suggests that genetic abnormalities contribute in some cases (MacLennan 2015; Moreno-De-Luca 2012; O'Callaghan 2009; Oskoui 2015). Common risk factors in the post-neonatal period (some of which also contribute in the neonatal period) include infection (such as meningitis/encephalitis, or severe infection and subsequent severe dehydration), head injury (such as from traffic accidents, other traumatic injury, or non-accidental injury), vascular episodes (such as post cardiac or brain surgery), and other events (such as near drowning or near sudden infant death) (Cans 2004; Germany 2013).

\section{Cerebral palsy: consequences}

Cerebral palsy, the leading cause of physical disability for children, is a condition with lifelong impact. Most individuals will survive to adulthood, and some studies suggest that life expectancy can be similar to that of the general population (Colver 2012). For known cases of antenatally or neonatally acquired cerebral palsy, the 20-year survival rate has been estimated at $90 \%$. However, strong associations between increasing motor impairment, severe intellectual impairment, number of severe impairments, and early mortality have been shown (Blair 2001; Hemming 2005; Reid 2012). Frequently used definitions for cerebral palsy acknowledge common co-occurring impairments, diseases, and functional limitations (Rosenbaum 2007). A recent systematic review estimated that among children with cerebral palsy, " 1 in 2 had an intellectual disability...1 in 4 could not talk; 1 in 4 had epilepsy; 1 in 4 had a behavior disorder...1 in 10 were blind... and 1 in 25 were deaf" (Novak 2012).

Economic studies have estimated lifetime costs of cerebral palsy, including healthcare, social care, and productivity costs, as EUR 860,000 for men and EUR 800,000 for women in Denmark (in 2000) 
(Kruse 2009), and as USD 921,000 for individuals in the United States (in 2003) (CDC 2004). In Australia, the financial cost of cerebral palsy was estimated as AUD 1.47 billion (in 2007), and the value of lost well-being a further AUD 2.4 billion (Access Economics 2008).

The impact of cerebral palsy is considerable (Davis 2010). Accordingly, identification of primary preventive measures has been regarded as a key priority among individuals with cerebral palsy, their families, clinicians, and researchers (McIntyre 2010).

\section{Description of the interventions}

\section{Neonatal approaches to prevention of cerebral palsy}

Research efforts aimed at prevention of cerebral palsy have increasingly focused on understanding the causes of cerebral palsy. As it is now widely recognised that causes differ, for example, by gestational age (e.g. for preterm and term-born children) and by clinical subtype of cerebral palsy, it is reasonable to consider that successful primary preventive interventions will also vary according to different aetiologies or causal factors.

In this overview, therefore, we will include a broad range of neonatal interventions (with varying primary aims or indications) that may mediate cerebral palsy risk, including (but not limited to):

1. interventions for neonates following birth asphyxia or with evidence of encephalopathy (e.g. cooling; erythropoietin; darbepoetin; allopurinol; melatonin; magnesium sulphate; anticonvulsants; xenon; naloxone; dopamine; fluid restriction; acupuncture; umbilical cord stem cells);

2. interventions for neonates with neurological disorders, such as intracranial haemorrhage or post-haemorrhagic hydrocephalus (e.g. heparin; antithrombin; phenobarbital; diuretic therapy; erythropoietin; repeated lumbar or ventricular punctures); or those with seizures (anticonvulsants);

3. interventions for neonates requiring resuscitation (e.g. air or oxygen for positive-pressure ventilation; lower or higher oxygen concentrations titrated to target oxygen saturations; face mask, laryngeal mask airway, nasal airway or endotracheal intubation; positive end-expiratory pressure; respiratory function monitoring);

4. interventions for neonates with cardiovascular disorders, such as hypotension (e.g. corticosteroids; inotropes; early volume expansion; adrenaline; dopamine; dobutamine) or patent ductus arteriosus (e.g. ibuprofen; indomethacin; fluid restriction; surgical ligation);

5. interventions for neonates with respiratory disorders, such as apnoea of prematurity (e.g. kinaesthetic stimulation; methylxanthines (caffeine)); respiratory distress syndrome (e.g. early or delayed, prophylactic or selective, protein-containing or protein-free, animal-derived or synthetic pulmonary surfactant; thyroid hormones; continuous distending pressure); or bronchopulmonary dysplasia (chronic lung disease) (e.g. early or late, inhaled or systemic, postnatal corticosteroids);

6. interventions for gastrointestinal tract disorders, such as necrotising enterocolitis (e.g. lactoferrin; probiotics; antibiotics; immunoglobulin; peritoneal drainage; laparotomy);

7. interventions for neonates with infection, such as for control of general infection (e.g. chlorhexidine skin or cord care; patient isolation for infection; gowning by attendants and visitors in newborn nurseries); fungal and protozoal infections (e.g. prophylactic antifungal agents; antifungal therapy for invasive fungal infection); viral infections (e.g. antiviral agents for treatment of herpes simplex virus or cytomegalovirus infection); or bacterial infections (e.g. intravenous immunoglobulin for prevention of infection, or for suspected or proven infection; antibiotics for suspected early- or late-onset sepsis; intraventricular antibiotics for meningitis; prophylactic antibiotics for ventilated newborns);

8. interventions for neonates with metabolic or endocrine disorders, such as disorders of carbohydrate metabolism (e.g. oral dextrose gel for hypoglycaemia; insulin for hyperglycaemia) or thyroid disorders (postnatal thyroid hormones);

9. interventions for neonates with jaundice and liver disorders (e.g. phototherapy);

10.interventions focused on nutrition or metabolism for highrisk neonates (i.e. preterm or low birthweight neonates, or both) including enteral nutrition interventions (e.g. high protein intake; donor breast milk; nutrient-enriched formula; multinutrient fortification of human breast milk; responsive or scheduled feeding), parenteral nutrition interventions (e.g. early or late, high or low amino acid administration), or vitamin or mineral supplementation (e.g. glutamine; arginine; iodine; vitamin E);

11.interventions for neurodevelopmental care or physical environment management (or both) for neonates (e.g. developmental care to reduce stressors in the neonatal nursery; kangaroo mother care; massage; co-bedding in the neonatal nursery; early developmental programmes post discharge to prevent motor and cognitive impairments); and

12.interventions for all neonates at birth, such as newborn screening for inborn errors of metabolism.

We will not consider interventions in the antenatal or intrapartum period (such as magnesium sulphate for foetal neuroprotection (Doyle 2009)), as these interventions will be assessed in a separate overview (Shepherd 2016, under review).

\section{How the intervention might work}

Advances in research into several factors that modify the risk of cerebral palsy suggest many opportunities for prevention, with the main neonatal strategies focusing on protection of the immature brain through administration of neuroprotective agents or therapies.

For many individuals born at or near term who develop cerebral palsy, their neonatal course has been seemingly unremarkable, with the exception of those following perinatal asphyxia and with neonatal encephalopathy (brain injury that may be due to cerebral hypoxia and ischaemia before birth) (Badawi 2005; O'Shea 2008). For these neonates, therapeutic hypothermia, applied selectively to the head (as a 'cooling cap') or to the whole body, is one such intervention that can mediate cerebral palsy risk (O'Shea 2008). Beyond cooling, a range of other interventions (including those used as adjuvant therapy with cooling) may contribute to cerebral palsy prevention by protecting against secondary cell death and brain damage following hypoxic-ischaemic insult (Robertson 2012), or by treating the underlying cause(s) of encephalopathy (such as infection or metabolic derangement).

For preterm and very low birthweight neonates, and for other groups of neonates (such as those with hypoglycaemia) who are 
at increased risk of brain injury, many pharmacological and nonpharmacological interventions in the neonatal period may mediate cerebral palsy risk (O'Shea 2008). Although these interventions differ in their primary aims (such as maintaining adequate ventilation (e.g. through treatment of apnoea of prematurity with caffeine); maintaining normal metabolic status (e.g. through treatment of neonatal hypoglycaemia with dextrose gel); or controlling neonatal seizures (e.g. through use of anticonvulsants)), each may contribute to cerebral palsy prevention by reducing the likelihood or severity of brain injury, and thus of long-term neurodevelopmental sequelae.

\section{Why it is important to do this overview}

A multitude of individual studies and Cochrane Systematic Reviews assessing a broad range of neonatal interventions (with varying primary aims or indications) acknowledge the potential for the intervention of interest to influence cerebral palsy risk. With awareness that there are many and varied risk factors for cerebral palsy, and that causes of cerebral palsy differ, there is a need to systematically consider all potentially relevant interventions for their ability to contribute to reducing cerebral palsy risk. As new data suggest possible declining rates and severity of cerebral palsy, it is important to examine the different interventions that may, together, contribute to these observations.

To our knowledge, to date, no 'overview' has brought together the evidence around neonatal interventions for cerebral palsy prevention from Cochrane Systematic Reviews into a single coherent document to be used by researchers, funding bodies, policy makers, clinicians, and consumers to aid decision-making and evidence implementation.

Although the objective of this overview is to summarise the evidence from Cochrane Systematic Reviews regarding effects of neonatal interventions for preventing cerebral palsy, it is also important to consider whether such interventions may, instead, actually contribute to increasing cerebral palsy risk.

\section{Is an overview the right approach?}

We have followed the Editorial Decision Tree proposed by the Cochrane Comparing Multiple Interventions Methods Group to establish whether our review would better fit an overview format or an intervention review format, specifically:

1. we will review systematic reviews, instead of individual trials;

2. we will not compare multiple interventions with the intention of drawing inferences about the comparative effectiveness of these interventions; and

3. we intend to present a map of evidence from systematic reviews but with no attempt to rank the interventions.

On the basis of these points, the Editorial Decision Tree recommends an overview as the appropriate format for this review.

\section{O B J E C T IVES}

\section{Primary}

To summarise the evidence from Cochrane Systematic Reviews regarding effects of neonatal interventions for preventing cerebral palsy (reducing cerebral palsy risk).

\section{Secondary}

To summarise the evidence from Cochrane Systematic Reviews regarding effects of neonatal interventions that may increase cerebral palsy risk.

\section{METHODS}

\section{Criteria for considering reviews for inclusion}

In this overview of systematic reviews, we included only published Cochrane Systematic Reviews of neonatal interventions for which cerebral palsy was reported as a primary or secondary review outcome. We identified Cochrane protocols and titles for future inclusion and classified them as 'Ongoing reviews' (in an Appendix).

We made note of publication and search dates of the reviews; however, we did not attempt to update the individual systematic reviews.

\section{Participants}

We considered reviews that included:

1. neonates with perinatal asphyxia or with evidence of neonatal encephalopathy; and

2. neonates born preterm or at low or very low birthweight (or both preterm and low/very low birthweight neonates).

We also included reviews that included other groups of 'at risk' neonates (e.g. neonates with hypoglycaemia), so long as the intervention assessed in the Cochrane Systematic Review was recognised by the review authors as having the potential to influence cerebral palsy risk - cerebral palsy had to be pre-specified as a primary or secondary outcome in the review.

\section{Interventions}

We considered all types of interventions used in the neonatal period compared with placebo, no treatment, or an alternative intervention.

We included both pharmacological and non-pharmacological interventions (see Description of the interventions for further description of possible interventions).

\section{Outcomes of interest}

\section{Primary}

1. Cerebral palsy (regardless of criteria used for diagnosis by review authors or trialists, and regardless of age at diagnosis; however, we have reported any variation)

\section{Secondary}

1. Cerebral palsy or death (regardless of criteria used for diagnosis by review authors or trialists, and regardless of age at diagnosis; however, we have reported any variation)

2. Severity of cerebral palsy (e.g. according to Gross Motor Function Classification System (GMFCS); Manual Ability Classification System (MACS); Communication Function Classification System (CFCS))

3. Type of cerebral palsy (e.g. according to topography (diplegia; hemiplegia; quadriplegia; monoplegia; triplegia) or motor type (spastic; dyskinetic; ataxic)) 
4. Motor dysfunction (regardless of criteria used for diagnosis by review authors or trialists, and regardless of age at diagnosis; however, we have reported any variation)

5. Other composite outcomes that include cerebral palsy as a component (regardless of criteria used for diagnosis by review authors or trialists, and regardless of age at diagnosis; however, we have reported any variation)

To be included, a review had to pre-specify our overview's primary outcome - cerebral palsy (or a composite outcome that included cerebral palsy ${ }^{\star}$ ) as a primary or secondary systematic review outcome - and must have reported data for this outcome from at least one of the included trials in the review.

We listed reviews that pre-specified cerebral palsy as a primary or secondary systematic review outcome but provided no reported data from included trials on this outcome as 'Reviews awaiting further classification', and we will reconsider these reviews in future updates of the overview.

* When possible, we extracted data related to cerebral palsy from any composite outcomes that included cerebral palsy. When it was not possible to extract only cerebral palsy data from such composite outcomes, we reported the composite outcome data; however, we reported these separately from the data for our primary outcome (i.e. as a secondary outcome).

\section{Search methods for identification of reviews}

We searched the Cochrane Database of Systematic Reviews on 27 November 2016, using the term 'cerebral palsy'. We used the search term to search 'all text', not limited to 'title, abstract, or keywords'. We did not apply any language or date restrictions. We searched no other databases. We managed citations retrieved through the search by using Covidence (Covidence 2015).

\section{Data collection and analysis}

We based our data collection and synthesis methods on Chapter 22 of the Cochrane Handbook for Systematic Reviews of Interventions (Higgins 2011). When appropriate, we prepared the overview using Covidence (Covidence 2015) and Review Manager 5 software (RevMan 2014).

\section{Selection of reviews}

Two overview authors independently assessed for inclusion all potential systematic reviews identified by the search. We resolved disagreements through discussion, or, if required, we consulted a third member of the overview team.

\section{Data extraction and management}

Two overview authors independently extracted data from the reviews using a pre-defined data extraction form. We resolved discrepancies through discussion or, if needed, through consultation with a third overview author. When information regarding review outcomes was unclear or missing, we accessed the published papers of individual studies for further details.

We extracted information on the following.
1. Review characteristics.

a. Review title and authors.

b. Date that the review was last assessed as up-to-date.

c. Number of included trials and numbers of participants (neonates) in the trials and their characteristics (e.g. countries in which the trials were conducted, trial inclusion criteria).

d. Quality of the included trials (as reported by the review authors; see 'Quality of studies included within reviews' below under Assessment of methodological quality of included reviews).

e. Interventions and comparisons relevant to this overview.

f. All pre-specified outcomes relevant to this overview (their definitions, and whether they were primary or secondary outcomes in the included reviews).

g. Any other characteristics required to assess and report on review quality (see 'Quality of included reviews' under Assessment of methodological quality of included reviews).

2. Statistical summaries*.

a. Summary intervention effects (including pooled effects (e.g. risk ratios (RRs), odds ratios (ORs), or mean differences (MDs) as reported in the individual reviews), 95\% confidence intervals (Cls), and numbers of studies and participants contributing data to each pooled effect) from comparisons and for outcomes relevant to this overview.

b. Information required to assess and report on the quality of evidence for the intervention effects extracted above (see 'Quality of evidence in included reviews' under Assessment of methodological quality of included reviews).

* When review authors were not able to perform meta-analyses and therefore did not report statistical summaries, we extracted from those reviews the narrative text related to results for our overview outcomes.

\section{Assessment of methodological quality of included reviews Quality of included reviews}

We assessed the methodological quality of each systematic review using the AMSTAR (A Measurement Tool to Assess Systematic Reviews) instrument (Shea 2009). AMSTAR evaluates the methods used in a review against 11 distinct criteria and assesses the degree to which review methods are unbiased. Each item on AMSTAR is rated as 'yes' (clearly done), 'no' (clearly not done), 'cannot answer', or 'not applicable'. These criteria were as follows:

1. Was an 'a priori' design provided?

2. Was there duplicate study selection and data extraction?

3. Was a comprehensive literature search performed?

4. Was status of the publication used as an inclusion criterion?

5. Was a list of studies (included and excluded) provided?

6. Were the characteristics of included studies provided?

7. Was the scientific quality of included studies assessed and documented?

8. Was the scientific quality of included studies used appropriately in formulating conclusions?

9. Were the methods used to combine the findings of studies appropriate?

10.Was the likelihood of publication bias assessed? 


\section{Was conflict of interest stated?}

For all items except item 4, we considered a rating of 'yes' as adequate. For item 4, we considered a rating of 'no' as adequate. We considered a review that adequately met all of the 11 criteria to be a review of the highest quality (Shea 2009). For this overview, we considered reviews that achieved scores of 8 to 11 as high quality; scores of 4 to 7 as medium quality; and scores of 0 to 3 as low quality.

To further assess risk of bias of the systematic reviews, we additionally used the new ROBIS (Risk of Bias in Systematic Reviews) tool (Whiting 2015). This tool considers risk of bias across four key domains.

1. Study eligibility criteria.

2. Identification and selection of studies.

3. Data collection and study appraisal.

4. Synthesis and findings.

A series of questions within each domain elicited information about possible limitations of the systematic review, leading to a judgement about concerns within that domain (low, high, or unclear). We then considered risk of bias of the review as a whole, using signalling questions and information to support the overall judgement of risk of bias (low, high, or unclear) (Whiting 2015).

Two overview authors independently assessed the quality of included reviews using AMSTAR and ROBIS, and another overview author verified this assessment. We resolved differences through discussion or, if needed, through consultation with a third overview author.

We also noted and reported for each review the publication and search dates.

\section{Quality of studies included within reviews}

We did not reassess the quality of studies included within reviews but instead reported study quality according to review authors' assessments. We collected this information during the data extraction process.

\section{Quality of evidence in included reviews}

We assessed/reported the quality of evidence for our primary outcome (cerebral palsy) and for secondary review outcomes using the GRADE approach, as outlined in the GRADE handbook. We reported the quality of evidence as assessed by systematic review authors (who were in the best position to assess quality, given their familiarity with study-level data) by using GRADEPro 'Summary of findings' tables from the reviews if provided (or when necessary, we constructed such tables using the GRADEpro Guideline Development Tool). The GRADE system assesses the following features for the evidence found for important outcomes.

1. Study limitations (risk of bias): internal validity of the evidence.

2. Inconsistency: heterogeneity or variability in estimates of effect across studies.

3. Indirectness: degrees of difference between populations, interventions, and comparators for the intervention and the outcome of interest.
4. Imprecision (random error): extent to which confidence in the effect estimate is adequate to support a particular decision.

5. Publication bias: degree of selective publication of studies.

The GRADE system rates the quality of evidence as follows.

1. High (further research is very unlikely to change confidence in the estimate of effect).

2. Moderate (further research is likely to have an important impact on confidence in the estimate of effect and may change the estimate).

3. Low (further research is very likely to have an important impact on confidence in the estimate of effect and is likely to change the estimate).

4. Very low (any estimate of effect is very uncertain).

\section{Data synthesis}

We prepared a narrative description of characteristics of the included Cochrane Reviews. We organised Review findings by groups of neonates when possible as follows: interventions for neonates with perinatal asphyxia or with evidence of neonatal encephalopathy; interventions for neonates born preterm and at low or very low birthweight; and interventions for other specific groups of 'at risk' neonates.

We summarised the main results of included reviews by categorising their findings in the following framework (as has been used within previous Cochrane and non-Cochrane overviews, such as Farquhar 2015 and Lassi 2015).

1. Effective interventions: indicating that the review found highquality evidence of effectiveness for an intervention.

2. Possibly effective interventions (more evidence needed): indicating that the review found moderate-quality evidence of effectiveness for an intervention, but more evidence is needed.

3. Ineffective interventions: indicating that the review found highquality evidence of lack of effectiveness for an intervention.

4. Probably ineffective interventions (more evidence needed): indicating that the review found moderate-quality evidence suggesting lack of effectiveness for an intervention, but more evidence is needed.

5. No conclusions possible: indicating that the review found low- or very low-quality evidence, or insufficient evidence to comment on the effectiveness of an intervention.

We based the choice of category on quality of evidence for the primary overview outcome (cerebral palsy). We used separate assessments for different comparisons (e.g. when one intervention was compared both with placebo (or no treatment) and with an alternative intervention). This approach to summarising the evidence was based on an earlier Cochrane overview (Jones 2012), which categorised interventions as 'What works,' 'What may work', and 'Insufficient evidence to make a judgement'.

\section{RE S U L T S}

Our search of the Cochrane Database of Systematic Reviews yielded 513 protocols and reviews. Following title and abstract review, we excluded 303 protocols or reviews and assessed the full text of 210 protocols or reviews. 
We excluded 25 reviews that did not pre-specify cerebral palsy as a primary or secondary review outcome (see Table 1, 'Characteristics of excluded studies').

We listed an additional 142 protocols and reviews in the Appendices.

1. Appendix 1 ('Ongoing reviews') lists 40 Cochrane protocols that pre-specified cerebral palsy as a primary or secondary outcome; we will consider these protocols for inclusion in future updates of the overview when they have been published as full reviews.

2. Appendix 2 ('Reviews awaiting further classification') summarises the 102 Cochrane Reviews that pre-specified cerebral palsy as a primary or secondary outcome but reported no data from included trials on this outcome; again, we will consider these reviews for inclusion in future updates of the overview.

We therefore included 43 reviews in this overview. See Figure 1. 
Figure 1. Study flow diagram.

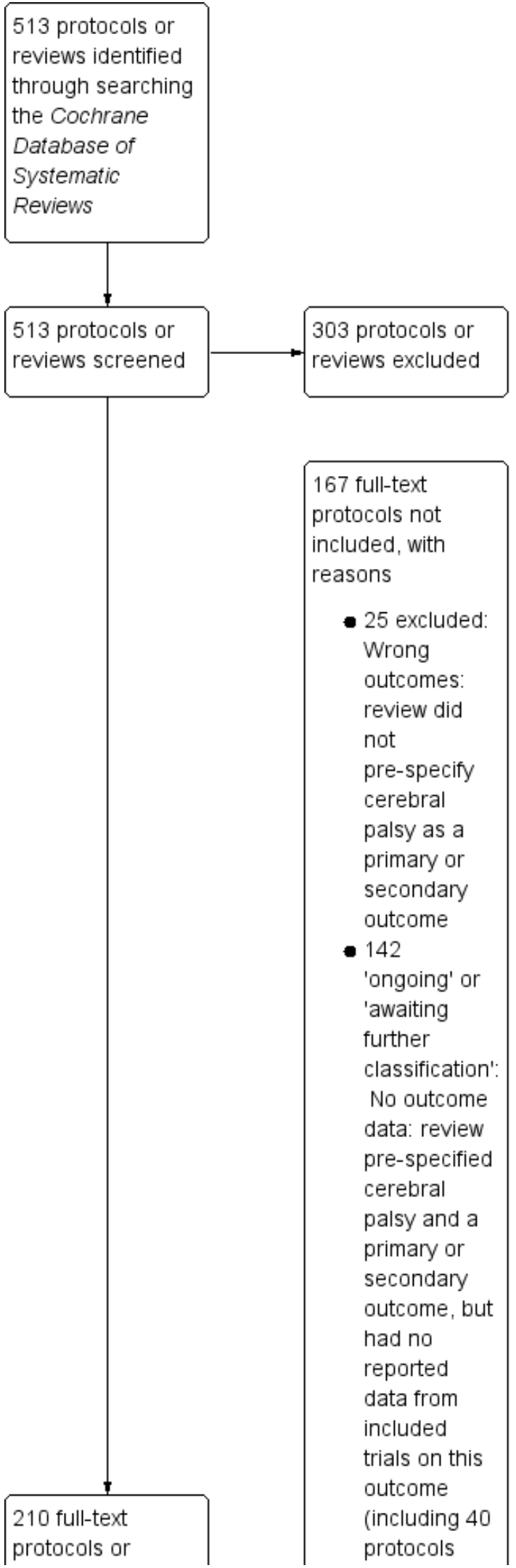


Figure 1. (Continued)

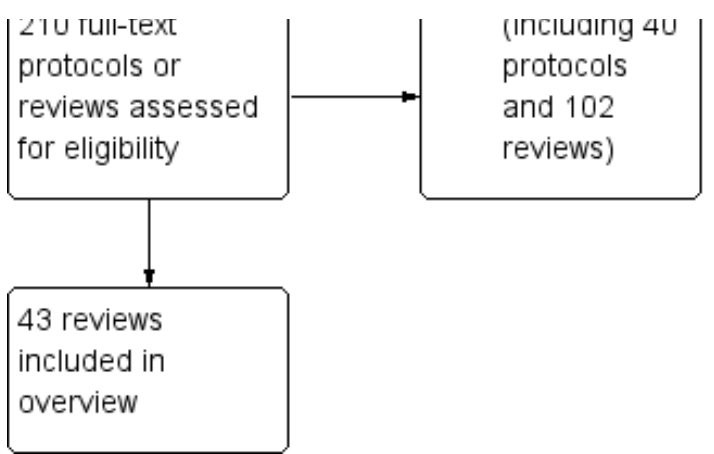

\section{Description of included reviews}

Of the 43 included reviews:

1. Three reviews focused on interventions for neonates with perinatal asphyxia or with evidence of neonatal encephalopathy, categorised under the Cochrane Neonatal 'Neonatal care' topic.

a. Asphyxia: 'Allopurinol for preventing mortality and morbidity in newborn infants with hypoxic-ischaemic encephalopathy' (Chaudhari 2012); 'Cooling for newborns with hypoxic ischaemic encephalopathy' (Jacobs 2013); 'Prophylactic barbiturate use for the prevention of morbidity and mortality following perinatal asphyxia' (Young 2016).

2. Thirty-three reviews focused on interventions for neonates born preterm and/or at low or very low birthweight, categorised under the following Cochrane Neonatal 'Neonatal care' topics.

a. Haemorrhage: periventricular/intraventricular: 'Ethamsylate for the prevention of morbidity and mortality in preterm or very low birth weight infants' (Hunt 2010); 'Postnatal phenobarbital for the prevention of intraventricular haemorrhage in preterm infants' (Smit 2013).

b. Hypotension: 'The effect of inotropes on morbidity and mortality in preterm infants with low systemic or organ blood flow' (Osborn 2007b).

c. Fluid therapy: 'Early volume expansion for prevention of morbidity and mortality in very preterm infants' (Osborn 2004).

d. Patent ductus arteriosus: 'Prophylactic intravenous indomethacin for preventing mortality and morbidity in preterm infants' (Fowlie 2010); 'Ibuprofen for the treatment of patent ductus arteriosus in preterm or low birth weight (or both) infants' (Ohlsson 2015).

e. Blood disorders: 'Early erythropoietin for preventing red blood cell transfusion in preterm and/or low birth weight infants' (Ohlsson 2014); 'Low versus high haemoglobin concentration threshold for blood transfusion for preventing morbidity and mortality in very low birth weight infants' (Whyte 2011).

f. Nitric oxide: 'Inhaled nitric oxide for respiratory failure in preterm infants' (Barrington 2010).

g. Apneoa: 'Methylxanthine treatment for apnoea in preterm infants' (Henderson-Smart 2010b); 'Prophylactic methylxanthine for prevention of apnoea in preterm infants' (Henderson-Smart 2010c). h. Respiratory distress syndrome: 'Inositol in preterm infants at risk for or having respiratory distress syndrome' (Howlett 2015); 'Animal derived surfactant extract for treatment of respiratory distress syndrome' (Seger 2009); 'Synthetic surfactant for respiratory distress syndrome in preterm infants' (Soll 2000); 'Prophylactic protein free synthetic surfactant for preventing morbidity and mortality in preterm infants' (Soll 2010).

i. Mechanical ventilation: 'Elective high frequency oscillatory ventilation versus conventional ventilation for acute pulmonary dysfunction in preterm infants' (Cools 2015); 'Continuous distending pressure for respiratory distress in preterm infants' (Ho 2015); 'Prophylactic methylxanthines for endotracheal extubation in preterm infants' (HendersonSmart 2010).

j. Bronchopulmonary dysplasia: 'Early ( $<8$ days) postnatal corticosteroids for preventing chronic lung disease in preterm infants' (Doyle 2014b); 'Moderately early (7 to 14 days) postnatal corticosteroids for preventing chronic lung disease in preterm infants' (Halliday 2003); 'Late (> 7 days) postnatal corticosteroids for chronic lung disease in preterm infants' (Doyle 2014); 'Early administration of inhaled corticosteroids for preventing chronic lung disease in ventilated very low birth weight preterm neonates' (Shah 2012); 'Vitamin A supplementation to prevent mortality and short- and long-term morbidity in very low birth weight infants' (Darlow 2016).

k. Necrotising enterocolitis: 'Probiotics for prevention of necrotizing enterocolitis in preterm infants' (AlFaleh 2014); 'Arginine supplementation for prevention of necrotising enterocolitis in preterm infants' (Shah 2007).

l. Fungal infections: 'Prophylactic systemic antifungal agents to prevent mortality and morbidity in very low birth weight infants' (Cleminson 2015).

m. Jaundice: 'Prophylactic phototherapy for preventing jaundice in preterm or low birth weight infants' (Okwundu 2012).

n. Parenteral feeding: 'Glutamine supplementation to prevent morbidity and mortality in preterm infants' (Moe-Byrne 2016).

o. Other neonatal care (including thermal environment and developmental care): 'Thyroid hormones for preventing neurodevelopmental impairment in preterm infants' (Osborn 2001); 'Prophylactic postnatal thyroid hormones for prevention of morbidity and mortality in preterm infants' (Osborn 2007); 'Sound reduction management in 
the neonatal intensive care unit for preterm or very low birth weight infants' (Almadhoob 2015); 'Kangaroo mother care to reduce morbidity and mortality in low birthweight infants' (Conde-Agudelo 2016); 'Early developmental intervention programmes provided post hospital discharge to prevent motor and cognitive impairment in preterm infants' (Spittle 2015).

3. Seven reviews focused on interventions for other specific groups of 'at risk' neonates, categorised under the following Cochrane Neonatal 'Neonatal care' topics.

a. Pulmonary hypertension: 'Endothelin receptor antagonists for persistent pulmonary hypertension in term and late preterm infants' (More 2016).

b. Resuscitation: 'Air versus oxygen for resuscitation of infants at birth' (Tan 2005).

c. Nitric oxide: 'Nitric oxide for respiratory failure in infants born at or near term' (Finer 2006).

d. Mechanical ventilation: 'Long versus short inspiratory times in neonates receiving mechanical ventilation' (Kamlin 2003); 'Volume-targeted versus pressure-limited ventilation in the neonate' (Wheeler 2010) (although in these reviews, relevant outcome data were from neonates born preterm and/or at low or very low birthweight only).

e. Herpes simplex: 'Antiviral agents for treatment of herpes simplex virus infection in neonates' (Jones 2009).

f. Hypoglycaemia: 'Oral dextrose gel for the treatment of hypoglycaemia in newborn infants' (Weston 2016).

The 43 reviews included between one - as in Almadhoob 2015, Osborn 2007b, and Shah 2007 - and 33 - as in Ohlsson 2015 randomised controlled trials, and between 34 - as in Almadhoob 2015 - and 5529 - as in AlFaleh 2014 - infants. In total, the 43 reviews included 454 randomised trials, involving 63,977 infants.

One-third (14) of the 43 reviews had conducted searches (and were considered 'up-to-date') in the past three years (November 2013 to November 2016) (AlFaleh 2014; Almadhoob 2015; Cleminson 2015; Conde-Agudelo 2016; Cools 2015; Darlow 2016; Ho 2015; Howlett 2015; Moe-Byrne 2016; More 2016; Ohlsson 2015; Spittle 2015; Weston 2016; Young 2016). The other 29 reviews had latest search end dates ranging from May 1998 - in Soll 2000 - to August 2013 - in Doyle 2014b.

See Table 2 and Table 3 for further details of the characteristics of the 43 included reviews (including review IDs and titles, search dates and when the review was last assessed as up-to-date, numbers of randomised controlled trials and infants included, interventions and comparisons examined, overview outcomes reported, and summary of included trial limitations (risk of bias)).

\section{Methodological quality of included reviews}

We rated the quality of included reviews using the AMSTAR and ROBIS tools (Shea 2009 and Whiting 2015, respectively).

With regards to AMSTAR criteria:

1. 41/43 reviews clearly pre-specified their design; for two reviews, this was unclear, with no reference made/access given to prespecified published protocols (Seger 2009; Soll 2000);

2. 40/43 reviews clearly reported duplicate study selection and data extraction; for three reviews, it was unclear as to whether two independent review authors were involved in study selection and data extraction (Halliday 2003; Osborn 2001; Soll 2000);

3. $42 / 43$ reviews performed a comprehensive literature search; one review searched only one electronic database (in addition to electronic searching and handsearching of meeting abstracts) (Finer 2006);

4. all reviews considered grey literature;

5. 41/43 reviews provided lists of both included and excluded studies; two reviews did not mention excluded studies and therefore provided no list (Henderson-Smart 2010; Shah 2007);

6. all reviews provided the characteristics of included studies;

7. all reviews assessed and documented the scientific quality of included studies;

8. 42/43 reviews clearly used scientific quality of included studies appropriately in formulating conclusions; one review did not clearly incorporate the quality of included studies into the conclusions (Barrington 2010);

9. 35/38 reviews combined the findings of studies using appropriate methods; three reviews provided no/limited discussion and/or exploration of substantial statistical heterogeneity present in some review meta-analyses and did not use a random-effects model (Halliday 2003; Okwundu 2012; Soll 2000); for five reviews, review authors found this item to be 'not applicable' and conducted no meta-analyses (Almadhoob 2015; Jones 2009; More 2016; Osborn 2007b; Shah 2007);

10.18/43 reviews assessed the likelihood of publication bias; 25 reviews did not assess publication bias likelihood and/or did not pre-specify methods to be used if 10 or more trials were included in meta-analyses (AlFaleh 2014; Barrington 2010; Cools 2015; Finer 2006; Fowlie 2010; Halliday 2003; Henderson-Smart 2010; Henderson-Smart 2010b; Henderson-Smart 2010c; Ho 2015; Hunt 2010; Jacobs 2013; Jones 2009; Kamlin 2003; Okwundu 2012; Osborn 2001; Osborn 2004; Osborn 2007; Seger 2009; Shah 2007; Soll 2000; Soll 2010; Spittle 2015; Tan 2005; Wheeler 2010);

11.2/43 reviews clearly reported conflicts of interest/potential sources of support for both the review and the included studies (Jacobs 2013; Weston 2016); the remaining 41 reviews did not report conflicts of interests/sources of support for the included studies (AlFaleh 2014; Almadhoob 2015; Barrington 2010; Chaudhari 2012; Cleminson 2015; Conde-Agudelo 2016; Cools 2015; Darlow 2016; Doyle 2014; Doyle 2014b; Finer 2006; Fowlie 2010; Halliday 2003; Henderson-Smart 2010; HendersonSmart 2010b; Henderson-Smart 2010c; Ho 2015; Howlett 2015; Hunt 2010; Jones 2009; Kamlin 2003; Moe-Byrne 2016; More 2016; Ohlsson 2014; Ohlsson 2015; Okwundu 2012; Osborn 2001; Osborn 2004; Osborn 2007; Osborn 2007b; Seger 2009; Shah 2007; Shah 2012; Smit 2013; Soll 2000; Soll 2010; Spittle 2015; Tan 2005; Wheeler 2010; Whyte 2011; Young 2016).

See Table 4 for further details.

\section{With regards to ROBIS domains:}

1. 40 reviews were considered to have 'low risk of bias' across study eligibility criteria, data collection and study appraisal, and synthesis and findings domains, and 39 were considered to have 'low risk of bias' for the identification and selection of studies domain; 
2. three reviews were considered to have 'unclear risk of bias' for the study eligibility criteria domain; as above, two reviews provided no reference/access to pre-specified published protocols (Seger 2009; Soll 2000); and one review made a notable protocol deviation related to the inclusion criteria (Almadhoob 2015);

3. three reviews were considered to have 'unclear risk of bias' for both the identification and selection of studies domain and the data collection and study appraisal domain because review authors did not clearly specify whether two independent review authors were involved in selection of studies, data collection, and study appraisal (Halliday 2003; Osborn 2001; Soll 2000); one further review was considered to have 'unclear risk of bias' for the identification and selection of studies domain, as above, owing to concern regarding comprehensiveness of the search (Finer 2006); and

4. finally, three reviews were considered to have 'unclear risk of bias' for the synthesis and findings domain owing to the presence of substantial statistical heterogeneity (with use of a fixed-effect model) in some review meta-analyses that was not clearly explained/explored (Halliday 2003; Okwundu 2012; Soll 2000).

\section{See Table 5 for additional details.}

Overall, all 41 included reviews were judged to be of 'high quality' according to AMSTAR (with scores ranging from 8 to 11 out of 11 , or from 7 to 9 out of 10), and two were judged to be of 'moderate quality' (with scores of 6 and 7 out of 11) (Halliday 2003; Soll 2000); according to ROBIS, 40 reviews were judged to have 'low risk of bias', and three to have 'unclear risk of bias' (Finer 2006; Osborn 2001; Soll 2000).

\section{Effect of interventions}

Below, we have summarised the main results of the included reviews by categorising their findings according to the framework discussed under Data synthesis, organised by groups of neonates and 'Neonatal care' topics.

For further details, including outcome definitions and judgements supporting the quality of the evidence for each outcome, see Table 6 (cerebral palsy); Table 7 (cerebral palsy: subgroup or sensitivity analyses); Table 8 (cerebral palsy or death); Table 9 (severity of cerebral palsy); Table 10 (other composite outcomes that include cerebral palsy); and Table 11 (motor dysfunction).

\section{Interventions for neonates with perinatal asphyxia or evidence of neonatal encephalopathy}

\section{Effective interventions: high-quality evidence of effectiveness}

\section{Neonatal care: treating asphyxia}

High-quality evidence from the Jacobs 2013 review showed a reduction in cerebral palsy among survivors assessed at 18 to 24 months following therapeutic hypothermia versus standard care for newborns with hypoxic-ischaemic encephalopathy (risk ratio (RR) $0.66,95 \%$ confidence interval (Cl) 0.54 to 0.82 ; seven trials; 881 children) (Table 6). Subgroup analysis based on method of cooling (e.g. selective head cooling with mild hypothermia, whole body cooling) showed no clear subgroup differences $\left(\mathrm{Chi}^{2}=0.01, \mathrm{df}=1(\mathrm{P}\right.$ $=0.93), \mathrm{I}^{2}=0.0 \%$ ) (Table 7). Low-quality evidence from Jacobs 2013 also showed no clear differences for cerebral palsy at six to seven years following therapeutic hypothermia versus standard care (RR $0.60,95 \% \mathrm{Cl} 0.31$ to 1.18 ; one trial; 121 children) (Table 6). Highquality evidence from Jacobs 2013 showed reductions in death or major disability among survivors assessed at 18 to 24 months (RR $0.75,95 \% \mathrm{Cl} 0.68$ to 0.83 ; eight trials; 1344 children), major neurodevelopmental disability at 18 to 24 months (RR $0.77,95 \% \mathrm{Cl}$ 0.63 to 0.94 ; eight trials; 1344 children), major neurodevelopmental disability among survivors assessed at 18 to 24 months (RR 0.67 , $95 \% \mathrm{Cl} 0.55$ to 0.80 ; eight trials; 917 children), and neuromotor delay among survivors assessed at 18 to 24 months (RR $0.75,95 \% \mathrm{Cl}$ 0.59 to 0.94 ; six trials; 657 children) (Table 10 ; Table 11). Low-quality evidence suggested no clear differences for death or moderate to severe disability at six to seven years (RR $0.81,95 \% \mathrm{Cl} 0.64$ to 1.04 ; one trial; 190 children) nor for moderate to severe disability at six to seven years (RR $0.92,95 \% \mathrm{Cl} 0.57$ to 1.48 ; one trial; 119 children) following therapeutic hypothermia versus standard care (Table 10).

\section{No conclusions possible: very low-quality evidence}

\section{Neonatal care: treating asphyxia}

Very low-quality evidence from the Young 2016 review suggested no clear differences for cerebral palsy at three to six years with barbiturates (phenobarbital) versus conventional therapy for prevention of morbidity and mortality following perinatal asphyxia (RR $0.58,95 \% \mathrm{Cl} 0.19$ to 1.70 ; two trials; 69 children) (Table 6). Very low-quality evidence from Young 2016 also suggested a reduction in death or major neurodevelopmental disability at three years (RR $0.33,95 \% \mathrm{Cl} 0.14$ to 0.78 ; one trial; 31 children) and in major neurodevelopmental disability at three years (RR 0.24 , $95 \% \mathrm{Cl} 0.06$ to 0.92 ; one trial; 31 children) following barbiturates (phenobarbital) versus conventional therapy (Table 10).

Very low-quality evidence from the Chaudhari 2012 review suggested no clear differences for severe quadriplegia among survivors at 18 months or at four to eight years following allopurinol versus placebo or no drug for preventing mortality and morbidity among newborn infants with hypoxic-ischaemic encephalopathy (RR $0.59,95 \% \mathrm{Cl} 0.28$ to 1.27 ; three trials; 73 children) (Table 9). Very low-quality evidence from Chaudhari 2012 also suggested no clear differences for death or severe neurodevelopmental disability among survivors at 18 months or at four to eight years following allopurinol versus placebo ( $\mathrm{RR} 0.78,95 \% \mathrm{Cl} 0.56$ to 1.08 ; three trials; 110 children) (Table 10).

\section{Interventions for neonates born preterm and/or at low or very low birthweight}

\section{Possibly effective interventions: moderate-quality evidence of effectiveness}

\section{Neonatal care: mechanical ventilation}

Moderate-quality evidence from the Henderson-Smart 2010 review showed a reduction in cerebral palsy at 18 to 21 months' corrected age with prophylactic methylxanthines (caffeine) versus placebo for endotracheal extubation in preterm infants (RR $0.54,95 \% \mathrm{Cl} 0.32$ to 0.92 ; one trial; 644 children) (Table 6). Moderate-quality evidence from Henderson-Smart 2010 also showed a reduction in death or major disability at 18 to 21 months' corrected age with prophylactic methylxanthines (caffeine) versus placebo (RR $0.85,95 \% \mathrm{Cl} 0.73$ to 0.99; one trial; 676 children) (Table 10). 
Probably ineffective interventions: moderate-quality evidence of harm

\section{Neonatal care: preventing bronchopulmonary dysplasia}

Moderate-quality evidence from the Doyle 2014b review showed an increase in cerebral palsy at 11 months to seven to nine years (RR $1.45,95 \% \mathrm{Cl} 1.06$ to $1.98 ; 12$ trials; 1452 children) and in cerebral palsy among survivors assessed at 11 months to seven to nine years (RR $1.50,95 \% \mathrm{Cl} 1.13$ to $2.00 ; 12$ trials; 959 children) following early (less than eight days of age) postnatal corticosteroids versus placebo or no treatment for preventing chronic lung disease in preterm infants (Table 6). Subgroup analysis based on type of corticosteroid used (i.e. dexamethasone, hydrocortisone) suggested no clear subgroup differences for cerebral palsy at 11 months to seven to nine years $\left(\mathrm{Chi}^{2}=2.96, \mathrm{df}=1(\mathrm{P}=0.09), \mathrm{I}^{2}=\right.$ $66 \%)$; however, a possible subgroup difference was identified that was based on the type of corticosteroid used for cerebral palsy among survivors assessed at 11 months to seven to nine years ( $\mathrm{Chi}^{2}$ $\left.=3.99, \mathrm{df}=1(\mathrm{P}=0.05), \mathrm{I}^{2}=75 \%\right)$, with an increase in risk specifically observed in the dexamethasone (not the hydrocortisone) subgroup (Table 7). Moderate-quality evidence from Doyle 2014b also showed no clear differences for cerebral palsy or death at 11 months to seven to nine years (RR 1.09, 95\% Cl 0.92 to $1.25 ; 12$ trials; 1452 children) (Table 8) nor for death or major neurosensory disability at 18 to 22 months to 53 months (RR $1.05,95 \% \mathrm{Cl} 0.93$ to 1.17 ; seven trials; 1233 children) (Table 10); Bayley Scales of Infant Development Psychomotor Developmental Index less than minus two standard deviations below the mean at 18 to 22 months or at 25 months (RR 1.17, $95 \% \mathrm{Cl} 0.85$ to 1.60; three trials; 842 children); or Bayley Scales of Infant Development Psychomotor Developmental Index less than minus two standard deviations below the mean among tested survivors at 18 to 22 months or at 25 months (RR 1.17 , $95 \% \mathrm{Cl} 0.87$ to 1.57 ; three trials; 528 children) with early postnatal corticosteroids versus placebo or no treatment (Table 11). Lowquality evidence from Doyle 2014b suggested no clear differences between major neurosensory disability at 18 to 22 months to 53 months (RR 1.16, $95 \% \mathrm{Cl} 0.94$ to 1.43; seven trials; 1233 children) and major neurosensory disability among survivors examined at 18 to 22 months to 53 months (RR $1.14,95 \% \mathrm{Cl} 0.94$ to 1.38 ; seven trials; 799 children) with early postnatal corticosteroids versus placebo or no treatment (Table 10).

\section{Probably ineffective interventions: moderate-quality evidence of lack of effectiveness}

\section{Neonatal care: preventing haemorrhage: periventricular/} intraventricular

Moderate-quality evidence from the Hunt 2010 review showed no clear differences for cerebral palsy among surviving children available for follow-up at two years up to 3.5 to 4.2 years following ethamsylate versus placebo for prevention of morbidity and mortality in preterm or very low birthweight infants (RR 1.13, 95\% $\mathrm{Cl} 0.64$ to 2.00; three trials; 532 children) (Table 6), nor on further subgroup analysis of infants born at less than 31 completed weeks at less than 1500 grams (RR $0.82,95 \% \mathrm{Cl} 0.38$ to 1.75; two trials; 328 children) (Table 7). Moderate-quality evidence from Hunt 2010 also showed no clear differences for neurodevelopmental disability at two years of age among surviving children available for follow-up (RR $0.79,95 \% \mathrm{Cl} 0.53$ to 1.17; three trials; 532 children), and lowquality evidence suggested no clear differences for death or any disability by two years of age among children with known outcome at any point in time (RR $0.96,95 \% \mathrm{Cl} 0.82$ to 1.11 ; seven trials; 1334 children) following ethamsylate versus placebo (Table 10).

\section{Neonatal care: fluid therapy}

Moderate-quality evidence from the Osborn 2004 review showed no clear differences for cerebral palsy among survivors at two years following volume versus no treatment (RR $0.76,95 \% \mathrm{Cl} 0.48$ to 1.20 ; one trial; 604 children) and gelatin versus fresh frozen plasma (RR $0.94,95 \% \mathrm{Cl} 0.52$ to 1.69 ; one trial; 399 children) for prevention of morbidity and mortality in very preterm infants (Table 6). Formal subgroup analyses in Osborn 2004 were not applicable based on timing of treatment, types of infants enrolled, or methodological quality (with the one included trial for this outcome using early treatment (less than 24 hours of age) in unselected preterm infants (not selected on the basis of cardiovascular compromise) and providing complete follow-up for neurodevelopmental outcomes (RR $0.76,95 \% \mathrm{Cl} 0.48$ to 1.20 ; one trial; 604 children, as in main analysis)) (Table 7). Moderate-quality evidence from Osborn 2004 also showed no clear differences between volume versus no treatment for severe neurodevelopmental disability among survivors at two years (RR $0.80,95 \% \mathrm{Cl} 0.52$ to 1.23 ; one trial; 604 children) or for death or severe neurodevelopmental disability among survivors at two years (RR $1.00,95 \% \mathrm{Cl} 0.80$ to 1.24 ; one trial; 776 children); or between gelatin versus fresh frozen plasma for severe neurodevelopmental disability among survivors at two years (RR $0.99,95 \% \mathrm{Cl} 0.57$ to 1.72; one trial; 399 children) or for death or severe neurodevelopmental disability among survivors at two years (RR 1.11, 95\% Cl 0.86 to 1.43; one trial; 518 children) (Table 10).

\section{Neonatal care: preventing/treating patent ductus arteriosus}

Moderate-quality evidence from the Fowlie 2010 review showed no clear differences for cerebral palsy at 18 to 54 months (RR $1.04,95 \% \mathrm{Cl} 0.77$ to 1.40 ; four trials; 1372 children) or at eight years (RR 1.24, $95 \% \mathrm{Cl} 0.59$ to 2.62; one trial; 304 children) following prophylactic indomethacin versus placebo for preventing mortality and morbidity in preterm infants (Table 6). Moderatequality evidence from Fowlie 2010 also showed no clear differences for death or severe neurodevelopmental disability at 18 to 36 months following prophylactic indomethacin versus placebo (RR 1.02 , 95\% 0.90 to 1.15 ; three trials; 1491 children) (Table 10).

\section{Neonatal care: treating respiratory distress syndrome}

Moderate-quality evidence from the Soll 2000 review showed no clear differences in cerebral palsy among survivors examined at one year (RR 0.76, 95\% Cl 0.55 to 1.05; five trials; 1557 children) (Table 6) nor in moderate to severe cerebral palsy among survivors examined at one year following synthetic surfactant versus placebo for respiratory distress syndrome in preterm infants (RR 0.75, 95\% $\mathrm{Cl} 0.48$ to 1.16 ; five trials; 1557 children) (Table 9).

\section{Neonatal care: preventing jaundice}

Moderate-quality evidence from the Okwundu 2012 review showed no clear differences for cerebral palsy in all infants (birthweight < 2500 grams) at one year or at 18 months following prophylactic phototherapy versus standard care (starting phototherapy when serum bilirubin reached a pre-specified level) for preventing jaundice in preterm or low birthweight infants (RR 0.96, 95\% Cl 0.50 to 1.85 ; two trials; 756 children) (Table 6). Very low-quality evidence suggested no clear differences for cerebral palsy among all infants (birthweight $<1000$ grams) at 18 months (RR 0.29, 
95\% $\mathrm{Cl} 0.04$ to 2.27; one trial; 30 children) (Table 6). Okwundu 2012 reported in text that "Secondary reports emanating from Brown 1985 at six-year follow-up also showed that there was no significant difference in the rate of cerebral palsy between the phototherapy and control group" (not graded). Moderate-quality evidence from Okwundu 2012 did however show a reduction in neurodevelopmental impairment at 18 to 22 months following prophylactic phototherapy versus standard care (RR $0.85,95 \% \mathrm{Cl}$ 0.74 to 0.99 ; one trial; 1804 children) (Table 10).

\section{No conclusions possible: low-quality evidence}

\section{Neonatal care: preventing/treating blood disorders}

Low-quality evidence from Ohlsson 2014 suggested no clear differences for cerebral palsy at 18 to 22 months' corrected age in children examined following darbepoetin alfa versus placebo for preventing red blood cell transfusion in preterm and/or low birthweight infants (RR $0.08,95 \% \mathrm{Cl} 0.00$ to 1.40; one trial; 51 children) (Table 6).

Low-quality evidence from Whyte 2011 suggested no clear differences for cerebral palsy at 18 to 21 months' follow-up among survivors following transfusion at a restrictive (low haemoglobin) versus a liberal (high haemoglobin) threshold for preventing morbidity and mortality in very low birthweight infants (RR 1.29, $95 \% \mathrm{Cl} 0.55$ to 3.03; one trial; 335 children) (Table 6). Low-quality evidence from Whyte 2011 also suggested no clear differences for any neurosensory impairment at 18 to 21 months' follow-up among survivors (RR $1.31,95 \% \mathrm{Cl} 0.90$ to 1.90 ; one trial; 328 children) nor for death or severe morbidity at 18 to 21 months' follow-up (Mental Development Index component defined < 70) (RR 1.17, $95 \% \mathrm{Cl} 0.94$ to 1.47; one trial; 421 children); however, moderatequality evidence showed a possible increase in death or severe morbidity at 18 to 21 months' follow-up (Mental Development Index component defined < 85) (RR $1.21,95 \% \mathrm{Cl} 1.01$ to 1.44; one trial; 421 children) with transfusion at a restrictive (low haemoglobin) versus a liberal (high haemoglobin) threshold (Table 10).

\section{Neonatal care: nitric oxide}

Low-quality evidence from Barrington 2010 suggested no clear differences following inhaled nitric oxide versus placebo or no treatment for respiratory failure in preterm infants for cerebral palsy at 18 to 22 months (trial entry before three days based on oxygenation) (RR 1.85, $95 \% \mathrm{Cl} 0.93$ to 3.71; two trials; 209 children); cerebral palsy at two years' corrected age or at 30 months (trial entry after three days based on bronchopulmonary dysplasia risk) (RR $1.10,95 \% \mathrm{Cl} 0.54$ to 2.23 ; two trials; 498 children); or cerebral palsy at one or two years' corrected age (trials of routine use in intubated preterm infants) (RR $0.94,95 \% \mathrm{Cl} 0.51$ to 1.70; two trials; 593 children) (Table 6). Low- to very low-quality evidence from Barrington 2010 also suggested no clear differences for neurodevelopmental disability at 18 to 22 months (trial entry before three days based on oxygenation) (RR 1.05, 95\% Cl 0.78 to 1.40; two trials; 208 children), neurodevelopmental disability at two years' corrected age or at 30 months (trial entry after three days based on bronchopulmonary dysplasia risk) (RR 0.90, 95\% Cl 0.74 to 1.09; two trials; 498 children), or neurodevelopmental disability at one or two years' corrected age (trials of routine use in intubated preterm infants) (RR $0.90,95 \% \mathrm{Cl} 0.72$ to 1.13 ; two trials; 593 children) following inhaled nitric oxide versus placebo or no treatment (Table 10). Moderate-quality evidence from Barrington 2010 also showed no clear differences for Bayley Mental or Psychomotor Developmental Index less than minus two standard deviations below the mean at two years' corrected age (trials of routine use in intubated preterm infants) following inhaled nitric oxide versus placebo ( $\mathrm{RR} 0.56,95 \% \mathrm{Cl} 0.33$ to 0.93 ; one trial; 138 children) (Table 11).

\section{Neonatal care: preventing/treating apnoea}

Low-quality evidence from the Henderson-Smart 2010b review suggested no clear differences for cerebral palsy at 18 to 21 months' corrected age following caffeine versus placebo for treatment of apnoea in preterm infants ( $\mathrm{RR} 0.60,95 \% \mathrm{Cl} 0.29$ to 1.25 ; one trial; 729 children) (Table 6). Low-quality evidence from HendersonSmart 2010b also suggested no clear differences in death or major disability at 18 to 21 months' corrected age following caffeine versus placebo (RR $0.85,95 \% \mathrm{Cl} 0.71$ to 1.01 ; one trial; 767 children) (Table 10).

Low-quality evidence from the Henderson-Smart 2010c review suggested no clear differences for cerebral palsy at 18 to 21 months' corrected age following caffeine versus placebo for prevention of apnoea in preterm infants (RR $1.03,95 \% \mathrm{Cl} 0.43$ to 2.49 ; one trial; 415 children) (Table 6). Low-quality evidence from HendersonSmart 2010c also suggested no clear differences in death or major disability at 18 to 21 months' corrected age following caffeine versus placebo (RR $1.00,95 \% \mathrm{Cl} 0.80$ to 1.24 ; one trial; 423 children) (Table 10).

\section{Neonatal care: preventing respiratory distress syndrome}

Low-quality evidence from the Soll 2010 review suggested no clear differences for cerebral palsy at one to two years following prophylactic protein-free synthetic surfactant versus placebo for preventing morbidity and mortality in preterm infants (RR 0.93, $95 \% \mathrm{Cl} 0.64$ to 1.33; four trials; 670 children) (Table 6). Subgroup analyses were conducted that were based on surfactant product (Exosurf Neonatal, DPPC/HDL; Burroughs Wellcome, Research Triangle Park, North Carolina, USA); however, formal tests for subgroup differences were not applied in the review (Table 7). Lowquality evidence from Soll 2010 also suggested no clear differences for moderate or severe cerebral palsy at one or two years following prophylactic protein-free synthetic surfactant versus placebo (RR $0.92,95 \% \mathrm{Cl} 0.53$ to 1.59 ; four trials; 670 children) (Table 9).

\section{Neonatal care: mechanical ventilation}

Low-quality evidence from the Wheeler 2010 review suggested no clear differences for severe disability at six to 18 months and at 22 months (RR 0.86, 95\% Cl 0.47 to 1.59; two trials; 209 children), for severe disability at 22 months or at death (RR $0.54,95 \% \mathrm{Cl}$ 0.27 to 1.06; one trial; 109 children) (Table 10), and for gross motor developmental issues (RR $1.00,95 \% \mathrm{Cl} 0.47$ to 2.14 ; one trial; 128 children) (Table 11) following volume-targeted versus pressurelimited ventilation in the neonate.

\section{Neonatal care: preventing/treating bronchopulmonary dysplasia}

Low-quality evidence from the Doyle 2014 review suggested no clear differences for cerebral palsy at one to three years (RR 1.06, $95 \% \mathrm{Cl} 0.76$ to $1.50 ; 14$ trials; 876 children), cerebral palsy at one to three years among survivors assessed (RR $1.05,95 \% \mathrm{Cl}$ 0.75 to $1.47 ; 14$ trials; 631 children), cerebral palsy at latest age reported (one year up to 17 years) (RR $1.12,95 \% \mathrm{Cl} 0.79$ to $1.60 ; 15$ trials; 855 children), or cerebral palsy at latest age reported among 
survivors assessed (one year up to 17 years) (RR 1.12, 95\% Cl 0.79 to $1.58 ; 15$ trials; 591 children) following late (more than seven days of age) postnatal corticosteroids versus placebo or no treatment for chronic lung disease in preterm infants (Table 6). Low-quality evidence from Doyle 2014 also suggested no clear differences for cerebral palsy or death at one to three years (RR 0.92, 95\% Cl 0.76 to $1.12 ; 14$ trials; 876 children), cerebral palsy or death at latest age reported (one year up to 17 years) (RR $0.95,95 \% \mathrm{Cl} 0.77$ to 1.16 ; 15 trials; 855 children) (Table 8), major neurosensory disability at one year corrected age up to 11 years (RR $1.17,95 \% \mathrm{Cl} 0.85$ to 1.60 ; eight trials; 655 children), major neurosensory disability among survivors assessed at one year corrected age up to 11 years (RR $1.10,95 \% \mathrm{Cl} 0.81$ to 1.50 ; eight trials; 480 children), death or major neurosensory disability at one year corrected age up to 11 years (RR 1.10, 95\% Cl 0.81 to 1.50; eight trials; 655 children) (Table 10), Bayley Scales of Infant Development Psychomotor Development Index less than minus two standard deviations below the mean at one year corrected age (RR $0.78,95 \% \mathrm{Cl} 0.34$ to 1.80 ; one trial; 118 children), or Bayley Scales of Infant Development Psychomotor Development Index less than minus two standard deviations below the mean among survivors assessed at one year corrected age (RR $0.67,95 \% \mathrm{Cl} 0.30$ to 1.50 ; one trial; 90 children) (Table 11) with late postnatal corticosteroids versus placebo or no treatment.

Low-quality evidence from the Darlow 2016 review suggested no clear differences for neurodevelopmental impairment at 18 to 24 months following supplemental vitamin A versus a sham injection to prevent mortality and short- and long-term morbidity in very low birthweight infants (RR $0.89,95 \% \mathrm{Cl} 0.74$ to 1.08 ; one trial; 538 children) (Table 10). Moderate-quality evidence also showed no clear differences for death or neurodevelopmental impairment at 18 to 24 months following supplemental vitamin A versus a sham injection (RR 0.92, 95\% Cl 0.81 to 1.05; one trial; 687 children) (Table 10).

\section{Neonatal care: preventing necrotising enterocolitis}

Low-quality evidence from the Shah 2007 review suggested no clear differences for cerebral palsy at 36 months' post-menstrual age following arginine supplementation versus placebo for prevention of necrotising enterocolitis in preterm infants (RR $0.88,95 \% \mathrm{Cl} 0.21$ to 3.80 ; one trial; 135 children) (Table 6). Low-quality evidence from Shah 2007 also suggested no clear differences for major neurodevelopmental disability at 36 months' post-menstrual age following arginine supplementation versus placebo (RR 0.65, 95\% Cl 0.23 to 1.83; one trial; 132 children) (Table 10).

\section{Neonatal care: preventing/treating fungal infection}

Low-quality evidence from the Cleminson 2015 review suggested no clear differences for cerebral palsy at 18 to 22 months post term following use of a systemic antifungal agent versus placebo to prevent mortality and morbidity in very low birthweight infants (RR 0.96, 95\% Cl 0.45 to 2.03; one trial; 219 children) (Table 6). Low-quality evidence from Cleminson 2015 also suggested no clear differences for neurodevelopmental impairment (composite) at 18 to 22 months following use of a systemic antifungal agent versus placebo (RR 1.13, 95\% Cl 0.71 to 1.81 ; one trial; 171 children) (Table 10).

\section{Neonatal care: parenteral feeding}

Moe-Byrne 2016 assessed glutamine supplementation versus placebo to prevent morbidity and mortality in preterm infants and reported the following: "van den Berg 2005 reported neurodevelopmental outcomes for infants aged two years post term. Outcomes assessed included...incidence of cerebral palsy... No significant differences between the glutamine and the control groups were reported for any of these individual outcomes" (not graded) (Table 6). Low-quality evidence from the Moe-Byrne 2016 review also suggested no clear differences for neurodevelopmental impairment at two years post term following glutamine supplementation versus placebo (RR $1.07,95 \% \mathrm{Cl} 0.59$ to 1.92; one trial; 72 children) (Table 10).

\section{Neonatal care: other}

Low-quality evidence from both the Osborn 2001 and Osborn 2007 reviews suggested no clear differences for cerebral palsy at 5.7 years following prophylactic thyroid hormones versus placebo for prevention of morbidity and mortality in preterm infants (RR $0.72,95 \% \mathrm{Cl} 0.28$ to 1.84 ; one trial; 156 children) (Table 6). In Osborn 2007, subgroup analyses based on dosing strategy, timing, and methodological quality were not possible for this outcome, with the one included trial using T4 $8 \mathrm{mcg} / \mathrm{kg} / \mathrm{d}$, on days 1 to 42, commencing within 48 hours, and being of adequate methodological quality (Table 7). Low-quality evidence from both Osborn 2001 and Osborn 2007 also suggested no clear differences for cerebral palsy or death at 5.7 years following prophylactic thyroid hormones versus placebo ( $\mathrm{RR} 0.70,95 \% \mathrm{Cl} 0.43$ to 1.14 ; one trial; 200 children) (Table 8).

Low-quality evidence from the Conde-Agudelo 2016 review suggested no clear differences for cerebral palsy at 12 months' corrected age following kangaroo mother care versus conventional neonatal care to reduce morbidity and mortality among low birthweight infants (RR $0.65,95 \% \mathrm{Cl} 0.21$ to 2.02; one trial; 588 children) (Table 6).

Low-quality evidence from the Spittle 2015 review suggested no clear differences for cerebral palsy at 18 months to six years following early developmental intervention versus standard follow-up post hospital discharge to prevent motor and cognitive impairment in preterm infants (RR $0.82,95 \% \mathrm{Cl} 0.52$ to 1.27 ; seven trials; 985 children) (Table 6). Subgroup analyses based on commencement of intervention (inpatient, post hospital discharge), focus of intervention (parent-infant relationship and infant development, infant development), and quality of studies (high-quality studies, lower-quality studies) were performed for this outcome; however, formal subgroup interaction tests were not applied in the review (Table 7). Low-quality evidence from Spittle 2015 also suggested no clear differences for motor outcome at school age (five years) following early developmental intervention versus standard follow-up (RR $1.12,95 \% \mathrm{Cl} 0.87$ to 1.44 ; two trials; 333 children) (Table 11).

\section{No conclusions possible: very low-quality evidence}

Neonatal care: preventing haemorrhage: periventricular/ intraventricular

Very low-quality evidence from the Smit 2013 review suggested no clear differences for severe neurodevelopmental impairment at 27 months (RR 1.44, 95\% Cl 0.41 to 5.04; one trial; 101 children) nor for mild neurodevelopmental impairment at 27 months (RR $0.57,95 \% \mathrm{Cl} 0.15$ to 2.17 ; one trial; 101 children) following phenobarbital versus no treatment for prevention of intraventricular haemorrhage in preterm infants (Table 10). 


\section{Neonatal care: treating hypotension}

Very low-quality evidence from the Osborn 2007b review suggested no clear differences for cerebral palsy at three years among survivors assessed following dobutamine versus dopamine in preterm infants with low superior vena cava flow (RR 0.16, 95\% $\mathrm{Cl} 0.01$ to 2.64; one trial; 13 children) (Table 6). Very low-quality evidence from Osborn 2007b also suggested no clear differences for disability at three years among survivors (RR $0.10,95 \% 0.01$ to 1.56 ; one trial; 13 children), for death or disability at three years (RR 0.79, 0.57 to 1.11 ; one trial; 37 children), or for death or disability at latest follow-up (one to three years) (RR $0.95,95 \% \mathrm{Cl} 0.66$ to 1.38 ; one trial; 41 children) following dobutamine versus dopamine (Table 10).

\section{Neonatal care: treating patent ductus arteriosus}

Very low-quality evidence from Ohlsson 2015 suggested no clear differences for moderate or severe cerebral palsy at 18 to 24 months following oral ibuprofen versus intravenous ibuprofen for treatment of patent ductus arteriosus in preterm or low birthweight (or both) infants (RR 1.35, 95\% $\mathrm{Cl} 0.24$ to 7.48 ; one trial; 57 children) (Table 6).

\section{Neonatal care: preventing blood disorders}

Very low-quality evidence from Ohlsson 2014 suggested no clear differences for cerebral palsy at 18 to 22 months' corrected age among children examined following erythropoietin versus placebo for preventing red blood cell transfusion in preterm and/or low birthweight infants (RR $0.66,95 \% \mathrm{Cl} 0.31$ to 1.37 ; two trials; 153 children) (Table 6). Very low-quality evidence from Ohlsson 2014 also suggested no clear differences for any neurodevelopmental impairment at 18 to 22 months' corrected age among children examined (RR $0.97,95 \% \mathrm{Cl} 0.62$ to 1.51; one trial; 99 children) (Table 10) nor for Psychomotor Developmental Index less than 70 at 18 to 22 months' corrected age among children examined (RR 2.33, $95 \% \mathrm{Cl} 0.98$ to 5.53 ; one trial; 90 children) following erythropoietin versus placebo (Table 11).

\section{Neonatal care: preventing/treating respiratory distress syndrome}

Very low-quality evidence from Howlett 2015 suggested no clear differences for major neural developmental impairment at one year corrected age (RR $0.53,95 \% \mathrm{Cl} 0.24$ to 1.16 ; one trial; 169 children) (Table 10) nor for minor neural developmental impairment at one year corrected age (RR $0.84,95 \% \mathrm{Cl} 0.38$ to 1.86; one trial; 169 children) following inositol supplementation (repeat doses) versus placebo in preterm infants at risk for or having respiratory distress syndrome (Table 11).

Very low-quality evidence from Seger 2009 suggested no clear differences for cerebral palsy at one and two years' corrected age following animal-derived surfactant extract versus no treatment for respiratory distress syndrome ( $\mathrm{RR} 0.88,95 \% \mathrm{Cl} 0.34$ to 2.27 ; one trial; 73 children) (Table 6). Subgroup analysis based on surfactant product for this outcome was not applicable, with the one included trial using porcine surfactant extract (Table 7). Very low-quality evidence from Seger 2009 also suggested no clear differences for major developmental disability among survivors at one and two years' corrected age following animal-derived surfactant extract versus no treatment (RR 3.30, 95\% 0.14 to 26.78; one trial; 73 children) (Table 10).

\section{Neonatal care: mechanical ventilation}

Very low-quality evidence from the Ho 2015 review suggested no clear differences for cerebral palsy at nine to 15 years following continuous distending pressure versus standard care for respiratory distress in preterm infants (RR 5.0, 95\% Cl 0.26 to 97.37 ; one trial; 36 children) (Table 6). Subgroup analysis based on type of continuous distending pressure was not possible for this outcome, with the only included trial using continuous negative pressure (Table 7). Very low-quality evidence from Ho 2015 also suggested no clear differences for death or severe disability at nine to 15 years (RR $1.33,95 \% \mathrm{Cl} 0.34,5.17$; one trial; 38 children), for severe disability at nine to 15 years (RR $1.06,95 \% \mathrm{Cl} 0.24$ to 4.57 ; one trial; 37 children), or for any disability at nine to 15 years (RR $0.62,95 \% \mathrm{Cl} 0.31$ to 1.21 ; one trial; 37 children) following continuous distending pressure versus standard care (Table 10).

Very low-quality evidence from the Kamlin 2003 review suggested no clear differences for cerebral palsy among survivors at less than 33 weeks' gestation, at birth, and at 18 months following long versus short inspiratory times among neonates receiving mechanical ventilation (RR 2.9, 95\% $\mathrm{Cl} 0.97$ to 8.65; one trial; 177 children) (Table 6).

\section{Neonatal care: preventing bronchopulmonary dysplasia}

Very low-quality evidence from the Halliday 2003 review suggested no clear differences for cerebral palsy at 12 months' corrected age up to 90 months (RR $1.03,95 \% \mathrm{Cl} 0.47$ to 2.24; four trials; 204 children) nor for cerebral palsy among survivors assessed at 12 months' corrected age up to 90 months (RR $0.83,95 \% \mathrm{Cl} 0.39$ to 1.74; four trials; 130 children) following moderately early (between seven and 14 days of age) postnatal corticosteroids versus placebo or no treatment for preventing chronic lung disease in preterm infants (Table 6). Very low-quality evidence from Halliday 2003 also suggested no clear differences for cerebral palsy or death at 12 months' corrected age up to 90 months (RR $0.83,95 \% \mathrm{Cl} 0.55$ to 1.23; four trials; 204 children) (Table 8), for major neurosensory disability at 15 months' corrected age up to 90 months (RR 1.26, 95\% Cl 0.45 to 3.49; two trials; 96 children), for major neurosensory disability among survivors assessed at 15 months' corrected age up to 90 months (RR $0.89,95 \% \mathrm{Cl} 0.38$ to 2.10 ; two trials; 56 children), or for death or major neurosensory disability at 15 months' corrected age up to 90 months (RR 1.02, 95\% Cl 0.66 to 1.56; two trials; 96 children) with moderately early postnatal corticosteroids versus placebo or no treatment (Table 10).

Very low-quality evidence from the Shah 2012 review suggested no clear differences in cerebral palsy at three years with early inhaled corticosteroids versus placebo for preventing chronic lung disease among ventilated very low birthweight preterm neonates (RR 1.33, $95 \% \mathrm{Cl} 0.33$ to 5.42 ; one trial; 56 children) (Table 6). Very low-quality evidence from Shah 2012 also suggested no clear differences for mean developmental index less than two standard deviations of the mean on the Bayley Scales of Infant Development with early inhaled corticosteroids versus placebo (RR $1.25,95 \% \mathrm{Cl} 0.37$ to 4.17 ; one trial; 56 children) (Table 11).

\section{Neonatal care: preventing necrotising enterocolitis}

Very low-quality evidence from the AlFaleh 2014 review suggested no clear differences for mental retardation and cerebral palsy at six years following probiotics versus control (distilled water) for 
prevention of necrotising enterocolitis in preterm infants (RR 1.02, $95 \% \mathrm{Cl} 0.15$ to 6.94 ; one trial; 85 children) (Table 10 ).

\section{Neonatal care: other}

Very low-quality evidence from the Almadhoob 2015 review suggested no clear differences for cerebral palsy at 18 to 22 months' corrected age with use of silicone earplugs versus no earplugs in the neonatal intensive care unit for preterm or very low birthweight infants (RR 3.0, 95\% Cl 0.14 to 63.15; one trial; 14 children) (Table 6).

\section{No conclusions possible: not graded}

\section{Neonatal care: mechanical ventilation}

The Cools 2015 review assessed elective high-frequency oscillatory ventilation versus conventional ventilation for acute pulmonary dysfunction in preterm infants. Cools 2015 did not perform a metaanalysis for the outcome cerebral palsy, with age and methods of assessment varying between studies, and rather reported the results for three separate trials in text, as below (not graded) (Table $6)$.

1. "Neurodevelopmental status was assessed at 16 to 24 months' corrected age in $77 \%$ of survivors of the HIFI 1989 study (185 HFOV and 201 CV) using Bayley psychometric tests and central nervous system examinations... The rate of cerebral palsy was $11 \%$ in both groups".

2. "Moriette 2001 assessed neuromotor outcome at the corrected age of two years in 192 of 212 survivors (90\%) using a physician questionnaire...the risk of spastic cerebral palsy was significantly lower for infants ventilated with HFOV (4\% versus $17 \%$; OR $0.87,95 \% \mathrm{Cl} 0.79$ to 0.96 ), even after adjustment for multiple factors. Survival without cerebral palsy was significantly more likely in the HFOV group than in the CV group (OR $1.89,95 \% \mathrm{Cl} 1.04$ to 3.44 )".

3. "Sun 2014 assessed neurodevelopmental outcomes at 18 months' corrected age in 145 infants of the HFOV group (84\% of survivors) and in 143 infants of the CV group ( $86 \%$ of survivors). Cerebral palsy occurred significantly less in the HFOV group $(3 \%$ versus $10 \%$ in the $C V$ group, $P=0.03) "$.

\section{Interventions for other specific groups of 'at risk' neonates}

\section{No conclusions possible: low-quality evidence}

\section{Neonatal care: treating pulmonary hypertension}

Low-quality evidence from the More 2016 review suggested no clear differences for cerebral palsy at six months following use of endothelin receptor antagonists versus placebo for persistent pulmonary hypertension in term and late preterm infants (RR 0.09 , $95 \% \mathrm{Cl} 0.00$ to 1.61; one trial; 37 children) (Table 6). Low-quality evidence from More 2016 also suggested no clear differences for adverse neurological outcomes at six months with use of endothelin receptor antagonists versus placebo (RR $0.07,95 \% \mathrm{Cl}$ 0.00,1.20; one trial; 37 children) (Table 11).

\section{Neonatal care: nitric oxide}

Low-quality evidence from the Finer 2006 review suggested no clear differences for cerebral palsy among survivors at 13 or 18 to 24 months following inhaled nitric oxide versus placebo for respiratory failure in infants born at or near term (RR 1.02, 95\% $\mathrm{Cl} 0.49$ to 2.14; two trials; 299 children) (Table 6). Finer 2006 also reported on an additional trial not included in the meta-analysis for this outcome: "This group [Wessel 1996] has now published follow up data, including neurodevelopmental outcomes, which were obtained by telephone interview of 60 of the 83 survivors of the original trial. The interview was conducted between one and four years of age... Although cerebral palsy [was] reported it is unclear how [it] was defined... It is not, therefore, possible to add any of these data to the meta-analysis, but they do appear to show no evidence of neurodevelopmental impairment due to inhaled nitric oxide therapy" (not graded). Low-quality evidence from Finer 2006 also suggested no clear differences for neurodevelopmental disability among survivors at 13 or 18 to 24 months (RR 0.97 , $95 \% \mathrm{Cl} 0.66$ to 1.44; two trials; 301 children) (Table 10) nor for Bayley Psychomotor Developmental Index more than two standard deviations below the mean at 13 or 18 to 24 months (RR $1.09,95 \%$ $\mathrm{Cl} 0.58$ to 2.03; two trials; 283 children) (Table 11) following inhaled nitric oxide versus placebo.

\section{No conclusions possible: very low-quality evidence}

\section{Neonatal care: resuscitation}

Very low-quality evidence from the Tan 2005 review suggested no clear differences for cerebral palsy among those followed up at 18 to 24 months following room air versus $100 \%$ oxygen for resuscitation of infants at birth (RR $1.34,95 \% \mathrm{Cl} 0.55$ to 3.24 ; one trial; 213 children) (Table 6). Very low-quality evidence from Tan 2005 also suggested no clear differences in not walking among those followed up at 18 to 24 months following room air versus $100 \%$ oxygen (RR 1.03, 95\% Cl 0.04 to 2.25; one trial; 213 children) (Table 11).

\section{Neonatal care: nitric oxide}

Very low-quality evidence from the Finer 2006 review suggested no clear differences for cerebral palsy among survivors at 18 to 24 months following inhaled nitric oxide versus placebo for respiratory failure among infants with diaphragmatic hernias born at or near term (RR 8.33, 95\% Cl 0.45 to 154.78; one trial; 22 children) (Table 6).

\section{Neonatal care: treating herpes simplex}

Very low-quality evidence from the Jones 2009 review suggested no clear differences in cerebral palsy in central nervous system herpes simplex virus (HSV) neonatal infection up to three years by HSV serotype: HSV-1 (no events, one trial, nine children) and HSV-2 (RR 1.07, $95 \% \mathrm{Cl} 0.49$ to 2.33; one trial; 14 children) following acyclovir versus vidarabine for treatment of HSV infection in neonates (Table 6). Very low-quality evidence from Jones 2009 also suggested no clear differences for abnormal neurodevelopment at approximately one year of age (RR 1.50, 95\% 0.62 to 3.65; one trial; 56 children) nor for abnormal neurodevelopment or death at approximately one year of age (RR $0.86,95 \% \mathrm{Cl} 0.60$ to 1.22 ; one trial; 56 children) following vidarabine versus placebo; and abnormal neurodevelopment at approximately one year of age (RR 0.82, 95\% 0.50 to 1.34; one trial; 202 children) or abnormal neurodevelopment or death at approximately one year of age (RR $0.79,95 \% \mathrm{Cl} 0.57$ to 1.10 ; one trial; 202 children) following acyclovir versus vidarabine (Table 10 ).

\section{Neonatal care: treating hypoglycaemia}

Very low-quality evidence from the Weston 2016 review suggested no clear differences in cerebral palsy at age two years following dextrose gel versus placebo for treatment of hypoglycaemia in newborn infants (RR 5.16, $95 \% \mathrm{Cl} 0.25$ to 106.12; one trial; 
183 children) (Table 6). Very low-quality evidence from Weston 2016 also suggested no clear differences in major neurosensory disability at two years (RR 6.27, 95\% Cl 0.77 to 51.03; one trial; 184 children) nor in any developmental disability at two years (RR 1.11, $95 \% \mathrm{Cl} 0.75$ to 1.63 ; one trial; 184 children) following dextrose gel versus placebo (Table 10).

\section{DISCUSSION}

\section{Summary of main results}

This review included 43 Cochrane Reviews with outcome data for cerebral palsy available from meta-analyses of data from 96 randomised controlled trials (RCTs) involving 15,885 children.

\section{Interventions for neonates with perinatal asphyxia or with} evidence of neonatal encephalopathy

1. Effective interventions (high-quality evidence of effectiveness): High-quality evidence showed a reduction in cerebral palsy following therapeutic hypothermia versus standard care for newborns with hypoxic ischaemic encephalopathy.

2. No conclusions possible: very low-quality evidence: Very lowquality evidence suggested no clear differences in cerebral palsy following barbiturates (phenobarbital) versus conventional therapy for prevention of morbidity and mortality following perinatal asphyxia.

Interventions for neonates born preterm and/or at low or very low birthweight

1. Possibly effective interventions (moderate-quality evidence of effectiveness): Moderate-quality evidence showed a reduction in cerebral palsy with prophylactic methylxanthines (caffeine) versus placebo for endotracheal extubation in preterm infants.

2. Probably ineffective interventions (moderate-quality evidence of harm): Moderate-quality evidence showed an increase in cerebral palsy and cerebral palsy among survivors assessed following early (less than eight days) postnatal corticosteroids versus control for preventing chronic lung disease in preterm infants.

3. Probably ineffective interventions (moderate-quality evidence of lack of effectiveness): Moderate-quality evidence showed no clear differences in cerebral palsy following ethamsylate versus placebo for prevention of morbidity and mortality in preterm or very low birthweight infants; volume versus no treatment and gelatin versus fresh frozen plasma for prevention of morbidity and mortality in very preterm infants; prophylactic indomethacin versus placebo or no drug for preventing mortality and morbidity in preterm infants; synthetic surfactant versus placebo for respiratory distress syndrome in preterm infants; or prophylactic phototherapy versus standard care (starting phototherapy when serum bilirubin reached a pre-specified level) for preventing jaundice in preterm or low birthweight infants.

4. No conclusions possible (low- to very low-quality evidence): Low- to very low-quality evidence suggested no clear differences for cerebral palsy following dobutamine versus dopamine in preterm infants with low superior vena cava flow; oral ibuprofen versus intravenous ibuprofen for treatment of patent ductus arteriosus in preterm or low birthweight (or both) infants; darbepoetin alfa versus placebo and erythropoietin versus placebo for preventing red blood cell transfusion in preterm and/or low birthweight infants; transfusion at a restrictive (low haemoglobin) versus a liberal (high haemoglobin) threshold for preventing morbidity and mortality in very low birthweight infants; inhaled nitric oxide versus placebo or no treatment for respiratory failure in preterm infants; caffeine versus placebo for treatment of apnoea in preterm infants; caffeine versus placebo for prevention of apnoea in preterm infants; animalderived surfactant extract versus no treatment for treatment of respiratory distress syndrome; prophylactic protein-free synthetic surfactant versus placebo for preventing morbidity and mortality in preterm infants; continuous distending pressure versus standard care for respiratory distress in preterm infants; long versus short inspiratory times in neonates receiving mechanical ventilation; moderately early (between seven and 14 days of age) postnatal corticosteroids versus placebo or no treatment for preventing chronic lung disease in preterm infants; late (more than seven days of age) postnatal corticosteroids versus placebo or no treatment for chronic lung disease in preterm infants; early inhaled corticosteroids versus placebo for preventing chronic lung disease in ventilated very low birthweight preterm neonates; arginine supplementation versus placebo for prevention of necrotising enterocolitis in preterm infants; systemic antifungal agents versus placebo for prevention of mortality and morbidity in very low birthweight infants; prophylactic thyroid hormones versus placebo for prevention of morbidity and mortality in preterm infants; use of silicone earplugs versus no earplugs in the neonatal intensive care unit for preterm or very low birthweight infants; kangaroo mother care versus conventional neonatal care to reduce morbidity and mortality in low birthweight infants; and early developmental intervention versus standard follow-up post hospital discharge to prevent motor and cognitive impairment in preterm infants.

\section{Interventions for other specific groups of 'at risk' neonates}

1. No conclusions possible (low- to very low-quality evidence): Low- to very low-quality evidence suggested no clear differences for cerebral palsy following endothelin receptor antagonists versus placebo for persistent pulmonary hypertension in term and late preterm infants; inhaled nitric oxide versus placebo for respiratory failure in infants born at or near term; room air versus $100 \%$ oxygen for resuscitation of infants at birth; acyclovir versus vidarabine for treatment of HSV infection in neonates; and dextrose gel versus placebo for treatment of hypoglycaemia in newborn infants.

\section{Overall completeness and applicability of evidence}

This overview summarises published Cochrane Systematic Reviews assessing neonatal interventions reporting on cerebral palsy and does not consider interventions in the antenatal or intrapartum period, which is the focus of a companion overview (Shepherd 2016).

We were able to include only 43 reviews (representing less than $13 \%$ of the 343 Neonatal reviews in the Cochrane Database of Systematic Reviews). We identified an additional 40 protocols that have prespecified cerebral palsy as a primary or secondary outcome and will be considered for inclusion in future updates of the overview 
when they have been published as full reviews. These protocols plan to assess a variety of interventions (see Appendix 1: 'Ongoing reviews'). We were not able to include an additional 102 reviews assessing a wide range of neonatal interventions, although we recognised the potential impact of the intervention of interest on cerebral palsy (through pre-specifying cerebral palsy as a review outcome); none of the included trials within these reviews reported on this outcome. We summarised the main conclusions of these reviews in Appendix 2 ('Reviews awaiting further classification') and will again consider them for inclusion in future updates of the overview. In total, the 43 reviews included 454 RCTs involving infants.

Although the 43 reviews in this overview included 454 randomised trials involving over 63,977 infants, the body of evidence for our review was substantially reduced by the fact that the included reviews (and trials) did not report on our overview outcomes. For our primary outcome - cerebral palsy - we included data from metaanalyses of 35 reviews involving 96 randomised trials, or only $21 \%$ of the trials within the included reviews.

The body of evidence for our secondary outcomes was further reduced for the composite outcome including cerebral palsy (30 reviews), motor dysfunction (12 reviews), cerebral palsy or death (five reviews), and severity of cerebral palsy (three reviews). None of our included reviews reported specifically on type of cerebral palsy. For most of our outcomes, reviews reported data from only one or two trials, up to a maximum of 15 trials. Thus, review authors often presented too few data to permit firm conclusions on effects on cerebral palsy and on our secondary outcomes. For most of the included reviews, data related to cerebral palsy were commonly short term (reported at one to three years of age), and longerterm follow-up was less commonly reported (although follow-up to 17 years was reported). Included reviews often did not report information regarding definitions nor criteria for cerebral palsy diagnosis and assessment methods.

We did not attempt to make indirect comparisons to address questions concerning the relative performance of different neonatal interventions. Rather we aimed to systematically consider all potentially relevant interventions for their ability to contribute to prevention of cerebral palsy. Within this overview, we did not attempt to duplicate details of participants and interventions (and control conditions) in individual trials. The reader may refer to these individual reviews and trials for more information on these factors. Further, the scope of this overview was limited to effects of interventions on cerebral palsy (and a restricted number of prespecified secondary review outcomes). To assess effects (benefits or harms) of the included interventions on other outcomes, readers are encouraged to refer to the included Cochrane Reviews themselves. For example, although low-quality evidence presented in this overview suggested no clear differences in cerebral palsy following kangaroo mother care, the Conde-Agudelo 2016 review reported moderate-quality evidence of benefit for outcomes including mortality, severe infection/sepsis, hypothermia, weight gain, and breastfeeding, and thus supports the use of kangaroo mother care for low birthweight infants as an alternative to conventional neonatal care (mainly in resource-limited settings). Similarly, although very low-quality evidence in this overview suggested no clear differences in cerebral palsy following dextrose gel for treatment of hypoglycaemia, the Weston 2016 review found moderate-quality evidence of benefit for outcomes including mother-infant separation and breastfeeding, and thus concluded that oral dextrose therapy should be considered first-line treatment for neonates with hypoglycaemia.

Although our overview could demonstrate high-quality evidence of a reduction in cerebral palsy following therapeutic hypothermia for newborns with hypoxic-ischaemic encephalopathy (Jacobs 2013), the incidence of death and disability, including cerebral palsy, remains high despite therapy. Thus, optimisation of hypothermia strategies or adjuvant therapies is urgently needed to further improve outcomes. A range of possible agents such as antiepileptic drugs (including topiramate), xenon, erythropoietin, melatonin, magnesium sulphate, and cord blood continue to be under investigation (AAP 2014; Robertson 2012).

\section{Quality of the evidence}

We assessed almost all of the included reviews to be of high quality and to have low risk of bias using the AMSTAR and ROBIS tools (see Table 4: AMSTAR assessments for included reviews; and Table 5: ROBIS assessments for included reviews). Although these two tools differ in their approaches to assessing review quality or risk of bias, findings of these assessments were similar. All of the included reviews assessed risk of bias of included randomised trials (most used current guidance as outlined in Chapter 8 of the Cochrane Handbook for Systematic Reviews of Interventions (Higgins 2011)), and the quality of randomised trials was variable within and between reviews (see Table 3: Risk of bias assessments from included reviews). Six of the 43 reviews used the GRADE approach to assess the quality of evidence for overview outcomes (Darlow 2016; Moe-Byrne 2016; More 2016; Okwundu 2012; Weston 2016; Young 2016). For the other reviews, we used the GRADE system to rate the quality of evidence and incorporated assessments of study limitations (risk of bias) as reported by the review authors. For our primary review outcome - cerebral palsy - evidence ranged from very low to high quality, and for our secondary review outcomes, quality of evidence varied similarly. Downgrading of quality was most commonly due to study limitations (risk of bias) and imprecision (small sample sizes, low numbers of events, and wide confidence intervals). Findings regarding the quality of evidence for each outcome are set out in Table 6: Cerebral palsy; Table 8: Cerebral palsy or death; Table 9: Severity of cerebral palsy; Table 10: Other composite outcomes that include cerebral palsy as a component; and Table 11: Motor dysfunction.

\section{Potential biases in the overview process}

We were aware of risks of introducing bias at all stages of the overview process, and we took several steps to minimise this, including developing a Cochrane overview protocol. At least two overview authors independently assessed reviews for inclusion, carried out data extraction and quality assessment, and assessed the quality of evidence using the GRADE approach. A potential source of bias is related to the fact that one overview author (Nadia Badawi) is an author of one of the included reviews (Jones 2009). As pre-specified in our protocol, two other overview authors, who were not authors of this review, carried out data extraction and quality assessment for this review.

We undertook a comprehensive search of the Cochrane Database of Systematic Reviews without applying language or date restrictions, and we identified published reviews, as well as planned/ongoing reviews (protocols). We did not search other databases; thus 
it is possible that non-Cochrane systematic reviews assessing neonatal interventions and reporting on cerebral palsy have been conducted but were not identified. It is also the case that Cochrane Reviews assessing interventions that could have the potential to impact cerebral palsy risk (see Description of the interventions for further discussion of various interventions) may not have acknowledged this through inclusion of cerebral palsy as a review outcome. Thus, data from relevant randomised trials assessing these interventions will not have been identified and included in this overview. Based on our search strategy, even Cochrane Reviews that pre-specified outcomes such as 'long-term growth and neurodevelopment' (Cools 2015) but subsequently reported specifically on 'cerebral palsy' were captured in our search and were included in this overview. However, reviews that have reported on long-term neurodevelopmental outcomes without any mention of 'cerebral palsy' will not have been identified; this highlights the need for all Cochrane Reviews to provide clear definitions accompanying any reported outcome measures.

Although we judged almost all of our included reviews to be of high quality and to have low risk of bias, we did not consider all as 'upto-date', with only approximately one-third conducting searches in the past three years; similarly, not all of the 'Reviews awaiting further classification' were 'up-to-date'. Thus, it is possible that additional trials assessing neonatal interventions and reporting on cerebral palsy have been published but have not yet been included in relevant Cochrane Reviews; it is also possible that additional trials have been conducted but have not yet been published. If/ when such trials are included in relevant Cochrane Reviews, we will incorporate them into an update of this overview.

\section{Agreements and disagreements with other studies or reviews}

We have not identified any other overviews or systematic reviews specifically designed to assess neonatal interventions for preventing cerebral palsy.

McIntyre 2013 conducted a systematic review of cohort and casecontrol studies that focused on identifying risk factors for cerebral palsy in children born at term and aimed to assess whether the potential for prevention of these risk factors has been adequately explored. Intrapartum and neonatal risk factors identified included birth asphyxia, neonatal seizures, respiratory distress syndrome, hypoglycaemia, jaundice, and infections including meningitis and sepsis. It is recognised that a strategy for prevention of cerebral palsy currently exists for only one of these risk factors - hypothermia for birth asphyxia - as was identified in this overview. Mclntyre 2013 highlighted that prevention strategies are urgently required.

A further recent systematic review - Hadders-Algra 2016 focused on early interventions in infants younger than 12 months' corrected age with or at very high risk for cerebral palsy (such as on the basis of a lesion of the brain periventricular leucomalacia or intraventricular haemorrhage, or definitely abnormal general movements). This review included seven studies of moderate to high quality assessing interventions such as neurodevelopmental treatment only, multisensory stimulation, developmental stimulation, and multi-faceted interventions combining developmental stimulation, support of parent-infant interaction, and neurodevelopmental treatment (Hadders-Algra 2016). Hadders-Algra 2016 concluded that although two suggestions emerged (dosing may be critical for effectiveness; multi-faceted interventions may offer the best opportunities), current evidence is limited.

\section{AUTHORS' CONCLUSIONS}

\section{Implications for practice}

This overview summarises the evidence from Cochrane Systematic Reviews of randomised controlled trials regarding effects of neonatal interventions on cerebral palsy, and can be used by researchers, funding bodies, policy makers, clinicians, and consumers to aid decision-making and evidence translation.

High-quality evidence shows that therapeutic hypothermia versus standard care for newborns with hypoxic-ischaemic encephalopathy can reduce cerebral palsy. Moderate-quality evidence shows that prophylactic methylxanthines (caffeine) versus placebo for endotracheal extubation in preterm infants may also reduce cerebral palsy risk. Moderate-quality evidence shows that early (less than eight days of age) postnatal corticosteroids versus placebo or no treatment for preventing chronic lung disease in preterm infants may increase cerebral palsy risk. In addition, moderate-quality evidence shows no clear differences in cerebral palsy risk with ethamsylate versus placebo for prevention of morbidity and mortality in preterm or very low birthweight infants; volume versus no treatment and gelatin versus fresh frozen plasma for prevention of morbidity and mortality in very preterm infants; prophylactic indomethacin versus placebo for prevention of mortality and morbidity in preterm infants; synthetic surfactant versus placebo for respiratory distress syndrome in preterm infants; or prophylactic phototherapy versus standard care (starting phototherapy when serum bilirubin reached a pre-specified level) for preventing jaundice in preterm or low birthweight infants. No conclusions were possible for other interventions assessed in this overview because evidence was of low to very low quality.

The scope of this overview was limited to the effects of interventions on cerebral palsy (and pre-specified secondary overview outcomes); consultation of the included Cochrane Reviews is recommended to formally assess additional benefits and/or harms of these interventions.

\section{Implications for research}

This overview highlights areas for which evidence is insufficient to permit conclusions on the effects of several neonatal interventions on cerebral palsy. These topics can be used to generate research questions and priorities. As cerebral palsy is rarely identified at birth, has diverse risk factors and aetiologies, and is diagnosed in approximately one in 500 children, it is a challenging outcome for investigators of such interventions to measure and report on. To date, a small proportion of Cochrane Reviews assessing neonatal interventions have reported on cerebral palsy; this may be due to a number of factors, including lack of primary research (with few randomised trials of neonatal interventions conducting longterm follow-up of children), lack of reporting on cerebral palsy by randomised trials, lack of reporting on cerebral palsy by relevant Cochrane Reviews (i.e. not pre-specifying it as an outcome of interest, not clearly defining long-term follow-up results reported, or not being 'up-to-date'), and the absence of Cochrane Reviews assessing relevant interventions.

With greater understanding of the diverse risk factors and aetiologies of cerebral palsy, there is an urgent need for long- 
term follow-up of interventions to address risk factors for cerebral palsy. In light of the challenges associated with long-term followup of randomised trials, new strategies to measure impact on cerebral palsy, such as data linkage with cerebral palsy registries, should be applied. Additionally, there is a need to consider the use of relatively new interim assessments (such as the General Movements Assessment). Such studies must be rigorous in their design and should aim for consistency in cerebral palsy outcome measurement and reporting to facilitate pooling of outcome data and thus aid research efforts aimed at prevention of cerebral palsy.

\section{ACKNOWLEDGEMENTS}

We thank the Cochrane Neonatal Editorial Base for its support. As part of the pre-publication editorial process, this review has been commented on by four editors, and the protocol for this review was commented on by four editors.

We thank the Cerebral Palsy Alliance Research Foundation Australia for funding this project. 


\section{R E F E R E N C E S}

\section{References to included reviews}

\section{AlFaleh 2014}

AlFaleh K, Anabrees J. Probiotics for prevention of necrotizing enterocolitis in preterm infants. Cochrane Database of Systematic Reviews 2014, Issue 4. [DOI: 10.1002/14651858.CD005496.pub4; PUBMED: 24723255]

\section{Almadhoob 2015}

Almadhoob A, Ohlsson A. Sound reduction management in the neonatal intensive care unit for preterm or very low birth weight infants. Cochrane Database of Systematic Reviews 2015, Issue 1. [DOI: 10.1002/14651858.CD010333.pub2; PUBMED: 25633155]

\section{Barrington 2010}

Barrington KJ, Finer N. Inhaled nitric oxide for respiratory failure in preterm infants. Cochrane Database of Systematic Reviews 2010, Issue 12. [DOI: 10.1002/14651858.CD000509.pub4; PUBMED: 21154346 ]

\section{Chaudhari 2012}

Chaudhari T, McGuire W. Allopurinol for preventing mortality and morbidity in newborn infants with hypoxic-ischaemic encephalopathy. Cochrane Database of Systematic Reviews 2012, Issue 7. [DOI: 10.1002/14651858.CD006817.pub3; PUBMED: 22786499]

\section{Cleminson 2015}

Cleminson J, Austin N, McGuire W. Prophylactic systemic antifungal agents to prevent mortality and morbidity in very low birth weight infants. Cochrane Database of Systematic Reviews 2015, Issue 10. [DOI: 10.1002/14651858.CD003850.pub5; PUBMED: 26497056 ]

\section{Conde-Agudelo 2016}

Conde-Agudelo A, Díaz-Rossello JL. Kangaroo mother care to reduce morbidity and mortality in low birthweight infants. Cochrane Database of Systematic Reviews 2016, Issue 8. [DOI: 10.1002/14651858.CD002771.pub4; PUBMED: 27552521]

\section{Cools 2015}

Cools F, Offringa M, Askie LM. Elective high frequency oscillatory ventilation versus conventional ventilation for acute pulmonary dysfunction in preterm infants. Cochrane Database of Systematic Reviews 2015, Issue 3. [DOI: 10.1002/14651858.CD000104.pub4; PUBMED: 25785789]

\section{Darlow 2016}

Darlow BA, Graham PJ, Rojas-Reyes MX. Vitamin A supplementation to prevent mortality and short- and long-term morbidity in very low birth weight infants. Cochrane Database of Systematic Reviews 2016, Issue 8. [DOI: 10.1002/14651858.CD000501.pub4; PUBMED: 27552058]

\section{Doyle 2014}

Doyle LW, Ehrenkranz RA, Halliday HL. Late ( 7 days) postnatal corticosteroids for chronic lung disease in preterm infants. Cochrane Database of Systematic Reviews 2014, Issue 5. [DOI: 10.1002/14651858.CD001145.pub3; PUBMED: 24825542]

\section{Doyle 2014b}

Doyle LW, Ehrenkranz RA, Halliday HL. Early ( $<8$ days) postnatal corticosteroids for preventing chronic lung disease in preterm infants. Cochrane Database of Systematic Reviews 2014, Issue 5. [DOI: 10.1002/14651858.CD001146.pub4; PUBMED: 24825456]

\section{Finer 2006}

Finer N, Barrington KJ. Nitric oxide for respiratory failure in infants born at or near term. Cochrane Database of Systematic Reviews 2006, Issue 4. [DOI: 10.1002/14651858.CD000399.pub2; PUBMED: 17054129]

\section{Fowlie 2010}

Fowlie PW, Davis PG, McGuire W. Prophylactic intravenous indomethacin for preventing mortality and morbidity in preterm infants. Cochrane Database of Systematic Reviews 2010, Issue 7. [DOI: 10.1002/14651858.CD000174.pub2; PUBMED: 20614421]

\section{Halliday 2003}

Halliday HL, Ehrenkranz RA, Doyle LW. Moderately early (7-14 days) postnatal corticosteroids for preventing chronic lung disease in preterm infants. Cochrane Database of Systematic Reviews 2003, Issue 1. [DOI: 10.1002/14651858.CD001144; PUBMED: 12535400$]$

\section{Henderson-Smart 2010}

Henderson-Smart DJ, Davis PG. Prophylactic methylxanthines for endotracheal extubation in preterm infants. Cochrane Database of Systematic Reviews 2010, Issue 12. [DOI: 10.1002/14651858.CD000139.pub2; PUBMED: 21154342]

\section{Henderson-Smart 2010b}

Henderson-Smart DJ, De Paoli AG. Methylxanthine treatment for apnoea in preterm infants. Cochrane Database of Systematic Reviews 2010, Issue 12. [DOI: 10.1002/14651858.CD000140.pub2; PUBMED: 21154343]

\section{Henderson-Smart 2010c}

Henderson-Smart DJ, De Paoli AG. Prophylactic methylxanthine for prevention of apnoea in preterm infants. Cochrane Database of Systematic Reviews 2010, Issue 12. [DOI: 10.1002/14651858.CD000432.pub2; PUBMED: 21154344]

\section{Ho 2015}

Ho JJ, Subramaniam P, Davis PG. Continuous distending pressure for respiratory distress in preterm infants. Cochrane Database of Systematic Reviews 2015, Issue 7. [DOI: 10.1002/14651858.CD002271.pub2; PUBMED: 26141572]

\section{Howlett 2015}

Howlett A, Ohlsson A, Plakkal N. Inositol in preterm infants at risk for or having respiratory distress syndrome. Cochrane Database of Systematic Reviews 2015, Issue 2. [DOI: 10.1002/14651858.CD000366.pub3; PUBMED: 25927089]

\section{Hunt 2010}

Hunt R, Hey E. Ethamsylate for the prevention of morbidity and mortality in preterm or very low birth weight infants. 
Cochrane Database of Systematic Reviews 2010, Issue 1. [DOI: 10.1002/14651858.CD004343.pub2; PUBMED: 20091562]

\section{Jacobs 2013}

Jacobs SE, Berg M, Hunt R, Tarnow-Mordi WO, Inder TE, Davis PG. Cooling for newborns with hypoxic ischaemic encephalopathy. Cochrane Database of Systematic Reviews 2013, Issue 1. [DOI: 10.1002/14651858.CD003311.pub3; PUBMED: 23440789]

\section{Jones 2009}

Jones CA, Walker KS, Badawi N. Antiviral agents for treatment of herpes simplex virus infection in neonates. Cochrane Database of Systematic Reviews 2009, Issue 3. [DOI: 10.1002/14651858.CD004206.pub2; PUBMED: 19588350]

\section{Kamlin 2003}

Kamlin COF, Davis PG. Long versus short inspiratory times in neonates receiving mechanical ventilation. Cochrane Database of Systematic Reviews 2004, Issue 4. [DOI: 10.1002/14651858.CD004503.pub2; PUBMED: 15495117]

\section{Moe-Byrne 2016}

Moe-Byrne T, Brown JVE, McGuire W. Glutamine supplementation to prevent morbidity and mortality in preterm infants. Cochrane Database of Systematic Reviews 2016, Issue 4. [DOI: 10.1002/14651858.CD001457.pub6; PUBMED: 27089158]

\section{More 2016}

More K, Athalye-Jape GK, Rao SC, Patole SK. Endothelin receptor antagonists for persistent pulmonary hypertension in term and late preterm infants. Cochrane Database of Systematic Reviews 2016, Issue 8. [DOI: 10.1002/14651858.CD010531.pub2; PUBMED: 27535894]

\section{Ohlsson 2014}

Ohlsson A, Aher SM. Early erythropoietin for preventing red blood cell transfusion in preterm and/or low birth weight infants. Cochrane Database of Systematic Reviews 2014, Issue 4. [DOI: 10.1002/14651858.CD004863.pub4; PUBMED: 24771408]

\section{Ohlsson 2015}

Ohlsson A, Walia R, Shah SS. Ibuprofen for the treatment of patent ductus arteriosus in preterm or low birth weight (or both) infants. Cochrane Database of Systematic Reviews 2015, Issue 2. [DOI: 10.1002/14651858.CD003481.pub6; PUBMED: 25692606]

\section{Okwundu 2012}

Okwundu Cl, Okoromah CAN, Shah PS. Prophylactic phototherapy for preventing jaundice in preterm or low birth weight infants. Cochrane Database of Systematic Reviews 2012, Issue 1. [DOI: 10.1002/14651858.CD007966.pub2; PUBMED: 22258977]

\section{Osborn 2001}

Osborn DA. Thyroid hormones for preventing neurodevelopmental impairment in preterm infants. Cochrane Database of Systematic Reviews 2001, Issue 4. [DOI: 10.1002/14651858.CD001070; PUBMED: 11687092]

\section{Osborn 2004}

Osborn DA, Evans NJ. Early volume expansion for prevention of morbidity and mortality in very preterm infants. Cochrane Database of Systematic Reviews 2004, Issue 2. [DOI: 10.1002/14651858.CD002055.pub2; PUBMED: 15106166]

\section{Osborn 2007}

Osborn DA, Hunt R. Prophylactic postnatal thyroid hormones for prevention of morbidity and mortality in preterm infants. Cochrane Database of Systematic Reviews 2007, Issue 1. [DOI: 10.1002/14651858.CD005948.pub2; PUBMED: 17253571]

\section{Osborn 2007b}

Osborn DA, Paradisis M, Evans NJ. The effect of inotropes on morbidity and mortality in preterm infants with low systemic or organ blood flow. Cochrane Database of Systematic Reviews 2007, Issue 1. [DOI: 10.1002/14651858.CD005090.pub2; PUBMED: 17253539$]$

\section{Seger 2009}

Seger N, Soll R. Animal derived surfactant extract for treatment of respiratory distress syndrome. Cochrane Database of Systematic Reviews 2009, Issue 2. [DOI: 10.1002/14651858.CD007836; PUBMED: 19370695]

\section{Shah 2007}

Shah PS, Shah VS. Arginine supplementation for prevention of necrotising enterocolitis in preterm infants. Cochrane Database of Systematic Reviews 2007, Issue 3. [DOI: 10.1002/14651858.CD004339.pub3; PUBMED: 17636753]

\section{Shah 2012}

Shah VS, Ohlsson A, Halliday HL, Dunn M. Early administration of inhaled corticosteroids for preventing chronic lung disease in ventilated very low birth weight preterm neonates. Cochrane Database of Systematic Reviews 2012, Issue 5. [DOI: 10.1002/14651858.CD001969.pub3; PUBMED: 22592680]

\section{Smit 2013}

Smit E, Odd D, Whitelaw A. Postnatal phenobarbital for the prevention of intraventricular haemorrhage in preterm infants. Cochrane Database of Systematic Reviews 2013, Issue 8. [DOI: 10.1002/14651858.CD001691.pub3; PUBMED: 23943189]

\section{Soll 2000}

Soll R. Synthetic surfactant for respiratory distress syndrome in preterm infants. Cochrane Database of Systematic Reviews 2000, Issue 2. [DOI: 10.1002/14651858.CD001149; PUBMED: 10796417]

\section{Soll 2010}

Soll R, Özek E. Prophylactic protein free synthetic surfactant for preventing morbidity and mortality in preterm infants. Cochrane Database of Systematic Reviews 2010, Issue 1. [DOI: 10.1002/14651858.CD001079.pub2; PUBMED: 20091513]

\section{Spittle 2015}

Spittle A, Orton J, Anderson PJ, Boyd R, Doyle LW. Early developmental intervention programmes provided post hospital discharge to prevent motor and cognitive impairment in preterm infants. Cochrane Database of Systematic Reviews 
2015, Issue 11. [DOI: 10.1002/14651858.CD005495.pub4; PUBMED: 26597166]

\section{Tan 2005}

Tan A, Schulze AA, O'Donnell CPF, Davis PG. Air versus oxygen for resuscitation of infants at birth. Cochrane Database of Systematic Reviews 2005, Issue 2. [DOI: 10.1002/14651858.CD002273.pub3; PUBMED: 15846632]

\section{Weston 2016}

Weston PJ, Harris DL, Battin M, Brown J, Hegarty JE, Harding JE. Oral dextrose gel for the treatment of hypoglycaemia in newborn infants. Cochrane Database of Systematic Reviews 2016, Issue 5. [DOI: 10.1002/14651858.CD011027.pub2; PUBMED: 27142842]

\section{Wheeler 2010}

Wheeler K, Klingenberg C, McCallion N, Morley CJ, Davis PG. Volume-targeted versus pressure-limited ventilation in the neonate. Cochrane Database of Systematic Reviews 2010, Issue 11. [DOI: 10.1002/14651858.CD003666.pub3; PUBMED: 21069677]

\section{Whyte 2011}

Whyte R, Kirpalani H. Low versus high haemoglobin concentration threshold for blood transfusion for preventing morbidity and mortality in very low birth weight infants. Cochrane Database of Systematic Reviews 2011, Issue 11. [DOI: 10.1002/14651858.CD000512.pub2; PUBMED: 22071798]

\section{Young 2016}

Young L, Berg M, Soll R. Prophylactic barbiturate use for the prevention of morbidity and mortality following perinatal asphyxia. Cochrane Database of Systematic Reviews 2016, Issue 5. [DOI: 10.1002/14651858.CD001240.pub3; PUBMED: 27149645]

\section{References to excluded reviews}

\section{Atherton 2012}

Atherton H, Sawmynaden P, Sheikh A, Majeed A, Car J. Email for clinical communication between patients/caregivers and healthcare professionals. Cochrane Database of Systematic Reviews 2012, Issue 11. [DOI: 10.1002/14651858.CD007978.pub2; PUBMED: 23152249]

\section{Barlow 2015}

Barlow J, Bennett C, Midgley N, Larkin SK, Wei Y. Parent-infant psychotherapy for improving parental and infant mental health. Cochrane Database of Systematic Reviews 2015, Issue 1. [DOI: 10.1002/14651858.CD010534.pub2; PUBMED: 25569177]

\section{Bredemeyer 2012}

Bredemeyer SL, Foster JP. Body positioning for spontaneously breathing preterm infants with apnoea. Cochrane Database of Systematic Reviews 2012, Issue 6. [DOI: 10.1002/14651858.CD004951.pub2; PUBMED: 22696346]

\section{Brown 2016}

Brown JVE, Meader N, Cleminson J, McGuire W. C-reactive protein for diagnosing late-onset infection in newborn infants.
Cochrane Database of Systematic Reviews 2016, Issue 3. [DOI: 10.1002/14651858.CD012126]

\section{Carr 2003}

Carr R, Modi N, Doré CJ. G-CSF and GM-CSF for treating or preventing neonatal infections. Cochrane Database of Systematic Reviews 2003, Issue 3. [DOI: 10.1002/14651858.CD003066; PUBMED: 12917944]

\section{Davis 2001}

Davis PG, Henderson-Smart DJ. Intravenous dexamethasone for extubation of newborn infants. Cochrane

Database of Systematic Reviews 2001, Issue 4. [DOI:

10.1002/14651858.CD000308; PUBMED: 11687075]

\section{Ethawi 2016}

Ethawi YH, Abou Mehrem A, Minski J, Ruth CA, Davis PG. High frequency jet ventilation versus high frequency oscillatory ventilation for pulmonary dysfunction in preterm infants. Cochrane Database of Systematic Reviews 2016, Issue 5. [DOI: 10.1002/14651858.CD010548.pub2; PUBMED: 27149997]

\section{Hancock 2013}

Hancock EC, Osborne JP, Edwards SW. Treatment of infantile spasms. Cochrane Database of Systematic Reviews 2013, Issue 6. [DOI: 10.1002/14651858.CD001770.pub3; PUBMED: 23740534]

\section{Jones 2003}

Jones CA, Walker KS, Henderson-Smart DJ. Antiviral therapy for symptomatic congenital cytomegalovirus infection in neonates and infants up to 3 months of age. Cochrane Database of Systematic Reviews 2003, Issue 3. [DOI: 10.1002/14651858.CD004340]

\section{Lewin 2010}

Lewin S, Munabi-Babigumira S, Glenton C, Daniels K, Bosch-Capblanch X, van Wyk BE, et al. Lay health workers in primary and community health care for maternal and child health and the management of infectious diseases. Cochrane Database of Systematic Reviews 2010, Issue 3. [DOI: 10.1002/14651858.CD004015.pub3; PUBMED: 20238326]

\section{Malviya 2013}

Malviya MN, Ohlsson A, Shah SS. Surgical versus medical treatment with cyclooxygenase inhibitors for symptomatic patent ductus arteriosus in preterm infants. Cochrane Database of Systematic Reviews 2013, Issue 3. [DOI: 10.1002/14651858.CD003951.pub3; PUBMED: 23543527]

\section{Morag 2016}

Morag I, Ohlsson A. Cycled light in the intensive care unit for preterm and low birth weight infants. Cochrane Database of Systematic Reviews 2016, Issue 8. [DOI: 10.1002/14651858.CD006982.pub4; PUBMED: 27508358]

\section{Okwundu 2014}

Okwundu Cl, Uthman OA, Smith J. Transcutaneous screening for hyperbilirubinemia in neonates. Cochrane Database of Systematic Reviews 2014, Issue 4. [DOI: 10.1002/14651858.CD011060] 


\section{Pammi 2011}

Pammi M, Brocklehurst P. Granulocyte transfusions for neonates with confirmed or suspected sepsis and neutropenia. Cochrane Database of Systematic Reviews 2011, Issue 10. [DOI: 10.1002/14651858.CD003956.pub2; PUBMED: 21975741]

\section{Pammi 2015}

Pammi M, Flores A, Versalovic J, Leeflang MMG. Molecular assays for the diagnosis of sepsis in neonates. Cochrane Database of Systematic Reviews 2015, Issue 11. [DOI: 10.1002/14651858.CD011926]

\section{Pammi 2015b}

Pammi M, Haque KN. Pentoxifylline for treatment of sepsis and necrotizing enterocolitis in neonates. Cochrane Database of Systematic Reviews 2015, Issue 3. [DOI: 10.1002/14651858.CD004205.pub3; PUBMED: 25751631]

\section{Scholefield 2013}

Scholefield B, Duncan H, Davies P, Gao Smith F, Khan K, et al. Hypothermia for neuroprotection in children after cardiopulmonary arrest. Cochrane Database of Systematic Reviews 2013, Issue 2. [DOI: 10.1002/14651858.CD009442.pub2; PUBMED: 23450604]

\section{Shah 2012b}

Shah SS, Ohlsson A, Shah VS. Intraventricular antibiotics for bacterial meningitis in neonates. Cochrane Database of Systematic Reviews 2012, Issue 7. [DOI: 10.1002/14651858.CD004496.pub3; PUBMED: 22786491]

\section{Suresh 2003}

Suresh G, Martin CL, Soll R. Metalloporphyrins for treatment of unconjugated hyperbilirubinemia in neonates. Cochrane Database of Systematic Reviews 2003, Issue 2. [DOI: 10.1002/14651858.CD004207; PUBMED: 12804504 ]

\section{Thukral 2015}

Thukral A, Deorari A, Chawla D. Periodic change of body position under phototherapy in term and late preterm neonates with hyperbilirubinemia. Cochrane Database of Systematic Reviews 2015, Issue 12. [DOI: 10.1002/14651858.CD011997]

\section{Upadhyay 2016}

Upadhyay A, Chawla D, Joshi P, Davis PG. Short-duration versus standard-duration antibiotic regimens for the treatment of neonatal bacterial infection. Cochrane Database of Systematic Reviews 2016, Issue 1. [DOI: 10.1002/14651858.CD012063]

\section{Ward 2003}

Ward MC, Sinn J. Steroid therapy for meconium aspiration syndrome in newborn infants. Cochrane Database of Systematic Reviews 2003, Issue 4. [DOI: 10.1002/14651858.CD003485; PUBMED: 14583981]

\section{Whitelaw 2001}

Whitelaw A, Brion LP, Kennedy CR, Odd D. Diuretic therapy for newborn infants with posthemorrhagic ventricular dilatation. Cochrane Database of Systematic Reviews 2001, Issue 2. [DOI: 10.1002/14651858.CD002270; PUBMED: 11406041]

\section{Whitelaw 2001b}

Whitelaw A. Repeated lumbar or ventricular punctures in newborns with intraventricular hemorrhage. Cochrane Database of Systematic Reviews 2001, Issue 1. [DOI: 10.1002/14651858.CD000216; PUBMED: 11279684]

\section{Woodgate 2001}

Woodgate PG, Davies MW. Permissive hypercapnia for the prevention of morbidity and mortality in mechanically ventilated newborn infants. Cochrane Database of Systematic Reviews 2001, Issue 2. [DOI: 10.1002/14651858.CD002061; PUBMED: 11406029$]$

\section{Additional references}

\section{AAP 2014}

American Academy of Pediatrics. Clinical report: hypothermia and neonatal encephalopathy. Pediatrics 2014;133(6):1146-50. [DOI: 10.1542/peds.2014-0899]

\section{Access Economics 2008}

Access Economics. The Economic Impact of Cerebral Palsy in Australia in 2007. Sydney: Cerebral Palsy Australia, 2008.

\section{ACPR Group 2013}

Australian Cerebral Palsy Register (ACPR) Group. Report of the Australian Cerebral Palsy Register, Birth Years 1993-2006. ACPR Group: Sydney, 2013.

\section{Badawi 2005}

Badawi N, Felix JF, Kurinczuk JJ, Dixon G, Watson L, Keogh JM, et al. Cerebral palsy following term newborn encephalopathy: a population-based study. Developmental Medicine and Child Neurology 2005;47(5):293-8. [PUBMED: 15892370]

\section{Blair 1988}

Blair E, Stanley FJ. Intrapartum asphyxia: a rare cause of cerebral palsy. Journal of Pediatrics 1988;112(4):515-9. [PUBMED: 3351675]

\section{Blair 2001}

Blair E, Watson L, Badawi N, Stanley FJ. Life expectancy among people with cerebral palsy in Western Australia. Developmental Medicine and Child Neurology 2001;43(8):508-15. [PUBMED: 11508916]

\section{Blair 2006}

Blair E, Watson L. Epidemiology of cerebral palsy. Seminars in Fetal \& Neonatal Medicine 2006;11(2):117-25. [DOI: 10.1016/ j.siny.2005.10.010; PUBMED: 16338186]

\section{Bosanquet 2013}

Bosanquet M, Copeland L, Ware R, Boyd R. A systematic review of tests to predict cerebral palsy in young children. Developmental Medicine and Child Neurology 2013;55(5):418-26. [DOI: 10.1111/dmcn.12140; PUBMED: 23574478]

\section{Cans 2000}

Cans C. Surveillance of cerebral palsy in Europe: a collaboration of cerebral palsy surveys and registers. Developmental Medicine 
and Child Neurology 2000;42(12):816-24. [DOI: 10.1111/

j.1469-8749.2000.tb00695.x; PUBMED: 11132255]

\section{Cans 2004}

Cans C, McManus V, Crowley M, Guillem P, Platt MJ, Johnson A, et al. Cerebral palsy of post-neonatal origin: characteristics and risk factors. Paediatric and Perinatal Epidemiology 2004;18(3):214-20. [DOI: 10.1111/j.1365-3016.2004.00559.x; PUBMED: 15130161]

\section{CDC 2004}

Centers for Disease Control and Prevention (CDC). Economic costs associated with mental retardation, cerebral palsy, hearing loss, and vision impairment - United States, 2003. Morbidity and Mortality Weekly Report 2004;53(3):57-9. [PUBMED: 14749614]

\section{Colver 2012}

Colver A. Outcomes for people with cerebral palsy: life expectancy and quality of life. Paediatrics and Child Health 2012;22(9):384-7. [DOI: 10.1016/j.paed.2012.03.003]

\section{Covidence 2015}

Covidence. About Covidence. www.covidence.org (accessed 17 May 2015).

\section{Davis 2010}

Davis E, Shelly A, Waters E, Boyd R, Cook K, Davern M. The impact of caring for a child with cerebral palsy: quality of life for mothers and fathers. Child: Care, Health and Development 2010;36(1):63-73. [DOI: 10.1111/j.1365-2214.2009.00989.x; PUBMED: 19702639]

\section{Dixon 2002}

Dixon G, Badawi N, Kurinczuk JJ, Keogh JM, Silburn SR, Zubrick SR. Early developmental outcomes after newborn encephalopathy. Pediatrics 2002;109(1):26-33. [PUBMED: 11773538]

\section{Doyle 2009}

Doyle LW, Crowther CA, Middleton P, Marret S, Rouse D. Magnesium sulphate for women at risk of preterm birth for neuroprotection of the fetus. Cochrane Database of Systematic Reviews 2009, Issue 1. [DOI: 10.1002/14651858.CD004661.pub3; PUBMED: 19160238 ]

\section{Drougia 2007}

Drougia A, Giapros V, Krallis N, Theocharis P, Nikaki A, Tzoufi M. Incidence and risk factors for cerebral palsy in infants with perinatal problems: a 15-year review. Early Human Development 2007;83(8):541-7. [PUBMED: 10.1016/j.earlhumdev.2006.10.004; PUBMED: 17188824$]$

\section{Ellenberg 2013}

Ellenberg JH, Nelson KB. The association of cerebral palsy with birth asphyxia: a definitional quagmire. Developmental Medicine and Child Neurology 2013;55(3):210-6. [DOI: 10.1111/ dmcn.12016; PUBMED: 23121164]

\section{Farquhar 2015}

Farquhar C, Rishworth JR, Brown J, Nelen WLDM, Marjoribanks J. Assisted reproductive technology: an overview of Cochrane Reviews. Cochrane Database of Systematic Reviews 2015, Issue 7. [DOI: 10.1002/14651858.CD010537.pub4; PUBMED: 26174592

\section{Germany 2013}

Germany L, Ehlinger V, Klapouszczak D, Delobel M, Hollódy K, Sellier E, et al. Trends in prevalence and characteristics of postneonatal cerebral palsy cases: a European registry-based study. Research in Developmental Disabilities 2013;34(5):1669-77. [DOI: 10.1016/j.ridd.2013.02.016; PUBMED: 23500161]

\section{Hadders-Algra 2016}

Hadders-Algra M, Boxum AG, Hielkema T, Hamer EG. Effect of early intervention in infants at very high risk of cerebral palsy: a systematic review. Developmental Medicine and Child Neurology 2017; Vol. 59, issue 3:246-58. [DOI: 10.1111/ dmcn.13331; PUBMED: 27925172]

\section{Hemming 2005}

Hemming K, Hutton JL, Colver A, Platt M-J. Regional variation in survival of people with cerebral palsy in the United Kingdom. Pediatrics 2005;116(6):1383-90. [DOI: 10.1542/peds.2005-0259; PUBMED: 16322162]

\section{Higgins 2011}

Higgins JPT, Green S, editors. Cochrane Handbook for Systematic Reviews of Interventions Version 5.1.0 (updated March 2011). The Cochrane Collaboration, 2011. Available from handbook.cochrane.org.

\section{Himpens 2008}

Himpens E, Van den Broeck C, Oostra A, Calders P, Vanhaesebrouck P. Prevalence, type, distribution, and severity of cerebral palsy in relation to gestational age: a metaanalytic review. Developmental Medicine and Child Neurology 2008;50(5):334-40. [DOI: 10.1111/j.1469-8749.2008.02047.x; PUBMED: 18355333]

\section{Jacobsson 2004}

Jacobsson B, Hagberg G. Antenatal risk factors for cerebral palsy. Best Practice \& Research. Clinical Obstetrics \& Gynaecology 2004;18(3):425-36. [DOI: 10.1016/j.bpobgyn.2004.02.011; PUBMED: 15183137$]$

\section{Jones 2012}

Jones L, Othman M, Dowswell T, Alfirevic Z, Gates S, Newburn $M$, et al. Pain management for women in labour: an overview of systematic reviews. Cochrane Database of Systematic Reviews 2012, Issue 3. [DOI: 10.1002/14651858.CD009234.pub2; PUBMED: 22419342]

\section{Kruse 2009}

Kruse M, Michelsen SI, Flachs EM, Brønnum-Hansen H, Madsen M, Uldall P. Lifetime costs of cerebral palsy. Developmental Medicine and Child Neurology 2009;51(8):622-8. [DOI: 10.1111/j.1469-8749.2008.03190.x; PUBMED: 19416329] 


\section{Lassi 2015}

Lassi ZS, Middleton PF, Crowther C, Bhutta ZA. Interventions to improve neonatal health and later survival: an overview of systematic reviews. EBioMedicine 2015;2(8):985-1000. [DOI: 10.1016/j.ebiom.2015.05.023; PUBMED: 26425706]

\section{MacLennan 2015}

MacLennan AH, Thompson SC, Gecz J. Cerebral palsy: causes, pathways, and the role of genetic variants. American Journal of Obstetrics and Gynecology 2015; Vol. 213, issue 6:779-88. [DOI: 10.1016/j.ajog.2015.05.034; PUBMED: 26003063]

\section{McIntyre 2010}

McIntyre S, Novak I, Cusick A. Consensus research priorities for cerebral palsy: a Delphi survey of consumers, researchers, and clinicians. Developmental Medicine and Child Neurology 2010;52(3):270-5. [DOI: 10.1111/j.1469-8749.2009.03358.x; PUBMED: 19694780]

\section{McIntyre 2011}

McIntyre S, Morgan C, Walker K, Novak I. Cerebral palsy don't delay. Developmental Disabilities Research Reviews 2011;17(2):114-29. [DOI: 10.1002/ddrr.1106; PUBMED: 23362031]

\section{McIntyre 2013}

McIntyre S, Taitz D, Keogh J, Goldsmith S, Badawi N, Blair E. A systematic review of risk factors for cerebral palsy in children born at term in developed countries. Developmental Medicine and Child Neurology 2013;55(6):499-508. [DOI: 10.1111/ dmcn.12017; PUBMED: 23181910]

\section{Moreno-De-Luca 2012}

Moreno-De-Luca A, Ledbetter D, Martin C. Genetic insights into the causes and classification of cerebral palsies. Lancet Neurology 2012;11(3):283-92. [DOI: 10.1016/ S1474-4422(11)70287-3; PUBMED: 22261432]

\section{Morgan 2016}

Morgan C, Crowle C, Goyen T-A, Hardman C, Jackman M, Novak I, et al. Sensitivity and specificity of General Movements Assessment for diagnostic accuracy of detecting cerebral palsy early in an Australian context. Journal of Paediatrics and Child Health 2016;52(1):54-9. [DOI: 10.1111/jpc.12995; PUBMED: 26289780]

\section{Morris 2007}

Morris C. Definition and classification of cerebral palsy: a historical perspective. Developmental Medicine and Child Neurology 2007;109:3-7. [PUBMED: 17370476]

\section{Murphy 1997}

Murphy DJ, Hope PL, Johnson A. Neonatal risk factors for cerebral palsy in very preterm babies: case-control study. British Medical Journal 1997;8(314):404-8. [PUBMED: 9040385]

\section{Mutch 1992}

Mutch L, Alberman E, Hagberg B, Kodama K, Perat MV. Cerebral palsy epidemiology: where are we now and where are we going?. Developmental Medicine and Child Neurology 1992;34(6):547-51. [PUBMED: 1612216]

\section{Nelson 2008}

Nelson KB. Causative factors in cerebral palsy. Clinical Obstetrics and Gynecology 2008;51(4):749-62. [DOI: 10.1097/ GRF.0b013e318187087c; PUBMED: 18981800]

\section{Novak 2012}

Novak I, Hines M, Goldsmith S, Barclay R. Clinical prognostic messages from a systematic review on cerebral palsy. Pediatrics 2012;130(5):e1285-312. [DOI: 10.1542/peds.2012-0924; PUBMED: 23045562]

\section{Oskoui 2013}

Oskoui M, Coutinho F, Dykeman J, Jetté N, Pringsheim T. An update on the prevalence of cerebral palsy: a systematic review and meta-analysis. Developmental Medicine and Child Neurology 2013;55(6):509-19. [DOI: 10.1111/dmcn.12080; PUBMED: 23346889]

\section{Oskoui 2015}

Oskoui M, Gazzellone MJ, Thiruvahindrapuram B, Zarrei M, Andersen J, Wei J, et al. Clinically relevant copy number variations detected in cerebral palsy. Nature Communications 2015;6:7949. [DOI: 10.1038/ncomms8949; PUBMED: 26236009]

\section{O'Callaghan 2009}

O'Callaghan ME, MacLennan AH, Haan EA, Dekker G, South Australian Cerebral Palsy Research Group. The genomic basis of cerebral palsy: a HuGE systematic literature review. Human Genetics 2009;126(1):149-72. [DOI: 10.1007/s00439-009-0638-5; PUBMED: 19238444]

\section{O'Shea 2008}

O'Shea TM. Diagnosis, treatment, and prevention of cerebral palsy in near-term/term infants. Clinics in Obstetrics and Gynaecology 2008;51(4):816-28. [DOI: 10.1097/ GRF.0b013e3181870ba7; PUBMED: 18981805]

\section{Reid 2012}

Reid SM, Carlin JB, Reddihough DS. Survival of individuals with cerebral palsy born in Victoria, Australia, between 1970 and 2004. Developmental Medicine and Child Neurology 2012;54(4):353-60. [DOI: 10.1111/j.1469-8749.2012.04218.x; PUBMED: 22329739]

\section{Reid 2015}

Reid S, Meehan E, Mclntyre S, Goldsmith S, Badawi N, Reddihough D. Temporal trends in cerebral palsy by impairment severity and birth gestation. Developmental Medicine and Child Neurology 2016; Vol. 58, issue Suppl 2:25-35. [DOI: 10.1111/ dmcn.13001; PUBMED: 26762733]

\section{RevMan 2014 [Computer program]}

Nordic Cochrane Centre, The Cochrane Collaboration. Review Manager 5 (RevMan5). Version 5.3. Copenhagen: Nordic Cochrane Centre, The Cochrane Collaboration, 2014.

\section{Robertson 2012}

Robertson NJ, Tan S, Groenendaal F, van Bel F, Juul SE, Bennet $\mathrm{L}$, et al. Which neuroprotective agents are ready for bench to bedside translation in the newborn infant? 
Journal of Pediatrics 2012;160(4):544-52.e4. [DOI: 10.1016/ j.jpeds.2011.12.052; PUBMED: 22325255]

\section{Rosenbaum 2007}

Rosenbaum P, Paneth N, Leviton A, Goldstein M, Bax M, Damiano D, et al. A report: the definition and classification of cerebral palsy April 2006. Developmental Medicine and Child Neurology 2007;109:8-14. [PUBMED: 17370477]

\section{Sellier 2015}

Sellier E, Platt MJ, Andersen GL, Krägeloh-Mann I, De La Cruz J, Cans C, et al. Decreasing prevalence in cerebral palsy: a multi-site European population-based study, 1980 to 2003. Developmental Medicine and Child Neurology 2016; Vol. 58, issue 1:85-92. [DOI: 10.1111/dmcn.12865; PUBMED: 26330098]

\section{Shea 2009}

Shea BJ, Hamel C, Wells GA, Bouter LM, Kristjansoon E, Grimshaw J, et al. AMSTAR is a reliable and valid measurement tool to assess the methodological quality of systematic reviews. Journal of Clinical Epidemiology 2009;62(10):1013-20. [DOI: 10.1016/j.jclinepi.2008.10.009; PUBMED: 19230606]

\section{Shepherd 2016}

Shepherd E, Middleton P, Makrides M, McIntyre SJ, Badawi N, Crowther CA. Antenatal and intrapartum interventions for preventing cerebral palsy: an overview of Cochrane systematic reviews. Cochrane Database of Systematic Reviews 2016, Issue 2. [DOI: 10.1002/14651858.CD012077]

\section{Smithers-Sheedy 2014}

Smithers-Sheedy H, Badawi N, Blair E, Cans C, Himmelmann K, Krägeloh-Mann I, et al. What constitutes cerebral palsy in the twenty-first century?. Developmental Medicine and Child Neurology 2014;56(4):323-8. [DOI: 10.1111/dmcn.12262; PUBMED: 24111874]

\section{Tran 2005}

Tran U, Gray PH, O'Callaghan MJ. Neonatal antecedents for cerebral palsy in extremely preterm babies and interaction with maternal factors. Early Human Development 2005;81(6):555-61. [DOI: 10.1016/j.earlhumdev.2004.12.009; PUBMED: 15935933]

\section{Walstab 2004}

Walstab JE, Bell RJ, Reddihough DS, Brennecke SP, Bessell CK, Beischer NA. Factors identified during the neonatal period associated with risk of cerebral palsy. Australian \& New Zealand Journal of Obstetrics \& Gynaecology 2004;44(3):342-6. [DOI: 10.1111/j.1479-828X.2004.00249.x; PUBMED: 15282008]

\section{Whiting 2015}

Whiting P, Savović J, Higgins JP, Caldwell DM, Reeves BC, Shea B, et al. ROBIS: a new tool to assess risk of bias in systematic reviews was developed. Journal of Clinical Epidemiology 2016; Vol. 69:225-34. [DOI: 10.1016/ j.jclinepi.2015.06.005; PUBMED: 26092286]

\section{ADDITIONAL TABLES}

Table 1. Characteristics of excluded reviews

\section{Review ID and title Reason for exclusion}

Atherton 2012

Email for clinical communication between patients/caregivers and healthcare professionals
Wrong participants (not neonates):

1. "We included all healthcare professionals, patients and caregivers regardless of age, gender and ethnicity. We considered participants originating the email communication, receiving the email communication and copied into the email communication"

\section{Barlow 2015}

Parent-infant psychotherapy for improving parental and infant mental health
Wrong participants (not neonates):

1. "We included studies involving parent-infant dyads in which the parent was experiencing mental health problems, domestic abuse or substance dependency, with or without the infant showing signs of attachment or dysregulation problems, or both attachment and dysregulation problems. We included all infants irrespective of the presence of problems such as low birthweight, prematurity or disabilities. We included studies targeting infants and toddlers in which the mean age of the infant participants was 24 months or less at the point of referral. We included studies targeting all parents (i.e. including fathers, birth parents, adoptive and kinship parents, but not foster parents)"
Bredemeyer 2012

Body positioning for spontaneously breathing preterm infants with apnoea

\section{Secondary outcomes pre-specified include the following:}

1. Short-term motor development up to about 12 months' corrected age, as measured by a validated assessment tool

2. Longer-term motor development up to about 2 years' corrected age, as measured by a validated assessment tool

3. Neurodevelopment assessed at about 2 years' corrected age, as measured by a validated assessment tool 
Table 1. Characteristics of excluded reviews (Continued)

No outcome data for these outcomes

\author{
Brown 2016 \\ C-reactive protein for diagnos- \\ ing late-onset infection in new- \\ born infants
}

Protocol for diagnostic test accuracy review

\section{Carr 2003}

G-CSF and GM-CSF for treating or preventing neonatal infections

Secondary outcomes pre-specified include:

1. Long-term outcomes: death and disability at or $>1$ year from birth

No outcome data for cerebral palsy (single study results reported "cognition, language and social developmental performance scores were within the normal range for age and motor deficits were 'typical of high-risk, low birth weight neonates'. However there was no comparison made between G-CSF and control infants"

\section{Davis 2001}

No pre-specified outcome focused on development/disability at follow-up

Intravenous dexamethasone for extubation of newborn infants

\section{Ethawi 2016 \\ High-frequency jet ventilation vs high-frequency oscillatory ventilation for pulmonary dys- function in preterm infants}

Secondary neonatal outcomes pre-specified include:

1. Neurodevelopmental outcomes including motor, mental, and sensory outcomes at 2 years of age (study author defined)

No outcome data for this outcome (no included trials)

\section{Hancock 2013}

Treatment of infantile spasms

\section{Outcomes pre-specified include:}

1. Long-term psychomotor development

No outcome data for cerebral palsy (single-study results reported related to BSID; VABS; 'cognitive development'; Japanese Tumor Scale; DDST)

\section{Jones 2003}

Antiviral therapy for symptomatic congenital cytomegalovirus infection in neonates and infants up to 3 months of age

\section{Protocol}

Primary outcomes pre-specified include:

1. Mortality at 1 year of life and the presence of cognitive, developmental, audiological, motor, or visual impairment upon completion of therapy, at follow-up at 1 year of life, and in later childhood

\section{Lewin 2010}

No pre-specified outcome focused on development/disability at follow-up

Lay health workers in primary and community health care for maternal and child health and management of infectious diseases

\section{Malviya 2013}

Surgical vs medical treatment with cyclo-oxygenase inhibitors for symptomatic patent ductus arteriosus in preterm infants

\section{Secondary outcomes pre-specified include:}

1. Neurodevelopmental outcome (neurodevelopmental outcome assessed by a standardised and validated assessment tool, a child developmental specialist, or both) at any age (outcome data will be grouped at 6, 9, 12, 18, 24 months, if available)

No outcome data for this outcome 
Table 1. Characteristics of excluded reviews (Continued)

Cycled light in the intensive care 1. Long-term outcomes: growth and neurodevelopment, including visual and auditory outcomes unit for preterm and low birthweight infants

at any age as reported by study authors using standardised and validated tests

No outcome data for these outcomes

\section{Protocol}

\section{Okwundu 2014}

Transcutaneous screening for hyperbilirubinaemia in neonates

No pre-specified outcome focused on development/disability at follow-up

\section{Pammi 2011}

Granulocyte transfusions for neonates with confirmed or suspected sepsis and neutropaenia

Pammi 2015

Molecular assays for diagnosis of sepsis in neonates
Primary outcomes pre-specified include:

1. Neurological outcome at 1 year of age or later (neurodevelopmental outcome as assessed by any validated test)

No outcome data for this outcome

Protocol for diagnostic test accuracy review

\section{Pammi 2015b}

Pentoxifylline for treatment of sepsis and necrotising enterocolitis in neonates
Secondary outcomes pre-specified include:

1. Neurological outcome at 2 or more years of age (neurodevelopmental outcome as assessed by a validated test)

No outcome data for this outcome

\section{Scholefield 2013}

Hypothermia for neuroprotection in children after cardiopulmonary arrest
Primary outcomes pre-specified include:

1. Best neurological outcome at hospital discharge and within the first year as assessed by the Paediatric Cerebral Performance Category score and other validated outcome scores for use in children (e.g. VABS)

No outcome data for these outcomes (no included trials)

\section{Shah 2012}

Intraventricular antibiotics for bacterial meningitis in neonates
Secondary outcomes pre-specified include:

1. Neurodevelopmental outcome (neurodevelopmental outcome as assessed by a standardised and validated assessment tool or a child developmental specialist, or both) at any age (outcome data will be grouped at 12, 18, and 24 months, if available)

No outcome data for this outcome

\section{Suresh 2003}

Metalloporphyrins for treatment of unconjugated hyperbilirubinaemia in neonates

Outcomes pre-specified include:

1. Presence of neurodevelopmental sequelae (i.e. any sensory, motor, cognitive, psychological, or behavioural impairment reported on follow-up any time after the neonatal period)

2. Degree of such neurodevelopmental impairment (expressed as mean or median scores on tests of neurodevelopmental function performed any time after the neonatal period)

No outcome data for these outcomes

\section{Thukral 2015}

Periodic change of body position under phototherapy in term and late preterm neonates with hyperbilirubinaemia

\section{Protocol}

Secondary outcomes pre-specified include:

1. Incidence of BIND (proportion). BIND or subtle encephalopathy shall be defined as neurological, cognitive, learning, or movement disorders; isolated hearing loss; or auditory dysfunction in 
Table 1. Characteristics of excluded reviews (Continued)

the presence of hyperbilirubinaemia (Bergman 1985; Hyman 1969; Johnson 1974; Rubin 1979; Scheldt 1977)

\section{Upadhyay 2016}

Short-duration vs standard-duration antibiotic regimens for treatment of neonatal bacterial infection

\section{Protocol}

Secondary outcomes pre-specified include:

1. Survival without major disability at 18 to 24 months' corrected age (proportion)
Ward $2003 \quad$ Primary outcomes pre-specified include:

Steroid therapy for meconium aspiration syndrome in newborn infants validated assessment tools
1. Long-term growth and neurodevelopmental outcomes assessed at age 1, 2, and 5 years with

No outcome data for this outcome
Whitelaw 2001

Diuretic therapy for newborn infants with post-haemorrhagic ventricular dilatation
Outcomes pre-specified include:

1. Moderate to severe long-term motor disability at 1 to 3 years of age

2. Combined outcome: death or (moderate to severe) long-term disability at 1 to 3 years of age

Data reported for these outcomes; no outcome data for cerebral palsy. "The larger trial showed that acetazolamide and furosemide treatment resulted in a borderline increase in the risk for motor impairment at one year (RR 1.27, 95\% Cl 1.02 - 1.58; RD 0.16, 95\% Cl $0.02-0.31$ ), but did not significantly affect the risk for the combined outcome of delay, disability or motor impairment among survivors, or the risk of the combined outcome of death, delay, disability or impairment at one year"

\section{Whitelaw 2001b}

Repeated lumbar or ventricular punctures in newborns with intraventricular haemorrhage

\section{Outcomes pre-specified include:}

1. Surviving with major disability for 12 months or longer in survivors

2. Surviving with multiple neurodevelopmental impairments

Data reported for these outcomes; no outcome data for cerebral palsy. "The tables and figures show that none of the trials found a significant effect of CSF tapping on a) need for shunt b) death c) major disability in survivors d) multiple disability in survivors e) death or disability. Similarly, meta-analysis of the results of all included trials shows no significant effect of CSF tapping on any of these outcomes"

\section{Woodgate 2001}

Permissive hypercapnia for prevention of morbidity and mortality in mechanically ventilated newborn infants

\section{Outcomes pre-specified include:}

1. Neurodevelopmental outcome

No outcome data for this outcome

Abbreviations: BIND: bilirubin-induced neurological dysfunction; BSID: Bayley Scales of Infant Development; CI: confidence interval; CSF: cerebrospinal fluid; DDST: Denver Developmental Screening Test; G-CSF: granulocyte-colony stimulating factor; GM-CSF: granulocytemacrophage colony-stimulating factor; RD: risk difference; RR: risk ratio; VABS: Vineland Adaptive Behavior Scales.

Table 2. Characteristics of included reviews

\begin{tabular}{lllllll}
\hline $\begin{array}{l}\text { Review ID } \\
\text { and title }\end{array}$ & $\begin{array}{l}\text { Date of } \\
\text { search and } \\
\text { date as- }\end{array}$ & $\begin{array}{l}\text { No. included } \\
\text { trials (coun- } \\
\text { tries and }\end{array}$ & $\begin{array}{l}\text { No. partici- } \\
\text { pants in in- } \\
\text { cluded tri- }\end{array}$ & $\begin{array}{l}\text { Inclusion criteria } \\
\text { for 'Types of partici- } \\
\text { pants' }\end{array}$ & $\begin{array}{l}\text { Relevant } \\
\text { compari- }\end{array}$ & $\begin{array}{l}\text { Overview outcomes for which } \\
\text { data were reported (no. trials }\end{array}$ \\
publication & als & & son inter- & and participants) \\
ventions & & (no. trials
\end{tabular}


Table 2. Characteristics of included reviews (Continued)

and partic-

ipants)

\section{Neonatal care: asphyxia}

\begin{tabular}{|c|c|c|c|c|c|c|}
\hline $\begin{array}{l}\text { Chaudhari } \\
2012 \\
\text { Allopurinol } \\
\text { for prevent- } \\
\text { ing mor- } \\
\text { tality and } \\
\text { morbidity } \\
\text { in newborn } \\
\text { infants with } \\
\text { hypoxic-is- } \\
\text { chaemic } \\
\text { en- } \\
\text { cephalopa- } \\
\text { thy }\end{array}$ & $\begin{array}{l}\text { Searches: } \\
\text { March } 2012 \\
\text { Up-to-date: } \\
\text { 4 April } \\
2012\end{array}$ & $\begin{array}{l}3 \text { RCTs } \\
\text { (Countries: } \\
\text { Netherlands, } \\
\text { Turkey; } \\
\text { Published: } \\
\text { 1990s: } 1 \\
\text { RCT; 2000s: } 2 \\
\text { RCTs) }\end{array}$ & 114 infants & $\begin{array}{l}\text { Newborn infants } \\
\text { (> } 34 \text { weeks' gesta- } \\
\text { tion) with hypox- } \\
\text { ic-ischaemic en- } \\
\text { cephalopathy de- } \\
\text { fined as clinical evi- } \\
\text { dence of cardiores- } \\
\text { piratory or neuro- } \\
\text { logical depression } \\
\text { (Apgar score }<7 \text { at } 5 \\
\text { minutes and beyond } \\
\text { after birth) and/or } \\
\text { evidence of severe } \\
\text { metabolic acidosis in } \\
\text { intrapartum foetal, } \\
\text { umbilical arterial } \\
\text { cord, or very early } \\
\text { neonatal blood sam- } \\
\text { ples (pH }<7 \text { or base } \\
\text { deficit > } 12 \text { mmol/ } \\
\text { L), and/or clinical or } \\
\text { electro-encephalo- } \\
\text { graphic (multi-chan- } \\
\text { nel or amplitude } \\
\text { integrated) evi- } \\
\text { dence of neonatal } \\
\text { encephalopathy } \\
\text { (MacLennan 1999) }\end{array}$ & $\begin{array}{l}\text { Allopurinol } \\
\text { vs control } \\
\text { ( } 3 \text { RCTs, } 114 \\
\text { neonates) }\end{array}$ & $\begin{array}{l}\text { Severity of cerebral palsy } \\
\text { ("Severe quadriplegia in sur- } \\
\text { viving infants" ( } 3 \text { RCTs, } 73 \text { chil- } \\
\text { dren); reported as a primary } \\
\text { outcome) } \\
\text { Other composite outcome } \\
\text { that includes cerebral palsy } \\
\text { as a component ("Death or se- } \\
\text { vere neurodevelopmental dis- } \\
\text { ability in survivors" ( } 3 \text { RCTs, } 110 \\
\text { children); reported as a primary } \\
\text { outcome) }\end{array}$ \\
\hline
\end{tabular}

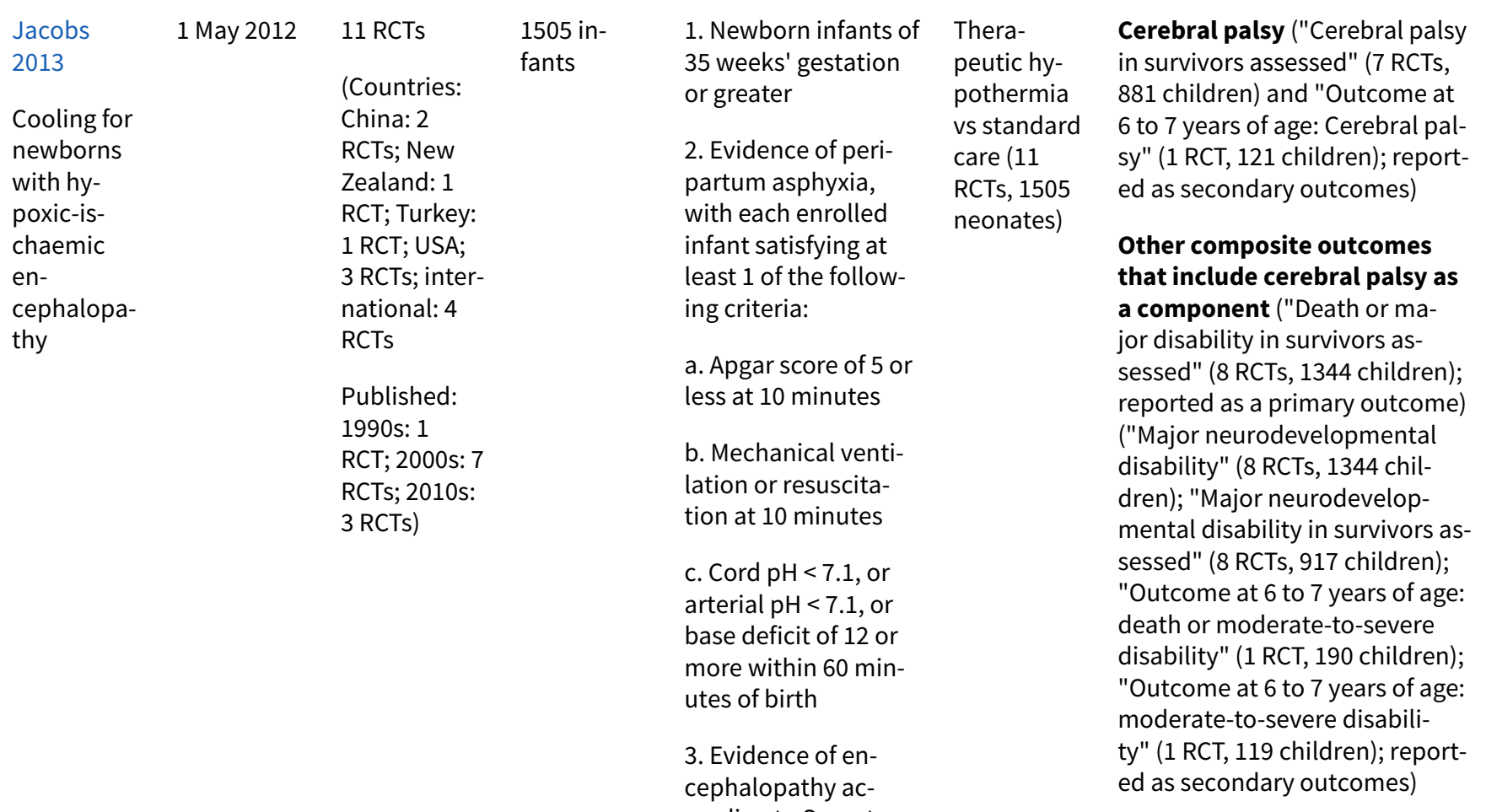


Table 2. Characteristics of included reviews (Continued)

staging (Finer 1981; Sarnat 1976):

a. Stage 1 (mild): hyperalertness, hyper-reflexia, dilated pupils, tachycardia, absence of seizures

b. Stage 2 (moderate): lethargy, hyper-reflexia, miosis, bradycardia, seizures, hypotonia with weak suck and Moro

c. Stage 3 (severe): stupor, flaccidity, small to mid position pupils that react poorly to light, decreased stretch reflexes, hypothermia, and absent Moro

No major congenital abnormalities recognisable at birth

\begin{tabular}{lll}
\hline Young 2016 & $\begin{array}{l}\text { 30 Novem- } \\
\text { ber } 2015\end{array}$ & 9 RCTs \\
Prophylac- & (Countries: \\
tic barbitu- & Finland: 1 \\
rate use for & RCT; India: \\
the preven- & 2 RCTs; Mex- \\
tion of mor- & ico: 1 RCT; \\
bidity and & Romania: 1 \\
mortality & RCT; South \\
following & Africa: 1 RCT; \\
perinatal & Spain: 1 RCT; \\
asphyxia & USA: 2 RCTs; \\
& \\
& Published: \\
& 1980s: 2 \\
& RCTs; $1990 \mathrm{~s}:$ \\
& 2 RCTs; \\
& 2000s: 2 \\
& RCTs; $2010 \mathrm{s:}$ \\
& 3 RCTs)
\end{tabular}

1. Term infants (37 weeks or greater) and late preterm infants (34 to $36+6$ weeks' gestation) 3 days of age or less with perinatal asphyxia

2. Evidence of perinatal asphyxia, characterised by evidence of neonatal or foetal distress with each enrolled infant satisfying at least 1 of the following criteria:

a. Cord gas or postnatal blood gas (within the first hour of life) with $\mathrm{pH} 7.0$ or less or base deficit $12 \mathrm{mEq} /$ $\mathrm{L}$ or greater

b. Apgar score 5 or less at 10 minutes
Motor dysfunction ("Neuromotor delay (BSID PDI more than 2 SD below mean) in survivors assessed" (6 RCTs, 657 children); reported as a secondary outcome)
Cerebral palsy ("Cerebral palsy" (2 RCTs, 69 children); reported as a secondary outcome) control $(8$ RCTs, 439 neonates)

Other composite outcomes that include cerebral palsy as a component ("Death or major neurodevelopmental disability" (1 RCT, 31 children); reported as a primary outcome) ("Major neurodevelopmental disability" (1 RCT, 31 children); reported as a secondary outcome) 
Table 2. Characteristics of included reviews (Continued)

c. Need for me-

chanical venti-

lation or resus-

citation at 10

minutes of life

3. With or without evidence of encephalopathy (moderate or severe) according to Sarnat staging (Sarnat 1976)

4. No evidence of seizures

5. No major congenital abnormalities recognisable at birth

Neonatal care: haemorrhage: periventricular/intraventricular

\begin{tabular}{|c|c|c|c|c|c|c|}
\hline $\begin{array}{l}\text { Hunt } 2010 \\
\text { Ethamsy- } \\
\text { late for the } \\
\text { preven- } \\
\text { tion of mor- } \\
\text { bidity and } \\
\text { mortality } \\
\text { in preterm } \\
\text { or very } \\
\text { low birth } \\
\text { weight in- } \\
\text { fants }\end{array}$ & $\begin{array}{l}\text { Search: } \\
24 \text { August } \\
2009 \\
\text { Up-to-date: } \\
22 \text { Septem- } \\
\text { ber } 2009\end{array}$ & $\begin{array}{l}7 \text { RCTs } \\
\text { (Countries: } \\
\text { France, } \\
\text { Greece, UK: } 1 \\
\text { RCT; India: } 1 \\
\text { RCT; Switzer- } \\
\text { land: } 1 \text { RCT; } \\
\text { Taiwan: } 1 \\
\text { RCT; Turkey: } \\
\text { 1 RCT; UK: } 2 \\
\text { RCTs; } \\
\text { Published: } \\
\text { 1980s: } 3 \\
\text { RCTs; 1990s: } \\
\text { 4 RCTs) }\end{array}$ & $\begin{array}{l}1410 \text { in- } \\
\text { fants }\end{array}$ & $\begin{array}{l}\text { Preterm infants born } \\
\text { before and including } \\
34 \text { weeks plus } 6 \text { days' } \\
\text { completed gestation } \\
\text { or with birthweight < } \\
2000 \mathrm{~g}\end{array}$ & $\begin{array}{l}\text { Etham- } \\
\text { sylate vs } \\
\text { placebo ( } 7 \\
\text { RCTs, } 1410 \\
\text { neonates) }\end{array}$ & $\begin{array}{l}\text { Cerebral palsy ("Cerebral pal- } \\
\text { sy in surviving children avail- } \\
\text { able for follow-up" ( } 3 \text { RCTs, } 532 \\
\text { children); reported as a primary } \\
\text { outcome) } \\
\text { Other composite outcomes } \\
\text { that include cerebral palsy as } \\
\text { a component ("Neurodevelop- } \\
\text { mental disability at } 2 \text { years of } \\
\text { age in surviving children avail- } \\
\text { able for follow-up" ( } 3 \text { RCTs, } 532 \\
\text { children); "Death or any disabil- } \\
\text { ity by } 2 \text { years of age in children } \\
\text { with known outcome at any } \\
\text { point in time" ( } 7 \text { RCTs, } 1334 \text { chil- } \\
\text { dren); reported as primary out- } \\
\text { comes) }\end{array}$ \\
\hline $\begin{array}{l}\text { Smit } 2013 \\
\text { Postnatal } \\
\text { phenobar- } \\
\text { bital for } \\
\text { the preven- } \\
\text { tion of in- } \\
\text { traventric- } \\
\text { ular haem- } \\
\text { orrhage in } \\
\text { preterm in- } \\
\text { fants }\end{array}$ & $\begin{array}{l}\text { Search: } 31 \\
\text { October } \\
2012 \\
\text { Up-to-date: } \\
17 \text { Decem- } \\
\text { ber } 2012\end{array}$ & $\begin{array}{l}12 \text { RCTs } \\
\text { (Countries: } \\
\text { not reported; } \\
\text { Published: } \\
\text { 1980s: } 8 \\
\text { RCTs; } 1990 \mathrm{~s}: \\
1 \text { RCT: } 2000 \mathrm{~s}: \\
\text { 3 RCTs) }\end{array}$ & 982 infants & $\begin{array}{l}\text { Newborn infants } \\
\text { (less than } 24 \text { hours } \\
\text { old) with gestation- } \\
\text { al age }<34 \text { weeks or } \\
\text { birthweight }<1500 \mathrm{~g} \text {. } \\
\text { We included preterm } \\
\text { infants with gesta- } \\
\text { tional age } 33 \text { to } 36 \\
\text { weeks or birthweight } \\
\text { up to } 1750 \mathrm{~g} \text {, if they } \\
\text { were mechanically } \\
\text { ventilated. We ex- } \\
\text { cluded infants with } \\
\text { serious congenital } \\
\text { malformations }\end{array}$ & $\begin{array}{l}\text { Phenobar- } \\
\text { bital vs } \\
\text { control (12 } \\
\text { RCTs, } 982 \\
\text { neonates) }\end{array}$ & $\begin{array}{l}\text { Other composite outcomes } \\
\text { that include cerebral palsy as } \\
\text { a component ("Mild neurode- } \\
\text { velopmental impairment" ( } 1 \\
\text { RCT, } 101 \text { children); "Severe } \\
\text { neurodevelopmental impair- } \\
\text { ment" ( } 1 \text { RCT, } 101 \text { children); re- } \\
\text { ported as secondary outcomes) }\end{array}$ \\
\hline
\end{tabular}

Neonatal care: hypotension 
Table 2. Characteristics of included reviews (Continued)

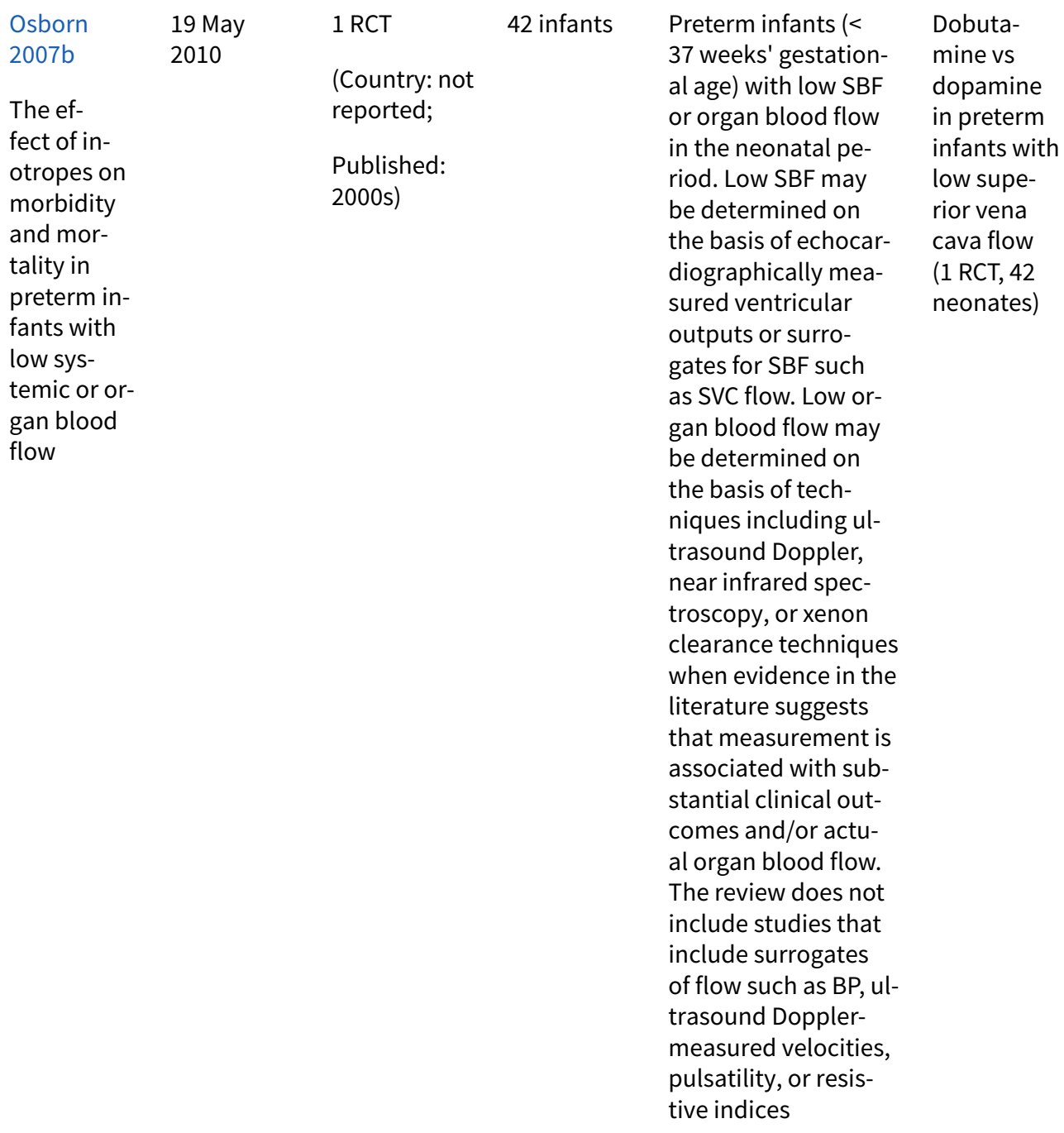

Cerebral palsy ("Cerebral palsy at 3 years in survivors assessed" (1 RCT, 13 children); reported as a primary outcome)

\section{Other composite outcomes} that include cerebral palsy as a component ("Disability at 3 years in survivors assessed" (1 RCT, 13 children); "Death or disability at 3 years" (1 RCT, 37 children); "Death or disability at latest follow-up" (1 RCT, 41 children); reported as primary outcomes)

\section{Neonatal care: fluid therapy}

\begin{tabular}{|c|c|c|c|c|c|c|}
\hline $\begin{array}{l}\text { Osborn } \\
2004 \\
\text { Early vol- } \\
\text { ume ex- } \\
\text { pansion } \\
\text { for preven- } \\
\text { tion of mor- } \\
\text { bidity and } \\
\text { mortali- } \\
\text { ty in very } \\
\text { preterm in- } \\
\text { fants }\end{array}$ & $\begin{array}{l}30 \text { July } \\
2008\end{array}$ & $\begin{array}{l}8 \text { RCTs } \\
\text { (Countries: } \\
\text { not reported; } \\
\text { Published: } \\
\text { 1970s: } 1 \\
\text { RCT; 1980s: } 1 \\
\text { RCT; 1990s: } 4 \\
\text { RCTs; 2000s: } \\
\text { 2 RCTs) }\end{array}$ & $\begin{array}{l}1185 \text { in- } \\
\text { fants }\end{array}$ & $\begin{array}{l}\text { Very preterm infants } \\
\text { born } \leqq 32 \text { weeks' } \\
\text { gestation or } \leqq 1500 \\
\text { g and enrolled and } \\
\text { treated the first } 72 \\
\text { hours after birth. Tri- } \\
\text { als were eligible if } \\
\text { they enrolled uns- } \\
\text { elected preterm in- } \\
\text { fants, preterm in- } \\
\text { fants with clinically } \\
\text { suspected poor per- } \\
\text { fusion (e.g. low BP, } \\
\text { poor cutaneous per- } \\
\text { fusion, metabolic } \\
\text { acidosis), or preterm } \\
\text { infants with low } \\
\text { blood flow (e.g. de- } \\
\text { termined by Doppler } \\
\text { ultrasound). Low BP } \\
\text { may be defined as BP }\end{array}$ & $\begin{array}{l}\text { Volume vs } \\
\text { no treat- } \\
\text { ment } \\
\text { in very } \\
\text { preterm } \\
\text { infants (5 } \\
\text { RCTs, } 978 \\
\text { neonates) } \\
\text { Gelatin vs } \\
\text { fresh frozen } \\
\text { plasma in } \\
\text { hypoten- } \\
\text { sive infants } \\
\text { (1 RCT, 519 } \\
\text { neonates) }\end{array}$ & $\begin{array}{l}\text { Cerebral palsy ("Cerebral pal- } \\
\text { sy in survivors" (1 RCT, } 604 \text { chil- } \\
\text { dren; and } 1 \text { RCT, } 399 \text { children); } \\
\text { reported as a primary outcome) } \\
\text { Other composite outcomes } \\
\text { that include cerebral palsy } \\
\text { as a component ("Severe neu- } \\
\text { rodevelopmental disability in } \\
\text { survivors" (1 RCT, } 604 \text { children; } \\
\text { and } 1 \text { RCT, } 399 \text { children); "Death } \\
\text { or severe neurodevelopmental } \\
\text { disability" (1 RCT, } 776 \text { children; } \\
\text { and } 1 \text { RCT, } 518 \text { children); report- } \\
\text { ed as primary outcomes) }\end{array}$ \\
\hline
\end{tabular}


Table 2. Characteristics of included reviews (Continued)

less than a specified percentile of a standard chart, mean BP $\leqq 30 \mathrm{mmHg}$ in any preterm infant, or mean $\mathrm{BP} \leqq 1 \mathrm{mmHg}$ per week of gesta-

tion

\begin{tabular}{|c|c|c|c|c|c|c|}
\hline \multicolumn{7}{|c|}{ Neonatal care: patent ductus arteriosus } \\
\hline $\begin{array}{l}\text { Fowlie } 2010 \\
\text { Prophylac- } \\
\text { tic intra- } \\
\text { venous in- } \\
\text { domethacin } \\
\text { for prevent- } \\
\text { ing mor- } \\
\text { tality and } \\
\text { morbidity } \\
\text { in preterm } \\
\text { infants }\end{array}$ & $\begin{array}{l}\text { Searches: } \\
\text { April } 2010 \\
\\
\text { Up-to-date: } \\
19 \text { May } \\
2010\end{array}$ & $\begin{array}{l}19 \text { RCTs } \\
\text { (Countries: } \\
\text { North Amer- } \\
\text { ica: 13 RCTs; } \\
\text { Latin Ameri- } \\
\text { ca, Europe, } \\
\text { Asia: 6 RCTs; } \\
\text { Published: } \\
\text { 1980s: 11 } \\
\text { RCTs; 1990s: } \\
7 \text { RCTs; } \\
\text { 2000s; } 1 \text { RCT) }\end{array}$ & $\begin{array}{l}2872 \text { in- } \\
\text { fants }\end{array}$ & $\begin{array}{l}\text { Preterm neonates } \\
\text { (less than } 37 \text { weeks' } \\
\text { completed gesta- } \\
\text { tion) }\end{array}$ & $\begin{array}{l}\text { Prophy- } \\
\text { lactic IV in- } \\
\text { domethacin } \\
\text { vs place- } \\
\text { bo or no } \\
\text { drug (19 } \\
\text { RCTs, } 2872 \\
\text { neonates) }\end{array}$ & $\begin{array}{l}\text { Cerebral palsy ("Neurological } \\
\text { assessments (18-54 months: } \\
\text { Cerebral palsy" ( } 4 \text { RCTs, } 1372 \\
\text { children); "School age neurolog- } \\
\text { ical assessments: Cerebral pal- } \\
\text { sy aged } 8 \text { years" ( } 1 \text { RCT, } 304 \text { chil- } \\
\text { dren); reported as primary out- } \\
\text { comes) } \\
\text { Other composite outcome } \\
\text { that includes cerebral palsy as } \\
\text { a component ("Death or severe } \\
\text { neurosensory impairment" ( } 3 \\
\text { RCTs, } 1491 \text { children); reported } \\
\text { as a primary outcome) }\end{array}$ \\
\hline $\begin{array}{l}\text { Ohlsson } \\
2015 \\
\text { Ibupro- } \\
\text { fen for the } \\
\text { treatment } \\
\text { of patent } \\
\text { ductus ar- } \\
\text { teriosus in } \\
\text { preterm or } \\
\text { low birth } \\
\text { weight (or } \\
\text { both) in- } \\
\text { fants }\end{array}$ & 7 May 2014 & $\begin{array}{l}33 \text { RCTs } \\
\text { (Countries: } \\
\text { Albania: } 1 \\
\text { RCT; Bel- } \\
\text { gium: } 2 \text { RCTs; } \\
\text { Czech Re- } \\
\text { public: } 1 \\
\text { RCT; China: } \\
\text { 1 RCT; Egypt: } \\
\text { 1 RCT; India: } \\
\text { 1 RCT; Iran: } \\
\text { 3 RCTs; Is- } \\
\text { rael: } 1 \text { RCT; } \\
\text { Italy: } 6 \text { RCTs; } \\
\text { Poland: } 1 \\
\text { RCT; Qatar: } 1 \\
\text { RCT; Spain: } \\
\text { 2 RCTs; } \\
\text { Taiwan: } 2 \\
\text { RCTs; Thai- } \\
\text { land: } 2 \text { RCTs; } \\
\text { Tunisia: } 1 \\
\text { RCT; Turkey: } \\
\text { 3 RCTs; UK: } 2 \\
\text { RCTs; USA: } 2 \\
\text { RCTs; } \\
\text { Published: } \\
\text { 1990s: } 4 \\
\text { RCTs; 2000s: } \\
\text { 18 RCTs; }\end{array}$ & $\begin{array}{l}2190 \text { in- } \\
\text { fants }\end{array}$ & $\begin{array}{l}\text { Preterm infants } \\
\text { less than } 37 \text { weeks' } \\
\text { gestational age or } \\
\text { LBW infants (less } \\
\text { than } 2500 \text { g) with } \\
\text { PDA diagnosed ei- } \\
\text { ther clinically or by } \\
\text { echocardiographical- } \\
\text { ly (ECHO) guided cri- } \\
\text { teria in the neonatal } \\
\text { period (less than } 28 \\
\text { days) }\end{array}$ & $\begin{array}{l}\text { Oral } \\
\text { ibupro- } \\
\text { fen vs IV } \\
\text { ibupro- } \\
\text { fen (data } \\
\text { for maxi- } \\
\text { mum of } 4 \\
\text { RCTs, } 304 \\
\text { neonates) }\end{array}$ & $\begin{array}{l}\text { Cerebral palsy ("Moderate/se- } \\
\text { vere cerebral palsy at 18-24 } \\
\text { months" ( } 1 \text { RCT, } 57 \text { children); re- } \\
\text { ported as a secondary outcome) }\end{array}$ \\
\hline
\end{tabular}


Table 2. Characteristics of included reviews (Continued)

2010s: 11

RCTs)

\section{Neonatal care: blood disorders}

\begin{tabular}{|c|c|c|c|c|c|c|}
\hline $\begin{array}{l}\text { Ohlsson } \\
2014 \\
\text { Early ery- } \\
\text { thropoi- } \\
\text { etin for pre- } \\
\text { venting red } \\
\text { blood cell } \\
\text { transfusion } \\
\text { in preterm } \\
\text { and/or } \\
\text { low birth } \\
\text { weight in- } \\
\text { fants }\end{array}$ & 1 July 2013 & $\begin{array}{l}27 \text { RCTs } \\
\text { (Coun- } \\
\text { tries: Aus- } \\
\text { tria: } 2 \text { RCTs; } \\
\text { Bangladesh: } \\
\text { 1 RCT; Chile: } \\
\text { 1 RCT; Chi- } \\
\text { na: } 2 \text { RCTs; } \\
\text { Greece: } 3 \\
\text { RCTs; Iran: } \\
\text { 1 RCT; Italy: } \\
\text { 2 RCTs; } \\
\text { Mexico: } 1 \\
\text { RCT; New } \\
\text { Zealand: } 1 \\
\text { RCT; Poland: } \\
\text { 1 RCT; Sin- } \\
\text { gapore: } 1 \\
\text { RCT; South } \\
\text { Africa: } 1 \text { RCT; } \\
\text { Switzer- } \\
\text { land: } 1 \text { RCT; } \\
\text { Turkey: } 1 \\
\text { RCT; USA: } \\
\text { 5 RCTs; Eu- } \\
\text { rope: } 3 \text { RCTs; } \\
\text { Published } \\
\text { 1990s: } 12 \\
\text { RCTs; } 2000 \text { s: } \\
\text { 13 RCTs; } \\
\text { 2010s: } 2 \\
\text { RCTs) }\end{array}$ & $\begin{array}{l}2209 \text { in- } \\
\text { fants }\end{array}$ & $\begin{array}{l}\text { Preterm }(<37 \text { weeks) } \\
\text { and/or LBW }(<2500 \\
\text { g) neonates less than } \\
8 \text { days of age }\end{array}$ & $\begin{array}{l}\text { Erythro- } \\
\text { poietin vs } \\
\text { placebo or } \\
\text { no treat- } \\
\text { ment ( } 27 \\
\text { RCTs, } 2209 \\
\text { neonates) } \\
\text { Darbepo- } \\
\text { etin alfa } \\
\text { vs place- } \\
\text { bo or no } \\
\text { treatment } \\
\text { (1 RCT, } 66 \\
\text { neonates) }\end{array}$ & $\begin{array}{l}\text { Cerebral palsy ("Cerebral palsy } \\
\text { at } 18 \text { - } 22 \text { months' corrected age } \\
\text { (in children examined)" ( } 2 \text { RCTs, } \\
153 \text { children; and } 1 \text { RCT, } 51 \text { chil- } \\
\text { dren); reported as secondary } \\
\text { outcomes) } \\
\text { Other composite outcome } \\
\text { that includes cerebral pal- } \\
\text { sy as a component ("Any neu- } \\
\text { rodevelopmental impairment } \\
\text { at } 18-22 \text { months' corrected age } \\
\text { (in children examined)" (1 RCT< } \\
99 \text { children); reported as a sec- } \\
\text { ondary outcome) } \\
\text { Motor dysfunction ("PDI < } 70 \\
\text { at } 18 \text { - } 22 \text { months' corrected age } \\
\text { (in children examined)" (1 RCT, } \\
90 \text { children); reported as a sec- } \\
\text { ondary outcome) }\end{array}$ \\
\hline $\begin{array}{l}\text { Whyte } 2011 \\
\text { Low ver- } \\
\text { sus high } \\
\text { haemoglo- } \\
\text { bin con- } \\
\text { centration } \\
\text { threshold } \\
\text { for blood } \\
\text { transfusion } \\
\text { for prevent- } \\
\text { ing mor- } \\
\text { bidity and } \\
\text { mortali- } \\
\text { ty in very } \\
\text { low birth } \\
\text { weight in- } \\
\text { fants }\end{array}$ & $\begin{array}{l}\text { Search: Au- } \\
\text { gust } 2011 \\
\text { Up-to-date: } \\
1 \text { Septem- } \\
\text { ber } 2011\end{array}$ & $\begin{array}{l}\text { 5 RCTs } \\
\text { (Countries: } \\
\text { Canada: } 1 \\
\text { RCT; Interna- } \\
\text { tional (Cana- } \\
\text { da, USA, Aus- } \\
\text { tralia): } 1 \text { RCT; } \\
\text { Taiwan: } 1 \\
\text { RCT; USA: } 2 \\
\text { RCTs; } \\
\text { Published: } \\
\text { 1980s: } 1 \\
\text { RCT; 1990s: } 1 \\
\text { RCT; 2000s: } 3 \\
\text { RCTs) }\end{array}$ & 670 infants & $\begin{array}{l}\text { VLBW infants (i.e. } \\
\text { of birthweight less } \\
\text { than or equal to } 1500 \\
\text { g, or less than } 32 \\
\text { weeks' gestation- } \\
\text { al age) admitted to } \\
\text { NICU at less than } \\
1 \text { week of age. We } \\
\text { aimed specifically } \\
\text { to include studies of } \\
\text { infants receiving all } \\
\text { levels of intensive } \\
\text { care }\end{array}$ & $\begin{array}{l}\text { Transfu- } \\
\text { sion at a } \\
\text { low haemo- } \\
\text { globin or } \\
\text { haemat- } \\
\text { ocrit lev- } \\
\text { el (restric- } \\
\text { tive) vs } \\
\text { transfusion } \\
\text { at a high } \\
\text { haemo- } \\
\text { globin or } \\
\text { haemat- } \\
\text { ocrit level } \\
\text { (liberal) (4 } \\
\text { RCTs, } 614 \\
\text { neonates) }\end{array}$ & $\begin{array}{l}\text { Cerebral palsy ("Neurosenso- } \\
\text { ry impairment at } 18-21 \text { months' } \\
\text { follow-up among survivors: } \\
\text { Cerebral palsy" ( } 1 \text { RCT, } 335 \text { chil- } \\
\text { dren); reported as a secondary } \\
\text { outcome) } \\
\text { Other composite outcomes } \\
\text { that include cerebral palsy as } \\
\text { a component ("Death or severe } \\
\text { morbidity: at } 18-21 \text { months' fol- } \\
\text { low-up with MDI < } 70 " \text { ( } 1 \text { RCT, } \\
421 \text { children); "Death or severe } \\
\text { morbidity: at } 18-21 \text { months' fol- } \\
\text { low-up with MDI < } 85 " \text { ( } 1 \text { RCT, } \\
421 \text { children); reported as pri- } \\
\text { mary outcomes) ("Neurosenso- } \\
\text { ry impairment at } 18-21 \text { months' } \\
\text { follow-up among survivors: any } \\
\text { neurosensory impairment" (1 }\end{array}$ \\
\hline
\end{tabular}


Table 2. Characteristics of included reviews (Continued)

RCT, 328 children); reported as a secondary outcome)

Neonatal care: pulmonary hypertension

\begin{tabular}{|c|c|c|c|c|c|c|}
\hline $\begin{array}{l}\text { More } 2016 \\
\text { Endothe- } \\
\text { lin recep- } \\
\text { tor antag- } \\
\text { onists for } \\
\text { persistent } \\
\text { pulmonary } \\
\text { hyperten- } \\
\text { sion in term } \\
\text { and late } \\
\text { preterm in- } \\
\text { fants }\end{array}$ & $\begin{array}{l}28 \text { Decem- } \\
\text { ber } 2015\end{array}$ & $\begin{array}{l}2 \text { RCTs } \\
\text { (Countries: } \\
\text { Saudi Arabia: } \\
\text { 1 RCT; un- } \\
\text { clear (mul- } \\
\text { ti-centre): } 1 \\
\text { RCT; } \\
\text { Published: } \\
\text { 2010s: } 2 \\
\text { RCTs) }\end{array}$ & 68 infants & $\begin{array}{l}\text { Late preterm in- } \\
\text { fants (born at } 34+0 \\
\text { to } 36+6 \text { weeks), term } \\
\text { infants (born at } 37+0 \\
\text { to } 41+6 \text { weeks), and } \\
\text { post-term infants } \\
\text { (i.e. born after } 41+6 \\
\text { weeks' gestation) } \\
\text { until post-menstru- } \\
\text { al age (PMA) up to } \\
44 \text { weeks with PPHN } \\
\text { were eligible for in- } \\
\text { clusion. The diag- } \\
\text { nosis of PPHN was } \\
\text { clinical or was based } \\
\text { on echocardiogra- } \\
\text { phy. Clinical diagno- } \\
\text { sis of PPHN was con- } \\
\text { sidered when there } \\
\text { was hypoxaemia re- } \\
\text { fractory to oxygen } \\
\text { therapy and me- } \\
\text { chanical ventilation } \\
\text { (Roberts } 1997 \text { ). The } \\
\text { echocardiographic } \\
\text { diagnosis of PPHN } \\
\text { was made by demon- } \\
\text { strating the presence } \\
\text { of extrapulmonary } \\
\text { right-to-left shunt- } \\
\text { ing at the ductal or } \\
\text { atrial level, near or } \\
\text { suprasystemic pul- } \\
\text { monary arterial pres- } \\
\text { sures, and doppler } \\
\text { evidence of tricus- } \\
\text { pid regurgitation } \\
\text { (Dhillon } 2012 ; \text { Stayer } \\
2010 \text { ) }\end{array}$ & $\begin{array}{l}\text { Endothe- } \\
\text { lin receptor } \\
\text { antagonists } \\
\text { vs placebo } \\
\text { (1 RCT, } 47 \\
\text { neonates) }\end{array}$ & $\begin{array}{l}\text { Cerebral palsy ("Cerebral pal- } \\
\text { sy" ( } 1 \text { RCT, } 37 \text { children); report- } \\
\text { ed as a secondary outcome) } \\
\text { Motor dysfunction ("Adverse } \\
\text { neurodevelopmental outcome } \\
\text { at } 6 \text { months" (1 RCT, } 37 \text { chil- } \\
\text { dren); reported as a secondary } \\
\text { outcome) }\end{array}$ \\
\hline
\end{tabular}

\section{Neonatal care: resuscitation}

\begin{tabular}{|c|c|c|c|c|c|c|}
\hline $\begin{array}{l}\text { Tan } 2005 \\
\text { Air versus } \\
\text { oxygen for } \\
\text { resuscita- } \\
\text { tion of in- } \\
\text { fants at } \\
\text { birth }\end{array}$ & $\begin{array}{l}\text { Search: De- } \\
\text { cember } \\
2003 / \text { Janu- } \\
\text { ary } 2004 \\
\text { Up-to-date: } \\
15 \text { February } \\
2005\end{array}$ & $\begin{array}{l}5 \text { RCTs } \\
\text { (Countries: } \\
\text { India: } 1 \text { RCT; } \\
6 \text { countries: } \\
1 \text { RCT; not } \\
\text { reported: } 3 \\
\text { RCTs } \\
\text { Published: } \\
\text { 1990s: } 2 \\
\text { RCTs; } 2000 \text { s: } \\
3 \text { RCTs) }\end{array}$ & $\begin{array}{l}1302 \text { in- } \\
\text { fants }\end{array}$ & $\begin{array}{l}\text { Term or preterm } \\
\text { neonates requiring } \\
\text { IPPV at birth }\end{array}$ & $\begin{array}{l}\text { Room air } \\
\text { vs } 100 \% \\
\text { oxygen ( } 5 \\
\text { RCTs, } 1302 \\
\text { neonates) }\end{array}$ & $\begin{array}{l}\text { Cerebral palsy ("Long-term } \\
\text { neurodevelopmental outcome: } \\
\text { cerebral palsy in those followed } \\
\text { up at } 18-24 \text { months" ( } 1 \text { RCT, } 213 \\
\text { children); reported as a post hoc } \\
\text { outcome) } \\
\text { Motor dysfunction ("Long-term } \\
\text { neurodevelopmental outcome: } \\
\text { not walking in those followed } \\
\text { up at } 18-24 \text { months" (1 RCT, } 213 \\
\text { children); reported as a post hoc } \\
\text { outcome) }\end{array}$ \\
\hline
\end{tabular}


Table 2. Characteristics of included reviews (Continued)

\section{Neonatal care: nitric oxide}

\begin{tabular}{|c|c|c|c|c|c|c|}
\hline $\begin{array}{l}\text { Barrington } \\
2010 \\
\text { Inhaled ni- } \\
\text { tric oxide } \\
\text { for respira- } \\
\text { tory failure } \\
\text { in preterm } \\
\text { infants }\end{array}$ & $\begin{array}{l}\text { Search: } \\
\text { June } 2010 \\
\text { Up-to-date: } \\
12 \text { October } \\
2010\end{array}$ & $\begin{array}{l}\text { 14 RCTs } \\
\text { (Countries: } \\
\text { Europe: } 3 \\
\text { RCTs; Tai- } \\
\text { wan: } 1 \text { RCT; } \\
\text { USA: } 1 \text { RCT; } \\
\text { not report- } \\
\text { ed/unclear: } 9 \\
\text { RCTs } \\
\text { Published: } \\
\text { 1990s: } 3 \\
\text { RCTs; 2000s: } \\
11 \text { RCTs) }\end{array}$ & $\begin{array}{l}3430 \text { in- } \\
\text { fants }\end{array}$ & $\begin{array}{l}\text { Premature infants } \\
\text { (less than } 35 \text { weeks' } \\
\text { gestation) with res- } \\
\text { piratory failure after } \\
\text { adequate treatment } \\
\text { with surfactant }\end{array}$ & $\begin{array}{l}\text { Inhaled } \\
\text { NO com- } \\
\text { pared with } \\
\text { control; } \\
\text { analyses } \\
\text { conducted } \\
\text { based on: } \\
\text { 1. Studies } \\
\text { with en- } \\
\text { try be- } \\
\text { fore } 3 \\
\text { days } \\
\text { based } \\
\text { on oxy- } \\
\text { gena- } \\
\text { tion (9 } \\
\text { RCTs, } \\
1006 \\
\text { neonates) } \\
\text { 2. Studies } \\
\text { with en- } \\
\text { try after } \\
3 \text { days } \\
\text { based } \\
\text { on BPD } \\
\text { risk (2 } \\
\text { RCTs, } \\
624 \\
\text { neonates) } \\
\text { 3. Studies } \\
\text { of rou- } \\
\text { tine use } \\
\text { in intu- } \\
\text { bated } \\
\text { preterm } \\
\text { infants } \\
\text { (3 RCTs, } \\
1800 \\
\text { neonates) }\end{array}$ & $\begin{array}{l}\text { Cerebral palsy ("Cerebral pal- } \\
\text { sy"; reported as an outcome (2 } \\
\text { RCTs, } 209 \text { children; } 2 \text { RCTs, } 498 \\
\text { children; and } 2 \text { RCTs, } 593 \text { chil- } \\
\text { dren) (not separated into prima- } \\
\text { ry/secondary)) } \\
\text { Other composite outcome } \\
\text { that includes cerebral palsy as } \\
\text { a component ("Neurodevelop- } \\
\text { mental disability" ( } 2 \text { RCTs, } 208 \\
\text { children; } 2 \text { RCTs, } 498 \text { children; } \\
\text { and } 2 \text { RCTs, } 593 \text { children); re- } \\
\text { ported as an outcome (not sep- } \\
\text { arated into primary/secondary)) } \\
\text { Motor dysfunction ("Bayley } \\
\text { MDI or PDI <-2SD" (1 RCT, } 138 \\
\text { children); reported as an out- } \\
\text { come (not separated into pri- } \\
\text { mary/secondary)) }\end{array}$ \\
\hline
\end{tabular}

\begin{tabular}{llll}
\hline Finer 2006 & $\begin{array}{l}\text { Search: No- } \\
\text { vember }\end{array}$ & 14 RCTs & $\begin{array}{l}1715 \text { in- } \\
\text { fants }\end{array}$ \\
$\begin{array}{l}\text { Nitric oxide } \\
\text { for respira- }\end{array}$ & 2005 & $\begin{array}{l}\text { (Countries: } \\
\text { 33 French } \\
\text { and Belgian }\end{array}$ \\
in infailure & Up-to-date: & 30 May & $\begin{array}{l}\text { Units: } 1 \text { RCT; } \\
\text { not reported: }\end{array}$ \\
born at or & 2006 & 13 RCTs \\
near term & & Published: \\
& & 1990s: 11 \\
& & RCTs; 2000 s: \\
& & 3 RCTs)
\end{tabular}

Newborn infants (<
1 month of age) with
hypoxaemia suspect-
ed to be due to lung
disease, pulmonary
hypertension with
right-to-left shunting,
or both
Only studies in term
and near-term in-
fants (> 34 weeks'
gestation) were in-
cluded

Efforts were made in all studies to exclude

\section{Inhaled NO}

vs control

(10 RCTs,

1068 in-

fants)

Inhaled NO

vs control

in infants

with di-

aphragmat-

ic hernia

(2 RCTs, 84

neonates)
Cerebral palsy ("Cerebral palsy among survivors" (2 RCTs, 299 children; and 1 RCT, 22 children); reported as an outcome (not separated into primary/secondary))

\section{Other composite outcome} that includes cerebral palsy as a component ("Neurodevelopmental disability at 18 to 24 months among survivors" (2 RCTs, 301 children); reported as an outcome (not separated into primary/secondary)) 
Table 2. Characteristics of included reviews (Continued)

infants with intracardiac shunting due to structural congenital heart disease

Infants with diaphragmatic hernia may respond differently from other near term infants (from preliminary data), and as far as possible results from infants with diaphragmatic hernias have been evaluated separately
Motor dysfunction ("Bayley PDI more than 2 SD below the mean" (2 RCTs, 283 children); reported as an outcome (not separated into primary/secondary))

Neonatal care: apnoea

\begin{tabular}{|c|c|c|c|c|c|c|}
\hline $\begin{array}{l}\text { Hender- } \\
\text { son-Smart } \\
\text { 2010b } \\
\text { Methylxan- } \\
\text { thine treat- } \\
\text { ment for } \\
\text { apnoea in } \\
\text { preterm in- } \\
\text { fants }\end{array}$ & $\begin{array}{l}\text { Search: } \\
\text { June } 2010 \\
\text { Up-to-date: } \\
4 \text { July } 2010\end{array}$ & $\begin{array}{l}6 \text { RCTs } \\
\text { (Countries: } \\
\text { not reported } \\
\text { Published: } \\
\text { 1980s: } 3 \\
\text { RCTs; } 1990 \text { s: } \\
\text { 1 RCT; 2000s: } \\
\text { 2 RCTs) }\end{array}$ & 959 infants & $\begin{array}{l}\text { Preterm infants with } \\
\text { recurrent apnoea. } \\
\text { There must have } \\
\text { been an effort to ex- } \\
\text { clude specific sec- } \\
\text { ondary causes of ap- } \\
\text { noea }\end{array}$ & $\begin{array}{l}\text { Any } \\
\text { methylx- } \\
\text { anthine vs } \\
\text { control } \\
\text { (placebo } \\
\text { or no drug } \\
\text { therapy) (6 } \\
\text { RCTs, 959 } \\
\text { neonates) }\end{array}$ & $\begin{array}{l}\text { Cerebral palsy ("Cerebral pal- } \\
\text { sy" ( } 1 \text { RCT, } 729 \text { children); report- } \\
\text { ed as a secondary outcome) } \\
\text { Other composite outcome } \\
\text { that includes cerebral palsy } \\
\text { as a component ("Death or ma- } \\
\text { jor disability by late infancy" (1 } \\
\text { RCT, } 767 \text { children); reported as a } \\
\text { secondary outcome) }\end{array}$ \\
\hline $\begin{array}{l}\text { Hender- } \\
\text { son-Smart } \\
\text { 2010c } \\
\text { Prophylac- } \\
\text { tic methylx- } \\
\text { anthine for } \\
\text { prevention } \\
\text { of apnoea } \\
\text { in preterm } \\
\text { infants }\end{array}$ & $\begin{array}{l}\text { Search: Au- } \\
\text { gust } 2010 \\
\text { Up-to-date: } \\
29 \text { Septem- } \\
\text { ber } 2010\end{array}$ & $\begin{array}{l}3 \text { RCTs } \\
\text { (Countries: } \\
\text { not reported } \\
\text { Published: } \\
\text { 1980s: } 2 \\
\text { RCTs; 2000s: } \\
1 \text { RCT) }\end{array}$ & 557 infants & $\begin{array}{l}\text { Preterm infants, } \\
\text { particularly those } \\
\text { born at less than } 34 \\
\text { weeks' gestation, } \\
\text { who are at risk of } \\
\text { developing recur- } \\
\text { rent apnoea, brady- } \\
\text { cardia, and hypoxic } \\
\text { episodes }\end{array}$ & $\begin{array}{l}\text { Prophylac- } \\
\text { tic methylx- } \\
\text { anthine vs } \\
\text { control ( } 3 \\
\text { RCTs, } 557 \\
\text { neonates) }\end{array}$ & $\begin{array}{l}\text { Cerebral palsy ("Cerebral pal- } \\
\text { sy" (1 RCT, } 415 \text { children); report- } \\
\text { ed as a secondary outcome) } \\
\text { Other composite outcome } \\
\text { that includes cerebral palsy } \\
\text { as a component ("Death or ma- } \\
\text { jor disability" ( } 1 \text { RCT, } 423 \text { chil- } \\
\text { dren); reported as a secondary } \\
\text { outcome) }\end{array}$ \\
\hline
\end{tabular}

Neonatal care: respiratory distress syndrome

\begin{tabular}{|c|c|c|c|c|c|c|}
\hline $\begin{array}{l}\text { Howlett } \\
2015 \\
\text { Inositol in } \\
\text { preterm in- } \\
\text { fants at risk } \\
\text { for or hav- } \\
\text { ing respi- } \\
\text { ratory dis- } \\
\text { tress syn- } \\
\text { drome }\end{array}$ & $\begin{array}{l}14 \text { Septem- } \\
\text { ber } 2014\end{array}$ & $\begin{array}{l}4 \text { RCTs } \\
\text { (Countries: } \\
\text { Finland: } 2 \\
\text { RCTs; USA: } 2 \\
\text { RCTs } \\
\text { Published: } \\
\text { 1980s: } 1 \\
\text { RCT; 1990s: } 2 \\
\text { RCTs; 2010s: } \\
\text { 1 RCT) }\end{array}$ & 429 infants & $\begin{array}{l}\text { Preterm infants }(< \\
37 \text { weeks' post-men- } \\
\text { strual age) or LBW }(< \\
2500 \mathrm{~g}) \text { infants }\end{array}$ & $\begin{array}{l}\text { Inositol } \\
\text { supple- } \\
\text { mentation } \\
\text { (repeat } \\
\text { doses) vs } \\
\text { control (3 } \\
\text { RCTs, } 355 \\
\text { neonates) }\end{array}$ & $\begin{array}{l}\text { Other composite outcomes } \\
\text { that include cerebral palsy as } \\
\text { a component ("Major neural } \\
\text { developmental impairment at } \\
\text { one year corrected age" ( } 1 \mathrm{RCT} \text {, } \\
169 \text { children); reported as a sec- } \\
\text { ondary outcome) } \\
\text { Motor dysfunction ("Minor } \\
\text { neural developmental impair- } \\
\text { ment at one year corrected } \\
\text { age" (1 RCT, } 169 \text { children); re- } \\
\text { ported as a secondary outcome) }\end{array}$ \\
\hline Seger 2009 & $\begin{array}{l}\text { Search: De- } \\
\text { cember } \\
2008\end{array}$ & 13 RCTs & $\begin{array}{l}1611 \text { in- } \\
\text { fants }\end{array}$ & $\begin{array}{l}\text { Preterm infants (< } \\
37 \text { weeks' gestation) } \\
\text { with clinical and/or }\end{array}$ & $\begin{array}{l}\text { Animal-de- } \\
\text { rived sur- } \\
\text { factant ex- }\end{array}$ & $\begin{array}{l}\text { Cerebral palsy ("Cerebral pal- } \\
\text { sy" ( } 1 \text { RCT, } 73 \text { children); report- } \\
\text { ed as a secondary outcome) }\end{array}$ \\
\hline
\end{tabular}


Table 2. Characteristics of included reviews (Continued)

$\begin{array}{lllll}\begin{array}{l}\text { Animal de- } \\ \text { rived sur- }\end{array} & \begin{array}{l}\text { Up-to-date: } \\ \text { 13 February }\end{array} & \begin{array}{l}\text { (Countries: } \\ \text { not reported }\end{array} & \begin{array}{l}\text { radiological evidence } \\ \text { of respiratory dis- }\end{array} & \begin{array}{l}\text { tract treat- } \\ \text { ment of }\end{array} \\ \begin{array}{l}\text { tress syndrome re- } \\ \text { tract for }\end{array} & 2009 & \begin{array}{l}\text { Published: } \\ \text { quiring assisted ven- }\end{array} & \begin{array}{l}\text { respiratory } \\ \text { distress (all }\end{array} \\ \text { treatment } & \text { 1980s: } 7 & \text { tilation } & \text { infants) (13 } \\ \text { of respira- } & \text { RCTs; } 1990 \mathrm{~s}: & & \text { RCTs, } 1611 \\ \text { tory dis- } & \text { 6RCTs) } & & \text { neonates) }\end{array}$

Other composite outcome that includes cerebral palsy as a component ("Major neurodevelopmental disability in survivors" (1 RCT, 73 children); reported as a secondary outcome)

tress syn-

drome

\begin{tabular}{|c|c|c|c|c|c|c|}
\hline $\begin{array}{l}\text { Soll } 2000 \\
\text { Synthetic } \\
\text { surfactant } \\
\text { for respi- } \\
\text { ratory dis- } \\
\text { tress syn- } \\
\text { drome in } \\
\text { preterm in- } \\
\text { fants }\end{array}$ & $\begin{array}{l}\text { Search: } \\
\text { not report- } \\
\text { ed } \\
\text { Up-to-date: } \\
21 \text { May } \\
1998\end{array}$ & $\begin{array}{l}6 \text { RCTs } \\
\text { (Countries: } \\
\text { not clear- } \\
\text { ly report- } \\
\text { ed; Cana- } \\
\text { da/USA/ } \\
\text { both: } 3 \text { RCTs } \\
\text { Published; } \\
\text { 1980s: } 1 \\
\text { RCT; 1990s: } 5 \\
\text { RCTs) }\end{array}$ & $\begin{array}{l}2358 \text { in- } \\
\text { fants }\end{array}$ & $\begin{array}{l}\text { Neonates with clin- } \\
\text { ical and radiologi- } \\
\text { cal evidence of res- } \\
\text { piratory distress syn- } \\
\text { drome requiring as- } \\
\text { sisted ventilation }\end{array}$ & $\begin{array}{l}\text { Synthet- } \\
\text { ic surfac- } \\
\text { tant vs } \\
\text { control ( } 6 \\
\text { RCTs, } 2358 \\
\text { neonates) }\end{array}$ & $\begin{array}{l}\text { Cerebral palsy ("Cerebral palsy } \\
\text { in survivors examined" ( } 5 \text { RCTs, } \\
1557 \text { children); reported as an } \\
\text { outcome (not separated into } \\
\text { primary/secondary)) } \\
\text { Severity of cerebral palsy } \\
\text { ("Moderate - severe cerebral } \\
\text { palsy in survivors examined" (5 } \\
\text { RCTs, } 1557 \text { children); reported } \\
\text { as an outcome (not separated } \\
\text { into primary/secondary)) }\end{array}$ \\
\hline $\begin{array}{l}\text { Soll } 2010 \\
\text { Prophylac- } \\
\text { tic protein } \\
\text { free syn- } \\
\text { thetic sur- } \\
\text { factant for } \\
\text { prevent- } \\
\text { ing mor- } \\
\text { bidity and } \\
\text { mortality in } \\
\text { preterm in- } \\
\text { fants }\end{array}$ & $\begin{array}{l}\text { Search: } \\
\text { September } \\
2009 \\
\text { Up-to-date: } \\
27 \text { October } \\
2009\end{array}$ & $\begin{array}{l}7 \text { RCTs } \\
\text { (Countries: } \\
\text { 1: UK; } 6 \\
\text { RCTs: not re- } \\
\text { ported } \\
\text { Published: } \\
\text { 1980s: } 3 \\
\text { RCTs; 1990s: } \\
\text { 4 RCTs) }\end{array}$ & $\begin{array}{l}1583 \text { in- } \\
\text { fants }\end{array}$ & $\begin{array}{l}\text { Premature infants } \\
\text { with or without evi- } \\
\text { dence of surfactant } \\
\text { deficiency }\end{array}$ & $\begin{array}{l}\text { Prophy- } \\
\text { lactic syn- } \\
\text { thetic sur- } \\
\text { factant vs } \\
\text { control ( } 7 \\
\text { RCTs, } 1583 \\
\text { neonates) }\end{array}$ & $\begin{array}{l}\text { Cerebral palsy ("Cerebral pal- } \\
\text { sy, } 1-2 \text { years" (4 RCTs, } 670 \text { chil- } \\
\text { dren); reported as a secondary } \\
\text { outcome) } \\
\text { Severity of cerebral palsy } \\
\text { ("Cerebral palsy, moderate/se- } \\
\text { vere" (4 RCTs, } 670 \text { children); re- } \\
\text { ported as a secondary outcome) }\end{array}$ \\
\hline
\end{tabular}

\section{Neonatal care: mechanical ventilation}

\begin{tabular}{|c|c|c|c|c|c|c|}
\hline $\begin{array}{l}\text { Cools } 2015 \\
\text { Elective } \\
\text { high fre- } \\
\text { quency os- } \\
\text { cillatory } \\
\text { ventilation } \\
\text { versus con- } \\
\text { ventional } \\
\text { ventilation } \\
\text { for acute } \\
\text { pulmonary } \\
\text { dysfunction } \\
\text { in preterm } \\
\text { infants }\end{array}$ & $\begin{array}{l}30 \text { Novem- } \\
\text { ber } 2014\end{array}$ & $\begin{array}{l}19 \text { RCTs } \\
\text { (Countries: } \\
\text { not reported } \\
\text { Published: } \\
\text { 1980s: } 1 \\
\text { RCT; } 1990 \mathrm{s:} 6 \\
\text { RCTs; 2000s: } \\
\text { 10 RCTs; } \\
\text { 2010s: } 2 \\
\text { RCTs) }\end{array}$ & $\begin{array}{l}4096 \text { in- } \\
\text { fants }\end{array}$ & $\begin{array}{l}\text { Preterm or LBW in- } \\
\text { fants with pulmonary } \\
\text { dysfunction, main- } \\
\text { ly due to respiratory } \\
\text { distress syndrome, } \\
\text { who were considered } \\
\text { to require IPPV }\end{array}$ & $\begin{array}{l}\text { High-fre- } \\
\text { quency os- } \\
\text { cillatory } \\
\text { ventilation } \\
\text { vs conven- } \\
\text { tional ven- } \\
\text { tilation (19 } \\
\text { RCTs, } 4096 \\
\text { neonates) }\end{array}$ & $\begin{array}{l}\text { Cerebral palsy (reported in } \\
\text { text as a secondary outcome ( } 3 \\
\text { RCTs)) }\end{array}$ \\
\hline $\begin{array}{l}\text { Ho } 2015 \\
\text { Continuous } \\
\text { distend- } \\
\text { ing pres- }\end{array}$ & $\begin{array}{l}30 \text { April } \\
2015\end{array}$ & $\begin{array}{l}6 \text { RCTs } \\
\text { (Countries: } \\
\text { not reported }\end{array}$ & 355 infants & $\begin{array}{l}\text { Preterm infants with } \\
\text { respiratory failure }\end{array}$ & $\begin{array}{l}\text { Continuous } \\
\text { distending } \\
\text { pressure } \\
\text { vs stan- } \\
\text { dard care (6 }\end{array}$ & $\begin{array}{l}\text { Cerebral palsy ("Cerebral pal- } \\
\text { sy" ( } 1 \text { RCT, } 36 \text { children); report- } \\
\text { ed as a secondary outcome) }\end{array}$ \\
\hline
\end{tabular}


Table 2. Characteristics of included reviews (Continued)

sure for res-

piratory

distress in

preterm in-

fants
Published:

1970s: 4

RCTs; 1990s:

1 RCT; 2000s:

$1 \mathrm{RCT}$ )
RCTs, 355

neonates)

Other composite outcomes that include cerebral palsy as a component ("Death or severe disability" (1 RCT, 38 children); "Severe disability" (1 RCT, 37 children); "Any disability" (1 RCT, 37 children); reported as secondary outcomes)

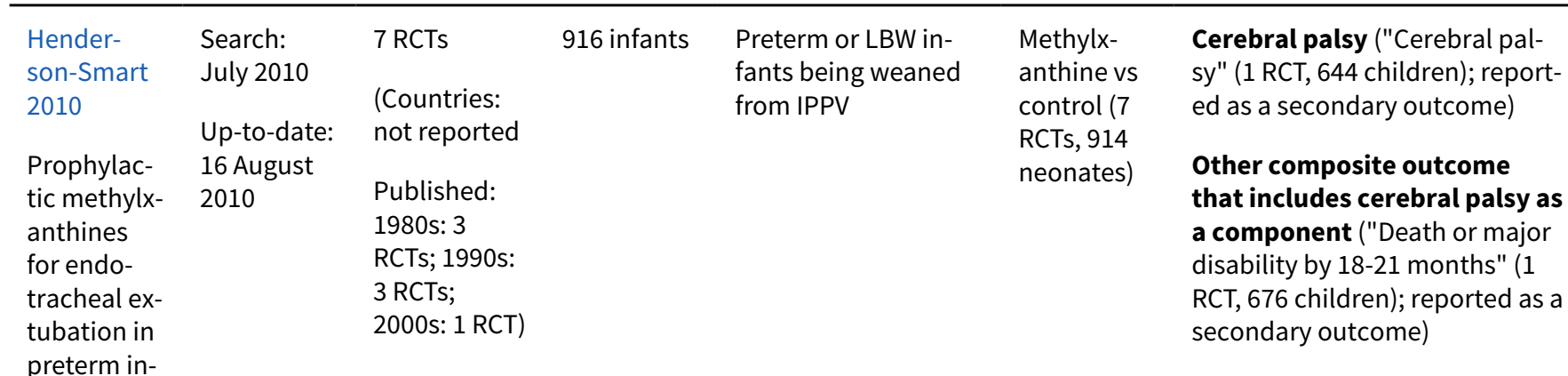

fants

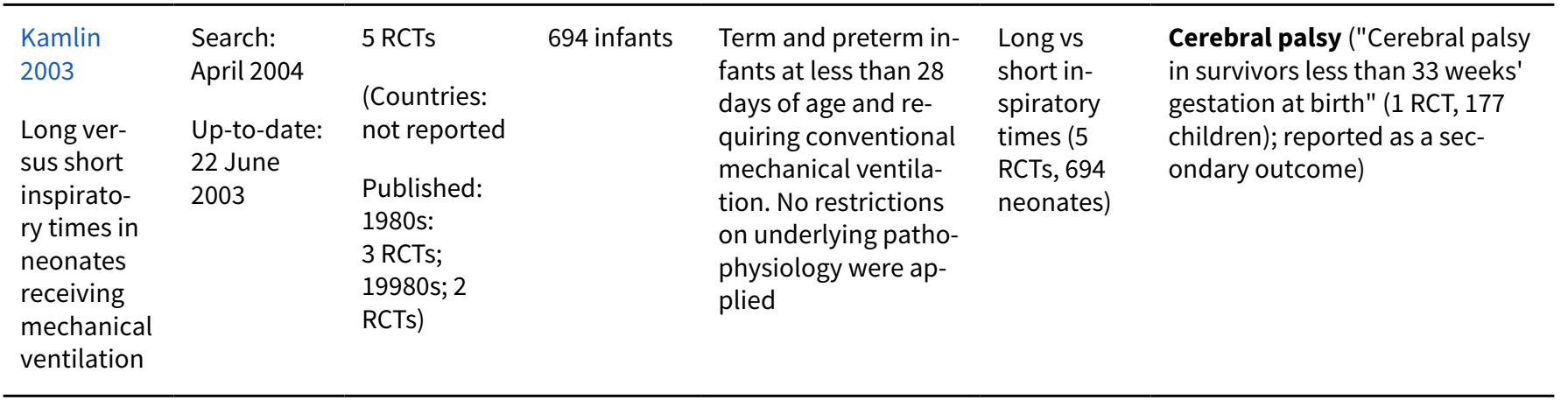

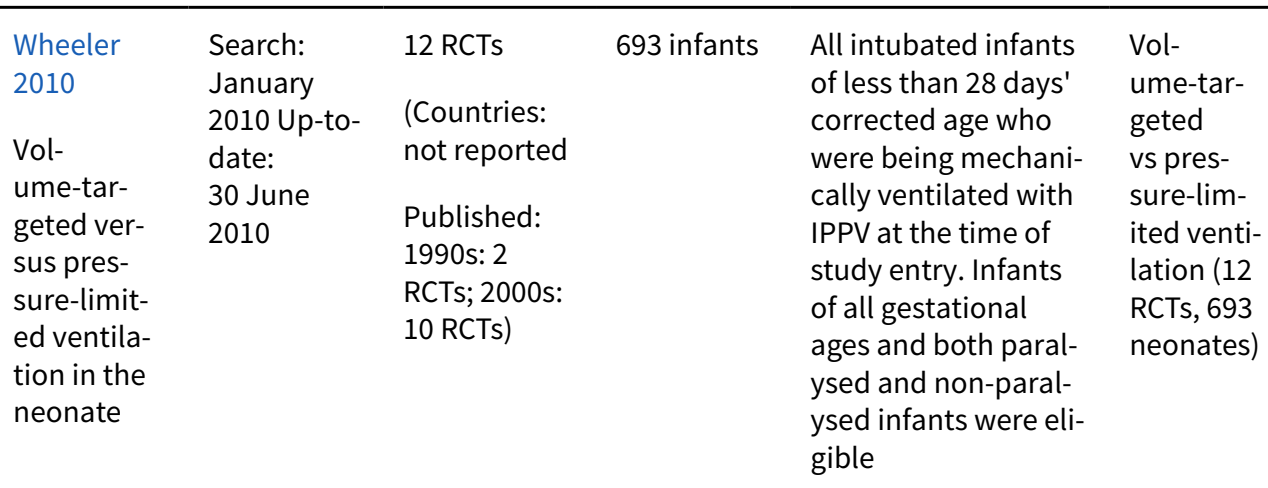

\section{Other composite outcomes that include cerebral palsy as a component ("Severe dis- ability (any definition)" (2 RCTs, 209 children); "Severe disabili- ty (any definition) or death" (1 RCT, 109 children; reported as outcomes from post hoc meta- analyses)}

Motor dysfunction ("Gross motor developmental issue (any definition)" (1 RCT, 128 children); reported as an outcome from a post hoc meta-analysis)

\section{Neonatal care: bronchopulmonary dysplasia}

\begin{tabular}{|c|c|c|c|c|c|c|}
\hline $\begin{array}{l}\text { Doyle } \\
2014 b \\
\text { Early (<8 } \\
\text { days) post- } \\
\text { natal corti- } \\
\text { costeroids } \\
\text { for prevent- } \\
\text { ing chron- }\end{array}$ & $\begin{array}{l}\text { Search: Au- } \\
\text { gust } 2013 \\
\text { Up-to-date: } \\
18 \text { February } \\
2014\end{array}$ & $\begin{array}{l}29 \text { RCTs } \\
\text { (Countries: } \\
\text { not reported } \\
\text { Published: } \\
\text { 1970s: } 1 \text { RCT; } \\
\text { 1990s: } 17 \\
\text { RCTs; } 2000 \text { s: }\end{array}$ & $\begin{array}{l}3750 \text { in- } \\
\text { fants }\end{array}$ & $\begin{array}{l}\text { Preterm infants at } \\
\text { risk of developing } \\
\text { chronic lung disease, } \\
\text { including those who } \\
\text { were ventilator de- } \\
\text { pendent }\end{array}$ & $\begin{array}{l}\text { Early }(< \\
8 \text { days) } \\
\text { postnatal } \\
\text { corticos- } \\
\text { teroids vs } \\
\text { control ( } 29 \\
\text { RCTs, } 3750 \\
\text { neonates) }\end{array}$ & $\begin{array}{l}\text { Cerebral palsy ("Cerebral pal- } \\
\text { sy" ( } 12 \text { RCTs, } 1452 \text { children); } \\
\text { "Cerebral palsy in survivors as- } \\
\text { sessed" ( } 12 \text { RCTs, } 959 \text { children); } \\
\text { reported as primary outcomes) } \\
\text { Cerebral palsy or death } \\
\text { ("Death or cerebral palsy" ( } 12\end{array}$ \\
\hline
\end{tabular}


Table 2. Characteristics of included reviews (Continued)

$\begin{array}{ll}\text { ic lung dis- } & 10 \text { RCTs; } \\ \text { ease in } & 2010 \text { : } 1 \text { RCT }\end{array}$

preterm infants
RCTs, 1452 children); reported as a primary outcome)

Other composite outcomes that include cerebral palsy as a component ("Major neurosensory disability (variable criteria - see individual studies)" (7 RCTs, 1233 children); "Major neurosensory disability (variable criteria) in survivors examined" (7 RCTs, 799 children); "Death or major neurosensory disability (variable criteria)" (7 RCTs, 1233 children); reported as primary outcomes)

Motor dysfunction ("Bayley Psychomotor Developmental Index (PDI) <-2SD" (3 RCTs, 842 children); "Bayley PDI <-2SD in tested survivors" (3 RCTs, 528 children); reported as primary outcomes)

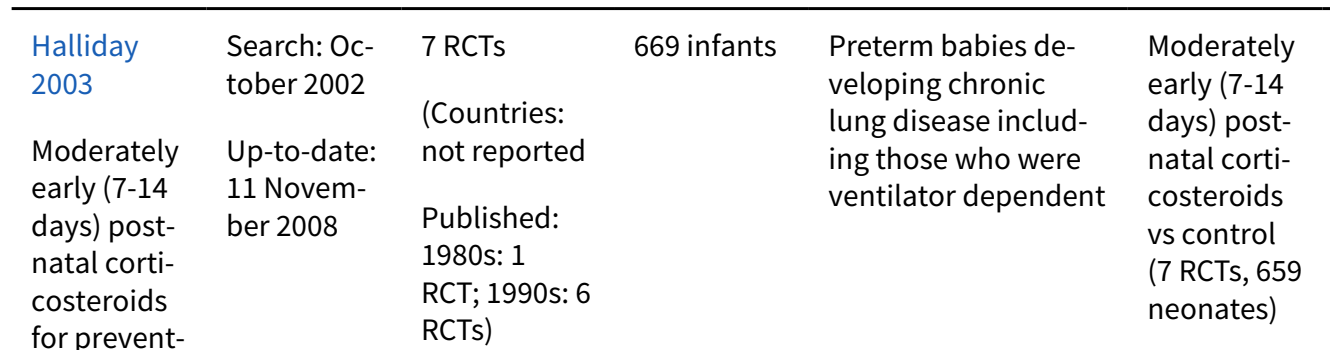
ing chronic lung disease in preterm infants

\section{Cerebral palsy ("Cerebral} palsy" (4 RCTs, 204 children); "Cerebral palsy in survivors assessed" (4 RCTs, 130 children); reported as review outcomes (not separated into primary and secondary))

\section{Cerebral palsy or death} ("Death or cerebral palsy" (4 RCTs, 204 children); reported as a review outcome)

Other composite outcomes that include cerebral palsy as a component ("Major neurosensory disability (variable criteria - see individual studies)" (2 RCTs, 96 children); "Major neurosensory disability (variable criteria) in survivors assessed" (2 RCTs, 56 children); "Death or major neurosensory disability (variable criteria)" (2 RCTs, 96 children); reported as review outcomes)

\begin{tabular}{|c|c|c|c|c|c|c|}
\hline $\begin{array}{l}\text { Doyle } 2014 \\
\text { Late (> } 7 \\
\text { days) post- } \\
\text { natal corti- } \\
\text { costeroids } \\
\text { for chron- } \\
\text { ic lung dis- }\end{array}$ & $\begin{array}{l}\text { Search: } \\
\text { August } \\
2013 \\
\text { Up-to-date: } \\
\text { 18 February } \\
2014\end{array}$ & $\begin{array}{l}21 \text { RCTs } \\
\text { (Countries: } \\
\text { Australia, } \\
\text { Canada, New } \\
\text { Zealand: } 1 \\
\text { RCT; } 6 \text { coun- } \\
\text { tries: } 1 \text { RCT; }\end{array}$ & $\begin{array}{l}1424 \text { in- } \\
\text { fants }\end{array}$ & $\begin{array}{l}\text { Preterm infants with } \\
\text { evolving or estab- } \\
\text { lished chronic lung } \\
\text { disease, defined as } \\
\text { oxygen-dependent, } \\
\text { ventilator-depen- } \\
\text { dent, or both, with or }\end{array}$ & $\begin{array}{l}\text { Late }(>7 \\
\text { days) post- } \\
\text { natal corti- } \\
\text { costeroids } \\
\text { vs con- } \\
\text { trol }(21 \\
\text { RCTs, } 1424 \\
\text { neonates) }\end{array}$ & $\begin{array}{l}\text { Cerebral palsy ("Cerebral pal- } \\
\text { sy: at } 1 \text { to } 3 \text { years" ( } 14 \text { RCTs, } 876 \\
\text { children); "Cerebral palsy: at } \\
\text { latest reported age" ( } 15 \text { RCTs, } \\
855 \text { children); "Cerebral pal- } \\
\text { sy in survivors assessed: at } 1 \\
\text { to } 3 \text { years" (14 RCTs, } 631 \text { chil- } \\
\text { dren); "Cerebral palsy in sur- }\end{array}$ \\
\hline
\end{tabular}


Table 2. Characteristics of included reviews (Continued) ease in preterm infants

not reported:

19 RCTs without radiographic changes of BPD

Published:

1980s: 5

RCTs; 1990s:

12 RCTs;

2000s: 3

RCTs; 2010s:

$1 \mathrm{RCT}$ ) vivors assessed: at latest reported age" (15 RCTs, 591 children); reported as primary outcomes)

Cerebral palsy or death

("Death or cerebral palsy: at 1 to 3 years" (14 RCTs, 876 children); "Death or cerebral palsy: at latest reported age" (15 RCTs, 855 children); reported as primary outcomes)

Other composite outcomes that include cerebral palsy as a component ("Major neurosensory disability (variable criteria - see individual studies)" (8 RCTs, 655 children); "Major neurosensory disability (variable criteria) in survivors assessed" (8 RCTs, 480 children); "Death or major neurosensory disability (variable criteria)" (8 RCTs, 655 children); reported as primary outcomes)

Motor dysfunction ("Bayley Psychomotor Developmental Index (PDI) <-2 SD" (1 RCT, 118 children); "Bayley PDI <-2 SD in survivors tested" (1 RCT, 90 children); reported as primary outcomes)

\begin{tabular}{|c|c|c|c|c|c|c|}
\hline $\begin{array}{l}\text { Shah } 2012 \\
\text { Early ad- } \\
\text { ministra- } \\
\text { tion of in- } \\
\text { haled corti- } \\
\text { costeroids } \\
\text { for prevent- } \\
\text { ing chron- } \\
\text { ic lung dis- } \\
\text { ease in ven- } \\
\text { tilated very } \\
\text { low birth } \\
\text { weight } \\
\text { preterm } \\
\text { neonates }\end{array}$ & $\begin{array}{l}29 \text { July } \\
2011\end{array}$ & $\begin{array}{l}7 \text { RCTs } \\
\text { (Countries: } \\
\text { Canada: } 1 \\
\text { RCT; China: } \\
\text { 1 RCT; Ger- } \\
\text { many: } 1 \text { RCT; } \\
\text { UK: } 1 \text { RCT; } \\
\text { USA: } 1 \text { RCT; } \\
\text { not reported: } \\
2 \text { RCTs } \\
\text { Published: } \\
\text { 1990s: } 5 \\
\text { RCTs; 2000s: } \\
2 \text { RCTs) }\end{array}$ & 495 infants & $\begin{array}{l}\text { Ventilator-de- } \\
\text { pendent preterm } \\
\text { neonates with birth- } \\
\text { weight } \leq 1500 \mathrm{~g} \text { and } \\
\text { postnatal age }<2 \\
\text { weeks }\end{array}$ & $\begin{array}{l}\text { Early in- } \\
\text { haled } \\
\text { steroids (< } \\
2 \text { weeks) vs } \\
\text { placebo ( } 7 \\
\text { RCTs, } 495 \\
\text { neonates) }\end{array}$ & $\begin{array}{l}\text { Cerebral palsy ("Cerebral pal- } \\
\text { sy" (1 RCT, } 56 \text { children); report- } \\
\text { ed as a secondary outcome) } \\
\text { Motor dysfunction ("Mean de- } \\
\text { velopmental index on BSID-II<2 } \\
\text { SD of the mean" ( } 1 \text { RCT, } 56 \text { chil- } \\
\text { dren); reported as a secondary } \\
\text { outcome) }\end{array}$ \\
\hline $\begin{array}{l}\text { Darlow } \\
2016 \\
\text { Vitamin } \\
\text { A supple- } \\
\text { menta- } \\
\text { tion to pre- } \\
\text { vent mor- } \\
\text { tality and } \\
\text { short- and }\end{array}$ & 1 May 2016 & $\begin{array}{l}11 \text { RCTs } \\
\text { (Countries: } \\
\text { Greece: } 1 \\
\text { RCT; South } \\
\text { Africa: } 1 \text { RCT; } \\
\text { Thailand: } 1 \\
\text { RCT; UK: } 2 \\
\text { RCTs; USA: } 6 \\
\text { RCTs }\end{array}$ & $\begin{array}{l}1580 \text { in- } \\
\text { fants }\end{array}$ & $\begin{array}{l}\text { VLBW infants (de- } \\
\text { fined as birthweight } \\
\leq 1500 \text { g or at less } \\
\text { than } 32 \text { weeks' ges- } \\
\text { tation) }\end{array}$ & $\begin{array}{l}\text { Supple- } \\
\text { mental vi- } \\
\text { tamin A } \\
\text { vs no sup- } \\
\text { plemen- } \\
\text { tation (10 } \\
\text { RCTs, } 1460 \\
\text { neonates) }\end{array}$ & $\begin{array}{l}\text { Other composite outcomes } \\
\text { that include cerebral palsy } \\
\text { as a component ("Neurode- } \\
\text { velopmental impairment at } 18 \\
\text { to } 22 \text { months" ( } 1 \mathrm{RCT}, 538 \text { chil- } \\
\text { dren); "Death or neurodevel- } \\
\text { opmental impairment at } 18 \text { to } \\
22 \text { months" (1 RCT, } 687 \text { chil- } \\
\text { dren); reported as secondary } \\
\text { outcomes) }\end{array}$ \\
\hline
\end{tabular}

Neonatal interventions for preventing cerebral palsy: an overview of Cochrane Systematic Reviews (Review) 
Table 2. Characteristics of included reviews (Continued)

$\begin{array}{ll}\text { long-term } & \text { Published: } \\ \text { morbidi- } & \text { 1980s: } 2 \\ \text { ty in very } & \text { RCTs; } 1990 \text { s: } \\ \text { low birth } & 4 \text { RCTs; } \\ \text { weight in- } & 2000 \text { : } 3 \\ \text { fants } & \text { RCTs: } 2010 \text { s: } \\ & 2 \text { RCTs) }\end{array}$

\begin{tabular}{|c|c|c|c|c|c|c|}
\hline $\begin{array}{l}\text { AlFaleh } \\
2014 \\
\text { Probiotics } \\
\text { for pre- } \\
\text { vention of } \\
\text { necrotis- } \\
\text { ing ente- } \\
\text { rocolitis in } \\
\text { preterm in- } \\
\text { fants }\end{array}$ & $\begin{array}{l}1 \text { October } \\
2013\end{array}$ & $\begin{array}{l}24 \text { RCTs } \\
\text { (Countries: } \\
\text { Australia } \\
\text { and New } \\
\text { Zealand: } 1 \\
\text { RCT; Brazil: } 1 \\
\text { RCT; Colom- } \\
\text { bia: } 1 \text { RCT; } \\
\text { France: } 1 \\
\text { RCT; Ger- } \\
\text { many: } \\
\text { 2 RCTs; } \\
\text { Greece: } 2 \\
\text { RCTs; India: } \\
\text { 1 RCT; Israel: } \\
\text { 1 RCT; Italy: } 4 \\
\text { RCTs; Japan: } \\
2 \text { RCTs; Tai- } \\
\text { wan: } 2 \text { RCTs; } \\
\text { Turkey: } 1 \\
\text { RCT; UK: } 1 \\
\text { RCT; USA: } \\
1 \text { RCT; not } \\
\text { reported; } 3 \\
\text { RCTs }\end{array}$ & $\begin{array}{l}5529 \text { in- } \\
\text { fants (20 } \\
\text { RCTs with } \\
\text { reported } \\
\text { outcomes) }\end{array}$ & $\begin{array}{l}\text { Preterm infants at < } \\
37 \text { weeks and birth- } \\
\text { weight }<2500 \mathrm{~g} \text {, or } \\
\text { both }\end{array}$ & $\begin{array}{l}\text { Probiotics } \\
\text { vs con- } \\
\text { trol ( } 20 \\
\text { RCTs, } 5529 \\
\text { neonates) }\end{array}$ & $\begin{array}{l}\text { Other composite outcome } \\
\text { that includes cerebral palsy as } \\
\text { a component ("Mental retarda- } \\
\text { tion and cerebral palsy" ( } 1 \mathrm{RCT} \text {, } \\
85 \text { children); reported as a sec- } \\
\text { ondary outcome) }\end{array}$ \\
\hline & & $\begin{array}{l}\text { Published: } \\
\text { 1980s: } 1 \\
\text { RCT; 1990s: } 2 \\
\text { RCTs; 2000s: } \\
\text { 12 RCTs; } \\
\text { 2010s: } 9 \\
\text { RCTs) }\end{array}$ & & & & \\
\hline $\begin{array}{l}\text { Shah } 2007 \\
\text { Arginine } \\
\text { supple- } \\
\text { mentation } \\
\text { for pre- } \\
\text { vention of } \\
\text { necrotis- } \\
\text { ing ente- } \\
\text { rocolitis in } \\
\text { preterm in- } \\
\text { fants }\end{array}$ & $\begin{array}{l}\text { Search: Au- } \\
\text { gust } 2010 \\
\text { Up-to-date: } \\
28 \text { Novem- } \\
\text { ber } 2010\end{array}$ & $\begin{array}{l}1 \mathrm{RCT} \\
\text { (Country: not } \\
\text { reported } \\
\text { Published; } \\
2000 \text { s) }\end{array}$ & 152 infants & $\begin{array}{l}\text { Preterm infants less } \\
\text { than } 37 \text { weeks' ges- } \\
\text { tation at birth }\end{array}$ & $\begin{array}{l}\text { Arginine } \\
\text { supple- } \\
\text { mentation } \\
\text { vs placebo } \\
\text { (1 RCT, } 152 \\
\text { neonates) }\end{array}$ & $\begin{array}{l}\text { Cerebral palsy ("Cerebral pal- } \\
\text { sy" ( } 1 \text { RCT, } 135 \text { children); report- } \\
\text { ed as a post hoc secondary out- } \\
\text { come) } \\
\text { Other composite outcome } \\
\text { that includes cerebral palsy as } \\
\text { a component ("Major neurode- } \\
\text { velopmental disability" ( } 1 \text { RCT, } \\
132 \text { children); reported as a post } \\
\text { hoc secondary outcome) }\end{array}$ \\
\hline
\end{tabular}


Table 2. Characteristics of included reviews (Continued)

\begin{tabular}{|c|c|c|c|c|c|c|}
\hline $\begin{array}{l}\text { Cleminson } \\
2015 \\
\text { Prophylac- } \\
\text { tic systemic } \\
\text { antifun- } \\
\text { gal agents } \\
\text { to pre- } \\
\text { vent mor- } \\
\text { tality and } \\
\text { morbidi- } \\
\text { ty in very } \\
\text { low birth } \\
\text { weight in- } \\
\text { fants }\end{array}$ & $\begin{array}{l}\text { Search: Au- } \\
\text { gust } 2015 \\
\text { Up-to-date: } \\
1 \text { Septem- } \\
\text { ber } 2015\end{array}$ & $\begin{array}{l}15 \text { RCTs } \\
\text { (Countries: } \\
\text { India: } 2 \text { RCTs; } \\
\text { Italy: } 2 \text { RCTs; } \\
\text { Korea: } 1 \text { RCT; } \\
\text { Saudi Ara- } \\
\text { bia: } 1 \text { RCT; } \\
\text { Turkey: } 2 \\
\text { RCTs; USA: } 7 \\
\text { RCTs } \\
\text { Published: } \\
\text { 2000s: } 7 \\
\text { RCTs; } 2010 s: \\
\text { 8 RCTs) }\end{array}$ & $\begin{array}{l}1690 \text { in- } \\
\text { fants }\end{array}$ & $\begin{array}{l}\text { Very preterm or } \\
\text { VLBW infants with or } \\
\text { without evidence of } \\
\text { fungal colonisation } \\
\text { but without evidence } \\
\text { of invasive fungal in- } \\
\text { fection at study entry }\end{array}$ & $\begin{array}{l}\text { Systemic } \\
\text { antifungal } \\
\text { agent vs } \\
\text { placebo or } \\
\text { no drug (10 } \\
\text { RCTs, } 1371 \\
\text { neonates) }\end{array}$ & $\begin{array}{l}\text { Cerebral palsy ("Cerebral pal- } \\
\text { sy" (1 RCT, } 219 \text { children); report- } \\
\text { ed as a primary outcome) } \\
\text { Other composite outcome } \\
\text { that includes cerebral palsy } \\
\text { as a component ("Neurodevel- } \\
\text { opmental impairment (compos- } \\
\text { ite)" ( } 1 \text { RCT, } 171 \text { children); re- } \\
\text { ported as a primary outcome) }\end{array}$ \\
\hline
\end{tabular}

Neonatal care: infections: herpes simplex

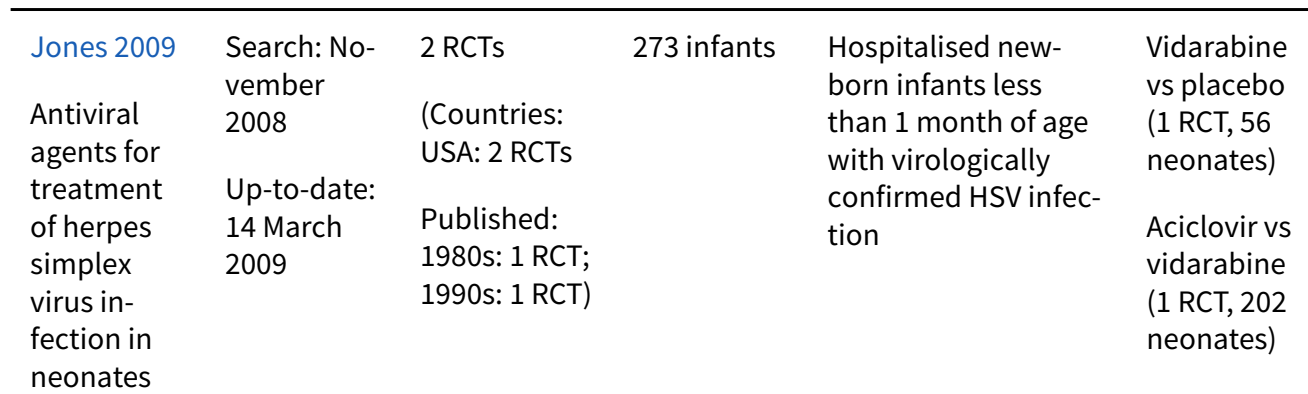

Cerebral palsy ("Cerebral palsy in CNS HSV neonatal infection up to three years by HSV serotype: HSV-1" (1 RCT, 9 children); "Cerebral palsy in CNS HSV neonatal infection up to three years by HSV serotype: HSV-2" (1 RCT, 14 children); reported as primary outcomes)

Other composite outcomes that include cerebral palsy as a component ("Abnormal neurodevelopment at one year" (1 RCT, 56 children; and 1 RCT, 202 children); "Abnormal neurodevelopment or death at approximately one year of age" (1 RCT, 56 children; and 1 RCT, 202 children); reported as primary outcomes)

\begin{tabular}{|c|c|c|c|c|c|c|}
\hline \multicolumn{7}{|c|}{ Neonatal care: jaundice } \\
\hline $\begin{array}{l}\text { Okwundu } \\
2012 \\
\text { Prophy- } \\
\text { lactic pho- } \\
\text { tothera- } \\
\text { py for pre- } \\
\text { venting } \\
\text { jaundice in } \\
\text { preterm or } \\
\text { low birth } \\
\text { weight in- } \\
\text { fants }\end{array}$ & $\begin{array}{l}31 \text { March } \\
2011\end{array}$ & $\begin{array}{l}9 \text { RCTs } \\
\text { (Countries: } \\
\text { USA: } 6 \text { RCTs; } \\
\text { Brazil: } 1 \text { RCT; } \\
\text { Canada: } 1 \\
\text { RCT; India: } 1 \\
\text { RCT } \\
\text { Published: } \\
\text { 1960s: } 2 \\
\text { RCTs; } 1970 \text { s: } \\
\text { 1 RCT; 1980s: } \\
\text { 2 RCTs; } \\
\text { 2000s: } 4 \\
\text { RCTs) }\end{array}$ & $\begin{array}{l}3449 \text { in- } \\
\text { fants }\end{array}$ & $\begin{array}{l}\text { 1. Preterm infants (< } \\
37 \text { weeks' gesta- } \\
\text { tion) } \\
\text { 2. LBW infants (< } \\
2500 \mathrm{~g}) \text {, within } \\
\text { first } 36 \text { hours of } \\
\text { birth } \\
\text { Originally (in the pro- } \\
\text { tocol), the focus of } \\
\text { the review was nar- } \\
\text { rower (to include } \\
\text { VLBW infants; }<1500 \\
\text { g birthweight); how- } \\
\text { ever, so as not to } \\
\text { lose valuable infor- } \\
\text { mation, we made a }\end{array}$ & $\begin{array}{l}\text { Prophy- } \\
\text { lactic pho- } \\
\text { tothera- } \\
\text { py vs con- } \\
\text { trol (9 } \\
\text { RCTs, } 3449 \\
\text { neonates) }\end{array}$ & $\begin{array}{l}\text { Cerebral palsy ("Cerebral pal- } \\
\text { sy" ( } 2 \text { RCTs, } 756 \text { children); re- } \\
\text { ported as a primary outcome) } \\
\text { Other composite outcomes } \\
\text { that include cerebral palsy as } \\
\text { a component ("Neurodevel- } \\
\text { opmental impairment" (1 RCT, } \\
1804 \text { children); reported as a } \\
\text { primary outcome) }\end{array}$ \\
\hline
\end{tabular}


Table 2. Characteristics of included reviews (Continued)

post hoc decision to
include any study
that involved LBW (<
$2500 \mathrm{~g}$ birthweight)
or preterm infants

We excluded studies of infants with a known cause that can lead to significant hyperbilirubinaemia, such as ABO incompatibility, Rh incompatibility, minor blood group incompatibility, or G-6PD deficiency

\section{Neonatal care: hypoglycaemia}

\begin{tabular}{|c|c|c|c|c|c|c|}
\hline $\begin{array}{l}\text { Weston } \\
2016 \\
\text { Oral dex- } \\
\text { trose gel for } \\
\text { the treat- } \\
\text { ment of } \\
\text { hypogly- } \\
\text { caemia in } \\
\text { newborn } \\
\text { infants }\end{array}$ & $\begin{array}{l}29 \text { February } \\
2016\end{array}$ & $\begin{array}{l}2 \text { RCTs } \\
\text { (Countries: } \\
\text { Ireland: } 1 \\
\text { RCT; New } \\
\text { Zealand: } 1 \\
\text { RCT; } \\
\text { Published: } \\
\text { 2000s: } 1 \text { RCT; } \\
\text { 2010s: } 1 \text { RCT) }\end{array}$ & 317 infants & $\begin{array}{l}\text { We included new- } \\
\text { born infants from } \\
\text { birth to discharge } \\
\text { home who were hy- } \\
\text { poglycaemic (blood } \\
\text { glucose concentra- } \\
\text { tions below the nor- } \\
\text { mal range, investi- } \\
\text { gator defined) for } \\
\text { any reason. We ex- } \\
\text { cluded infants who } \\
\text { had received prior IV } \\
\text { treatment for main- } \\
\text { tenance of glucose } \\
\text { control at the time of } \\
\text { hypoglycaemia }\end{array}$ & $\begin{array}{l}\text { Dextrose } \\
\text { gel vs con- } \\
\text { trol (2 } \\
\text { RCTs, } 317 \\
\text { neonates) }\end{array}$ & $\begin{array}{l}\text { Cerebral palsy ("Cerebral pal- } \\
\text { sy and severity at age } 2 \text { years or } \\
\text { older" ( } 1 \text { RCT, } 183 \text { children); re- } \\
\text { ported as a secondary outcome) } \\
\text { Other composite outcomes } \\
\text { that include cerebral palsy } \\
\text { as a component ("Major neu- } \\
\text { rosensory disability ( } 2 \text {-year fol- } \\
\text { low-up)" (1 RCT, } 184 \text { children); } \\
\text { reported as a primary outcome) } \\
\text { ("Developmental disability at } \\
\text { age } 2 \text { years or older" (1 RCT, } 184 \\
\text { children); reported as a sec- } \\
\text { ondary outcome) }\end{array}$ \\
\hline
\end{tabular}

\section{Neonatal care: parenteral feeding}

\begin{tabular}{|c|c|c|c|c|c|c|}
\hline $\begin{array}{l}\text { Moe-Byrne } \\
2016 \\
\text { Glutamine } \\
\text { supple- } \\
\text { mentation } \\
\text { to prevent } \\
\text { morbidity } \\
\text { and mor- } \\
\text { tality in } \\
\text { preterm in- } \\
\text { fants }\end{array}$ & $\begin{array}{l}18 \text { Decem- } \\
\text { ber } 2015\end{array}$ & $\begin{array}{l}12 \text { RCTs } \\
\text { (Countries: } \\
\text { China; } 1 \\
\text { RCT; Greece: } \\
1 \text { RCT; } \\
\text { Malaysia: } \\
\text { 1 RCT; } \\
\text { Nether- } \\
\text { lands: } 1 \text { RCT; } \\
\text { Turkey: } 1 \\
\text { RCT; UK: } 1 \\
\text { RCT; USA: } 4 \\
\text { RCTs; not re- } \\
\text { ported; } \\
2 \text { RCTs; } \\
\text { Published: } \\
\text { 1990s: } 2 \\
\text { RCTs; } 2000 \text { s: } \\
6 \text { RCTs; }\end{array}$ & $\begin{array}{l}2877 \text { in- } \\
\text { fants }\end{array}$ & $\begin{array}{l}\text { We included preterm } \\
\text { infants (gestational } \\
\text { age }<37 \text { weeks) ad- } \\
\text { mitted to neonatal } \\
\text { intensive or special } \\
\text { care units or com- } \\
\text { parable settings af- } \\
\text { ter birth. When par- } \\
\text { ticipants in a trial } \\
\text { included both term } \\
\text { and preterm infants, } \\
\text { we sought subgroup } \\
\text { data from the report } \\
\text { or from trial authors }\end{array}$ & $\begin{array}{l}\text { Glutamine } \\
\text { supple- } \\
\text { mentation } \\
\text { vs no sup- } \\
\text { plemen- } \\
\text { tation (12 } \\
\text { RCTs, } 2877 \\
\text { neonates) }\end{array}$ & $\begin{array}{l}\text { Other composite outcome } \\
\text { that includes cerebral palsy as } \\
\text { a component ("Neurodevelop- } \\
\text { mental impairment" ( } 1 \text { RCT, } 72 \\
\text { children); reported as a primary } \\
\text { outcome) }\end{array}$ \\
\hline
\end{tabular}


Table 2. Characteristics of included reviews (Continued)

2010s: 4

RCTs)

\section{Neonatal care: other}

\begin{tabular}{|c|c|c|c|c|c|c|}
\hline $\begin{array}{l}\text { Osborn } \\
2001 \\
\text { Thyroid } \\
\text { hormones } \\
\text { for prevent- } \\
\text { ing neu- } \\
\text { rodevelop- } \\
\text { mental im- } \\
\text { pairment in } \\
\text { preterm in- } \\
\text { fants }\end{array}$ & $\begin{array}{l}\text { Search: } \\
\text { June } 2001 \\
\text { Up-to-date: } \\
1 \text { February } \\
2009\end{array}$ & $\begin{array}{l}5 \text { RCTs } \\
\text { (Countries: } \\
\text { not reported; } \\
\text { Published: } \\
\text { 1980s: } 2 \\
\text { RCTs; 1990s: } \\
2 \text { RCTs; } \\
\text { 2000s; } 1 \text { RCT) }\end{array}$ & 362 infants & $\begin{array}{l}\text { Studies that enrolled } \\
\text { and treated preterm } \\
\text { infants in the neona- } \\
\text { tal period }\end{array}$ & $\begin{array}{l}\text { Thyroid } \\
\text { hormones } \\
\text { vs control } \\
\text { (5 RCTs, } 362 \\
\text { neonates) }\end{array}$ & $\begin{array}{l}\text { Cerebral palsy ("Cerebral pal- } \\
\text { sy in survivors" (1 RCT, } 156 \text { chil- } \\
\text { dren); reported as a primary } \\
\text { outcome) } \\
\text { Cerebral palsy or death } \\
\text { ("Death or cerebral palsy" (1 } \\
\text { RCT, } 200 \text { children); reported as a } \\
\text { primary outcome) }\end{array}$ \\
\hline
\end{tabular}

\begin{tabular}{|c|c|c|c|c|c|c|}
\hline $\begin{array}{l}\text { Osborn } \\
2007 \\
\text { Prophylac- } \\
\text { tic postna- } \\
\text { tal thyroid } \\
\text { hormones } \\
\text { for preven- } \\
\text { tion of mor- } \\
\text { bidity and } \\
\text { mortality in } \\
\text { preterm in- } \\
\text { fants }\end{array}$ & $\begin{array}{l}\text { Search: } \\
\text { March } 2006 \\
\text { Up-to-date: } \\
12 \text { October } \\
2006\end{array}$ & $\begin{array}{l}4 \text { RCTs } \\
\text { (Countries: } \\
\text { not reported; } \\
\text { Published: } \\
\text { 1990s: } 2 \\
\text { RCTs; 2000s: } \\
\text { 2 RCTs) }\end{array}$ & 318 infants & $\begin{array}{l}\text { Studies that enrolled } \\
\text { preterm infants } \\
\text { (born < } 37 \text { completed } \\
\text { weeks' gestation) in } \\
\text { the neonatal period. } \\
\text { Trials that enrolled } \\
\text { infants on the basis } \\
\text { of results of abnor- } \\
\text { mal thyroid function } \\
\text { tests (known congen- } \\
\text { ital hypothyroidism } \\
\text { or transient hypothy- } \\
\text { roxinaemia), or with } \\
\text { only respiratory dis- } \\
\text { tress syndrome, were } \\
\text { excluded }\end{array}$ & $\begin{array}{l}\text { Prophylac- } \\
\text { tic thyroid } \\
\text { hormones } \\
\text { vs no thy- } \\
\text { roid hor- } \\
\text { mones ( } 4 \\
\text { RCTs, } 318 \\
\text { neonates) }\end{array}$ & $\begin{array}{l}\text { Cerebral palsy ("Cerebral pal- } \\
\text { sy in survivors" ( } 1 \text { RCT, } 156 \text { chil- } \\
\text { dren); reported as a primary } \\
\text { outcome) } \\
\text { Cerebral palsy or death } \\
\text { ("Death or cerebral palsy" (1 } \\
\text { RCT, } 200 \text { children); reported as a } \\
\text { primary outcome) }\end{array}$ \\
\hline
\end{tabular}

\begin{tabular}{|c|c|c|c|c|c|c|}
\hline $\begin{array}{l}\text { Almadhoob } \\
2015 \\
\text { Sound re- } \\
\text { duction } \\
\text { manage- } \\
\text { ment in the } \\
\text { neonatal } \\
\text { intensive } \\
\text { care unit } \\
\text { for preterm } \\
\text { or very } \\
\text { low birth } \\
\text { weight in- } \\
\text { fants }\end{array}$ & $\begin{array}{l}18 \text { Decem- } \\
\text { ber } 2014\end{array}$ & $\begin{array}{l}1 \text { RCT } \\
\text { (Country: } \\
\text { USA; } \\
\text { Published: } \\
\text { 2009) }\end{array}$ & 34 infants & $\begin{array}{l}\text { Preterm infants (< } \\
32 \text { weeks' post-men- } \\
\text { strual age or }<1500 \\
\text { g birthweight) cared } \\
\text { for in the resusci- } \\
\text { tation area, during } \\
\text { transport, or once } \\
\text { admitted to an NICU } \\
\text { or a stepdown unit }\end{array}$ & $\begin{array}{l}\text { Silicone } \\
\text { earplugs vs } \\
\text { no earplugs } \\
\text { ( } 1 \text { RCT, } 34 \\
\text { infants) }\end{array}$ & $\begin{array}{l}\text { Cerebral palsy ("Cerebral pal- } \\
\text { sy at } 18 \text { to } 22 \text { months' corrected } \\
\text { age" ( } 1 \text { RCT, } 14 \text { children); report- } \\
\text { ed as a primary outcome) }\end{array}$ \\
\hline $\begin{array}{l}\text { Conde- } \\
\text { Agudelo } \\
2016 \\
\text { Kangaroo } \\
\text { mother } \\
\text { care to re- } \\
\text { duce mor- } \\
\text { bidity and } \\
\text { mortality in }\end{array}$ & $\begin{array}{l}30 \text { June } \\
2016\end{array}$ & $\begin{array}{l}21 \text { RCTs } \\
\text { (Countries: } \\
13 \text { RCTs } \\
\text { in low- or } \\
\text { middle-in- } \\
\text { come coun- } \\
\text { tries: Colom- } \\
\text { bia: } 1 \text { RCT; } \\
\text { Ecuador: }\end{array}$ & $\begin{array}{l}3042 \text { in- } \\
\text { fants }\end{array}$ & $\begin{array}{l}\text { LBW infants (defined } \\
\text { as birthweight }<2500 \\
\text { g) regardless of ges- } \\
\text { tational age }\end{array}$ & $\begin{array}{l}\text { Kangaroo } \\
\text { mother } \\
\text { care vs con- } \\
\text { vention- } \\
\text { al neona- } \\
\text { tal care ( } 20 \\
\text { RCTs, } 2969 \\
\text { neonates) }\end{array}$ & $\begin{array}{l}\text { Cerebral palsy ("Cerebral palsy } \\
\text { at } 12 \text { months' corrected age" ( } 1 \\
\text { RCT, } 588 \text { children); reported as a } \\
\text { primary outcome) }\end{array}$ \\
\hline
\end{tabular}


Table 2. Characteristics of included reviews (Continued)

$\begin{array}{ll}\text { low birth- } & 1 \text { RCT; } \\ \text { weight in- } & \text { Ethiopia: } 1 \\ \text { fants } & \text { RCT; Indone- } \\ & \text { sia, Mexico, } \\ & \text { Ethiopia: } 1 \\ & \text { RCT; Indone- } \\ & \text { sia: } 1 \text { RCT; In- } \\ & \text { dia: } 8 \text { RCTs; } \\ & \text { Madagas- } \\ \text { car: } 1 \text { RCT; } & \text { Malaysia: } 1 \\ & \text { RCT; Nepal: } 1 \\ \text { RCT; } 5 \text { RCTs } \\ \text { in high-in- } \\ \text { come coun- } \\ \text { tries: Aus- } \\ \text { tralia: } 1 \\ \text { RCT; United } \\ \text { Kingdom: } 1 \\ \text { RCT; Unit- } \\ \text { ed States: } \\ \text { 3 RCTs; } \\ \text { Published: } \\ \text { 1990s: 5 } \\ \text { RCTs; } 2000 \text { s: } \\ \text { 10 RCTs; } \\ \text { 2010s: } 6 \\ \text { RCTs) } \\ \end{array}$

\begin{tabular}{|c|c|c|c|c|c|c|}
\hline $\begin{array}{l}\text { Spittle } 2015 \\
\text { Early devel- } \\
\text { opmental } \\
\text { interven- } \\
\text { tion pro- } \\
\text { grammes } \\
\text { provided } \\
\text { post hos- } \\
\text { pital dis- } \\
\text { charge to } \\
\text { prevent } \\
\text { motor and } \\
\text { cognitive } \\
\text { impairment } \\
\text { in preterm } \\
\text { infants }\end{array}$ & $\begin{array}{l}15 \text { August } \\
2015\end{array}$ & $\begin{array}{l}25 \text { RCTs } \\
\text { (Countries: } \\
\text { not reported; } \\
\text { Published: } \\
\text { 1970s: } 1 \\
\text { RCT; 1980s: } 5 \\
\text { RCTs; 1990s: } \\
\text { 3 RCTs; } \\
\text { 2000s: 13 } \\
\text { RCTs; 2010s: } \\
\text { 3 RCTs) }\end{array}$ & $\begin{array}{l}3615 \text { in- } \\
\text { fants }\end{array}$ & $\begin{array}{l}\text { Preterm infants born } \\
\text { at }<37 \text { weeks' gesta- } \\
\text { tional age (accord- } \\
\text { ing to best obstetri- } \\
\text { cal estimate at the } \\
\text { time of delivery). We } \\
\text { excluded studies that } \\
\text { did not report out- } \\
\text { comes for preterm } \\
\text { infants separately } \\
\text { from those for in- } \\
\text { fants born at term }\end{array}$ & $\begin{array}{l}\text { Early de- } \\
\text { velopmen- } \\
\text { tal inter- } \\
\text { vention } \\
\text { vs stan- } \\
\text { dard fol- } \\
\text { low-up ( } 25 \\
\text { RCTs, } 3615 \\
\text { neonates) }\end{array}$ & $\begin{array}{l}\text { Cerebral palsy ("Rate of cere- } \\
\text { bral palsy" ( } 7 \text { RCTs, } 985 \text { chil- } \\
\text { dren); reported as a secondary } \\
\text { outcome) } \\
\text { Motor dysfunction ("Motor } \\
\text { outcome at school age (low } \\
\text { score on Movement ABC)" ( } 2 \\
\text { RCTs, } 333 \text { children); reported as } \\
\text { a secondary outcome) }\end{array}$ \\
\hline
\end{tabular}

Abbreviations: BP: blood pressure; BPD: bronchopulmonary dysplasia; BSID: Bayley Scales of Infant Development; CNS: central nervous system; ECHO: echocardiogram; g: grams; G-6PD: glucose-6-phosphate dehydrogenase; HSV: herpes simplex virus; IPPV: intermittent positive-pressure ventilation; IV: intravenous; LBW: low birthweight; MDI: Mental Development Index; Movement-ABC: Movement Assessment Battery for Children; NICU: neonatal intensive care unit; NO: nitric oxide; PDA: patent ductus arteriosus; PDI: Psychomotor Development Index; PMA: post-menstrual age; PPHN: persistent pulmonary hypertension of the newborn; RCT: randomised controlled trial; Rh: Rhesus; SBF: systemic blood flow; SD: standard deviation; SVC: superior vena cava; VLBW: very low birthweight.

Table 3. Risk of bias assessments from included reviews

Review ID and title Summary of trial limitations (risk of bias)*


Table 3. Risk of bias assessments from included reviews (Continued)

\section{Neonatal care: asphyxia}

\section{Chaudhari 2012}

Allopurinol for preventing mortality and morbidity in newborn infants with hypoxic-ischaemic encephalopathy
Random sequence generation: 2 RCTs low risk; 1 RCT unclear risk

Allocation concealment: 3 RCTs low risk

Blinding: 2 RCTs low risk; 1 RCT high risk

Incomplete outcome data: 3 RCTs low risk

Overall: "Although small, the trials were generally of good methodological quality"

Random sequence generation: 9 RCTs low risk; 1 RCT unclear risk; 1 RCT high risk

Allocation concealment: 8 RCTs low risk; 2 RCTs unclear risk; 1 RCT high risk

Blinding (participants and personnel): $11 \mathrm{RCTs}$ high risk

Blinding (outcome assessors): 10 RCTs low risk; 1 RCT unclear risk

Incomplete outcome data: 6 RCTs low risk; 1 RCT unclear risk; 4 RCTs high risk

Selective reporting: $11 \mathrm{RCTs}$ low risk

Overall: "Several limitations of the available evidence should be noted"

Random sequence generation: 7 RCTs low risk; 2 RCTs unclear risk

Allocation concealment: 4 RCTs low risk; 4 RCTs unclear risk; 1 RCT high risk

Blinding: 4 RCTs unclear risk; 5 RCTs high risk

Incomplete outcome data: 6 RCTs low risk; 2 RCTs unclear risk; 1 RCT high risk

Selective reporting: 9 RCTs low risk

\section{Neonatal care: haemorrhage: periventricular/intraventricular}

\section{Hunt 2010}

Ethamsylate for the prevention of morbidity and mortality in preterm or very low birth weight infants
Adequate sequence generation: 4 RCTs yes; 2 RCTs unclear; 1 RCT no

Allocation concealment: 3 RCTs yes; 2 RCT unclear; 2 RCTs no

Blinding: 4 RCTs yes; 3 RCTs unclear

Incomplete outcome data addressed: 5 RCTs yes; 1 RCT unclear; 1 RCT no

Free of selective reporting: 7 RCTs yes

Free of other bias: 7 RCTs yes

Random sequence generation: 5 RCTs low risk; 6 RCTs unclear risk; 1 RCT high risk

Allocation concealment: 4 RCTs low risk; 7 RCTs unclear risk; 1 RCT high risk

Blinding (participants and personnel): 2 RCTs low risk; 10 RCTs high risk

Blinding (outcome assessors): 6 RCTs low risk; 6 RCTs unclear risk

Incomplete outcome data: 8 RCTs low risk; 4 RCTs unclear risk

Selective reporting: 2 RCTs low risk; 10 RCTs unclear risk

\footnotetext{
Neonatal care: hypotension
} 
Table 3. Risk of bias assessments from included reviews (Continued)

\section{Osborn 2007b}

The effect of inotropes on morbidity and mortality in preterm infants with low systemic or organ blood flow

\author{
Adequate sequence generation: 1 RCT yes \\ Allocation concealment: 1 RCT yes \\ Blinding (outcomes): 1 RCT yes \\ Blinding (intervention): 1 RCT yes \\ Incomplete outcome data addressed: 1 RCT yes \\ Free of selective reporting: 1 RCT yes \\ Free of other bias: 1 RCT yes \\ Overall: "The study was of adequate methodology"
}

\section{Neonatal care: fluid therapy}

\section{Osborn 2004}

Early volume expansion for prevention of morbidity and mortality in very preterm infants

\author{
Adequate randomisation: 7 RCTs yes; 1 RCT unclear \\ Allocation concealment: 7 RCTs yes; 1 RCT unclear \\ Blinding of intervention: 1 RCT yes; 7 RCTs no \\ Blinding of measurement: 3 RCTs yes; 1 RCT unclear; 4 RCTs no \\ Losses to follow-up: 5 RCTs none; 1 RCT unclear; 2 RCTs yes
}

\section{Neonatal care: patent ductus arteriosus}

\section{Fowlie 2010}

Prophylactic intravenous indomethacin for preventing mortality and morbidity in preterm infants

Blinding of randomisation: 12 RCTs yes; 7 RCTs can't tell

Blinding of intervention: 16 RCTs yes; 2 RCTs can't tell; 1 RCT no

Blinding of outcome assessment: 16 RCTs yes; 2 RCTs can't tell; 1 RCT no

Complete follow-up (short-term outcomes): 18 RCTs yes; 1 RCT no

Overall: "Overall, the quality of the trials was good"

\section{Ohlsson 2015}

Ibuprofen for the treatment of patent ductus arteriosus in preterm or low birth weight (or both) infants
Random sequence generation: 9 RCTs low risk; 24 RCTs unclear risk

Allocation concealment: 18 RCTs low risk; 14 RCTs unclear risk; 1 RCT high risk

Blinding: 6 RCTs low risk; 7 RCTs unclear risk; 20 RCTs high risk

Incomplete outcome data: 28 RCTs low risk; 3 RCTs unclear risk; 2 RCTs high risk

Selective reporting: 5 RCTs low risk; 28 RCTs unclear risk

Other: 29 RCTs low risk; 4 RCTs unclear risk

Overall: "Study quality was variable...we identified concerns about bias in most individual studies and therefore for the group of studies included as well"

\section{Neonatal care: blood disorders}

\footnotetext{
Ohlsson 2014

Early erythropoietin for preventing red blood cell transfusion in preterm and/or low birth weight infants
}

Random sequence generation: 8 RCTs low: risk; 19 RCTs unclear risk

Allocation concealment: 13 RCTs low risk; 14 RCTs unclear risk

Blinding: 12 RCTs low risk; 3 RCTs unclear risk; 12 RCTs high risk

Incomplete outcome data: 23 RCTs low risk; 2 RCTs unclear risk; 2 RCTs high risk 
Table 3. Risk of bias assessments from included reviews (Continued)

Selective reporting: 1 RCT low risk; 26 RCTs unclear risk

Other: 26 RCTs low risk; 1 RCT unclear risk

Whyte 2011

Low versus high haemoglobin concentration threshold for blood transfusion for preventing morbidity and mortality in very low birth weight infants
Allocation concealment: 4 RCTs low risk; 1 RCT unclear risk

Blinding: 1 RCT unclear risk; 4 RCTs high risk

Incomplete outcome data: 3 RCTs low risk; 1 RCT unclear risk; 1 RCT high risk

Selective reporting: 1 RCT low risk; 3 RCTs unclear risk; 1 RCT high risk

Overall: "This review consists of five randomised controlled trials in which there appears to be no allocation bias; the overall level of evidence is high"

\section{Neonatal care: pulmonary hypertension}

\section{More 2016}

Endothelin receptor antagonists for persistent pulmonary hypertension in term and late preterm infants
Random sequence generation: 1 RCT low risk; 1 RCT unclear risk

Allocation concealment: 2 RCT unclear risk

Blinding (participants and personnel): 2 RCTs low risk

Blinding (outcome assessors): 2 RCTs low risk

Incomplete outcome data: 1 RCT low risk; 1 RCT high risk

Selective reporting: 1 RCT low risk; 1 RCT unclear risk

Other: 2 RCTs low risk

Overall: "the quality of evidence was considered low because of the very small sample size and methodological issues in the included studies"

\section{Neonatal care: resuscitation}

\section{Tan 2005}

Air versus oxygen for resuscitation of infants at birth

\section{Concealment of allocation: 2 RCTs yes; 3 RCTs no}

Blinding of intervention: 2 RCTs yes; 3 RCTs no

Blinding of outcome assessment: 2 RCTs yes; 3 RCTs no

Completeness of follow-up (short-term): 4 RCTs yes; 1 RCT no

Completeness of follow-up (long-term): 3 RCTs no; 2 RCTs unclear

\section{Neonatal care: nitric oxide}

Barrington 2010

Inhaled nitric oxide for respiratory failure in preterm infants
Allocation concealment: 12 RCTs low risk; 2 RCTs unclear risk

Blinding: 7 RCTs low risk; 7 RCTs high risk

Incomplete outcome data: 14 RCTs low risk

Selective reporting: 8 RCTs low risk; 6 RCTs not reported

Other: 3 RCTs low risk; 4 RCTs high risk; 7 RCTs not reported

\section{Finer 2006}

Nitric oxide for respiratory failure in infants born at or near term

\section{Masking of allocation: 10 RCTs yes; 4 RCTs cannot tell}

Masking of intervention: 6 RCTs yes; 8 RCTs no

Masking of outcome assessment: 6 RCTs yes; 1 RCT can't tell; 7 RCTs no 
Table 3. Risk of bias assessments from included reviews (Continued)

Completeness of follow-up: 13 RCTs yes; 1 RCT can't tell

Overall: "The overall quality of these studies is quite variable"

\section{Neonatal care: apnoea}

Henderson-Smart 2010b

Methylxanthine treatment for apnoea in preterm infants

Random sequence generation: 1 RCT high risk; 5 RCTs not reported

Allocation concealment: 2 RCTs low risk; 2 RCTs unclear risk; 2 RCTs high risk

Blinding: 4 RCTs low risk; 2 RCTs high risk

Incomplete outcome data: 3 RCTs low risk; 1 RCT unclear risk; 2 RCTs high risk

Selective reporting: 2 RCTs low risk; 1 RCT unclear risk; 2 RCTs high risk; 1 RCT not reported

Overall: "There was variation in trial design"

Henderson-Smart 2010c

Prophylactic methylxanthine for prevention of apnoea in preterm infants

\section{Allocation concealment: 3 RCTs low risk}

Blinding: 3 RCTs low risk

Incomplete outcome data: 3 RCTs low risk

Selective reporting: 2 RCTs low risk; 1 RCT not reported

Overall: "Three studies are generally of high quality"

\section{Neonatal care: respiratory distress syndrome}

\section{Howlett 2015}

Inositol in preterm infants at risk for or having respiratory distress syndrome
Random sequence generation: 1 RCT low risk; 3 RCTs unclear risk

Allocation concealment: 2 RCTs low risk; 2 RCTs unclear risk

Blinding: 2 RCTs low risk; 2 RCTs unclear risk

Incomplete outcome data: 4 RCTs low risk

Selective reporting: 3 RCTs low risk; 1 RCT unclear risk

Other: 3 RCTs high risk; 1 RCT low risk

Overall: "Study quality varied and interim analyses had occurred in all trials"

\section{Seger 2009}

Animal derived surfactant extract for treatment of respiratory distress syndrome

Blinding of randomisation: 10 RCTs yes; 3 RCTs not described

Blinding of intervention: 8 RCTs yes; 1 RCT not described; 4 RCTs no

Blinding of outcome measurement: 6 RCTs yes; 4 RCTs not described; 2 RCTs no; 1 RCT not reported

Complete follow-up (short-term): 13 RCTs yes

Complete follow-up (long-term): 4 RCTs yes; 9 RCTs no

Overall: "studies are of high methodological quality"

\section{Soll 2000}

Synthetic surfactant for respiratory distress syndrome in preterm infants
Blinding of randomisation: 6 RCTs yes

Blinding of intervention: 5 RCTs yes; 1 RCT no

Blinding of outcome measurement: 5 RCTs yes; 1 RCT no

Complete follow-up (short term): 6 RCTs yes 
Table 3. Risk of bias assessments from included reviews (Continued)

Complete follow-up (long term): 80 to $100 \%$

\section{Soll 2010}

Prophylactic protein free synthetic surfactant for preventing morbidity and mortality in preterm infants
Adequate sequence generation: 6 RCTs unclear: 1 RCT not reported

Allocation concealment: 7 RCTs yes

Blinding of intervention: 5 RCTs yes; 1 RCT unclear; 1 RCT no

Blinding of outcome measurement: 6 RCTs yes; 1 RCT no

Incomplete outcome data addressed: 5 RCTs yes; 2 RCTs unclear

Free of selective reporting: 7 RCTs yes

Free of other bias: 7 RCTs yes

\section{Neonatal care: mechanical ventilation}

\section{Cools 2015}

Elective high frequency oscillatory ventilation versus conventional ventilation for acute pulmonary dysfunction in preterm infants

Random sequence generation: 11 RCTs low risk; 8 RCTs unclear risk

Allocation concealment: 7 RCTs low risk; 12 RCTs unclear risk

Blinding of participants and personnel: 19 RCTs high risk

Blinding of outcome assessment: 7 RCTs low risk; 12 RCTs unclear risk

Incomplete outcome data: 19 RCTs low risk

Overall: "The quality of the studies was generally high"

\section{Ho 2015}

Continuous distending pressure for respiratory distress in preterm infants
Random sequence generation: 2 RCTs low risk; 3 RCTs unclear risk; 1 RCT high risk

Allocation concealment: 4 RCTs low risk; 1 RCT unclear risk; 1 RCT high risk

Blinding (intervention): 6 RCTs high risk

Blinding (short term outcomes): 6 RCTs high risk (1 RCT low risk for long term outcomes)

Incomplete outcome data (short term outcomes): 3 RCTs low risk; 3 RCTs unclear risk (1 RCT low risk for long-term outcomes)

Selective reporting: 2 RCTs low risk; 4 RCTs unclear risk

Other: 6 RCTs unclear risk

Overall: "These data should be interpreted with caution as in the studies reviewed, the numbers of infants were small, blinding of treatment was not possible and blinding of the outcome assessment was reported in only one study for the outcomes in childhood, thus possibly introducing bias"
Henderson-Smart 2010

Prophylactic methylxanthines for endotracheal extubation in preterm infants

\section{Sequence generation: 1 RCT low risk; 6 RCTs not reported}

Allocation concealment: 6 RCTs low risk; 1 RCT unclear risk

Blinding: 6 RCTs low risk; 1 RCT high risk

Incomplete outcome data: 3 RCTs low risk; 3 RCTs high risk; 1 RCT not reported

Selective reporting: 4 RCTs low risk; 2 RCTs high risk; 1 RCT not reported

Other: 1 RCT low risk; 6 RCTs not reported

Concealment of allocation: 1 RCT yes; 1 RCT cannot tell; 3 RCTs no

Blinding of intervention: 5 RCTs no 
Table 3. Risk of bias assessments from included reviews (Continued)

Long versus short inspiratory times in neonates receiving mechanical ventilation
Blinding of outcome measurement: 3 RCTs no; 2 RCTs some

Completeness of follow-up (short term outcomes): 5 RCTs yes

\section{Wheeler 2010}

Volume-targeted versus pressure-limited ventilation in the neonate

\section{Sequence generation: 6 RCTs low risk; 6 RCTs unclear risk}

Allocation concealment: 11 RCTs low risk; 1 RCT unclear risk

Blinding: 12 RCTs high risk

Incomplete outcome data: 12 RCTs low risk

Selective reporting: 10 RCTs low risk; 1 RCT unclear risk; 1 RCT high risk

Other: 5 RCTs low risk; 5 RCTs unclear risk; 2 RCTs high risk

Overall: "There are no major concerns about the methodology used in the twelve trials included in this review"

\section{Neonatal care: bronchopulmonary dysplasia}

\section{Doyle 2014b}

Early (< 8 days) postnatal corticosteroids for preventing chronic lung disease in preterm infants

Random sequence generation: 15 RCTs low risk; 14 RCTs unclear risk

Allocation concealment: 27 RCTs low risk; 2 RCTs unclear risk

Blinding of participants and personnel: 23 RCTs low risk; 2 RCTs unclear risk; 4 RCTs high risk

Blinding of outcome assessment: 23 RCTs low risk; 2 RCTs unclear risk; 4 RCTs high risk

Incomplete outcome data: $28 \mathrm{RCTs}$ low risk; 1 RCT unclear risk

Overall: "Overall the risk of bias was low for most studies"

\section{Halliday 2003}

Moderately early (7-14 days) postnatal corticosteroids for preventing chronic lung disease in preterm infants
Blinding of randomisation/allocation concealment: 7 RCTs yes/low risk

Blinding of intervention: 5 RCTs yes; 2 RCTs no

Blinding of outcome measurement: 5 RCTs yes; 1 RCT some; 1 RCT cannot tell

Complete follow-up: 6 RCTs yes/almost; 1 RCT no

Overall: "the methodological quality of the studies to determine long-term outcome is limited in some cases"

\section{Doyle 2014}

Late (> 7 days) postnatal corticosteroids for chronic lung disease in preterm infants
Random sequence generation: 12 RCTs low risk; 9 RCTs unclear risk

Allocation concealment: 17 RCTs low risk; 4 RCTs unclear risk

Blinding of participants and personnel: 15 RCTs low risk; 4 RCTs unclear risk; 2 RCTs high risk

Blinding of outcome assessment: 16 RCTs low risk; 4 RCTs unclear risk; 1 RCT high risk

Incomplete outcome data: 20 RCTs low risk; 1 RCT unclear risk

Overall: "Overall the risk of bias was low for most studies"

\section{Shah 2012}

Early administration of inhaled corticosteroids for preventing chronic lung disease in ventilated very low birth weight preterm neonates
Random sequence generation: 7 RCTs unclear risk

Allocation concealment: 7 RCTs low risk

Blinding of participants and personnel: 7 RCTs low risk

Blinding of outcome assessment: 1 RCT low risk; 6 RCTs unclear risk

Incomnlete outcome data: 6 RCTs low risk: 1 RCT unclear risk

Neonatal interventions for preventing cerebral palsy: an overview of Cochrane Systematic Reviews (Review) Copyright $\odot 2018$ The Cochrane Collaboration. Published by John Wiley \& Sons, Ltd. 
Table 3. Risk of bias assessments from included reviews (Continued)

Overall: "Overall, the studies included for this review were of high methodological quality"

\section{Darlow 2016}

Vitamin A supplementation to prevent mortality and shortand long-term morbidity in very low birth weight infants
Random sequence generation: 9 RCTs low risk; 2 RCTs unclear risk

Allocation concealment: 8 RCTs low risk; 3 RCTs unclear risk

Blinding: 6 RCTs low risk; 2 RCTs unclear risk; 3 RCTs high risk

Incomplete outcome data: 9 RCTs low risk; 1 RCT unclear risk; 1 RCT high risk

Selective reporting: 8 RCTs low risk; 2 RCTs unclear risk; 1 RCT high risk

Other: 2 RCTs low risk; 6 RCTs unclear risk; 2 RCTs high risk; 1 RCT not reported

\section{Neonatal care: infections: necrotising enterocolitis}

\section{AlFaleh 2014}

Probiotics for prevention of necrotising enterocolitis in preterm infants
Random sequence generation: 15 RCTs low risk; 8 RCTs unclear risk; 1 RCT high risk

Allocation concealment: 11 RCTs low risk; 12 RCTs unclear risk; 1 RCT high risk

Blinding: 15 RCTs low risk; 9 RCTs unclear risk

Incomplete outcome data: 21 RCTs low risk; 2 RCTs unclear risk; 1 RCT high risk

Selective reporting: 17 RCTs low risk; 6 RCTs high risk; 1 RCT not reported

Other: 14 RCTs low risk; 10 RCTs not reported

Overall: "Eleven of our included trials were classified as high quality trials"

\section{Shah 2007}

Arginine supplementation for prevention of necrotising enterocolitis in preterm infants
Masking of randomisation: 1 RCT yes

Masking of intervention: 1 RCT yes

Masking of outcome assessment: 1 RCT yes

Completeness of follow-up: 1 RCT yes

Overall: "The methodological quality of the included study was good"

\section{Neonatal care: infections: fungal infections}

\section{Cleminson 2015}

Prophylactic systemic antifungal agents to prevent mortality and morbidity in very low birth weight infants

\section{Allocation concealment: 12 RCTs low risk; 3 RCTs unclear risk}

Blinding of participants and personnel: 10 RCTs low risk; 3 RCTs unclear risk; 2 RCTs high risk

Blinding of outcome assessment: 10 RCTs low risk; 3 RCTs unclear risk; 2 RCTs high risk Incomplete outcome data: 15 RCTs low risk

Overall: "The included trials were generally of good methodological quality"

\section{Neonatal care: infections: herpes simplex}

\section{Jones 2009}

Antiviral agents for treatment of herpes simplex virus infection in neonates
Allocation concealment: 1 RCT unclear; 1 RCT inadequate

Overall: "The two trials... have a number of methodological flaws"

\section{Neonatal care: jaundice}


Table 3. Risk of bias assessments from included reviews (Continued)

Prophylactic phototherapy for preventing jaundice in preterm or low birth weight infants

Allocation concealment: 3 RCTs low risk; 4 RCTs unclear risk; 2 RCTs high risk

Blinding: 1 RCT low risk; 2 RCTs unclear risk; 6 RCTs high risk

Incomplete outcome data: 8 RCTs low risk; 1 RCT high risk

Selective reporting: 2 RCTs low risk; 7 RCTs unclear risk

Other: 7 RCTs low risk

Overall: "In general, the overall methodological quality of the included studies was acceptable"

\section{Neonatal care: hypoglycaemia}

Weston 2016

Oral dextrose gel for the treatment of hypoglycaemia in newborn infants
Random sequence generation: 1 RCT low risk; 1 RCT unclear risk

Allocation concealment: 1 RCT low risk; 1 RCT unclear risk

Blinding of participants and personnel: 1 RCT low risk; 1 RCT unclear risk

Blinding of outcome assessors: 1 RCT low risk; 1 RCT unclear risk

Incomplete outcome data: 1 RCT low risk; 1 RCT high risk

Selective reporting: 1 RCT low risk; 1 RCT unclear risk

Other: 1 RCT low risk; 1 RCT unclear risk

\section{Neonatal care: parenteral feeding}

\section{Moe-Byrne 2016}

Glutamine supplementation to prevent morbidity and mortality in preterm infants
Random sequence generation: 8 RCTs low risk; 3 RCTs unclear risk; 1 RCT high risk

Allocation concealment: 8 RCTs low risk; 2 RCTs unclear risk; 2 RCTs high risk

Blinding: 10 RCTs low risk; 2 RCTs unclear risk

Incomplete outcome data: 8 RCTs low risk; 2 RCTs unclear risk; 2 RCTs high risk

Overall: "in general the trials were of good quality"

\section{Neonatal care: other}

\section{Osborn 2001}

Thyroid hormones for preventing neurodevelopmental impairment in preterm infants

\section{Blinding of randomisation/allocation concealment: 4 RCTs yes; 1 RCT no}

Blinding of intervention: 4 RCTs yes; 1 RCT no

Blinding of outcome assessment: 4 RCTs yes; 1 RCT not stated

Complete follow-up: 2 RCTs yes; 3 RCTs no

Overall: "four studies... were of good methodology"

\section{Osborn 2007}

Prophylactic postnatal thyroid hormones for prevention of morbidity and mortality in preterm infants

\section{Allocation concealment: 4 RCTs low risk}

Blinding of intervention: 4 RCTs yes

Blinding of outcome assessment: 3 RCTs yes; 1 RCT probably

Complete follow-up: 3 RCTs yes; 1 RCT no

Overall: "All studies... were of adequate methodology"

\section{Almadhoob $2015 \quad$ Random sequence generation: 1 RCT low risk}

Allocation concealment: 1 RCT low risk 
Table 3. Risk of bias assessments from included reviews (Continued)

Sound reduction management Blinding of participants and personnel: 1 RCT high risk in the neonatal intensive care unit for preterm or very low

Blinding of outcome assessment: 1 RCT low risk

birth weight infants

Incomplete outcome data: 1 RCT low risk

Selective reporting: 1 RCT low risk

Other: 1 RCT low risk

Overall: "We considered the overall risk of bias to be low"

\section{Conde-Agudelo 2016}

Kangaroo mother care to reduce morbidity and mortality in low birthweight infants
Random sequence generation: 21 RCTs low risk

Allocation concealment: 10 RCTs low risk; 11 RCTs unclear risk

Blinding of participants and personnel: 21 RCTs high risk

Blinding of outcome assessment: 2 RCTs low risk; 15 RCTs unclear risk; 4 RCTs high risk

Incomplete outcome data: 14 RCTs low risk; 3 RCTs unclear risk; 4 RCTs high risk

Selective reporting: 16 RCTs low risk; 3 RCTs unclear risk; 2 RCTs high risk

Other: 15 RCTs low risk; 3 RCTs unclear risk; 3 RCTs high risk

Overall: "The methodological quality of the included trials was mixed"

\section{Spittle 2015}

Early developmental intervention programmes provided post hospital discharge to prevent motor and cognitive impairment in preterm infants
Random sequence generation: 11 RCTs low risk; 8 RCTs unclear risk; 5 RCTs high risk; 1 RCT not reported

Allocation concealment: 11 RCTs low risk; 9 RCTs unclear risk; 5 RCTs high risk

Blinding of participants and personnel: 2 RCTs low risk; 4 RCTs unclear risk; 19 RCTs high risk

Blinding of outcome assessment: 21 RCTs low risk; 3 RCTs unclear risk; 1 RCT high risk

Incomplete outcome data: 12 RCTs low risk; 4 RCTs unclear risk; 9 RCT high risk

Selective reporting: 3 RCTs unclear risk; 6 RCT high risk; 16 RCTs not reported

Overall: "The methodological quality of included studies was variable"

Abbreviations: RCT: randomised controlled trial.

*We have reported only the risk of bias components assessed and reported in the included reviews. 


\begin{tabular}{|c|c|c|c|c|c|c|c|c|c|c|c|c|}
\hline \multirow[t]{2}{*}{ Review ID } & \multicolumn{11}{|c|}{ AMSTAR criteria } & \multirow[t]{2}{*}{ TOTAL SCORE } \\
\hline & $\begin{array}{l}\text { 'A priori' } \\
\text { design }\end{array}$ & $\begin{array}{l}\text { Dupli- } \\
\text { cate se- } \\
\text { lection } \\
\text { and ex- } \\
\text { traction }\end{array}$ & $\begin{array}{l}\text { Compre- } \\
\text { hensive } \\
\text { search }\end{array}$ & $\begin{array}{l}\text { Grey lit- } \\
\text { erature } \\
\text { consid- } \\
\text { ered }\end{array}$ & $\begin{array}{l}\text { Includ- } \\
\text { ed and } \\
\text { exclud- } \\
\text { ed stud- } \\
\text { ies lists }\end{array}$ & $\begin{array}{l}\text { Char- } \\
\text { acteris- } \\
\text { tics of } \\
\text { included } \\
\text { studies }\end{array}$ & $\begin{array}{l}\text { Quali- } \\
\text { ty as- } \\
\text { sessed } \\
\text { and doc- } \\
\text { ument- } \\
\text { ed }\end{array}$ & $\begin{array}{l}\text { Quality } \\
\text { consid- } \\
\text { ered for } \\
\text { conclu- } \\
\text { sions }\end{array}$ & $\begin{array}{l}\text { Methods } \\
\text { for com- } \\
\text { bining } \\
\text { studies } \\
\text { appro- } \\
\text { priate }\end{array}$ & $\begin{array}{l}\text { Publica- } \\
\text { tion bias } \\
\text { consid- } \\
\text { ered } \\
\text { or as- } \\
\text { sessed }\end{array}$ & $\begin{array}{l}\text { Con- } \\
\text { flicts } \\
\text { stated }\end{array}$ & \\
\hline \multicolumn{13}{|c|}{ Neonatal care: asphyxia } \\
\hline Chaudhari 2012 & $\checkmark$ & $\checkmark$ & $\checkmark$ & $\checkmark$ & $\checkmark$ & $\checkmark$ & $\checkmark$ & $\checkmark$ & $\checkmark$ & $\checkmark$ & $\#$ & $\begin{array}{l}\text { 10/11 } \\
\text { HIGH QUALITY }\end{array}$ \\
\hline Jacobs 2013 & $\checkmark$ & $\checkmark$ & $\checkmark$ & $\checkmark$ & $\checkmark$ & $\checkmark$ & $\checkmark$ & $\checkmark$ & $\checkmark$ & \# & $\checkmark$ & $\begin{array}{l}\text { 10/11 } \\
\text { HIGH QUALITY }\end{array}$ \\
\hline Young 2016 & $\checkmark$ & $\checkmark$ & $\checkmark$ & $\checkmark$ & $\checkmark$ & $\checkmark$ & $\checkmark$ & $\checkmark$ & $\checkmark$ & $\checkmark$ & $\#$ & $\begin{array}{l}\text { 10/11 } \\
\text { HIGH QUALITY }\end{array}$ \\
\hline \multicolumn{13}{|c|}{ Neonatal care: haemorrhage: periventricular/intraventricular } \\
\hline Hunt 2010 & $\checkmark$ & $\checkmark$ & $\checkmark$ & $\checkmark$ & $\checkmark$ & $\checkmark$ & $\checkmark$ & $\checkmark$ & $\checkmark$ & \# & \# & $\begin{array}{l}\text { 9/11 } \\
\text { HIGH QUALITY }\end{array}$ \\
\hline Smit 2013 & $\checkmark$ & $\checkmark$ & $\checkmark$ & $\checkmark$ & $\checkmark$ & $\checkmark$ & $\checkmark$ & $\checkmark$ & $\checkmark$ & $\checkmark$ & $\#$ & $\begin{array}{l}\text { 10/11 } \\
\text { HIGH QUALITY }\end{array}$ \\
\hline \multicolumn{13}{|c|}{ Neonatal care: hypotension } \\
\hline Osborn 2007b & $\checkmark$ & $\checkmark$ & $\checkmark$ & $\checkmark$ & $\checkmark$ & $\checkmark$ & $\checkmark$ & $\checkmark$ & $\mathrm{N} / \mathrm{A}$ & $\checkmark$ & \# & $\begin{array}{l}9 / 10 \\
\text { HIGH QUALITY }\end{array}$ \\
\hline \multicolumn{13}{|c|}{ Neonatal care: fluid therapy } \\
\hline Osborn 2004 & $\checkmark$ & $\checkmark$ & $\checkmark$ & $\checkmark$ & $\checkmark$ & $\checkmark$ & $\checkmark$ & $\checkmark$ & $\checkmark$ & \# & $\#$ & $\begin{array}{l}\text { 9/11 } \\
\text { HIGH QUALITY }\end{array}$ \\
\hline
\end{tabular}




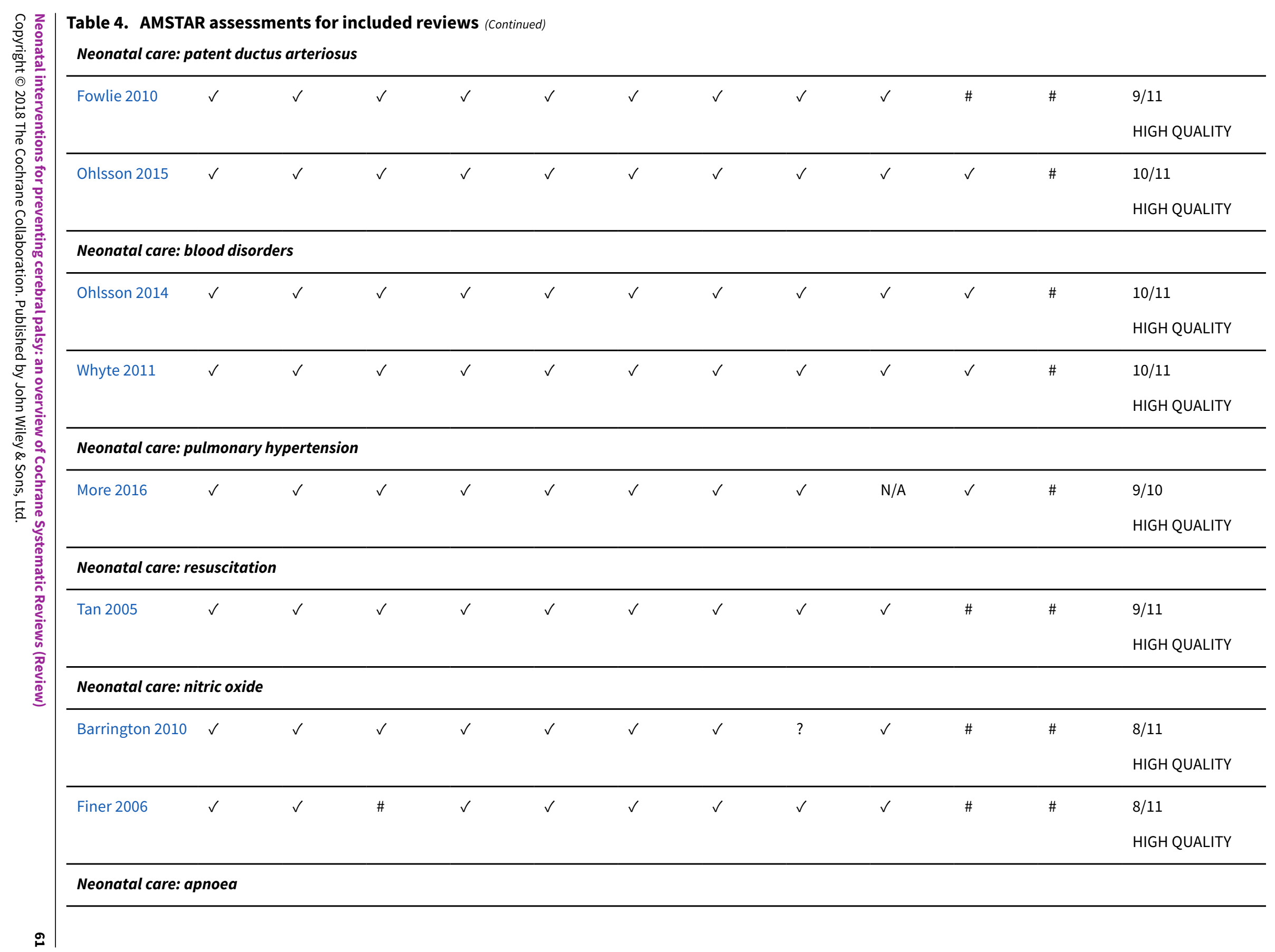




\begin{tabular}{|c|c|c|c|c|c|c|c|c|c|c|c|c|}
\hline $\begin{array}{l}\text { Hender- } \\
\text { son-Smart } \\
2010 \mathrm{~b}\end{array}$ & $\checkmark$ & $\checkmark$ & $\checkmark$ & $\checkmark$ & $\checkmark$ & $\checkmark$ & $\checkmark$ & $\checkmark$ & $\checkmark$ & $\#$ & $\#$ & $\begin{array}{l}9 / 11 \\
\text { HIGH QUALITY }\end{array}$ \\
\hline $\begin{array}{l}\text { Hender- } \\
\text { son-Smart } \\
2010 c\end{array}$ & $\checkmark$ & $\checkmark$ & $\checkmark$ & $\checkmark$ & $\checkmark$ & $\checkmark$ & $\checkmark$ & $\checkmark$ & $\checkmark$ & $\#$ & \# & $\begin{array}{l}9 / 11 \\
\text { HIGH QUALITY }\end{array}$ \\
\hline \multicolumn{13}{|c|}{ Neonatal care: respiratory distress syndrome } \\
\hline Howlett 2015 & $\checkmark$ & $\checkmark$ & $\checkmark$ & $\checkmark$ & $\checkmark$ & $\checkmark$ & $\checkmark$ & $\checkmark$ & $\checkmark$ & $\checkmark$ & \# & $\begin{array}{l}\text { 10/11 } \\
\text { HIGH QUALITY }\end{array}$ \\
\hline Seger 2009 & $?$ & $\checkmark$ & $\checkmark$ & $\checkmark$ & $\checkmark$ & $\checkmark$ & $\checkmark$ & $\checkmark$ & $\checkmark$ & $\#$ & \# & $\begin{array}{l}8 / 11 \\
\text { HIGH QUALITY }\end{array}$ \\
\hline Soll 2000 & $?$ & $?$ & $\checkmark$ & $\checkmark$ & $\checkmark$ & $\checkmark$ & $\checkmark$ & $\checkmark$ & $?$ & $\#$ & $\#$ & $\begin{array}{l}6 / 11 \\
\text { MODERATE } \\
\text { QUALITY }\end{array}$ \\
\hline Soll 2010 & $\checkmark$ & $\checkmark$ & $\checkmark$ & $\checkmark$ & $\checkmark$ & $\checkmark$ & $\checkmark$ & $\checkmark$ & $\checkmark$ & \# & \# & $\begin{array}{l}9 / 11 \\
\text { HIGH QUALITY }\end{array}$ \\
\hline \multicolumn{13}{|c|}{ Neonatal care: mechanical ventilation } \\
\hline Cools 2015 & $\checkmark$ & $\checkmark$ & $\checkmark$ & $\checkmark$ & $\checkmark$ & $\checkmark$ & $\checkmark$ & $\checkmark$ & $\checkmark$ & $\#$ & \# & $\begin{array}{l}9 / 11 \\
\text { HIGH QUALITY }\end{array}$ \\
\hline Ho 2015 & $\checkmark$ & $\checkmark$ & $\checkmark$ & $\checkmark$ & $\checkmark$ & $\checkmark$ & $\checkmark$ & $\checkmark$ & $\checkmark$ & \# & \# & $\begin{array}{l}\text { 9/11 } \\
\text { HIGH QUALITY }\end{array}$ \\
\hline $\begin{array}{l}\text { Hender- } \\
\text { son-Smart } 2010\end{array}$ & $\checkmark$ & $\checkmark$ & $\checkmark$ & $\checkmark$ & $\#$ & $\checkmark$ & $\checkmark$ & $\checkmark$ & $\checkmark$ & \# & \# & $\begin{array}{l}8 / 11 \\
\text { HIGH QUALITY }\end{array}$ \\
\hline Kamlin 2003 & $\checkmark$ & $\checkmark$ & $\checkmark$ & $\checkmark$ & $\checkmark$ & $\checkmark$ & $\checkmark$ & $\checkmark$ & $\checkmark$ & $\#$ & $\#$ & $\begin{array}{l}9 / 11 \\
\text { HIGH QUALITY }\end{array}$ \\
\hline
\end{tabular}




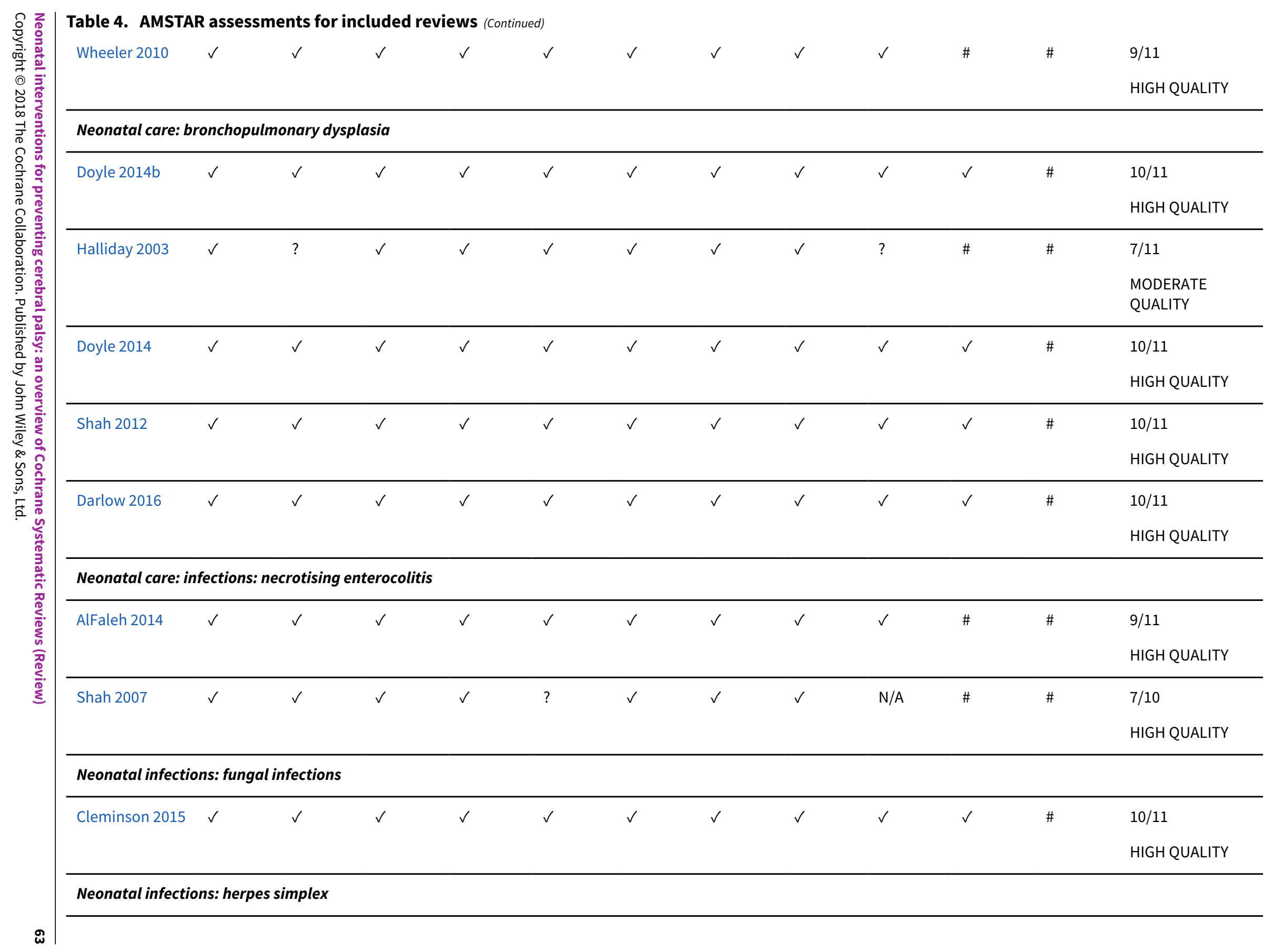




\begin{tabular}{|c|c|c|c|c|c|c|c|c|c|c|c|c|}
\hline Jones 2009 & $\checkmark$ & $\checkmark$ & $\checkmark$ & $\checkmark$ & $\checkmark$ & $\checkmark$ & $\checkmark$ & $\checkmark$ & $\mathrm{N} / \mathrm{A}$ & $\#$ & \# & $\begin{array}{l}8 / 10 \\
\text { HIGH QUALITY }\end{array}$ \\
\hline \multicolumn{13}{|c|}{ Neonatal care: jaundice } \\
\hline Okwundu 2012 & $\checkmark$ & $\checkmark$ & $\checkmark$ & $\checkmark$ & $\checkmark$ & $\checkmark$ & $\checkmark$ & $\checkmark$ & $?$ & $\#$ & $\#$ & $\begin{array}{l}8 / 11 \\
\text { HIGH QUALITY }\end{array}$ \\
\hline \multicolumn{13}{|c|}{ Neonatal care: hypoglycaemia } \\
\hline Weston 2016 & $\checkmark$ & $\checkmark$ & $\checkmark$ & $\checkmark$ & $\checkmark$ & $\checkmark$ & $\checkmark$ & $\checkmark$ & $\checkmark$ & $\checkmark$ & $\checkmark$ & $\begin{array}{l}\text { 11/11 } \\
\text { HIGH QUALITY }\end{array}$ \\
\hline \multicolumn{13}{|c|}{ Neonatal care: parenteral feeding } \\
\hline Moe-Byrne 2016 & $\checkmark$ & $\checkmark$ & $\checkmark$ & $\checkmark$ & $\checkmark$ & $\checkmark$ & $\checkmark$ & $\checkmark$ & $\checkmark$ & $\checkmark$ & $\#$ & $\begin{array}{l}\text { 10/11 } \\
\text { HIGH QUALITY }\end{array}$ \\
\hline \multicolumn{13}{|c|}{ Neonatal care: other } \\
\hline Osborn 2001 & $\checkmark$ & $?$ & $\checkmark$ & $\checkmark$ & $\checkmark$ & $\checkmark$ & $\checkmark$ & $\checkmark$ & $\checkmark$ & $\#$ & $\#$ & $\begin{array}{l}8 / 11 \\
\text { HIGH QUALITY }\end{array}$ \\
\hline Osborn 2007 & $\checkmark$ & $\checkmark$ & $\checkmark$ & $\checkmark$ & $\checkmark$ & $\checkmark$ & $\checkmark$ & $\checkmark$ & $\checkmark$ & $\#$ & $\#$ & $\begin{array}{l}9 / 11 \\
\text { HIGH QUALITY }\end{array}$ \\
\hline $\begin{array}{l}\text { Almadhoob } \\
2015\end{array}$ & $\checkmark$ & $\checkmark$ & $\checkmark$ & $\checkmark$ & $\checkmark$ & $\checkmark$ & $\checkmark$ & $\checkmark$ & $\mathrm{N} / \mathrm{A}$ & $\checkmark$ & $\#$ & $\begin{array}{l}9 / 10 \\
\text { HIGH QUALITY }\end{array}$ \\
\hline $\begin{array}{l}\text { Conde-Agudelo } \\
2016\end{array}$ & $\checkmark$ & $\checkmark$ & $\checkmark$ & $\checkmark$ & $\checkmark$ & $\checkmark$ & $\checkmark$ & $\checkmark$ & $\checkmark$ & $\checkmark$ & $\#$ & $\begin{array}{l}\text { 10/11 } \\
\text { HIGH QUALITY }\end{array}$ \\
\hline Spittle 2015 & $\checkmark$ & $\checkmark$ & $\checkmark$ & $\checkmark$ & $\checkmark$ & $\checkmark$ & $\checkmark$ & $\checkmark$ & $\checkmark$ & $\#$ & $\#$ & $\begin{array}{l}\text { 9/11 } \\
\text { HIGH QUALITY }\end{array}$ \\
\hline
\end{tabular}


Table 5. ROBIS assessments for included reviews

\begin{tabular}{|c|c|c|c|c|c|}
\hline \multirow[t]{2}{*}{ Review ID } & \multicolumn{4}{|l|}{ ROBIS domains } & \multirow{2}{*}{$\begin{array}{l}\text { OVERALL RISK } \\
\text { OF BIAS }\end{array}$} \\
\hline & $\begin{array}{l}\text { Study eligibility } \\
\text { criteria }\end{array}$ & $\begin{array}{l}\text { Identification } \\
\text { and selection of } \\
\text { studies }\end{array}$ & $\begin{array}{l}\text { Data collection } \\
\text { and study ap- } \\
\text { praisal }\end{array}$ & $\begin{array}{l}\text { Synthesis and } \\
\text { findings }\end{array}$ & \\
\hline
\end{tabular}

\section{Neonatal care: asphyxia}

\begin{tabular}{|c|c|c|c|c|c|}
\hline Chaudhari 2012 & Low risk & Low risk & Low risk & Low risk & LOW RISK \\
\hline Jacobs 2013 & Low risk & Low risk & Low risk & Low risk & LOW RISK \\
\hline Young 2016 & Low risk & Low risk & Low risk & Low risk & LOW RISK \\
\hline
\end{tabular}

Neonatal care: haemorrhage: periventricular/intraventricular

\begin{tabular}{llllll}
\hline Hunt 2010 & Low risk & Low risk & Low risk & Low risk & LOW RISK \\
\hline Smit 2013 & Low risk & Low risk & Low risk & Low risk & LOW RISK \\
\hline
\end{tabular}

\section{Neonatal care: hypotension}

\begin{tabular}{|c|c|c|c|c|c|}
\hline Osborn 2007b & Low risk & Low risk & Low risk & Low risk & LOW RISK \\
\hline \multicolumn{6}{|c|}{ Neonatal care: fluid therapy } \\
\hline Osborn 2004 & Low risk & Low risk & Low risk & Low risk & LOW RISK \\
\hline \multicolumn{6}{|c|}{ Neonatal care: patent ductus arteriosus } \\
\hline Fowlie 2010 & Low risk & Low risk & Low risk & Low risk & LOW RISK \\
\hline Ohlsson 2015 & Low risk & Low risk & Low risk & Low risk & LOW RISK \\
\hline
\end{tabular}

Neonatal care: blood disorders

\begin{tabular}{llllll}
\hline Ohlsson 2014 & Low risk & Low risk & Low risk & Low risk & LOW RISK \\
\hline Whyte 2011 & Low risk & Low risk & Low risk & Low risk & LOW RISK \\
\hline
\end{tabular}

\section{Neonatal care: pulmonary hypertension}

\begin{tabular}{|c|c|c|c|c|c|}
\hline More 2016 & Low risk & Low risk & Low risk & Low risk & LOW RISK \\
\hline \multicolumn{6}{|c|}{ Neonatal care: resuscitation } \\
\hline Tan 2005 & Low risk & Low risk & Low risk & Low risk & LOW RISK \\
\hline \multicolumn{6}{|c|}{ Neonatal care: nitric oxide } \\
\hline Barrington 2010 & Low risk & Low risk & Low risk & Low risk & LOW RISK \\
\hline Finer 2006 & Low risk & Unclear risk & Low risk & Low risk & UNCLEAR RISK \\
\hline
\end{tabular}

\section{Neonatal care: apnoea}


Table 5. ROBIS assessments for included reviews (Continued)

\begin{tabular}{|c|c|c|c|c|c|}
\hline Henderson-Smart 2010b & Low risk & Low risk & Low risk & Low risk & LOW RISK \\
\hline Henderson-Smart 2010c & Low risk & Low risk & Low risk & Low risk & LOW RISK \\
\hline \multicolumn{6}{|c|}{ Neonatal care: respiratory distress syndrome } \\
\hline Howlett 2015 & Low risk & Low risk & Low risk & Low risk & LOW RISK \\
\hline Seger 2009 & Unclear risk & Low risk & Low risk & Low risk & LOW RISK \\
\hline Soll 2000 & Unclear risk & Unclear risk & Unclear risk & Unclear risk & UNCLEAR RISK \\
\hline Soll 2010 & Low risk & Low risk & Low risk & Low risk & LOW RISK \\
\hline \multicolumn{6}{|c|}{ Neonatal care: mechanical ventilation } \\
\hline Cools 2015 & Low risk & Low risk & Low risk & Low risk & LOW RISK \\
\hline Ho 2015 & Low risk & Low risk & Low risk & Low risk & LOW RISK \\
\hline Henderson-Smart 2010 & Low risk & Low risk & Low risk & Low risk & LOW RISK \\
\hline Kamlin 2003 & Low risk & Low risk & Low risk & Low risk & LOW RISK \\
\hline Wheeler 2010 & Low risk & Low risk & Low risk & Low risk & LOW RISK \\
\hline \multicolumn{6}{|c|}{ Neonatal care: bronchopulmonary dysplasia } \\
\hline Doyle 2014b & Low risk & Low risk & Low risk & Low risk & LOW RISK \\
\hline Halliday 2003 & Low risk & Unclear risk & Unclear risk & Unclear risk & LOW RISK \\
\hline Doyle 2014 & Low risk & Low risk & Low risk & Low risk & LOW RISK \\
\hline Shah 2012 & Low risk & Low risk & Low risk & Low risk & LOW RISK \\
\hline Darlow 2016 & Low risk & Low risk & Low risk & Low risk & LOW RISK \\
\hline
\end{tabular}

\section{Neonatal infections: necrotising enterocolitis}

\begin{tabular}{llllll}
\hline AlFaleh 2014 & Low risk & Low risk & Low risk & Low risk & LOW RISK \\
\hline Shah 2007 & Low risk & Low risk & Low risk & Low risk & LOW RISK \\
\hline
\end{tabular}

\section{Neonatal infections: fungal infections}

\begin{tabular}{llllll}
\hline Cleminson 2015 & Low risk & Low risk & Low risk & Low risk & LOW RISK \\
\hline \multicolumn{2}{l}{ Neonatal infections: herpes simplex } & & & & LOW RISK \\
\hline Jones 2009 & Low risk & Low risk & Low risk & Low risk & \\
\hline Neonatal care: jaundice & & & & Unclear risk & LOW RISK \\
\hline Okwundu 2012 & Low risk & Low risk & Low risk & &
\end{tabular}


Table 5. ROBIS assessments for included reviews (Continued) Neonatal care: hypoglycaemia

\begin{tabular}{|c|c|c|c|c|c|}
\hline Weston 2016 & Low risk & Low risk & Low risk & Low risk & LOW RISK \\
\hline \multicolumn{6}{|c|}{ Neonatal care: parenteral feeding } \\
\hline Moe-Byrne 2016 & Low risk & Low risk & Low risk & Low risk & LOW RISK \\
\hline \multicolumn{6}{|l|}{ Neonatal care: other } \\
\hline Osborn 2001 & Low risk & Unclear risk & Unclear risk & Low risk & UNCLEAR RISK \\
\hline Osborn 2007 & Low risk & Low risk & Low risk & Low risk & LOW RISK \\
\hline Almadhoob 2015 & Unclear risk & Low risk & Low risk & Low risk & LOW RISK \\
\hline Conde-Agudelo 2016 & Low risk & Low risk & Low risk & Low risk & LOW RISK \\
\hline Spittle 2015 & Low risk & Low risk & Low risk & Low risk & LOW RISK \\
\hline
\end{tabular}




\begin{tabular}{|c|c|c|c|c|c|c|c|}
\hline $\begin{array}{l}\text { Intervention and com- } \\
\text { parison }\end{array}$ & Outcome & $\begin{array}{l}\text { Assumed risk } \\
\text { with com- } \\
\text { parator }\end{array}$ & $\begin{array}{l}\text { Correspond- } \\
\text { ing risk with } \\
\text { intervention }\end{array}$ & $\begin{array}{l}\text { Relative ef- } \\
\text { fect }(95 \% \mathrm{Cl})\end{array}$ & $\begin{array}{l}\text { Number of } \\
\text { participants } \\
\text { (trials) }\end{array}$ & $\begin{array}{l}\text { Quality of } \\
\text { the evidence } \\
\text { (GRADE) }\end{array}$ & Comments \\
\hline \multicolumn{8}{|l|}{ Neonatal care: asphyxia } \\
\hline \multirow[t]{2}{*}{$\begin{array}{l}\text { Therapeutic hypother- } \\
\text { mia vs standard care for } \\
\text { newborns with hypoxic-is- } \\
\text { chaemic encephalopathy } \\
\text { (Jacobs 2013) }\end{array}$} & $\begin{array}{l}\text { Cerebral palsy } \\
\text { in survivors as- } \\
\text { sessed at } 18 \text { to } 24 \\
\text { months }\end{array}$ & $\begin{array}{l}352 \text { per } 1000 \\
(143 / 406)\end{array}$ & $\begin{array}{l}232 \text { per } 1000 \\
(190 \text { to } 289)\end{array}$ & $\begin{array}{l}\text { RR } 0.66(0.54 \\
\text { to } 0.82)\end{array}$ & 881 (7 RCTs) & $\mathrm{HIGH}$ & Not downgraded \\
\hline & $\begin{array}{l}\text { Cerebral palsy at } \\
6 \text { to } 7 \text { years }\end{array}$ & $\begin{array}{l}288 \text { per } 1000 \\
(15 / 52)\end{array}$ & $\begin{array}{l}173 \text { per } 1000 \\
(89 \text { to } 340)\end{array}$ & $\begin{array}{l}\text { RR } 0.60(0.31 \\
\text { to } 1.18)\end{array}$ & $121(1 \mathrm{RCT})$ & LOW & $\begin{array}{l}\text { Imprecision (-2): wide } \mathrm{Cl} \text { crossing } \\
\text { line of no effect; } 1 \mathrm{RCT} \text { with small } \\
\text { sample size }\end{array}$ \\
\hline $\begin{array}{l}\text { Barbiturates (phenobarbi- } \\
\text { tal) vs conventional thera- } \\
\text { py for prevention of mor- } \\
\text { bidity and mortality fol- } \\
\text { lowing perinatal asphyxia } \\
\text { (Young 2016) }\end{array}$ & $\begin{array}{l}\text { Cerebral palsy at } \\
3 \text { to } 6 \text { years }\end{array}$ & $\begin{array}{l}242 \text { per } 1000 \\
(8 / 33)\end{array}$ & $\begin{array}{l}141 \text { per } 1000 \\
(46 \text { to } 412)\end{array}$ & $\begin{array}{l}\text { RR } 0.58(0.19 \\
\text { to } 1.70)\end{array}$ & 69 (2 RCTs) & VERY LOW & $\begin{array}{l}\text { Study limitations (-1): unblinded } \\
\text { studies; concern regarding per- } \\
\text { formance bias and detection bias } \\
\text { Imprecision (-1): } 95 \% \text { Cls were } \\
\text { wide and imprecise } \\
\text { Inconsistency (-1): clinically im- } \\
\text { portant heterogeneity noted } \\
\text { (GRADED by review authors them- } \\
\text { selves) }\end{array}$ \\
\hline \multicolumn{8}{|c|}{ Neonatal care: haemorrhage: periventricular/intraventricular } \\
\hline $\begin{array}{l}\text { Ethamsylate vs placebo } \\
\text { for prevention of mor- } \\
\text { bidity and mortality in } \\
\text { preterm or very low birth- } \\
\text { weight infants (Hunt 2010) }\end{array}$ & $\begin{array}{l}\text { Cerebral palsy in } \\
\text { surviving children } \\
\text { available for fol- } \\
\text { low-up at } 2 \text { years } \\
\text { up to } 3.5 \text { to } 4.2 \\
\text { years (only cere- } \\
\text { bral palsy signif- } \\
\text { icant enough to } \\
\text { cause moderate } \\
\text { or severe impair- } \\
\text { ment was includ- } \\
\text { ed) }\end{array}$ & $\begin{array}{l}78 \text { per } 1000 \\
(21 / 270)\end{array}$ & $\begin{array}{l}88 \text { per } 1000 \\
(50 \text { to } 156)\end{array}$ & $\begin{array}{l}\text { RR } 1.13(0.64 \\
\text { to } 2.00)\end{array}$ & 532 (3 RCTs) & MODERATE & $\begin{array}{l}\text { Imprecision }(-1) \text { : wide } \mathrm{Cl} \text { crossing } \\
\text { line of no effect }\end{array}$ \\
\hline
\end{tabular}




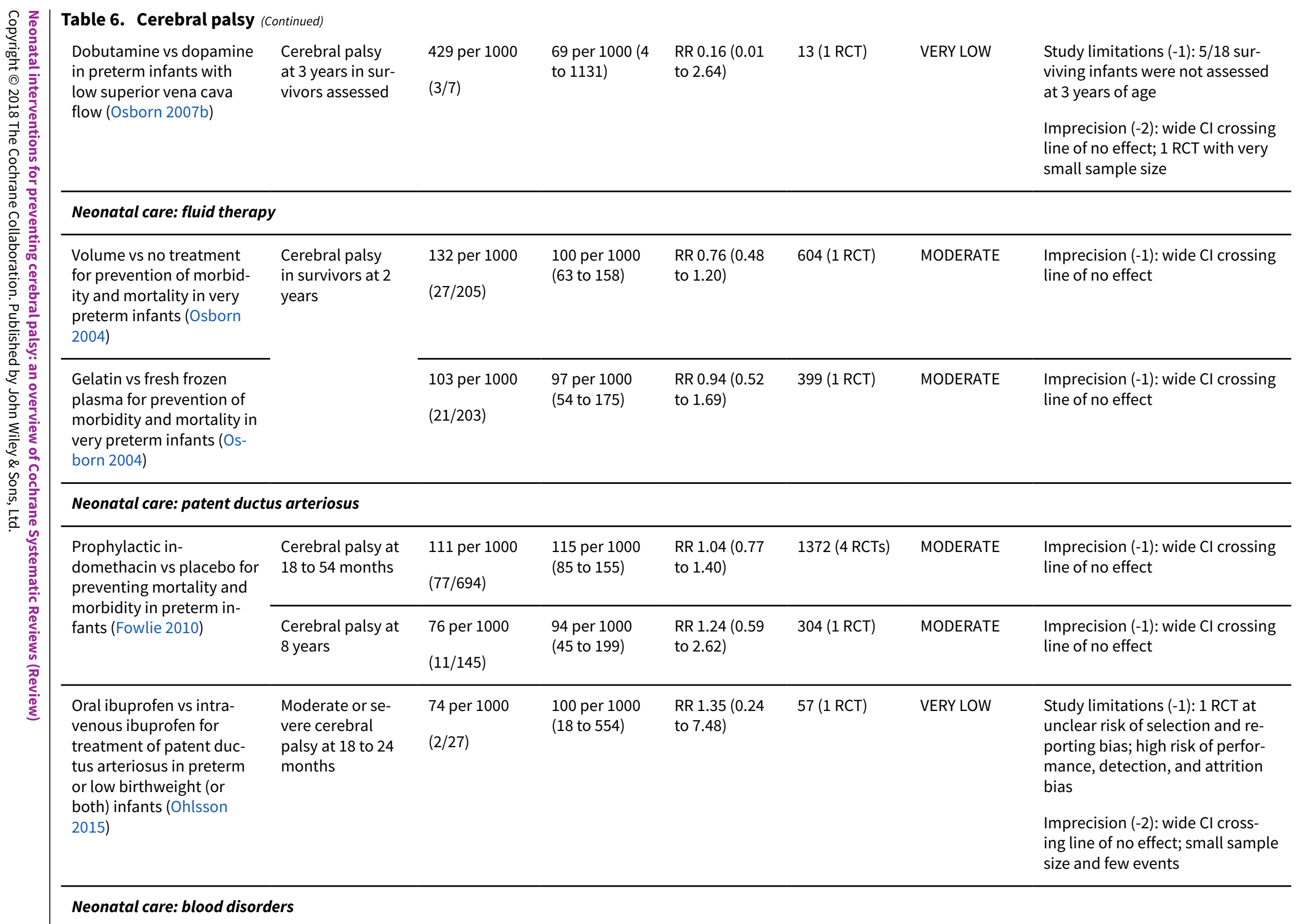




\begin{tabular}{|c|c|c|c|c|c|c|c|}
\hline $\begin{array}{l}\text { Erythropoietin vs placebo } \\
\text { for preventing red blood } \\
\text { cell transfusion in preterm } \\
\text { and/or low birthweight in- } \\
\text { fants (Ohlsson 2014) }\end{array}$ & $\begin{array}{l}\text { Cerebral palsy at } \\
18 \text { to } 22 \text { months' } \\
\text { corrected age (in } \\
\text { children exam- } \\
\text { ined) }\end{array}$ & $\begin{array}{l}187 \text { per } 1000 \\
(14 / 75)\end{array}$ & $\begin{array}{l}123 \text { per } 1000 \\
(58 \text { to } 256)\end{array}$ & $\begin{array}{l}\text { RR } 0.66(0.31 \\
\text { to } 1.37)\end{array}$ & 153 (2 RCTs) & VERY LOW & $\begin{array}{l}\text { Study limitations (-1): } 1 \text { RCT at } \\
\text { unclear risk of selection bias and } \\
\text { high risk of attrition bias ( } 73 \% \\
\text { follow-up) } \\
\text { Inconsistency }(-1): I^{2}=72 \% \\
\text { Imprecision (-2): wide } \mathrm{Cl} \text { cross- } \\
\text { ing line of no effect; small sample } \\
\text { sizes }\end{array}$ \\
\hline $\begin{array}{l}\text { Darbepoetin alfa vs place- } \\
\text { bo for preventing red } \\
\text { blood cell transfusion in } \\
\text { preterm and/or low birth- } \\
\text { weight infants (Ohlsson } \\
\text { 2014) }\end{array}$ & & $\begin{array}{l}208 \text { per } 1000 \\
(5 / 24)\end{array}$ & $\begin{array}{l}17 \text { per } 1000(0 \\
\text { to } 292)\end{array}$ & $\begin{array}{l}\text { RR } 0.08(0.00 \\
\text { to } 1.40)\end{array}$ & $51(1 \mathrm{RCT})$ & LOW & $\begin{array}{l}\text { Imprecision (-2): wide } \mathrm{Cl} \text { crossing } \\
\text { line of no effect; } 1 \mathrm{RCT} \text { with small } \\
\text { sample size and few events }\end{array}$ \\
\hline $\begin{array}{l}\text { Transfusion at a restrictive } \\
\text { vs a liberal haemoglobin } \\
\text { threshold for preventing } \\
\text { morbidity and mortality } \\
\text { in very low birthweight in- } \\
\text { fants (Whyte 2011) }\end{array}$ & $\begin{array}{l}\text { Cerebral palsy at } \\
18 \text { to } 21 \text { months' } \\
\text { follow-up among } \\
\text { survivors }\end{array}$ & $\begin{array}{l}52 \text { per } 1000 \\
(9 / 172)\end{array}$ & $\begin{array}{l}68 \text { per } 1000 \\
(29 \text { to } 159)\end{array}$ & $\begin{array}{l}\mathrm{RR} 1.29(0.55 \\
\text { to } 3.03)\end{array}$ & 335 (1 RCT) & LOW & $\begin{array}{l}\text { Study limitations (-1): } 1 \text { RCT at } \\
\text { high risk of performance bias and } \\
\text { unclear risk of reporting bias } \\
\text { Imprecision (-1): wide } \mathrm{Cl} \text { crossing } \\
\text { line of no effect }\end{array}$ \\
\hline \multicolumn{8}{|c|}{ Neonatal care: pulmonary hypertension } \\
\hline $\begin{array}{l}\text { Endothelin receptor an- } \\
\text { tagonists vs placebo for } \\
\text { persistent pulmonary hy- } \\
\text { pertension in term and } \\
\text { late preterm infants (More } \\
\text { 2016) }\end{array}$ & $\begin{array}{l}\text { Cerebral palsy } \\
\text { at } 6 \text { months (de- } \\
\text { layed motor de- } \\
\text { velopment and } \\
\text { spasticity) }\end{array}$ & $\begin{array}{l}214 \text { per } 1000 \\
(3 / 14)\end{array}$ & $\begin{array}{l}19 \text { per } 1000(0 \\
\text { to } 345)\end{array}$ & $\begin{array}{l}\text { RR } 0.09(0.00 \\
\text { to } 1.61)\end{array}$ & $37(1 \mathrm{RCT})$ & LOW & $\begin{array}{l}\text { Study limitation (-1): } 8 / 23 \text { infants } \\
\text { in the placebo group were ex- } \\
\text { cluded from analysis } \\
\text { Imprecision (-1): } 1 \text { RCT; small } \\
\text { sample size } \\
\text { (GRADED by review authors them- } \\
\text { selves) }\end{array}$ \\
\hline \multicolumn{8}{|l|}{ Neonatal care: resuscitation } \\
\hline $\begin{array}{l}\text { Room air vs } 100 \% \text { oxygen } \\
\text { for resuscitation of infants } \\
\text { at birth (Tan 2005) }\end{array}$ & $\begin{array}{l}\text { Cerebral palsy in } \\
\text { those followed } \\
\text { up at } 18 \text { to } 24 \\
\text { months }\end{array}$ & $\begin{array}{l}74 \text { per } 1000 \\
(9 / 122)\end{array}$ & $\begin{array}{l}99 \text { per } 1000 \\
\text { (41 to } 239 \text { ) }\end{array}$ & $\begin{array}{l}\mathrm{RR} 1.34(0.55 \\
\text { to } 3.24)\end{array}$ & $213(1 \mathrm{RCT})$ & VERY LOW & $\begin{array}{l}\text { Study limitations (-2): } 1 \text { qRCT } \\
\text { with no blinding and }<70 \% \text { fol- } \\
\text { low-up } \\
\text { Imprecision (-1): wide } \mathrm{Cl} \text { crossing } \\
\text { line of no effect }\end{array}$ \\
\hline
\end{tabular}




\begin{tabular}{|c|c|c|c|c|c|c|c|}
\hline \multicolumn{8}{|c|}{ Neonatal care: nitric oxide } \\
\hline $\begin{array}{l}\text { Inhaled NO vs placebo } \\
\text { for respiratory failure in } \\
\text { preterm infants (entry } \\
\text { before } 3 \text { days based on } \\
\text { oxygenation) (Barrington } \\
\text { 2010) }\end{array}$ & $\begin{array}{l}\text { Cerebral palsy at } \\
18 \text { to } 22 \text { months } \\
\text { (moderate/se- } \\
\text { vere or disabling) }\end{array}$ & $\begin{array}{l}100 \text { per } 1000 \\
(11 / 110)\end{array}$ & $\begin{array}{l}185 \text { per } 1000 \\
(93 \text { to } 371 \text { ) }\end{array}$ & $\begin{array}{l}\mathrm{RR} 1.85(0.93 \\
\text { to } 3.71)\end{array}$ & 209 (2 RCTs) & LOW & $\begin{array}{l}\text { Imprecision (-2): wide } \mathrm{Cl} \text { cross- } \\
\text { ing line of no effect; small sample } \\
\text { sizes }\end{array}$ \\
\hline $\begin{array}{l}\text { Inhaled NO vs placebo or } \\
\text { no treatment for respira- } \\
\text { tory failure in preterm in- } \\
\text { fants (entry after } 3 \text { days } \\
\text { based on BPD risk) (Bar- } \\
\text { rington 2010) }\end{array}$ & $\begin{array}{l}\text { Cerebral palsy at } \\
2 \text { years' corrected } \\
\text { age or } 30 \text { months } \\
\text { (1 RCT all severi- } \\
\text { ties; } 1 \text { RCT mod- } \\
\text { erate/severe or } \\
\text { disabling) }\end{array}$ & $\begin{array}{l}56 \text { per } 1000 \\
(14 / 248)\end{array}$ & $\begin{array}{l}62 \text { per } 1000 \\
(30 \text { to } 126)\end{array}$ & $\begin{array}{l}\mathrm{RR} 1.10(0.54 \\
\text { to } 2.23)\end{array}$ & 498 (2 RCTs) & LOW & $\begin{array}{l}\text { Study limitations (-1): } 1 \text { RCT with } \\
\text { no blinding of intervention or } \\
\text { outcome measurement } \\
\text { Imprecision (-1): wide Cl cross- } \\
\text { ing line of no effect; small sample } \\
\text { sizes }\end{array}$ \\
\hline $\begin{array}{l}\text { Inhaled NO vs placebo } \\
\text { for respiratory failure in } \\
\text { preterm infants (studies of } \\
\text { routine use in intubated } \\
\text { preterm infants) (Barring- } \\
\text { ton 2010) }\end{array}$ & $\begin{array}{l}\text { Cerebral palsy } \\
\text { at } 1 \text { or } 2 \text { years' } \\
\text { corrected age (1 } \\
\text { RCT all severi- } \\
\text { ties; } 1 \text { RCT mod- } \\
\text { erate/severe or } \\
\text { disabling) }\end{array}$ & $\begin{array}{l}70 \text { per } 1000 \\
(20 / 286)\end{array}$ & $\begin{array}{l}66 \text { per } 1000 \\
(36 \text { to } 119)\end{array}$ & $\begin{array}{l}\text { RR } 0.94(0.51 \\
\text { to } 1.70)\end{array}$ & 593 (2 RCTs) & LOW & $\begin{array}{l}\text { Study limitations (-1): } 2 \text { RCTs with } \\
74 \%-82 \% \text { follow-up } \\
\text { Imprecision (-1): wide } \mathrm{Cl} \text { crossing } \\
\text { line of no effect }\end{array}$ \\
\hline \multirow[t]{2}{*}{$\begin{array}{l}\text { Inhaled nitric oxide vs } \\
\text { placebo for respiratory } \\
\text { failure in infants born at or } \\
\text { near term (Finer 2006) }\end{array}$} & $\begin{array}{l}\text { Cerebral palsy } \\
\text { among survivors } \\
\text { at } 13 \text { or } 18 \text { to } 24 \\
\text { months }\end{array}$ & $\begin{array}{l}89 \text { per } 1000 \\
(16 / 179)\end{array}$ & $\begin{array}{l}91 \text { per } 1000 \\
(44 \text { to } 191)\end{array}$ & $\begin{array}{l}\text { RR } 1.02(0.49 \\
\text { to } 2.14)\end{array}$ & 299 (2 RCTs) & LOW & $\begin{array}{l}\text { Study limitations (-1): } 1 \text { RCT } \\
\text { masking of allocation, masking of } \\
\text { outcomes. and completeness of } \\
\text { follow-up } \\
\text { Imprecision (-1): wide } \mathrm{Cl} \text { crossing } \\
\text { line of no effect }\end{array}$ \\
\hline & \multicolumn{5}{|c|}{$\begin{array}{l}\text { "This group has now published follow up data, including neurodevelopmental out- } \\
\text { comes, which were obtained by telephone interview of } 60 \text { of the } 83 \text { survivors of the orig- } \\
\text { inal trial. The interview was conducted between one and four years of age... Although } \\
\text { cerebral palsy [was] reported it is unclear how [it] was defined... It is not, therefore, pos- } \\
\text { sible to add any of these data to the meta-analysis, but they do appear to show no evi- } \\
\text { dence of neurodevelopmental impairment due to inhaled nitric oxide therapy" }\end{array}$} & NOT GRADED & \\
\hline $\begin{array}{l}\text { Inhaled nitric oxide vs } \\
\text { placebo for respirato- } \\
\text { ry failure in infants with } \\
\text { diaphragmatic hernias }\end{array}$ & $\begin{array}{l}\text { Cerebral pal- } \\
\text { sy among sur- } \\
\text { vivors at } 18 \text { to } 24 \\
\text { months }\end{array}$ & $(0 / 14)$ & $(2 / 8)$ & $\begin{array}{l}\text { RR } 8.33(0.45 \\
\text { to } 154.78)\end{array}$ & 22 (1 RCT) & VERY LOW & $\begin{array}{l}\text { Study limitations (-1): } 1 \text { RCT with } \\
76 \% \text { follow-up of survivors } \\
\text { Imprecision (-2): wide CI crossing } \\
\text { line of no effect; } 1 \text { small RCT }\end{array}$ \\
\hline
\end{tabular}




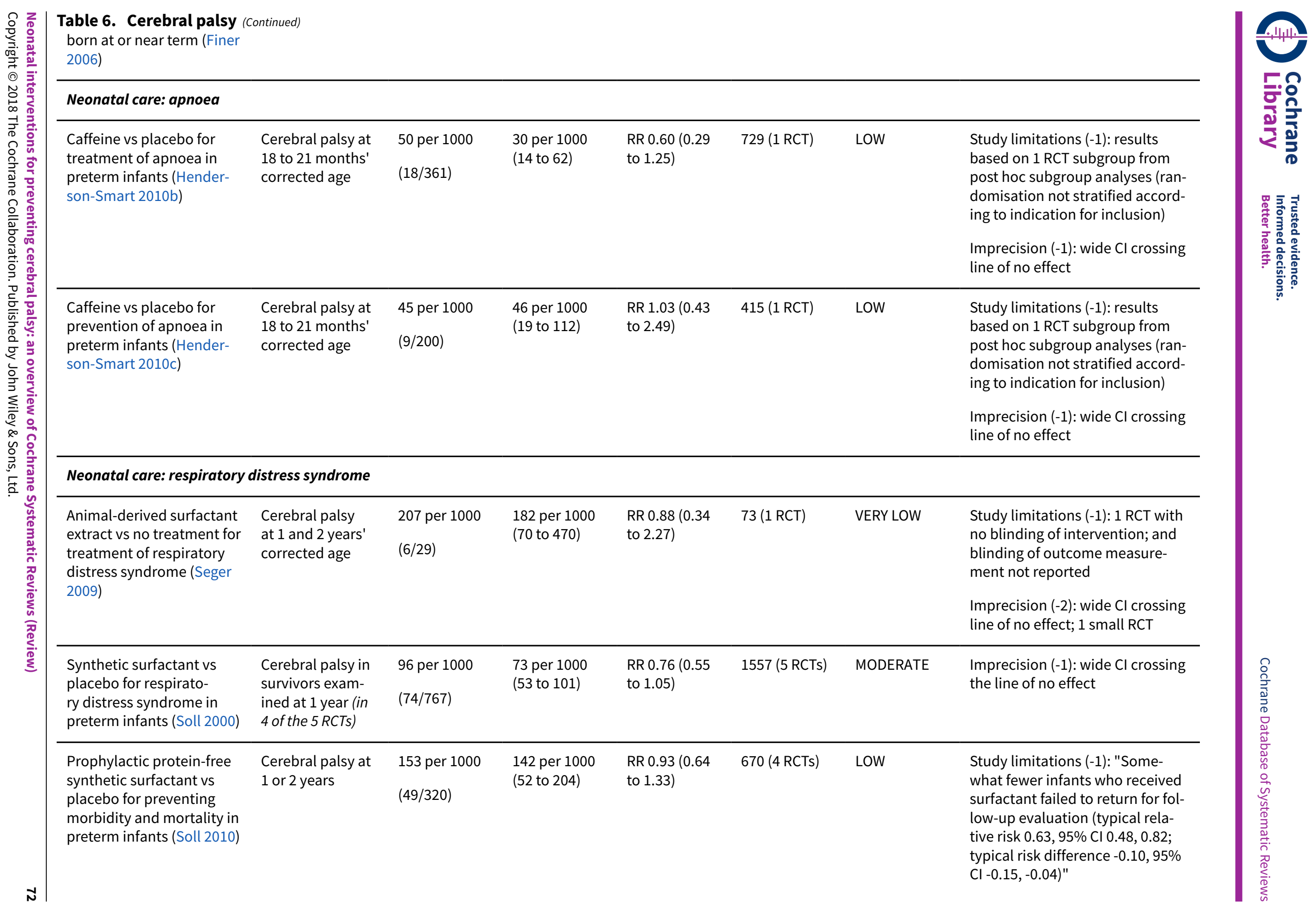




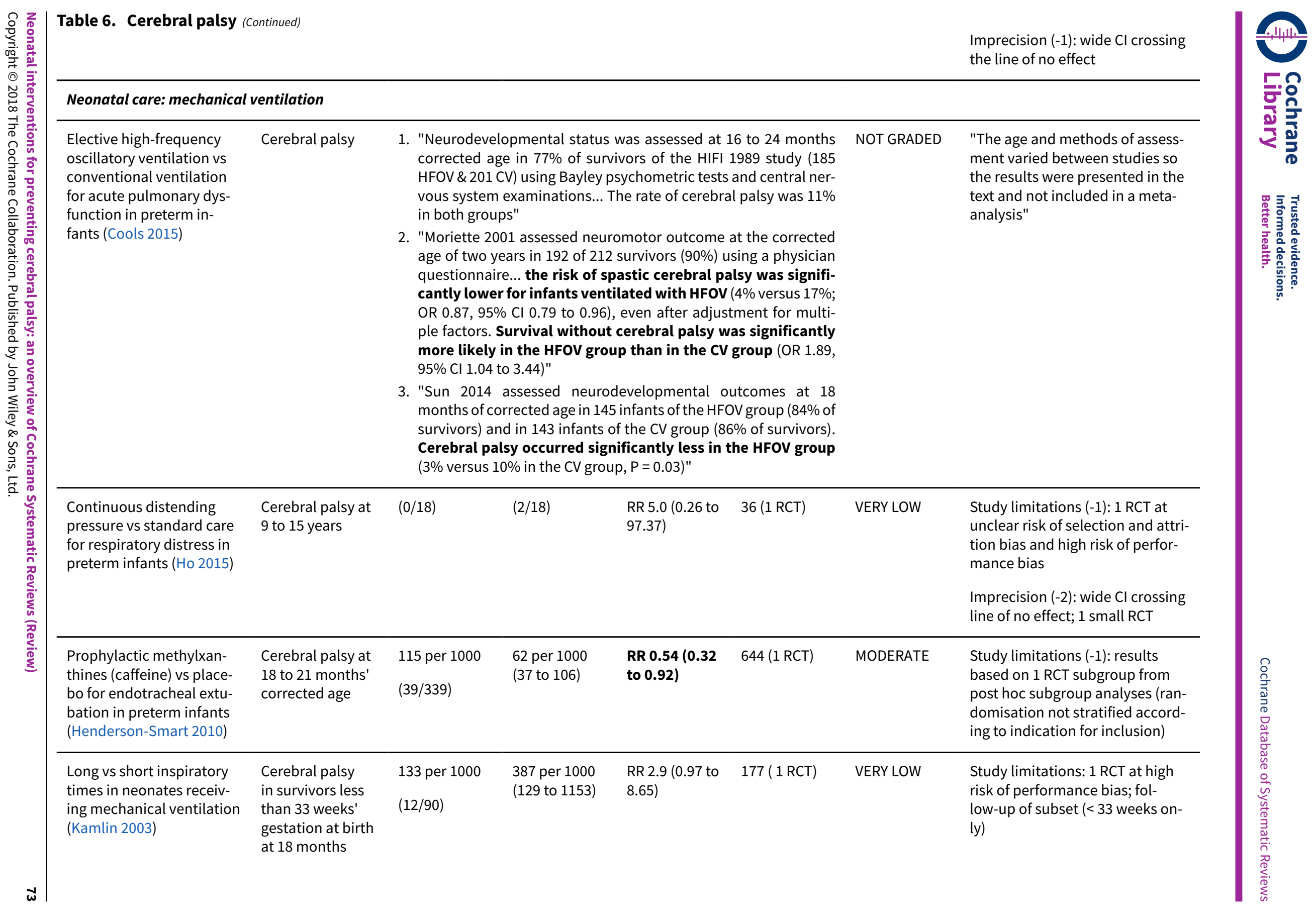




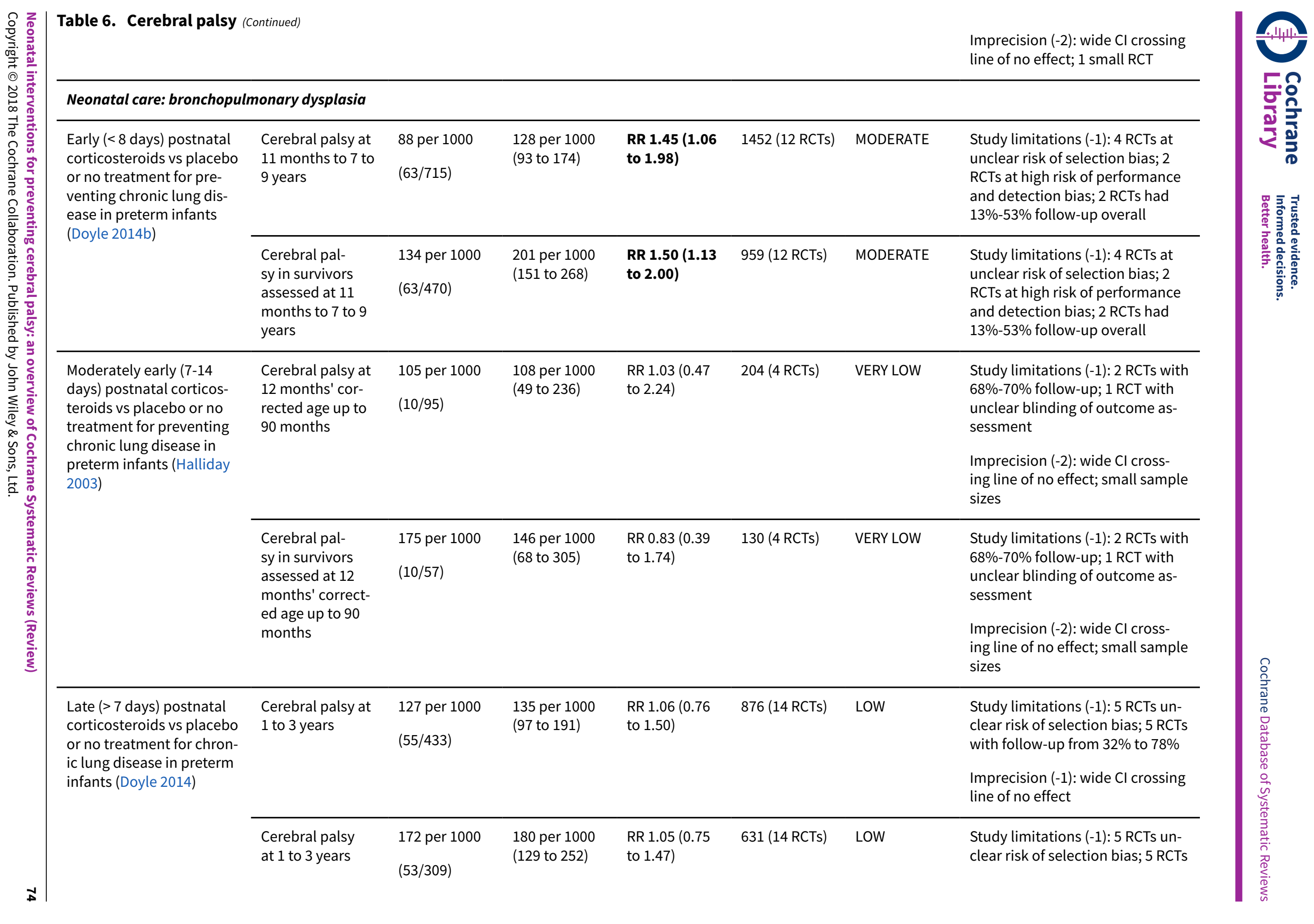




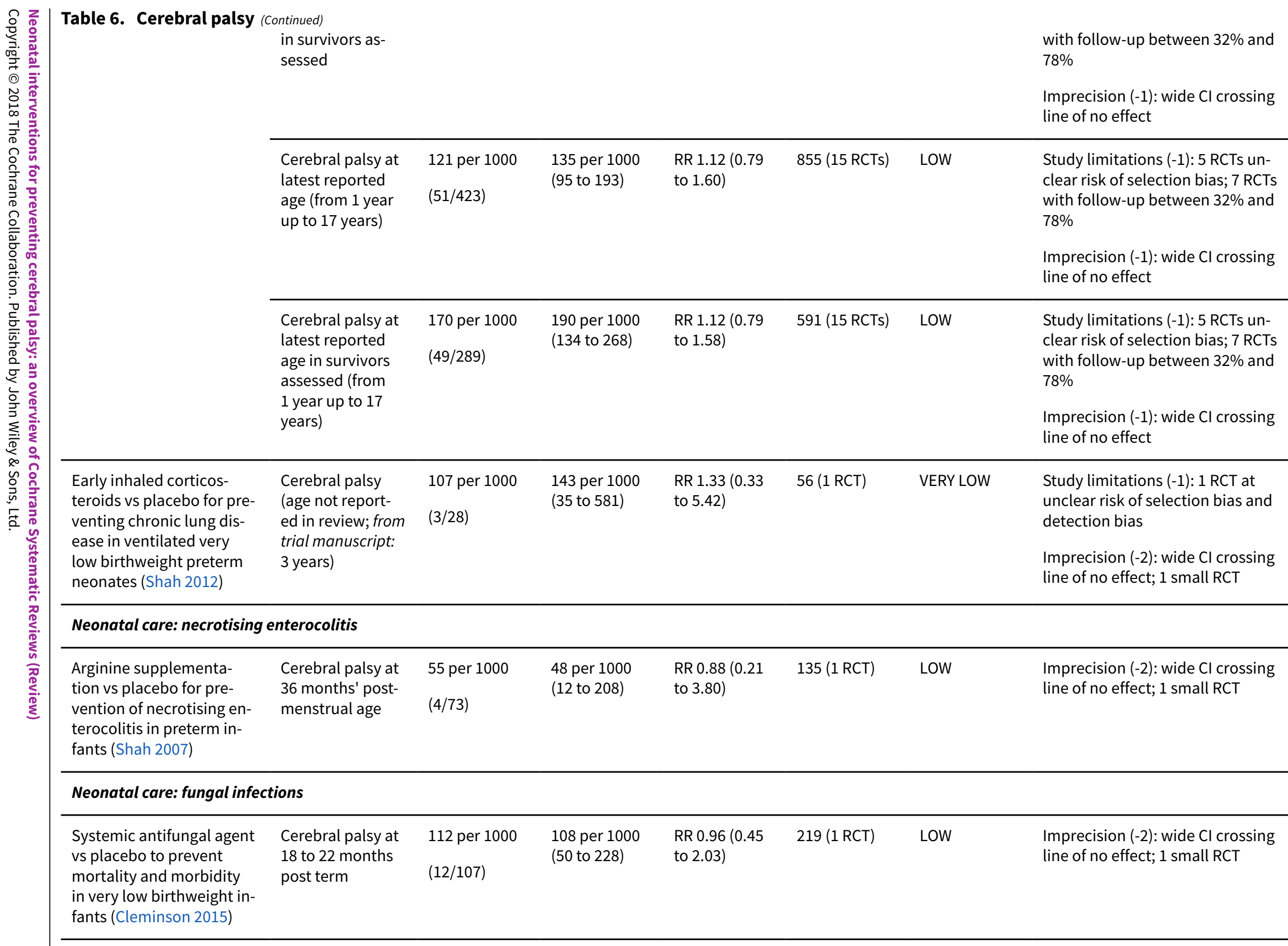




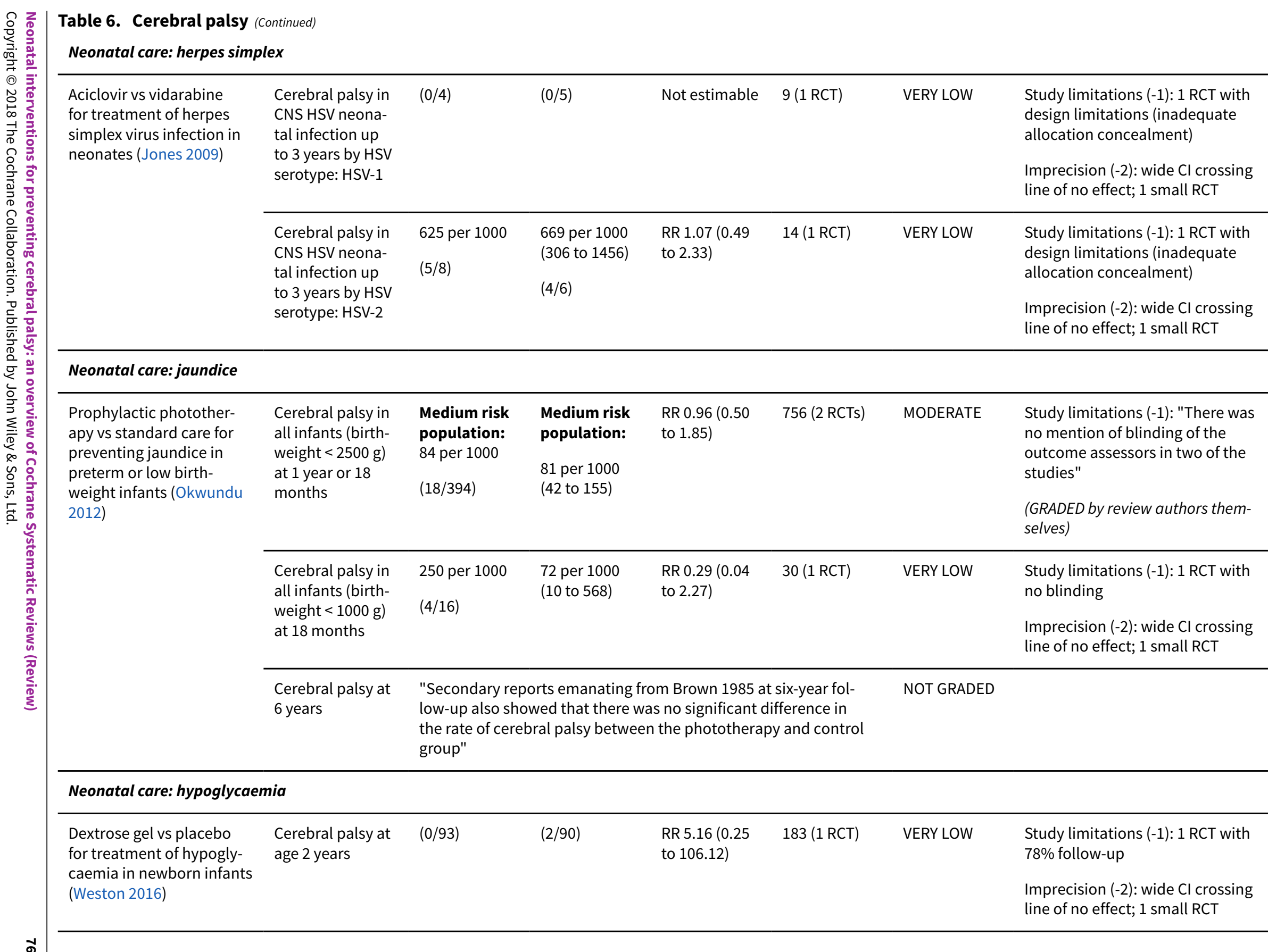




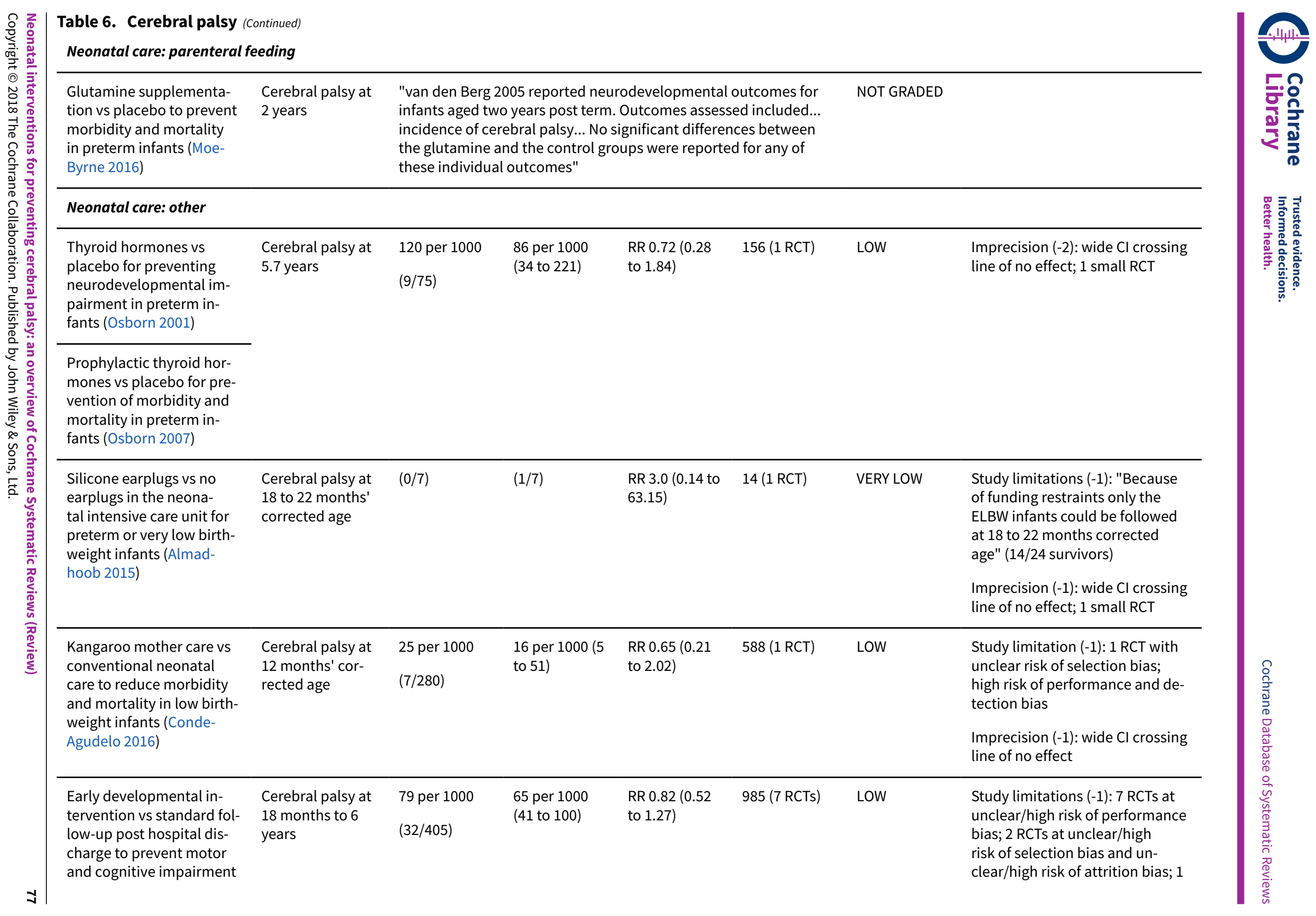




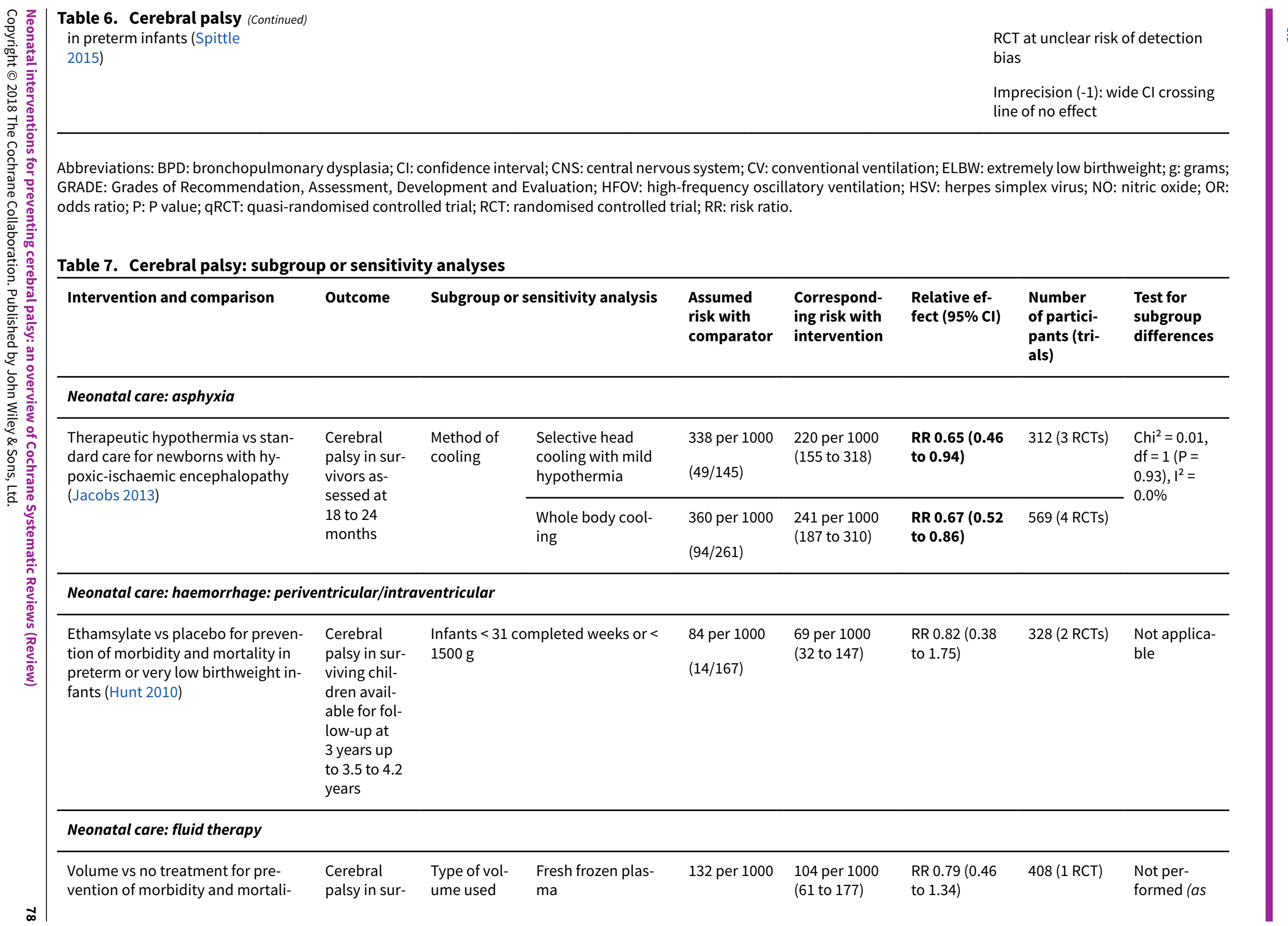




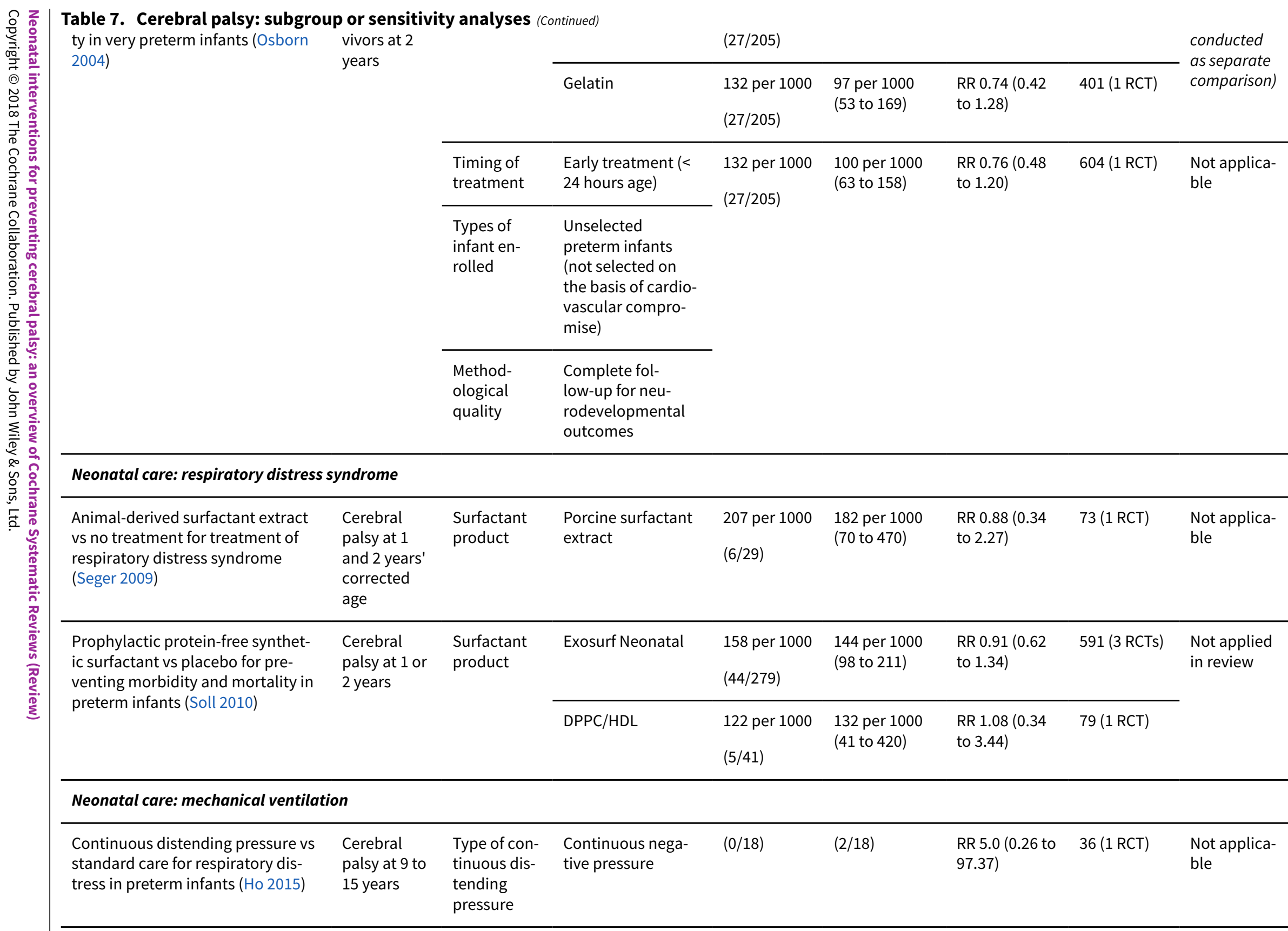




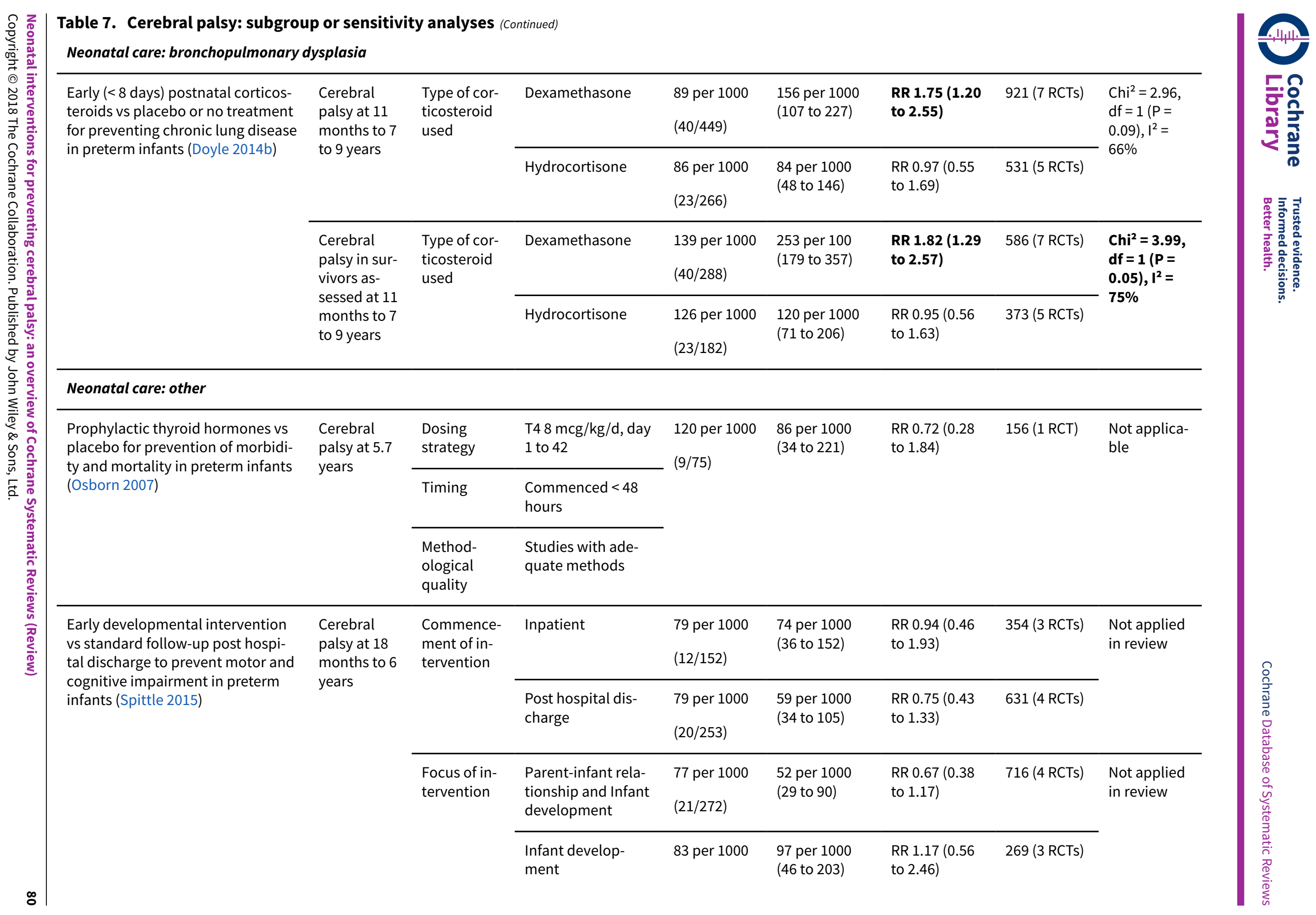




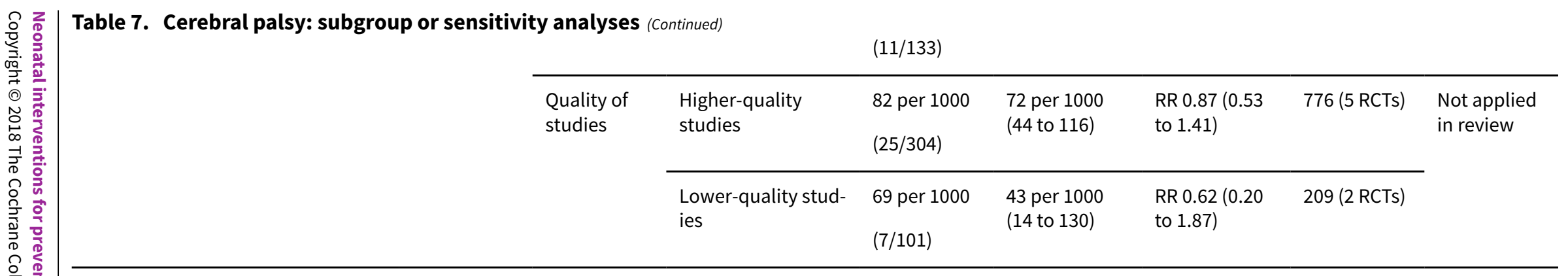

Abbreviations: Cl: confidence interval; DPPC/HDL: dipalmitoylphosphatidylcholine/high-density lipoprotein; g: grams; P: P value; RCT: randomised controlled trial; RR: risk ratio; T4: thyroxine.

\section{Table 8. Cerebral palsy or death}

\begin{tabular}{|c|c|c|c|c|c|c|c|}
\hline $\begin{array}{l}\text { Intervention and compari- } \\
\text { son }\end{array}$ & Outcome & $\begin{array}{l}\text { Assumed risk } \\
\text { with com- } \\
\text { parator }\end{array}$ & $\begin{array}{l}\text { Correspond- } \\
\text { ing risk with } \\
\text { intervention }\end{array}$ & $\begin{array}{l}\text { Relative ef- } \\
\text { fect }(95 \% \mathrm{Cl})\end{array}$ & $\begin{array}{l}\text { Number of } \\
\text { participants } \\
\text { (trials) }\end{array}$ & $\begin{array}{l}\text { Quality of } \\
\text { the evidence } \\
\text { (GRADE) }\end{array}$ & Comments \\
\hline
\end{tabular}

Neonatal care: bronchopulmonary dysplasia

Early (<8 days) postnatal cor- Cerebral palsy

ticosteroids vs placebo or

or death at 11

352 per 1000

months to $7 \quad(252 / 715)$

RR 1.09 (0.95

1452 (12 RCTs) MODERATE

Study limitations (-1): 4 RCTs at

unclear risk of selection bias; 2

RCTs at high risk of performance

and detection bias; 2 RCTs had

ing chronic lung disease in to 9 years

preterm infants (Doyle 2014b)

Moderately early (7-14 days) postnatal corticosteroids vs

placebo or no treatment for

Cerebral palsy

or death at 12

months' cor-

316 per 1000

262 per 1000

$13 \%$ to $53 \%$ follow-up overall

preventing chronic lung dis-

rected age up

ease in preterm infants (Halli- to 90 months

(30/95)

(174 to 388) to 1.23 )

Study limitations (-1): 2 RCTs with $68 \%$ to $70 \%$ follow-up; 1 RCT with

unclear blinding of outcome as-

sessment

day 2003)

Imprecision (-2): wide $\mathrm{Cl}$ cross-

ing line of no effect; small sample sizes

Late (> 7 days) postnatal cor-

ticosteroids vs placebo or no

Cerebral palsy

328 per 1000

302 per 1000

RR $0.92(0.76$

876 (14 RCTs)

LOW

Study limitations (-1): 5 RCTs un-

or death at 1

(142/433)

(249 to 367 ) to 1.12 )

clear risk of selection bias; 5 RCTs

treatment for chronic lung
disease in preterm infants

to 3 years

$(142 / 433)$

with follow-up between $32 \%$ and $78 \%$

(Doyle 2014)

Imprecision (-1): wide $\mathrm{Cl}$ crossing

line of no effect 


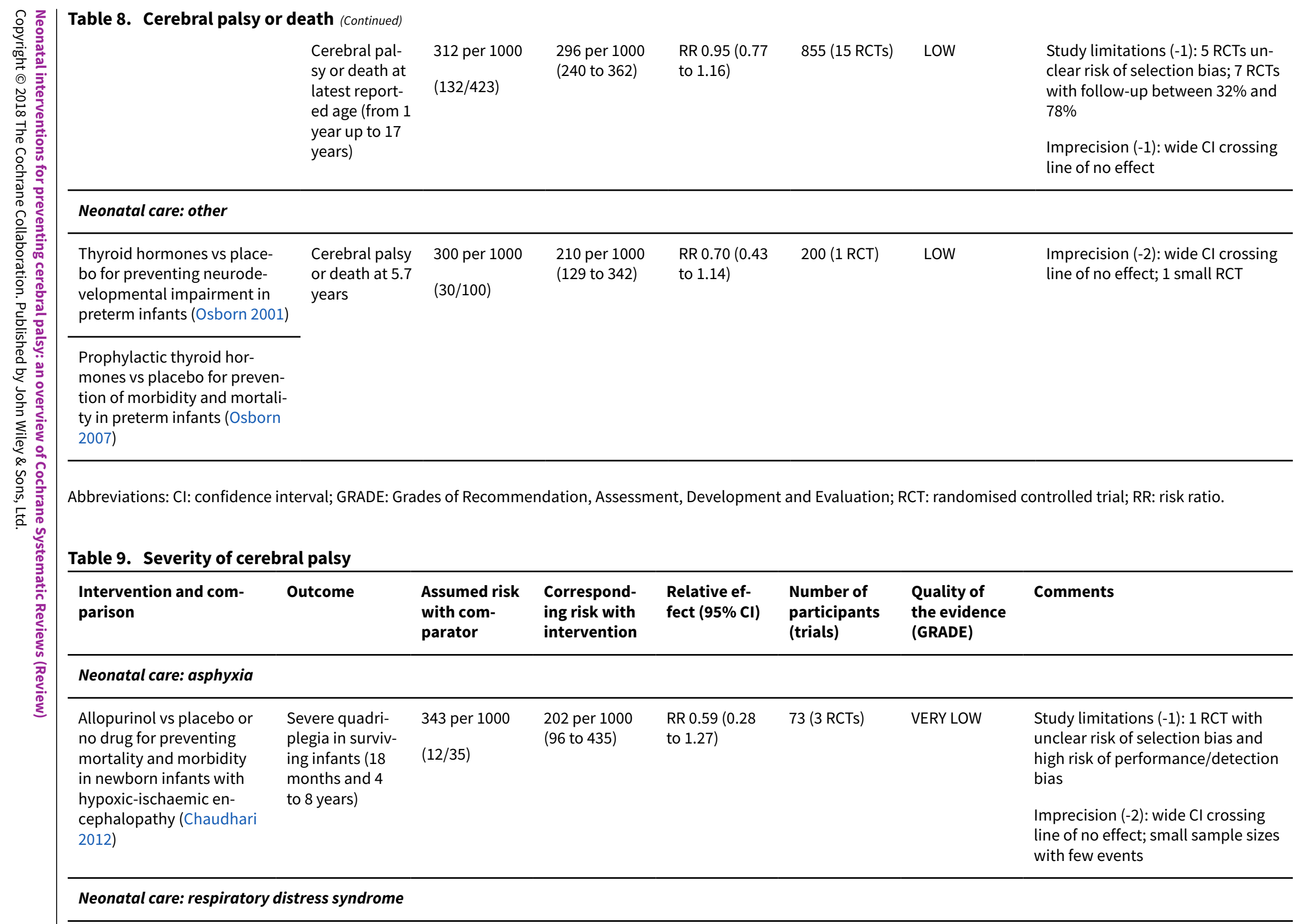




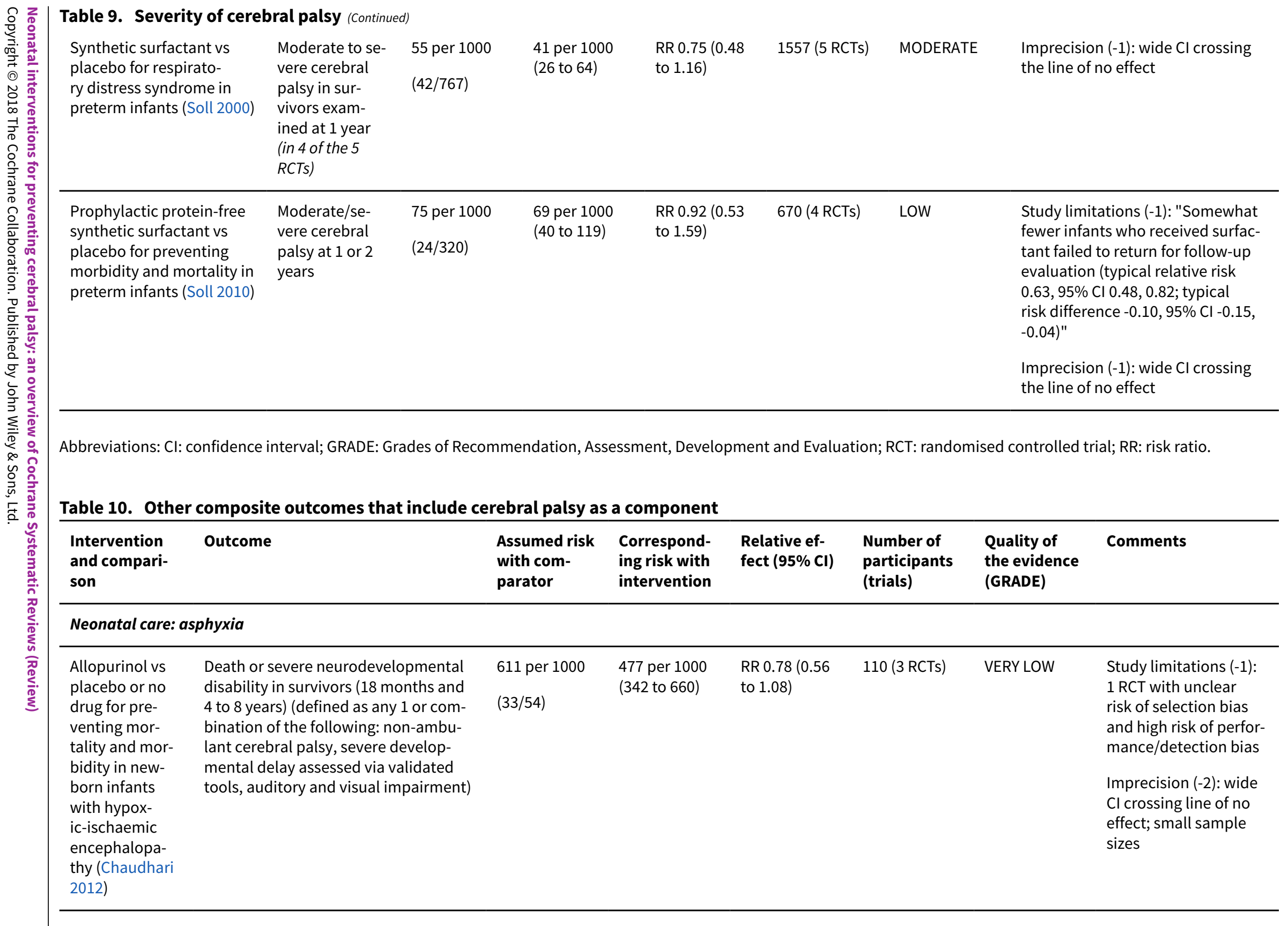




\begin{tabular}{|c|c|c|c|c|c|c|c|}
\hline \multirow[t]{5}{*}{$\begin{array}{l}\text { Therapeutic hy- } \\
\text { pothermia vs } \\
\text { standard care } \\
\text { for newborns } \\
\text { with hypoxic-is- } \\
\text { chaemic en- } \\
\text { cephalopathy } \\
\text { (Jacobs 2013) }\end{array}$} & $\begin{array}{l}\text { Death or major disability in survivors } \\
\text { assessed at } 18 \text { to } 24 \text { months (defined } \\
\text { as cerebral palsy, developmental de- } \\
\text { lay (BSID or GMDS assessment }>2 \\
\text { SD below the mean) or intellectual } \\
\text { impairment (IQ > } 2 \text { SD below mean), } \\
\text { blindness (vision }<6 / 60 \text { in both eyes), } \\
\text { sensorineural deafness requiring am- } \\
\text { plification) }\end{array}$ & $\begin{array}{l}614 \text { per } 1000 \\
(409 / 666)\end{array}$ & $\begin{array}{l}461 \text { per } 1000 \\
(418 \text { to } 510)\end{array}$ & $\begin{array}{l}\text { RR } 0.75(0.68 \\
\text { to } 0.83)\end{array}$ & 1344 (8 RCTs) & $\mathrm{HIGH}$ & Not downgraded \\
\hline & $\begin{array}{l}\text { Major neurodevelopmental disabili- } \\
\text { ty at } 18 \text { to } 24 \text { months (defined as cere- } \\
\text { bral palsy, developmental delay (BSID } \\
\text { or GMDS assessment }>2 \text { SD below the } \\
\text { mean) or intellectual impairment (IQ > } \\
2 \text { SD below mean), blindness (vision < } \\
6 / 60 \text { in both eyes), sensorineural deaf- } \\
\text { ness requiring amplification) }\end{array}$ & $\begin{array}{l}249 \text { per } 1000 \\
(166 / 666)\end{array}$ & $\begin{array}{l}192 \text { per } 1000 \\
(157 \text { to } 234)\end{array}$ & $\begin{array}{l}\text { RR } 0.77(0.63 \\
\text { to } 0.94)\end{array}$ & 1344 (8 RCTs) & $\mathrm{HIGH}$ & Not downgraded \\
\hline & $\begin{array}{l}\text { Major neurodevelopmental disabil- } \\
\text { ity in survivors assessed at } 18 \text { to } 24 \\
\text { months (defined as cerebral palsy, de- } \\
\text { velopmental delay (BSID or GMDS as- } \\
\text { sessment }>2 \text { SD below the mean) or } \\
\text { intellectual impairment (IQ > } 2 \text { SD be- } \\
\text { low mean), blindness (vision }<6 / 60 \text { in } \\
\text { both eyes), sensorineural deafness re- } \\
\text { quiring amplification) }\end{array}$ & $\begin{array}{l}393 \text { per } 1000 \\
(166 / 422)\end{array}$ & $\begin{array}{l}264 \text { per } 1000 \\
\text { (216 to } 315)\end{array}$ & $\begin{array}{l}\text { RR } 0.67(0.55 \\
\text { to } 0.80)\end{array}$ & 917 (8 RCTs) & $\mathrm{HIGH}$ & Not downgraded \\
\hline & $\begin{array}{l}\text { Death or moderate to severe disabil- } \\
\text { ity at } 6 \text { to } 7 \text { years (defined as IQ } \geq 2 \\
\text { SD below the mean, a GMF level of } 3 \\
\text { or greater, bilateral deafness (with or } \\
\text { without amplification), bilateral blind- } \\
\text { ness, or refractory epilepsy) }\end{array}$ & $\begin{array}{l}645 \text { per } 1000 \\
(60 / 93)\end{array}$ & $\begin{array}{l}523 \text { per } 1000 \\
\text { (413 to } 671 \text { ) }\end{array}$ & $\begin{array}{l}\text { RR } 0.81(0.64 \\
\text { to } 1.04)\end{array}$ & 190 (1 RCT) & LOW & $\begin{array}{l}\text { Imprecision (-2): wide } \\
\text { Cl crossing line of } \\
\text { no effect; } 1 \text { RCT with } \\
\text { small sample size }\end{array}$ \\
\hline & $\begin{array}{l}\text { Moderate-to-severe disability at } 6 \text { to } 7 \\
\text { years (defined as IQ } \geq 2 \text { SD below the } \\
\text { mean, a GMF level of } 3 \text { or greater, bilat- } \\
\text { eral deafness (with or without amplifi- } \\
\text { cation), bilateral blindness or refracto- } \\
\text { ry epilepsy) }\end{array}$ & $\begin{array}{l}380 \text { per } 1000 \\
(19 / 50)\end{array}$ & $\begin{array}{l}350 \text { per } 1000 \\
\text { ( } 217 \text { to } 562 \text { ) }\end{array}$ & $\begin{array}{l}\text { RR } 0.92(0.57 \\
\text { to } 1.48)\end{array}$ & 119 (1 RCT) & LOW & $\begin{array}{l}\text { Imprecision (-2): wide } \\
\mathrm{Cl} \text { crossing line of } \\
\text { no effect; } 1 \text { RCT with } \\
\text { small sample size }\end{array}$ \\
\hline
\end{tabular}


tudy limitations (-1): (derined as cerebral palsy, developmental delay (BSID or GMDS assessment $>2$ SD below the mean) or bidity and mor- intellectual impairment (IQ $>2$ SD beintellectual impairment (IQ $>2$ SD be-
low mean), blindness (vision $<6 / 60$ in phyxia (Young requiring amplification) 2016) follow-up: > 12 months ( 3 years) (defined as cerebral palsy, developmental delay (BSID or GMDS assessment > $2 \mathrm{SD}$ below the mean) or intellectual impairment (IQ > 2 SD below mean), blindness (vision < 6/60 in both eyes), or sensorineural deafness requiring amplification

$\begin{array}{lllll}563 \text { per } 1000 & \begin{array}{l}135 \text { per } 1000 \\ \text { (34 to } 518)\end{array} & \begin{array}{l}\text { RR } 0.24 \\ (\mathbf{0 . 0 6} \text { to } \mathbf{0 . 9 2})\end{array} & 31(1 \mathrm{RCT}) & \text { VERY LOW } \\ (9 / 16) & & & \end{array}$

cern regarding performance bias, detection

bias, and incomplete follow-up

Imprecision (-2): 95\% Cls were wide and imprecise

(graded by review authors themselves)

Study limitations (-1): unblinded study; concern regarding performance bias, detection bias, and incomplete follow-up

Imprecision (-2): 95\% $\mathrm{Cls}$ were wide and imprecise

(graded by review authors themselves)

Neonatal care: haemorrhage: periventricular/intraventricular

\begin{tabular}{|c|c|c|c|c|c|c|c|}
\hline \multirow[t]{2}{*}{$\begin{array}{l}\text { Ethamsylate } \\
\text { vs placebo for } \\
\text { prevention of } \\
\text { morbidity and } \\
\text { mortality in } \\
\text { preterm or very } \\
\text { low birthweight } \\
\text { infants (Hunt } \\
\text { 2010) }\end{array}$} & $\begin{array}{l}\text { Neurodevelopmental disability at } 2 \\
\text { years of age in surviving children avail- } \\
\text { able for follow-up (defined as cerebral } \\
\text { palsy on clinical examination, devel- } \\
\text { opmental delay }>2 \text { SD below popula- } \\
\text { tion mean on any standard test of de- } \\
\text { velopment, or blindness (VA }<6 / 60 \text { ), or } \\
\text { deafness (any hearing impairment re- } \\
\text { quiring amplification) at any time after } \\
2 \text { years' corrected age) }\end{array}$ & $\begin{array}{l}170 \text { per } 1000 \\
(46 / 270)\end{array}$ & $\begin{array}{l}135 \text { per } 1000 \\
\text { (90 to } 199)\end{array}$ & $\begin{array}{l}\text { RR } 0.79(0.53 \\
\text { to } 1.17)\end{array}$ & 532 (3 RCTs) & MODERATE & $\begin{array}{l}\text { Imprecision (-1): wide } \\
\mathrm{Cl} \text { crossing line of no } \\
\text { effect }\end{array}$ \\
\hline & $\begin{array}{l}\text { Death or any disability by } 2 \text { years of } \\
\text { age in children with known outcome } \\
\text { at any point in time (not defined in re- } \\
\text { view) }\end{array}$ & $\begin{array}{l}338 \text { per } 1000 \\
(233 / 690)\end{array}$ & $\begin{array}{l}324 \text { per } 1000 \\
(277 \text { to } 375)\end{array}$ & $\begin{array}{l}\text { RR } 0.96(0.82 \\
\text { to } 1.11)\end{array}$ & 1334 (7 RCTs) & LOW & $\begin{array}{l}\text { Study limitations }(-1) \text { : } \\
4 \text { RCTs at unclear risk } \\
\text { of selection bias; } 3 \\
\text { RCTs at unclear risk }\end{array}$ \\
\hline
\end{tabular}




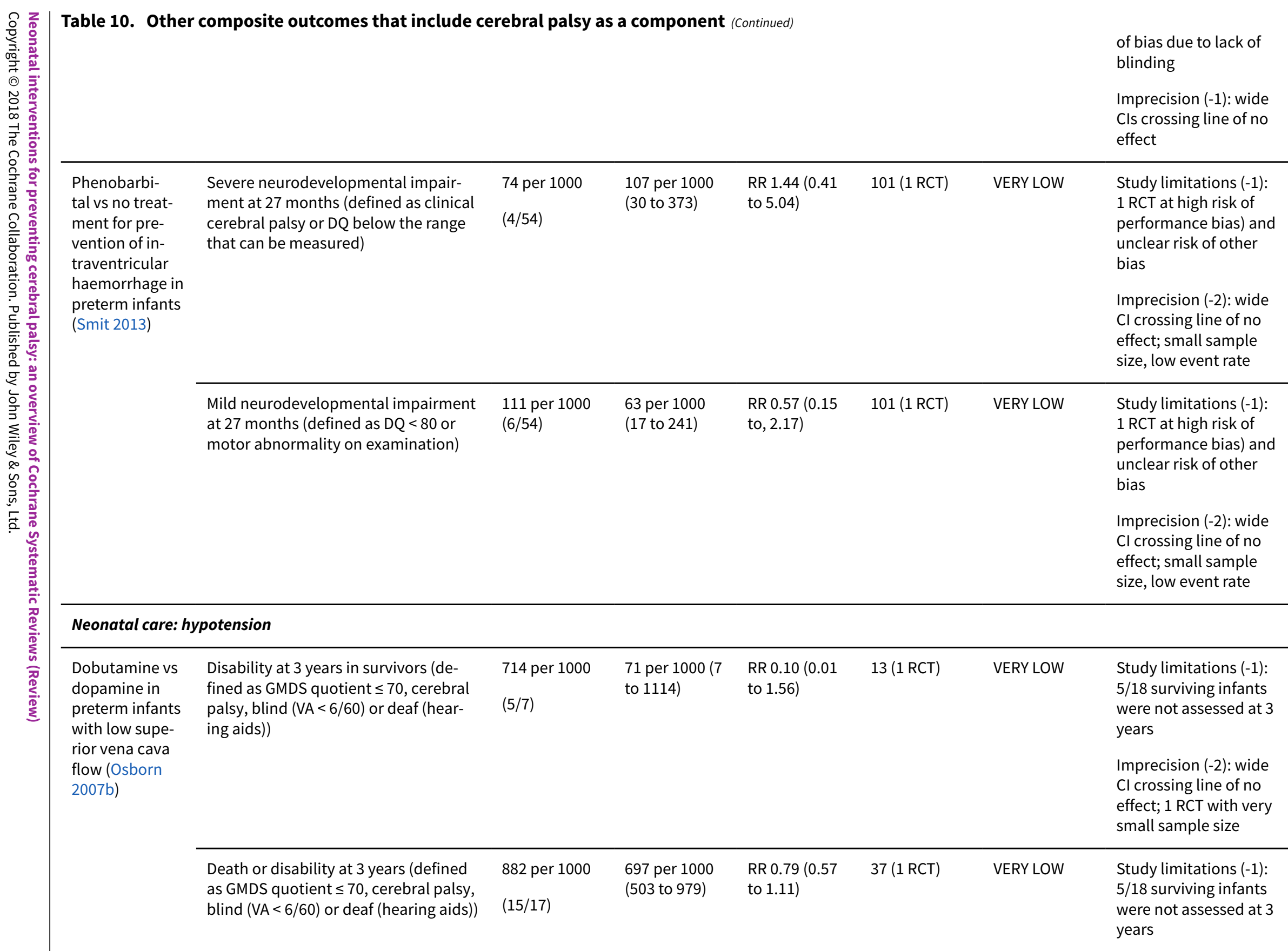




\begin{tabular}{|c|c|c|c|c|c|c|c|}
\hline & & & & & & & $\begin{array}{l}\text { Imprecision (-2): wide } \\
\text { Cl crossing line of no } \\
\text { effect; } 1 \text { RCT with very } \\
\text { small sample size }\end{array}$ \\
\hline & $\begin{array}{l}\text { Death or disability at latest follow-up } \\
\text { ( } 1 \text { to } 3 \text { years) (defined as GMDS quo- } \\
\text { tient } \leq 70 \text {, cerebral palsy, blind (VA< } \\
6 / 60 \text { ) or deaf (hearing aids)) }\end{array}$ & $\begin{array}{l}750 \text { per } 1000 \\
(15 / 20)\end{array}$ & $\begin{array}{l}713 \text { per } 1000 \\
\text { (495 to } 1035)\end{array}$ & $\begin{array}{l}\text { RR } 0.95(0.66 \\
\text { to } 1.38)\end{array}$ & $41(1 \mathrm{RCT})$ & VERY LOW & $\begin{array}{l}\text { Study limitations (-1): } \\
5 / 18 \text { surviving infants } \\
\text { were not assessed at } 3 \\
\text { years } \\
\text { Imprecision (-2): wide } \\
\text { Cl crossing line of no } \\
\text { effect; } 1 \text { RCT with very } \\
\text { small sample size }\end{array}$ \\
\hline \multicolumn{8}{|c|}{ Neonatal care: fluid therapy } \\
\hline $\begin{array}{l}\text { Volume vs no } \\
\text { treatment for } \\
\text { prevention of } \\
\text { morbidity and } \\
\text { mortality in } \\
\text { very preterm in- } \\
\text { fants (Osborn } \\
\text { 2004) }\end{array}$ & $\begin{array}{l}\text { Severe neurodevelopmental disabil- } \\
\text { ity in survivors at } 2 \text { years (defined as } \\
\text { blind, dead, unable to walk, DQ > } 3 \text { SD } \\
\text { below the mean, or another severe } \\
\text { disability) }\end{array}$ & $\begin{array}{l}141 \text { per } 1000 \\
(29 / 205)\end{array}$ & $\begin{array}{l}113 \text { per } 1000 \\
\text { (74 to } 174)\end{array}$ & $\begin{array}{l}\text { RR } 0.80(0.52 \\
\text { to } 1.23)\end{array}$ & $604(1 \mathrm{RCT})$ & MODERATE & $\begin{array}{l}\text { Imprecision (-1): wide } \\
\text { Cl crossing line of no } \\
\text { effect }\end{array}$ \\
\hline $\begin{array}{l}\text { Gelatin vs fresh } \\
\text { frozen plasma } \\
\text { for prevention } \\
\text { of morbidity } \\
\text { and mortality } \\
\text { in very preterm } \\
\text { infants (Osborn } \\
\text { 2004) }\end{array}$ & & $\begin{array}{l}113 \text { per } 1000 \\
(23 / 203)\end{array}$ & $\begin{array}{l}112 \text { per } 1000 \\
\text { (65 to } 195)\end{array}$ & $\begin{array}{l}\text { RR } 0.99(0.57 \\
\text { to } 1.72)\end{array}$ & 399 (1 RCT) & MODERATE & $\begin{array}{l}\text { Imprecision (-1): wide } \\
\mathrm{Cl} \text { crossing line of no } \\
\text { effect }\end{array}$ \\
\hline $\begin{array}{l}\text { Volume vs no } \\
\text { treatment for } \\
\text { prevention of } \\
\text { morbidity and } \\
\text { mortality in } \\
\text { very preterm in- } \\
\text { fants (Osborn } \\
\text { 2004) }\end{array}$ & $\begin{array}{l}\text { Death or severe neurodevelopmental } \\
\text { disability in survivors at } 2 \text { years (de- } \\
\text { fined as blind, dead, unable to walk, } \\
\text { DQ > } 3 \text { SD below the mean, or another } \\
\text { severe disability) }\end{array}$ & $\begin{array}{l}318 \text { per } 1000 \\
(82 / 258)\end{array}$ & $\begin{array}{l}318 \text { per } 1000 \\
\text { (254 to } 394)\end{array}$ & $\begin{array}{l}\text { RR } 1.00(0.80 \\
\text { to } 1.24)\end{array}$ & $776(1 \mathrm{RCT})$ & MODERATE & $\begin{array}{l}\text { Imprecision (-1): wide } \\
\mathrm{Cl} \text { crossing line of no } \\
\text { effect }\end{array}$ \\
\hline
\end{tabular}




\begin{tabular}{|c|c|c|c|c|c|c|c|c|}
\hline $\begin{array}{l}\text { Gelatin vs fresh } \\
\text { frozen plasma } \\
\text { for prevention } \\
\text { of morbidity } \\
\text { and mortality } \\
\text { in very preterm } \\
\text { infants (Osborn } \\
\text { 2004) }\end{array}$ & & $\begin{array}{l}300 \text { per } 1000 \\
(77 / 257)\end{array}$ & $\begin{array}{l}333 \text { per } 1000 \\
(258 \text { to } 428)\end{array}$ & $\begin{array}{l}\mathrm{RR} 1.11(0.86 \\
\text { to } 1.43)\end{array}$ & $518(1 \mathrm{RCT})$ & MODERATE & $\begin{array}{l}\text { Imprecision }(-1) \text { : wide } \\
\mathrm{Cl} \text { crossing line of no } \\
\text { effect }\end{array}$ & 둘율 \\
\hline \multicolumn{8}{|c|}{ Neonatal care: patent ductus arteriosus } & 50 \\
\hline $\begin{array}{l}\text { Prophylactic in- } \\
\text { domethacin vs } \\
\text { placebo for pre- } \\
\text { venting mortal- } \\
\text { ity and morbid- } \\
\text { ity in preterm } \\
\text { infants (Fowlie } \\
\text { 2010) }\end{array}$ & $\begin{array}{l}\text { Death or severe neurodevelopmental } \\
\text { disability at } 18 \text { to } 36 \text { months (defined } \\
\text { as any } 1 \text { or a combination of the fol- } \\
\text { lowing: non-ambulant cerebral palsy, } \\
\text { developmental delay (DQ }<70) \text {, audi- } \\
\text { tory and visual impairment) }\end{array}$ & $\begin{array}{l}400 \text { per } 1000 \\
(299 / 748)\end{array}$ & $\begin{array}{l}407 \text { per } 1000 \\
(360 \text { to } 460)\end{array}$ & $\begin{array}{l}\text { RR } 1.02(0.90 \\
\text { to } 1.15)\end{array}$ & 1491 (3 RCTs) & MODERATE & $\begin{array}{l}\text { Study limitations }(-1) \text { : } \\
2 \text { RCTs at unclear risk } \\
\text { of attrition bias (> 25\% } \\
\text { loss to follow-up) }\end{array}$ & 苛 \\
\hline \multicolumn{8}{|c|}{ Neonatal care: blood disorders } & \\
\hline $\begin{array}{l}\text { Erythropoi- } \\
\text { etin vs placebo } \\
\text { for preventing } \\
\text { red blood cell } \\
\text { transfusion in } \\
\text { preterm and/or } \\
\text { low birthweight } \\
\text { infants (Ohls- } \\
\text { son 2014) }\end{array}$ & $\begin{array}{l}\text { Any neurodevelopmental impairment } \\
\text { at } 18 \text { to } 22 \text { months' corrected age (in } \\
\text { children examined) (not defined in re- } \\
\text { view; definition from trial manuscript: } \\
1 \text { of the following: MDI }<70, \text { PDI }<70 \text {, } \\
\text { moderate or severe cerebral palsy, } \\
\text { blindness, or deafness) }\end{array}$ & $\begin{array}{l}451 \text { per } 1000 \\
(23 / 51)\end{array}$ & $\begin{array}{l}437 \text { per } 1000 \\
(280 \text { to } 681)\end{array}$ & $\begin{array}{l}\text { RR } 0.97(0.62 \\
\text { to } 1.51)\end{array}$ & $99(1 \mathrm{RCT})$ & VERY LOW & $\begin{array}{l}\text { Study limitations: } 1 \\
\text { RCT at unclear risk of } \\
\text { selection bias and high } \\
\text { risk of attrition bias } \\
\text { ( } 73 \% \text { follow-up) } \\
\text { Imprecision (-2): wide } \\
\text { Cl crossing line of } \\
\text { no effect; } 1 \text { RCT with } \\
\text { small sample size }\end{array}$ & \\
\hline \multirow[t]{2}{*}{$\begin{array}{l}\text { Transfusion at a } \\
\text { restrictive vs a } \\
\text { liberal haemo- } \\
\text { globin thresh- } \\
\text { old for prevent- } \\
\text { ing morbidity } \\
\text { and mortality in } \\
\text { very low birth- } \\
\text { weight infants } \\
\text { (Whyte 2011) }\end{array}$} & $\begin{array}{l}\text { Any neurosensory impairment at } 18 \text { to } \\
21 \text { months' follow-up among survivors } \\
\text { (defined as cognitive delay (MDI }<70 \text { ), } \\
\text { cerebral palsy, severe visual impair- } \\
\text { ment, severe hearing impairment) }\end{array}$ & $\begin{array}{l}220 \text { per } 1000 \\
(37 / 168)\end{array}$ & $\begin{array}{l}289 \text { per } 1000 \\
(198 \text { to } 418)\end{array}$ & $\begin{array}{l}\operatorname{RR} 1.31(0.90 \\
\text { to } 1.90)\end{array}$ & $328(1 \mathrm{RCT})$ & LOW & $\begin{array}{l}\text { Study limitations }(-1) \text { : } \\
1 \text { RCT at high risk of } \\
\text { performance bias and } \\
\text { unclear risk of report- } \\
\text { ing bias } \\
\text { Imprecision }(-1) \text { : wide } \\
\mathrm{Cl} \text { crossing line of no } \\
\text { effect }\end{array}$ & 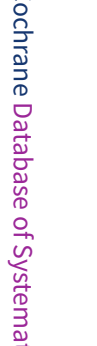 \\
\hline & $\begin{array}{l}\text { Death or severe morbidity at } 18 \text { to } 21 \\
\text { months' follow-up (defined as cogni- }\end{array}$ & 385 per 1000 & $\begin{array}{l}450 \text { per } 1000 \\
(362 \text { to } 566)\end{array}$ & $\begin{array}{l}\text { RR } 1.17(0.94 \\
\text { to } 1.47)\end{array}$ & $421(1 \mathrm{RCT})$ & LOW & $\begin{array}{l}\text { Study limitations }(-1) \text { : } \\
1 \text { RCT at high risk of }\end{array}$ & 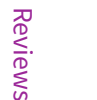 \\
\hline
\end{tabular}




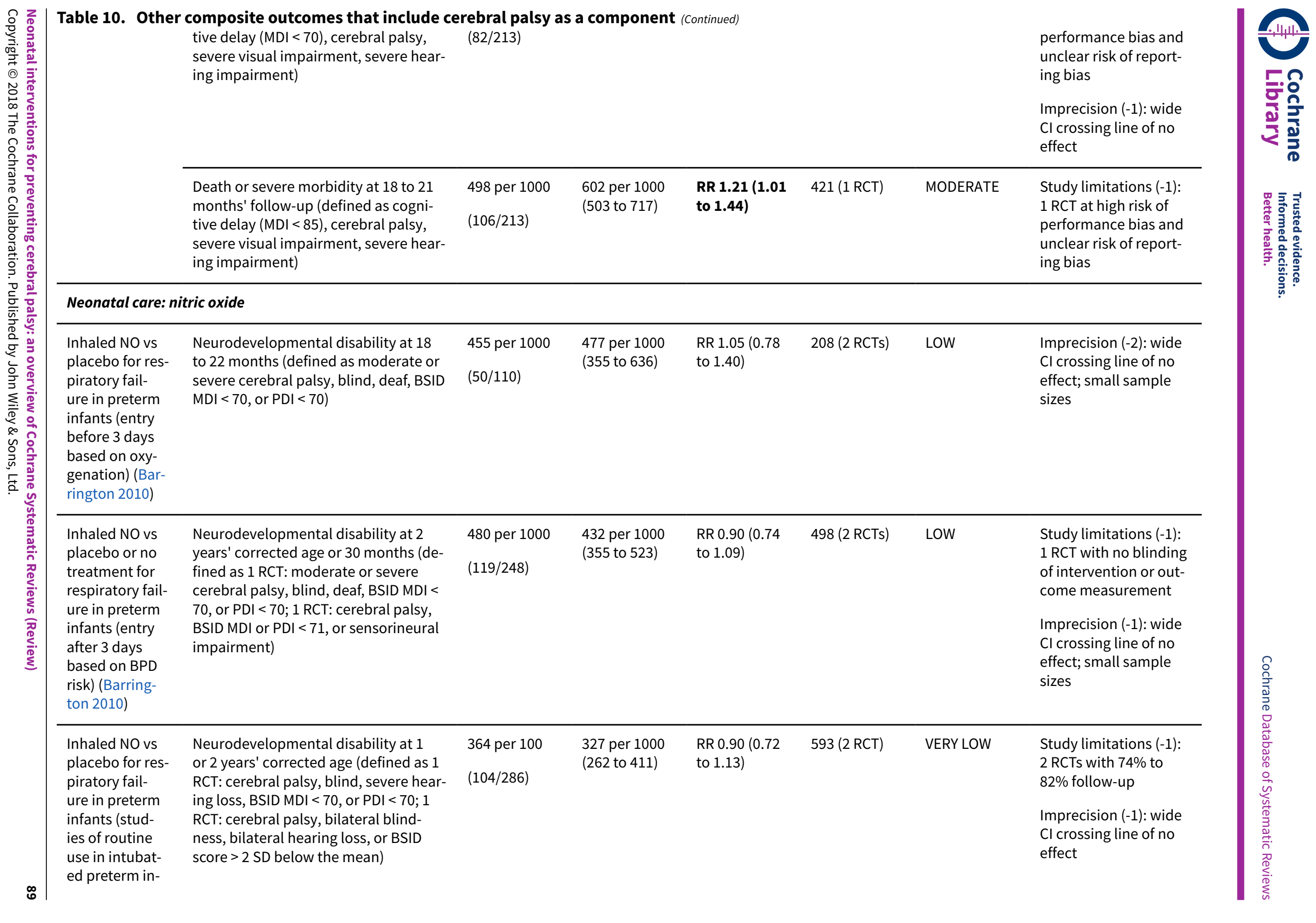




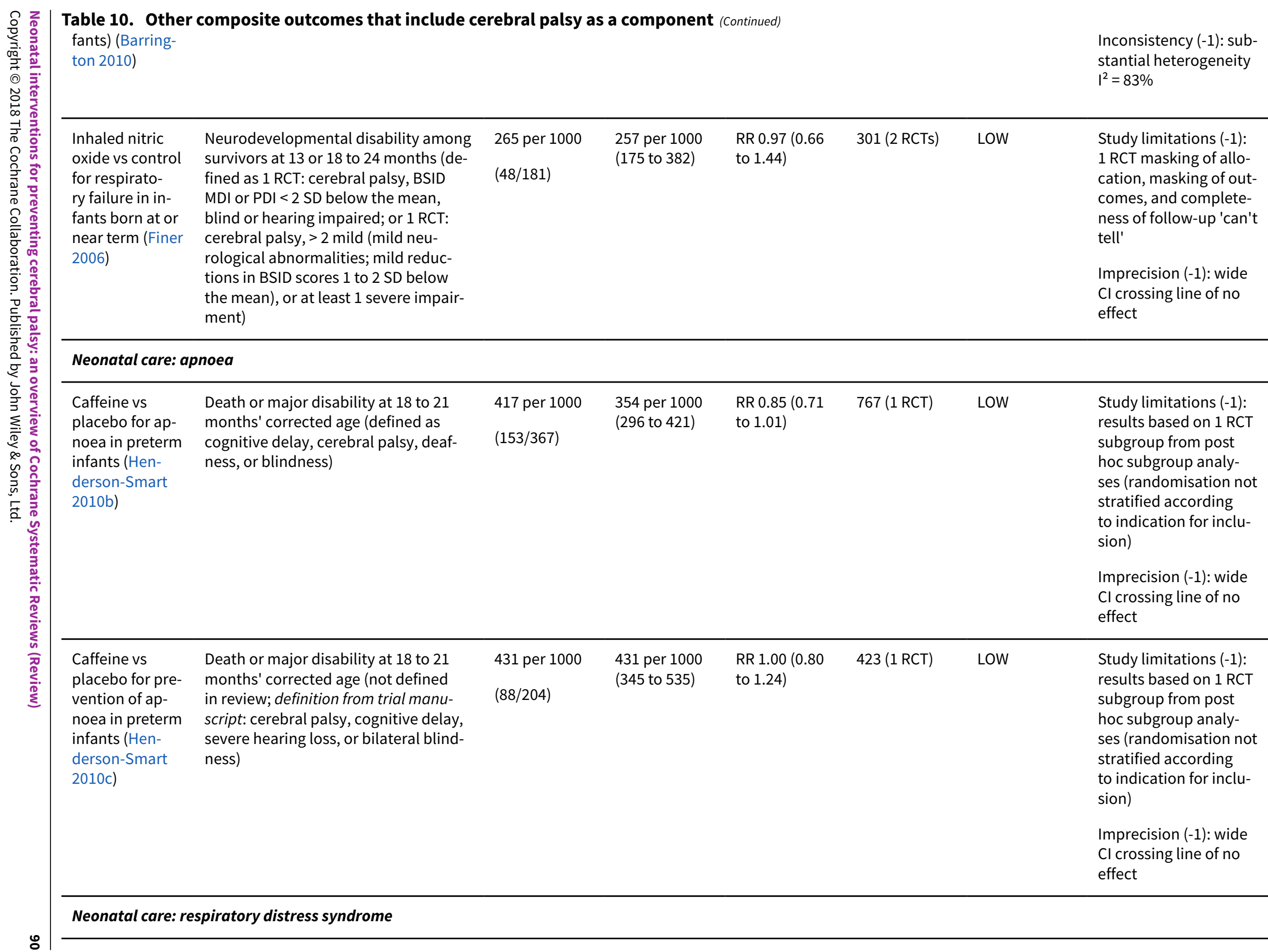




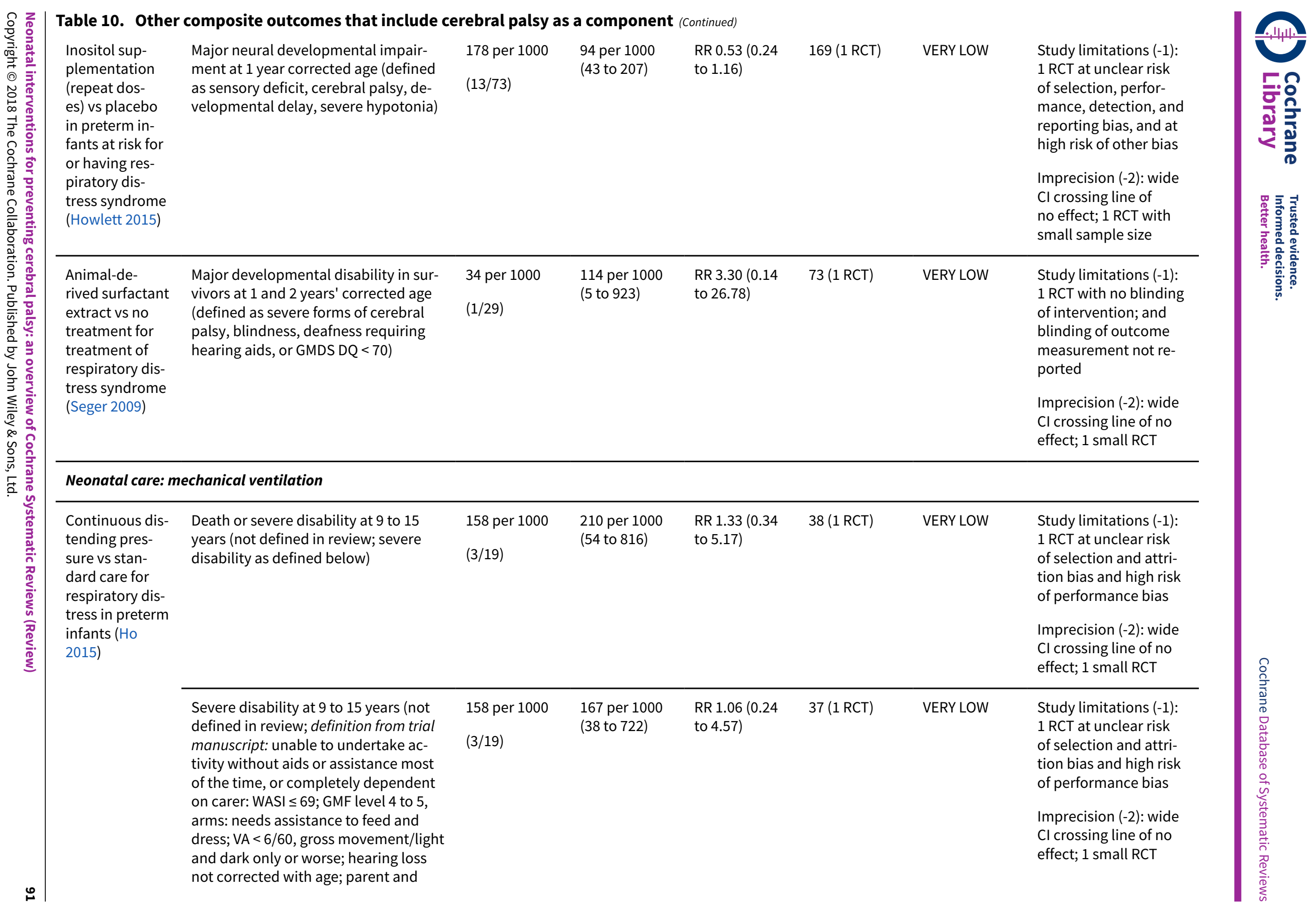




\begin{tabular}{|c|c|c|c|c|c|c|c|c|}
\hline & $\begin{array}{l}\text { teacher overall difficulties (Q26), "Yes" } \\
\text { and impact score } 6 \text { to } 10 \text { parent and } 3 \\
\text { to } 6 \text { teacher; or other condition needs } \\
\text { supervision/aid constantly - includes } \\
\text { continuous home oxygen; communi- } \\
\text { cation severely limited) }\end{array}$ & & & & & & & 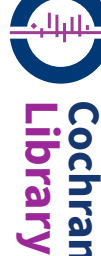 \\
\hline & $\begin{array}{l}\text { Any disability at } 9 \text { to } 15 \text { years (not de- } \\
\text { fined in review; definition from trial } \\
\text { manuscript: mild: some loss of func- } \\
\text { tion but able to function independent- } \\
\text { ly; moderate: aids or assistance need- } \\
\text { ed for some tasks. Moderate difficul- } \\
\text { ty in doing some activities; severe: un- } \\
\text { able to undertake activity without aids } \\
\text { or assistance most of the time, or com- } \\
\text { pletely dependent on carer; includes } \\
\text { neuromotor components includes } \\
\text { GMF levels } 1 \text { to 5) }\end{array}$ & $\begin{array}{l}632 \text { per } 1000 \\
(12 / 19)\end{array}$ & $\begin{array}{l}392 \text { per } 1000 \\
(196 \text { to } 764)\end{array}$ & $\begin{array}{l}\text { RR } 0.62(0.31 \\
\text { to } 1.21)\end{array}$ & 37 (1 RCT) & VERY LOW & $\begin{array}{l}\text { Study limitations (-1): } \\
1 \text { RCT at unclear risk } \\
\text { of selection and attri- } \\
\text { tion bias and high risk } \\
\text { of performance bias } \\
\text { Imprecision (-2): wide } \\
\text { Cl crossing line of no } \\
\text { effect; } 1 \text { small RCT }\end{array}$ & 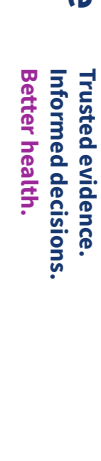 \\
\hline $\begin{array}{l}\text { Prophylac- } \\
\text { tic methylx- } \\
\text { anthines (caf- } \\
\text { feine) vs place- } \\
\text { bo for endotra- } \\
\text { cheal extuba- } \\
\text { tion in preterm } \\
\text { infants (Hen- } \\
\text { derson-Smart } \\
\text { 2010) }\end{array}$ & $\begin{array}{l}\text { Death or major disability at } 18 \text { to } 21 \\
\text { months' corrected age (defined as } \\
\text { cognitive delay, cerebral palsy, deaf- } \\
\text { ness, or blindness) }\end{array}$ & $\begin{array}{l}525 \text { per } 1000 \\
(189 / 360)\end{array}$ & $\begin{array}{l}446 \text { per } 1000 \\
(383 \text { to } 520)\end{array}$ & $\begin{array}{l}\text { RR } 0.85(0.73 \\
\text { to } 0.99)\end{array}$ & 676 (1 RCT) & MODERATE & $\begin{array}{l}\text { Study limitations }(-1) \text { : } \\
\text { results based on } 1 \mathrm{RCT} \\
\text { subgroup from post } \\
\text { hoc subgroup analy- } \\
\text { ses (randomisation not } \\
\text { stratified according } \\
\text { to indication for inclu- } \\
\text { sion) }\end{array}$ & \\
\hline \multirow[t]{2}{*}{$\begin{array}{l}\text { Volume-tar- } \\
\text { geted vs pres- } \\
\text { sure-limited } \\
\text { ventilation in } \\
\text { the neonate } \\
\text { (Wheeler 2010) }\end{array}$} & $\begin{array}{l}\text { Severe disability (any definition) at } 6 \\
\text { to } 18 \text { months and } 22 \text { months (defin- } \\
\text { itions not reported in review; defini- } \\
\text { tions from trial manuscripts: } 1 \text { RCT: ab- } \\
\text { normal neurological evaluation (gross } \\
\text { or fine motor delay) or BSID MDI < 70; } \\
1 \text { RCT: cerebral palsy severe enough to } \\
\text { hamper gross motor activity, deafness } \\
\text { needing hearing aids, registered blind } \\
\text { or partially sighted) }\end{array}$ & $\begin{array}{l}176 \text { per } 1000 \\
(18 / 102)\end{array}$ & $\begin{array}{l}152 \text { per } 1000 \\
(83 \text { to } 281)\end{array}$ & $\begin{array}{l}\text { RR } 0.86(0.47 \\
\text { to } 1.59)\end{array}$ & 209 (2 RCTs) & LOW & $\begin{array}{l}\text { Indirectness (-1): post } \\
\text { hoc analysis including } \\
2 \text { RCTs with varied def- } \\
\text { initions } \\
\text { Imprecision (-1): wide } \\
\text { Cl crossing line of no } \\
\text { effect } \\
\text { (post hoc analysis in re- } \\
\text { view) }\end{array}$ & 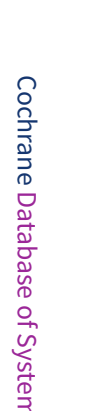 \\
\hline & $\begin{array}{l}\text { Severe disability (any definition) at } \\
22 \text { months or death (definition not re- } \\
\text { ported in review; definition from tri- }\end{array}$ & $\begin{array}{l}327 \text { per } 1000 \\
(17 / 52)\end{array}$ & $\begin{array}{l}177 \text { per } 1000 \\
(88 \text { to } 347)\end{array}$ & $\begin{array}{l}\text { RR } 0.54(0.27 \\
\text { to } 1.06)\end{array}$ & 109 (1 RCT) & LOW & $\begin{array}{l}\text { Imprecision (-2): wide } \\
\mathrm{Cl} \text { crossing line of no } \\
\text { effect; } 1 \text { small RCT }\end{array}$ & 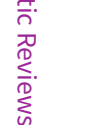 \\
\hline
\end{tabular}




\begin{tabular}{|c|c|c|c|c|c|c|c|}
\hline & $\begin{array}{l}\text { al manuscript: cerebral palsy severe } \\
\text { enough to hamper gross motor activi- } \\
\text { ty, deafness needing hearing aids, reg- } \\
\text { istered blind or partially sighted) }\end{array}$ & & & & & & $\begin{array}{l}\text { (post hoc analysis in re- } \\
\text { view) }\end{array}$ \\
\hline \multicolumn{8}{|c|}{ Neonatal care: bronchopulmonary dysplasia } \\
\hline \multirow[t]{3}{*}{$\begin{array}{l}\text { Early (<8 days) } \\
\text { postnatal cor- } \\
\text { ticosteroids } \\
\text { vs placebo or } \\
\text { no treatment } \\
\text { for prevent- } \\
\text { ing chronic } \\
\text { lung disease in } \\
\text { preterm infants } \\
\text { (Doyle 2014b) }\end{array}$} & $\begin{array}{l}\text { Major neurosensory disability at } 18 \text { to } \\
22 \text { months to } 53 \text { months (variable cri- } \\
\text { teria reported in review: } 1 \text { RCT: non- } \\
\text { ambulant cerebral palsy, global retar- } \\
\text { dation (not specified), blindness, or } \\
\text { deafness; } 1 \text { RCT: moderate or severe } \\
\text { cerebral palsy, blindness, deafness, or } \\
\text { BSID MDI or PDI <-2 SD; } 1 \text { RCT: cere- } \\
\text { bral palsy, BSID MDI or PDI < 71, blind- } \\
\text { ness or deafness; } 1 \text { RCT: severe motor } \\
\text { dysfunction (child non-ambulant), or } \\
\text { BSID MDI or PDI <-2 SD; } 2 \text { RCTs: cere- } \\
\text { bral palsy, blindness, deafness, or de- } \\
\text { velopmental delay (BSID MDI < 70 (< } \\
-2 \text { SD) or GMDS DQ < } 70) ; 1 \text { RCT: cere- } \\
\text { bral palsy, functional blindness, func- } \\
\text { tional deafness, developmental delay } \\
\text { (BSID MDI < } 70 \text { (<-2 SD)), or motor de- } \\
\text { lay (BSID PDI < } 70 \text { (<-2 SD)) }\end{array}$ & $\begin{array}{l}199 \text { per } 1000 \\
(121 / 607)\end{array}$ & $\begin{array}{l}231 \text { per } 1000 \\
\text { (187 to } 285)\end{array}$ & $\begin{array}{l}\text { RR } 1.16(0.94 \\
\text { to } 1.43)\end{array}$ & 1233 (7 RCTs) & LOW & $\begin{array}{l}\text { Study limitations }(-1) \text { : } \\
2 \text { RCTs at unclear risk } \\
\text { of selection bias; } 1 \text { RCT } \\
\text { at high risk of perfor- } \\
\text { mance and detection } \\
\text { bias } \\
\text { Imprecision (-1): wide } \\
\mathrm{Cl} \text { crossing line of no } \\
\text { effect }\end{array}$ \\
\hline & $\begin{array}{l}\text { Major neurosensory disability in sur- } \\
\text { vivors examined at } 18 \text { to } 22 \text { months to } \\
53 \text { months (variable criteria as above) }\end{array}$ & $\begin{array}{l}307 \text { per } 1000 \\
(121 / 394)\end{array}$ & $\begin{array}{l}350 \text { per } 1000 \\
(289 \text { to } 424)\end{array}$ & $\begin{array}{l}\text { RR } 1.14(0.94 \\
\text { to } 1.38)\end{array}$ & 799 (7 RCTs) & LOW & $\begin{array}{l}\text { Study limitations }(-1) \text { : } \\
2 \text { RCTs at unclear risk } \\
\text { of selection bias; } 1 \text { RCT } \\
\text { at high risk of perfor- } \\
\text { mance and detection } \\
\text { bias } \\
\text { Imprecision (-1): wide } \\
\mathrm{Cl} \text { crossing line of no } \\
\text { effect }\end{array}$ \\
\hline & $\begin{array}{l}\text { Death or major neurosensory disability } \\
\text { at } 18 \text { to } 22 \text { months to } 53 \text { months (vari- } \\
\text { able criteria as above) }\end{array}$ & $\begin{array}{l}466 \text { per } 1000 \\
(283 / 607)\end{array}$ & $\begin{array}{l}490 \text { per } 1000 \\
\text { ( } 434 \text { to } 545)\end{array}$ & $\begin{array}{l}\text { RR } 1.05(0.93 \\
\text { to } 1.17)\end{array}$ & 1233 (7 RCTs) & MODERATE & $\begin{array}{l}\text { Study limitations (-1): } \\
2 \text { RCTs at unclear risk } \\
\text { of selection bias; } 1 \text { RCT } \\
\text { at high risk of perfor- } \\
\text { mance and detection } \\
\text { bias }\end{array}$ \\
\hline
\end{tabular}




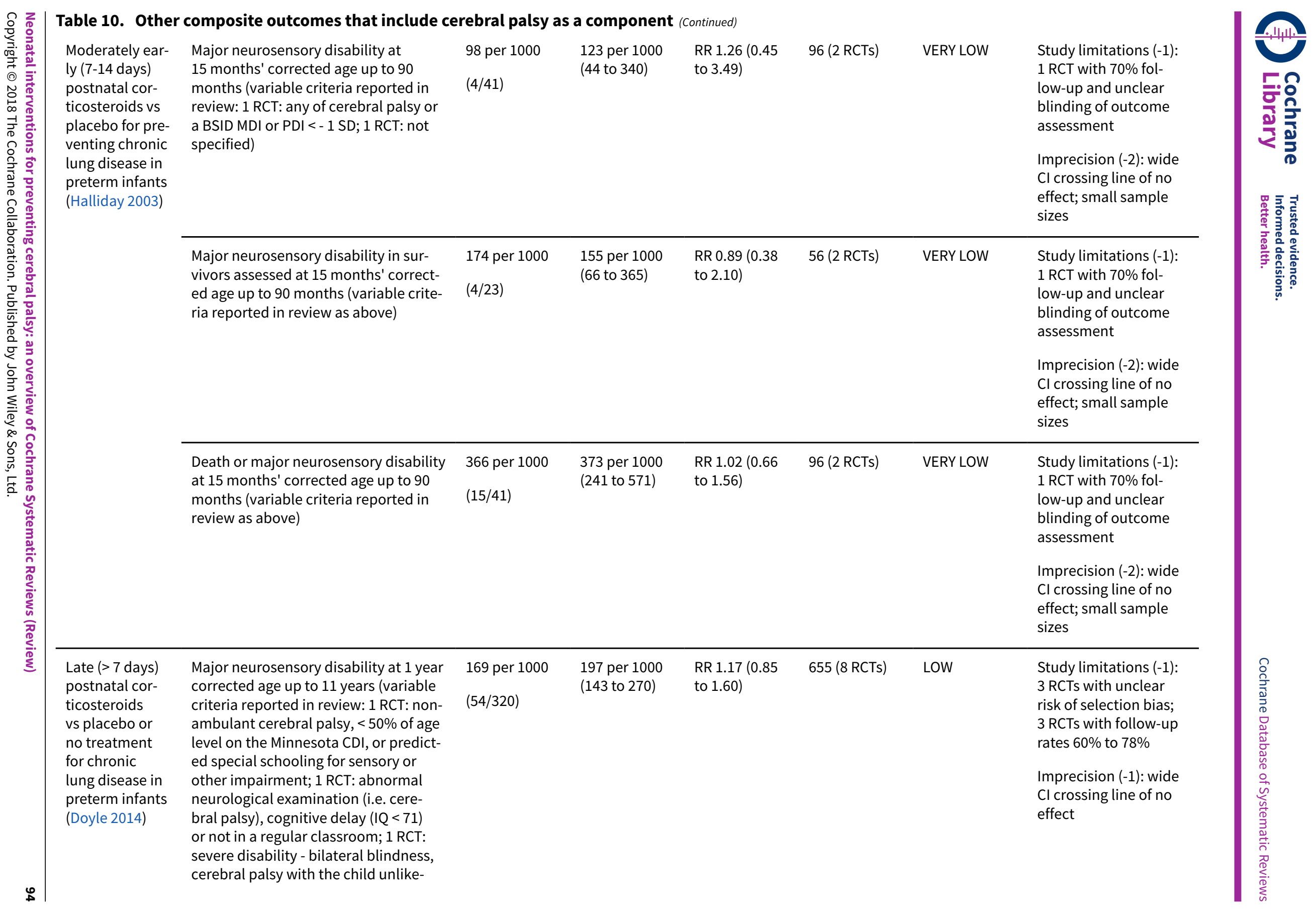




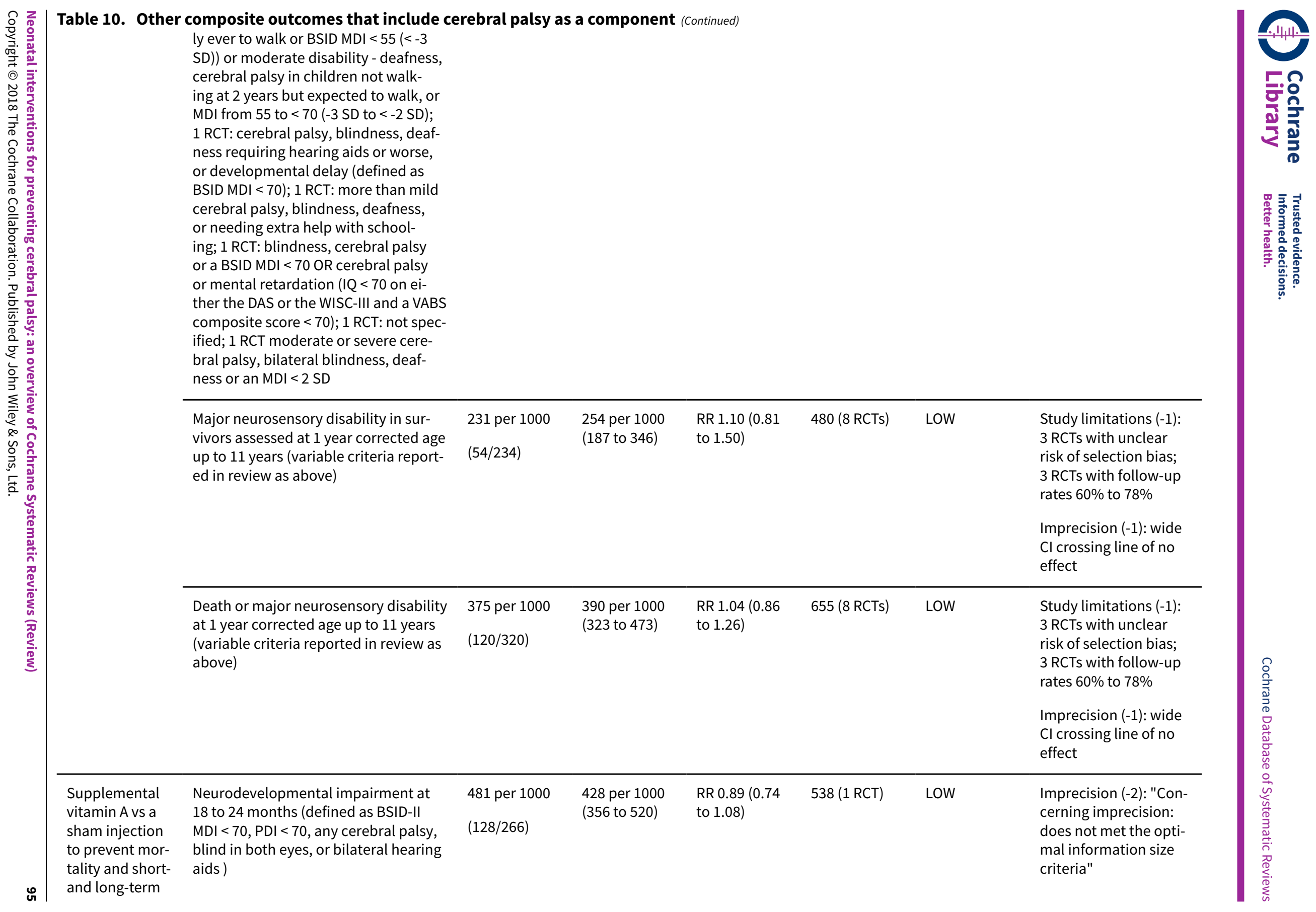




\begin{tabular}{|c|c|c|c|c|c|c|c|}
\hline \multirow{2}{*}{$\begin{array}{l}\text { morbidity in } \\
\text { very low birth- } \\
\text { weight infants } \\
\text { (Darlow 2016) }\end{array}$} & & & & & & & \multirow{2}{*}{$\begin{array}{l}\text { (graded by review au- } \\
\text { thors themselves) } \\
\text { Imprecision (-1): wide } \\
\text { Cls crossing line of no } \\
\text { effect }\end{array}$} \\
\hline & $\begin{array}{l}\text { Death or neurodevelopmental impair- } \\
\text { ment at } 18 \text { to } 24 \text { months (defined as } \\
\text { BSID-II MDI }<70, \mathrm{PDI}<70 \text {, any cerebral } \\
\text { palsy, blind in both eyes, or bilateral } \\
\text { hearing aids) }\end{array}$ & $\begin{array}{l}596 \text { per } 1000 \\
(204 / 342)\end{array}$ & $\begin{array}{l}549 \text { per } 1000 \\
(483 \text { to } 626)\end{array}$ & $\begin{array}{l}\text { RR } 0.92(0.81 \\
\text { to } 1.05)\end{array}$ & $687(1 \mathrm{RCT})$ & MODERATE & \\
\hline \multicolumn{8}{|c|}{ Neonatal care: necrotising enterocolitis } \\
\hline $\begin{array}{l}\text { Probiotics vs } \\
\text { control (dis- } \\
\text { tilled water) for } \\
\text { prevention of } \\
\text { necrotising en- } \\
\text { terocolitis in } \\
\text { preterm infants } \\
\text { (AlFaleh 2014) }\end{array}$ & $\begin{array}{l}\text { Mental retardation and cerebral palsy } \\
\text { at } 6 \text { years }\end{array}$ & $\begin{array}{l}47 \text { per } 1000 \\
(2 / 43)\end{array}$ & $\begin{array}{l}47 \text { per } 1000(7 \\
\text { to } 323)\end{array}$ & $\begin{array}{l}\text { RR } 1.02(0.15 \\
\text { to } 6.94)\end{array}$ & 85 (1 RCT) & VERY LOW & $\begin{array}{l}\text { Study limitation (-1): } \\
1 \text { RCT at unclear risk } \\
\text { for selection, perfor- } \\
\text { mance, and detection } \\
\text { bias; and high risk of } \\
\text { attrition and reporting } \\
\text { bias } \\
\text { Imprecision (-2): wide } \\
\text { CI crossing line of no } \\
\text { effect; } 1 \text { small RCT }\end{array}$ \\
\hline $\begin{array}{l}\text { Arginine sup- } \\
\text { plementation } \\
\text { vs placebo for } \\
\text { prevention of } \\
\text { necrotising en- } \\
\text { terocolitis in } \\
\text { preterm infants } \\
\text { (Shah 2007) }\end{array}$ & $\begin{array}{l}\text { Major neurodevelopmental disability } \\
\text { at } 36 \text { months' post-menstrual age (de- } \\
\text { finition not reported in review; defini- } \\
\text { tion from trial manuscript: presence of } \\
1 \text { or more of cerebral palsy, cognitive } \\
\text { delay (index }<70 \text { ), bilateral blindness, } \\
\text { bilateral hearing loss requiring aids) }\end{array}$ & $\begin{array}{l}127 \text { per } 1000 \\
(9 / 71)\end{array}$ & $\begin{array}{l}82 \text { per } 1000 \\
(29 \text { to } 232)\end{array}$ & $\begin{array}{l}\text { RR } 0.65(0.23 \\
\text { to } 1.83)\end{array}$ & $132(1 \mathrm{RCT})$ & LOW & $\begin{array}{l}\text { Imprecision (-2): wide } \\
\mathrm{Cl} \text { crossing line of no } \\
\text { effect; } 1 \text { small RCT }\end{array}$ \\
\hline \multicolumn{8}{|c|}{ Neonatal care: fungal infections } \\
\hline $\begin{array}{l}\text { Systemic anti- } \\
\text { fungal agent vs } \\
\text { placebo to pre- } \\
\text { vent mortali- } \\
\text { ty and morbid- } \\
\text { ity in very low } \\
\text { birthweight in- } \\
\text { fants (Clemin- } \\
\text { son 2015) }\end{array}$ & $\begin{array}{l}\text { Neurodevelopmental impairment } \\
\text { (composite) at } 18 \text { to } 22 \text { months (de- } \\
\text { fined as at least } 1 \text { of (i) BSID-III cogni- } \\
\text { tion composite score }<70 \text {, (ii) cerebral } \\
\text { palsy, (iii) deafness or, (iv) blindness) }\end{array}$ & $\begin{array}{l}274 \text { per } 1000 \\
(23 / 84)\end{array}$ & $\begin{array}{l}309 \text { per } 1000 \\
(194 \text { to } 496)\end{array}$ & $\begin{array}{l}\text { RR } 1.13(0.71 \\
\text { to } 1.81)\end{array}$ & $171(1 \mathrm{RCT})$ & LOW & $\begin{array}{l}\text { Imprecision (-2): wide } \\
\mathrm{Cl} \text { crossing line of no } \\
\text { effect; } 1 \text { small RCT }\end{array}$ \\
\hline
\end{tabular}




\begin{tabular}{|c|c|c|c|c|c|c|c|}
\hline \multicolumn{8}{|c|}{ Neonatal care: herpes simplex } \\
\hline \multirow[t]{2}{*}{$\begin{array}{l}\text { Vidarabine vs } \\
\text { placebo for } \\
\text { treatment of } \\
\text { herpes simplex } \\
\text { virus infection } \\
\text { in neonates } \\
\text { (Jones 2009) }\end{array}$} & $\begin{array}{l}\text { Abnormal neurodevelopment at ap- } \\
\text { proximately } 1 \text { year of age (not defined } \\
\text { in review; definition from trial manu- } \\
\text { script: spasticity or hemiparesis on- } \\
\text { ly; or combinations of microcephaly, } \\
\text { paresis, spasticity, seizures, blindness, } \\
\text { or deafness) }\end{array}$ & $\begin{array}{l}214 \text { per } 1000 \\
(6 / 28)\end{array}$ & $\begin{array}{l}321 \text { per } 1000 \\
\text { (133 to } 782 \text { ) }\end{array}$ & $\begin{array}{l}\text { RR } 1.50(0.62 \\
\text { to } 3.65)\end{array}$ & $56(1 \mathrm{RCT})$ & VERY LOW & $\begin{array}{l}\text { Study limitations (-1): } \\
1 \text { RCT with design lim- } \\
\text { itations (method of } \\
\text { randomisation not } \\
\text { stated) } \\
\text { Imprecision (-2): wide } \\
\text { Cls crossing line of no } \\
\text { effect; } 1 \text { small RCT }\end{array}$ \\
\hline & $\begin{array}{l}\text { Abnormal neurodevelopment or death } \\
\text { at approximately } 1 \text { year of age (not } \\
\text { defined in review; definition from trial } \\
\text { manuscript as above) }\end{array}$ & $\begin{array}{l}750 \text { per } 1000 \\
(21 / 28)\end{array}$ & $\begin{array}{l}645 \text { per } 1000 \\
(450 \text { to } 915)\end{array}$ & $\begin{array}{l}\mathrm{RR} 0.86(0.60 \\
\text { to } 1.22)\end{array}$ & 56 (1 RCT) & VERY LOW & $\begin{array}{l}\text { Study limitations (-1): } \\
1 \text { RCT with design lim- } \\
\text { itations (method of } \\
\text { randomisation not } \\
\text { stated) } \\
\text { Imprecision (-2): wide } \\
\text { Cls crossing line of no } \\
\text { effect; } 1 \text { small RCT }\end{array}$ \\
\hline \multirow[t]{2}{*}{$\begin{array}{l}\text { Aciclovir vs vi- } \\
\text { darabine for } \\
\text { treatment of } \\
\text { herpes simplex } \\
\text { virus infection } \\
\text { in neonates } \\
\text { (Jones 2009) }\end{array}$} & $\begin{array}{l}\text { Abnormal neurodevelopment at ap- } \\
\text { proximately } 1 \text { year of age (not defined } \\
\text { in review; definition from trial manu- } \\
\text { script: mild impairment: only occular } \\
\text { sequelae; moderate neurological im- } \\
\text { pairment: hemiparesis or a persistent } \\
\text { seizure disorder and no more than a } \\
\text { 3-month developmental delay; severe } \\
\text { neurological sequelae: microcephaly, } \\
\text { spastic quadriplegia, chorioretinitis or } \\
\text { blindness, and a serious developmen- } \\
\text { tal delay of }>3 \text { months according to } \\
\text { the DDST) }\end{array}$ & $\begin{array}{l}263 \text { per } 1000 \\
(25 / 95)\end{array}$ & $\begin{array}{l}216 \text { per } 1000 \\
(132 \text { to } 353)\end{array}$ & $\begin{array}{l}\mathrm{RR} 0.82(0.50 \\
\text { to } 1.34)\end{array}$ & 202 (1 RCT) & VERY LOW & $\begin{array}{l}\text { Study limitations (-1): } \\
1 \text { RCT with design limi- } \\
\text { tations (inadequate al- } \\
\text { location concealment) } \\
\text { Imprecision (-2): wide } \\
\text { Cls crossing line of no } \\
\text { effect; } 1 \text { small RCT }\end{array}$ \\
\hline & $\begin{array}{l}\text { Abnormal neurodevelopment or death } \\
\text { at approximately } 1 \text { year of age (not } \\
\text { defined in review definition from trial } \\
\text { manuscript as above) }\end{array}$ & $\begin{array}{l}463 \text { per } 1000 \\
(44 / 95)\end{array}$ & $\begin{array}{l}366 \text { per } 1000 \\
(264 \text { to } 509)\end{array}$ & $\begin{array}{l}\text { RR } 0.79(0.57 \\
\text { to } 1.10)\end{array}$ & 202 (1 RCT) & VERY LOW & $\begin{array}{l}\text { Study limitations (-1): } \\
1 \text { RCT with design limi- } \\
\text { tations (inadequate al- } \\
\text { location concealment) } \\
\text { Imprecision (-2): wide } \\
\text { Cls crossing line of no } \\
\text { effect; } 1 \text { small RCT }\end{array}$ \\
\hline
\end{tabular}




\begin{tabular}{|c|c|c|c|c|c|c|c|c|}
\hline \multicolumn{8}{|c|}{ Neonatal care: jaundice } & \multirow{3}{*}{ 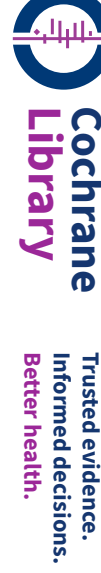 } \\
\hline $\begin{array}{l}\text { Prophylactic } \\
\text { photothera- } \\
\text { py vs standard } \\
\text { care for pre- } \\
\text { venting jaun- } \\
\text { dice in preterm } \\
\text { or low birth- } \\
\text { weight infants } \\
\text { (Okwundu } \\
\text { 2012) }\end{array}$ & $\begin{array}{l}\text { Neurodevelopmental impairment at } \\
18 \text { to } 22 \text { months (defined as blindness, } \\
\text { severe hearing loss, and moderate or } \\
\text { severe cerebral palsy) }\end{array}$ & $\begin{array}{l}305 \text { per } 1000 \\
(275 / 902)\end{array}$ & $\begin{array}{l}259 \text { per } 1000 \\
\text { (226 to } 302)\end{array}$ & $\begin{array}{l}\text { RR } 0.85(0.74 \\
\text { to } 0.99)\end{array}$ & 1804 (1 RCT) & MODERATE & $\begin{array}{l}\text { Study limitations }(-1) \text { : } \\
1 \text { RCT with high risk of } \\
\text { attrition bias }\end{array}$ & \\
\hline \multicolumn{8}{|c|}{ Neonatal care: hypoglycaemia } & \\
\hline \multirow[t]{2}{*}{$\begin{array}{l}\text { Dextrose gel } \\
\text { vs placebo for } \\
\text { treatment of } \\
\text { hypoglycaemia } \\
\text { in newborn in- } \\
\text { fants (Weston } \\
\text { 2016) }\end{array}$} & $\begin{array}{l}\text { Major neurosensory disability at } 2 \\
\text { years (defined as any of the following: } \\
\text { legal blindness, sensorineural deaf- } \\
\text { ness requiring hearing aids, moderate } \\
\text { or severe cerebral palsy, developmen- } \\
\text { tal delay/intellectual impairment (de- } \\
\text { fined as DQ }<2 \text { SD below the mean)) }\end{array}$ & $\begin{array}{l}11 \text { per } 1000 \\
(1 / 94)\end{array}$ & $\begin{array}{l}67 \text { per } 1000(8 \\
\text { to } 543)\end{array}$ & $\begin{array}{l}\text { RR } 6.27(0.77 \\
\text { to } 51.03)\end{array}$ & $184(1 \mathrm{RCT})$ & VERY LOW & $\begin{array}{l}\text { Study limitations (-1): } \\
\text { "Evidence is based on } \\
\text { a single trial" } \\
\text { Imprecision (-2): "Wide } \\
\text { confidence intervals, } \\
\text { low event rates and } \\
\text { small sample sizes are } \\
\text { suggestive of impreci- } \\
\text { sion: } \\
\text { (graded by review au- } \\
\text { thors themselves) }\end{array}$ & \\
\hline & $\begin{array}{l}\text { Developmental disability at } 2 \text { years } \\
\text { (defined as cognitive, language, or mo- } \\
\text { tor score below - } 1 \text { SD, or cerebral pal- } \\
\text { sy, blindness, or deafness) }\end{array}$ & $32 / 94$ & $34 / 90$ & $\begin{array}{l}\text { RR } 1.11(0.75 \\
\text { to } 1.63)\end{array}$ & $184(1 \mathrm{RCT})$ & VERY LOW & $\begin{array}{l}\text { Study limitations }(-1) \text { : } \\
1 \text { RCT with } 78 \% \text { fol- } \\
\text { low-up } \\
\text { Imprecision: wide } \mathrm{Cl} \\
\text { crossing line of no ef- } \\
\text { fect; } 1 \text { small RCT }\end{array}$ & 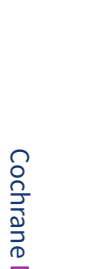 \\
\hline \multicolumn{8}{|c|}{ Neonatal care: parenteral feeding } & 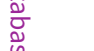 \\
\hline $\begin{array}{l}\text { Glutamine sup- } \\
\text { plementation } \\
\text { vs placebo to } \\
\text { prevent mor- } \\
\text { bidity and mor- } \\
\text { tality in preterm }\end{array}$ & $\begin{array}{l}\text { Neurodevelopmental impairment at } 2 \\
\text { years post term (defined as BSID-II MDI } \\
\leq 85, \mathrm{PDI} \leq 85 \text {, cerebral palsy, blind- } \\
\text { ness in } 1 \text { or both eyes, or hearing loss } \\
\text { requiring amplification) }\end{array}$ & $\begin{array}{l}375 \text { per } 1000 \\
(12 / 32)\end{array}$ & $\begin{array}{l}401 \text { per } 1000 \\
(221 \text { to } 720)\end{array}$ & $\begin{array}{l}\text { RR } 1.07(0.59 \\
\text { to } 1.92)\end{array}$ & $72(1 \mathrm{RCT})$ & LOW & $\begin{array}{l}\text { Imprecision (-2): "Total } \\
\text { sample size = } 72 " \\
\text { (graded by review au- } \\
\text { thors themselves) }\end{array}$ & 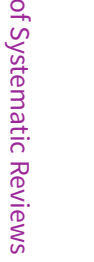 \\
\hline
\end{tabular}




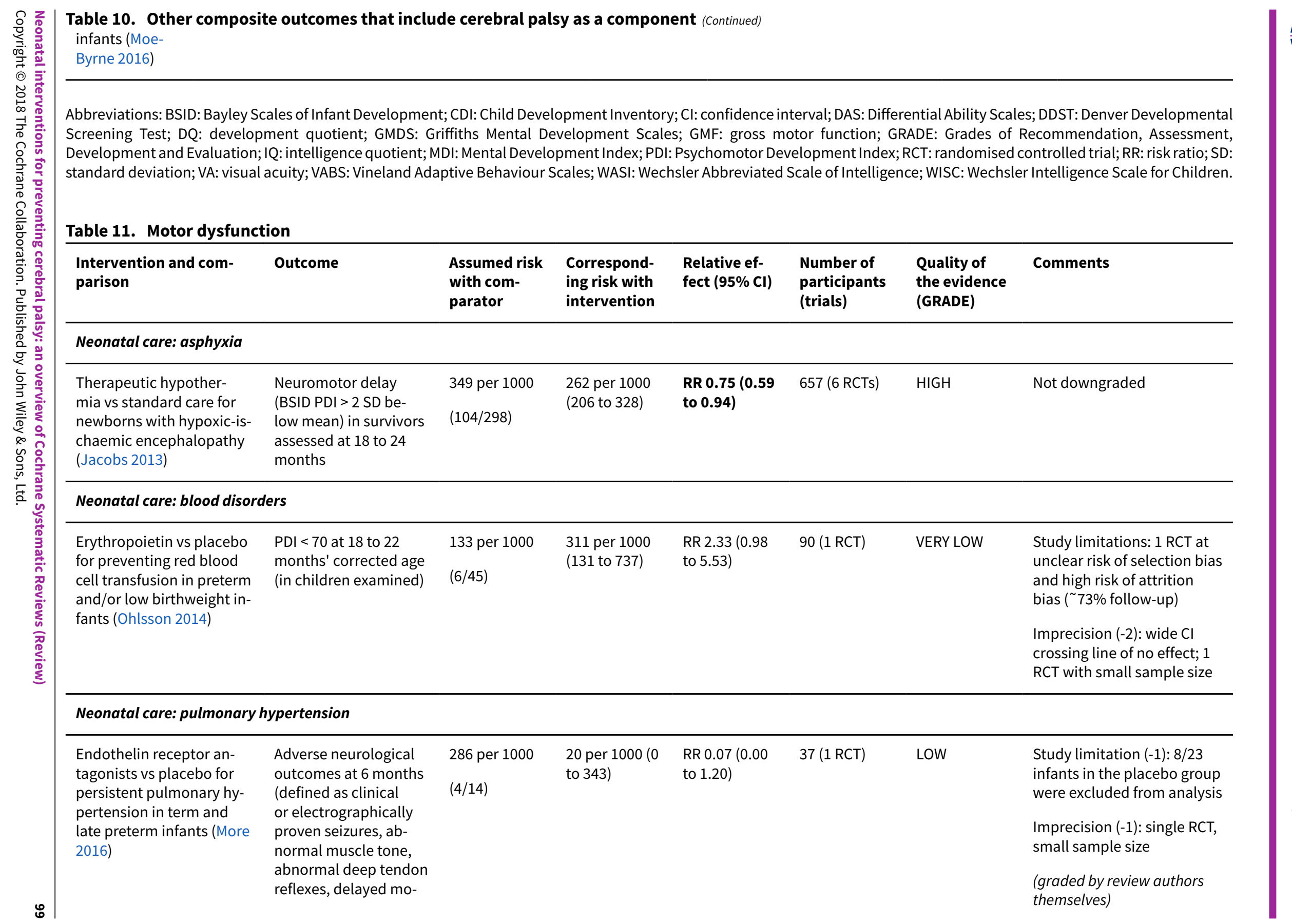




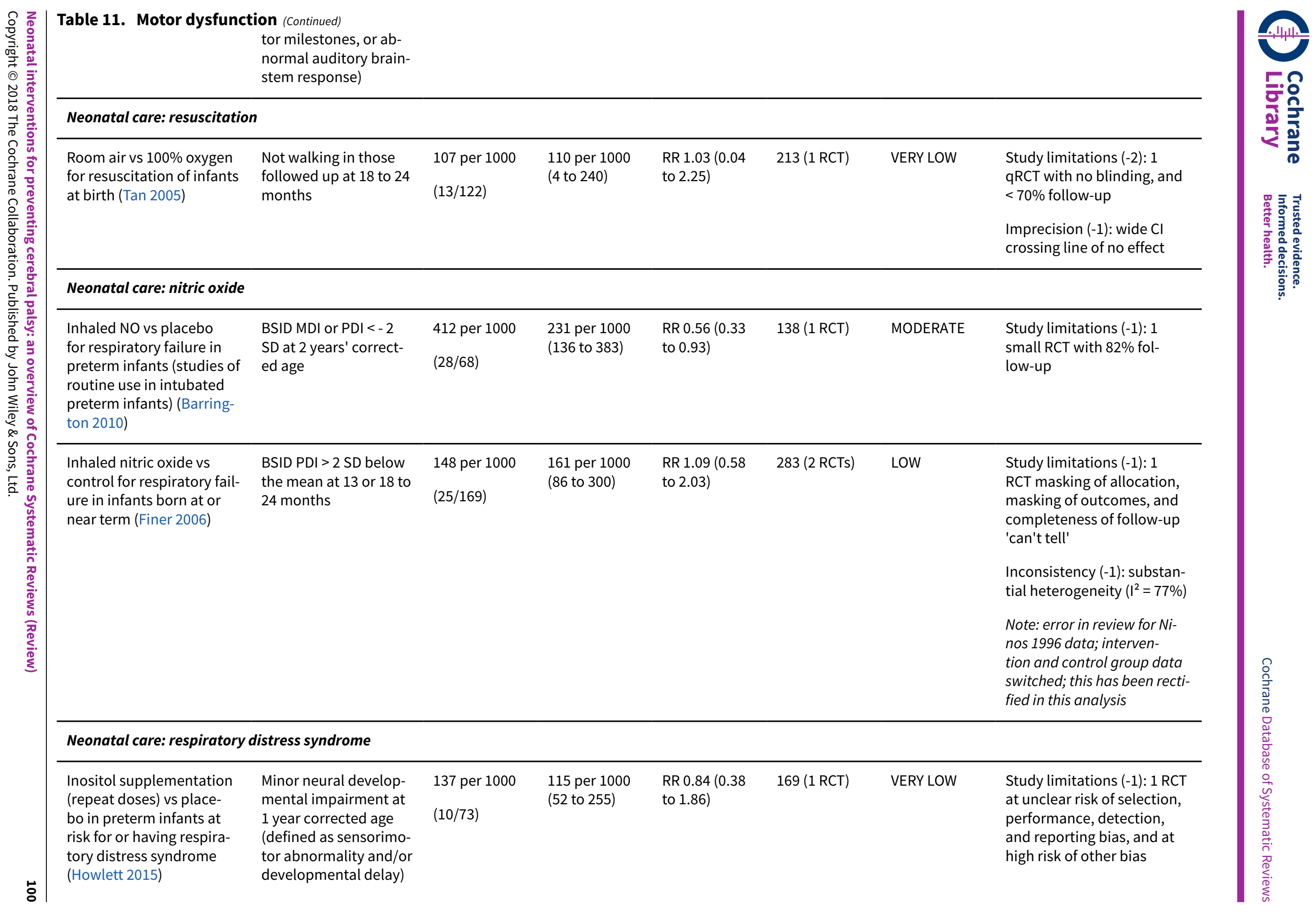




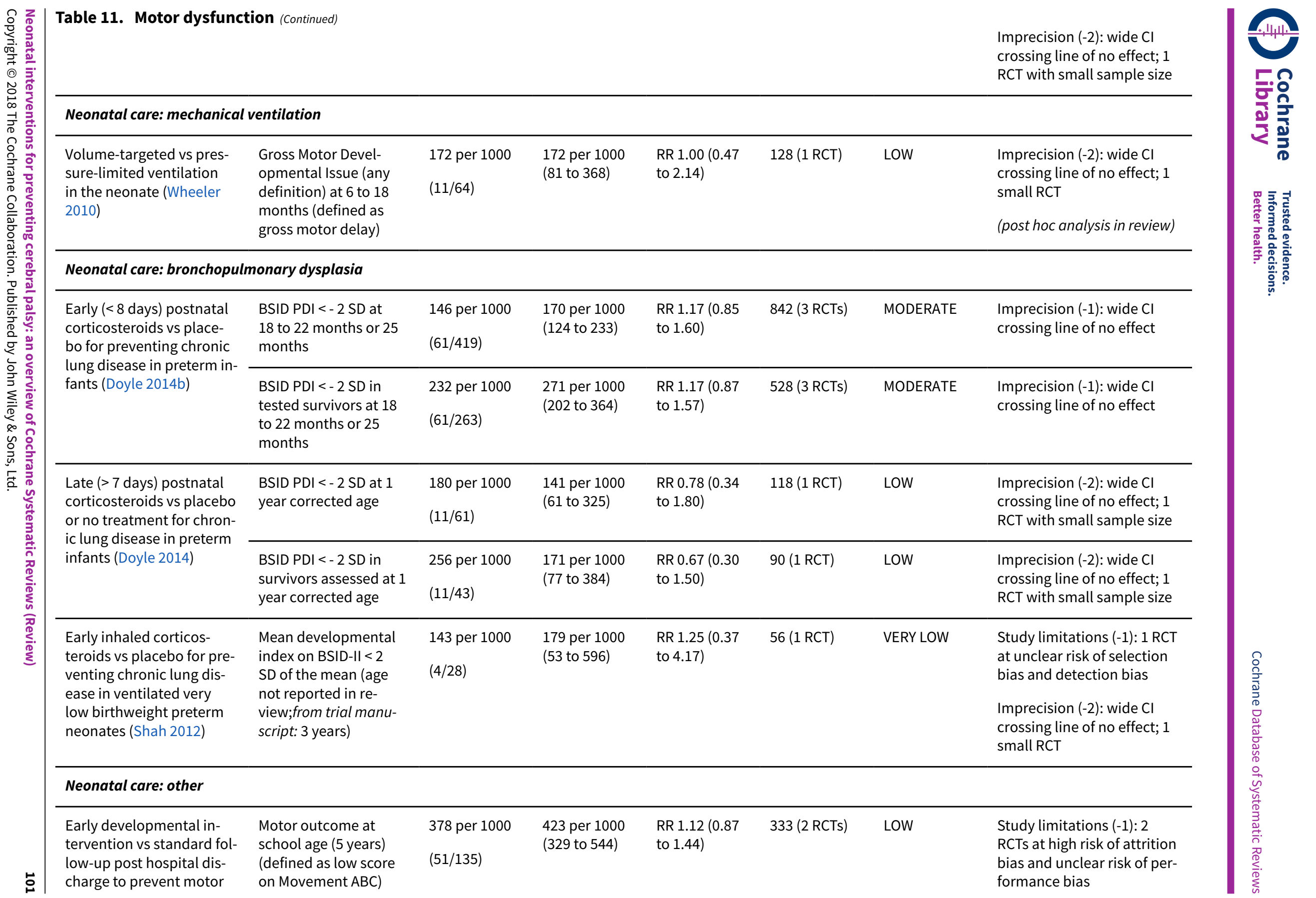




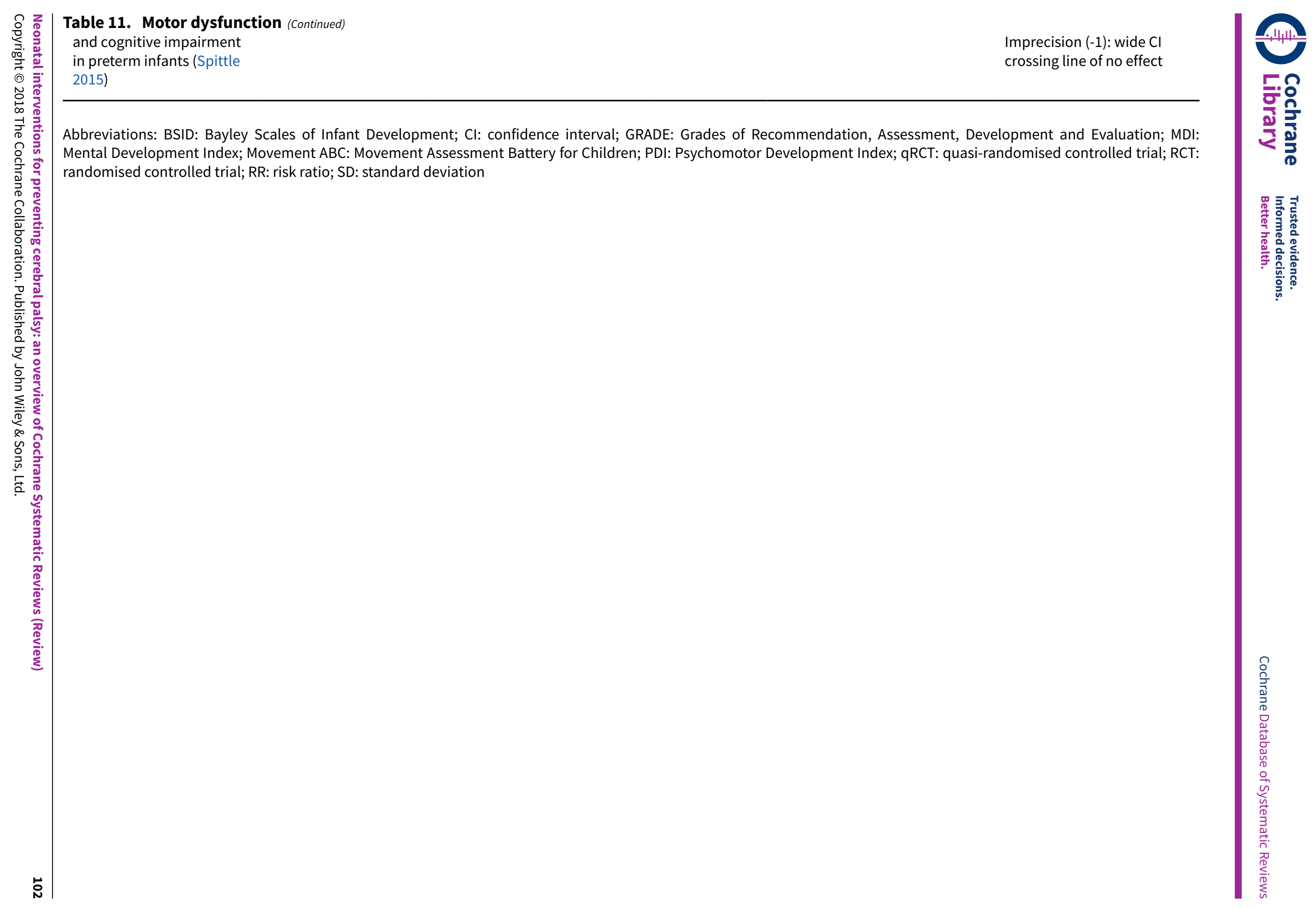




\section{APPENDICES}

\section{Appendix 1. Ongoing reviews}

\section{Protocol citation}

Abiramalatha T, Thomas N, Gupta V, Viswanathan A, McGuire W. High versus standard volumes of enteral feeds for preterm or low birth weight infants (Protocol). Cochrane Database of Systematic Reviews 2016, Issue 10.

\section{Overview outcomes pre-specified in protocol}

Secondary outcomes pre-specified include:

1. Neurodevelopmental outcomes assessed after 12 months post term: neurological evaluations; developmental scores; and classifications of disability, including auditory and visual disability. We will define neurodevelopmental impairment as the presence of 1 or more of the following: non-ambulant cerebral palsy; developmental quotient $>2$ SD below the population mean; and blindness (VA less than 6/60) or deafness (any hearing impairment requiring - or unimproved by - amplification)
Amari S, Shahrook S, Ota E, Mori R. Branched-chain amino acid supplementation for improving nutrition in term and preterm neonates (Protocol). Cochrane Database of Systematic Reviews 2016, Issue 7.

\section{Primary outcomes pre-specified include:}

1. Neurological development

a. Major neurodevelopmental disability after 18 months' post-term age

b. Cerebral palsy (yes/no)

c. Developmental delay ( $>2$ SD below the mean in a validated mental development test) or intellectual impairment (> 2 SD below the mean in a validated intelligence test) (yes/no)

d. Blindness (vision $<6 / 60$ in both eyes) (yes/no)

e. Sensorineural deafness (requiring amplification) (yes/no)
Askie LM, Darlow BA, Davis PG, Finer N, Stenson B, Vento M, Whyte R. Effects of targeting higher versus lower arterial oxygen saturations on death or disability in preterm infants (Protocol). Cochrane Database of Systematic Reviews 2014, Issue 7.

Primary outcomes pre-specified include:

1. Composite outcome of death or major disability by 18 to 24 months' corrected age (gestational age plus chronological age)

Secondary outcomes pre-specified include:

1. Major disability by 18 to 24 months' corrected age (gestational age plus chronological age)

2. Cerebral palsy with GMFCS level 2 or higher, or MACS level 2 or higher at 18 to 24 months' corrected age (gestational age plus chronological age)

Secondary outcomes pre-specified include:

Choo YM, Ahmad Kamar A, Tengku Kamalden TAF, Looi ML, Tan K, Lai NM. Lutein and zeaxanthin for reducing morbidity and mortality in preterm infants (Protocol). Cochrane Database of Systematic Reviews 2016, Issue 5.
1. Neurodevelopmental outcome assessed at 18 months to 28 months (Newman 2012). We will accept any of the following outcomes alone or in combination:cerebral palsy, mental retardation (BSID MDI $<70$ ), and hearing deficit (aided or $<60 \mathrm{~dB}$ on audiometric testing) or assessment via use of a validated cognitive/language/behavioural/social interaction/adaptive test (Albers 2007)
Dawson JA, Davis PG, Foster JP. Routine oro/nasopharyngeal suction versus no suction in the delivery room (Protocol). Cochrane Database of Systematic Reviews 2013, Issue 1.
Secondary outcomes pre-specified include:

1. Long-term neurodevelopmental outcome (rates ofcerebral palsy on physician assessment; developmental delay, i.e. DQ > 2 SD < the mean on validated assessment tools, e.g. BSID MDI)
Foster JP, Buckmaster A, Sinclair L, Lees S, Guaran R. Nasal continuous positive airway pressure (nCPAP) for term neonates with respiratory distress (Protocol). Cochrane Database of Systematic Reviews 2015, Issue 11.
Secondary outcomes pre-specified include:

1. Neurodevelopmental disability (after at least 18 months' postnatal age) defined as neurological abnormality including cerebral palsy on clinical examination, developmental delay $>2$ SD below population mean on a standardised test of development, blindness (VA $<6 / 60)$, or deafness (any hearing impairment requiring amplification) 
(Continued)

Foster JP, Taylor C, Bredemeyer SL. Topical anaesthesia for needle-related pain in newborn infants (Protocol). Cochrane Database of Systematic Reviews 2013, Issue 1.
Secondary outcomes pre-specified include:

1. Neurodevelopmental disability (after at least 18 months' postnatal age) defined as neurological abnormality including cerebral palsy on clinical examination, developmental delay $>2$ SD below population mean on a standardised test of development
Good M, Jones LJ, Osborn DA, Abdel-Latif ME. Transfusion of fresh versus non-fresh (older) red blood cell in neonates (Protocol). Cochrane Database of Systematic Reviews 2015, Issue 11.
Secondary outcomes pre-specified include:

1. Neurodevelopmental disability to at least 18 months' postnatal age (defined as neurological abnormality including cerebral palsy on clinical examination, developmental delay $>2$ SD below population mean on a standardised test of development, blindness (VA $<6 / 60$ ), or deafness (any hearing impairment requiring amplification) at any time after term corrected)
Gordon A, Greenhalgh M, McGuire W. Early planned removal versus expectant management of peripherally inserted central catheters to prevent infection in newborn infants (Protocol). Cochrane Database of Systematic Reviews 2016, Issue 4.
Secondary outcomes pre-specified include:

1. Neurodevelopmental outcomes assessed after 12 months post term using validated tools: neurological evaluations; developmental scores; and classifications of disability, including auditory and visual disability. We will define neurodevelopmental impairment as the presence of 1 or more of the following: non-ambulant cerebral palsy; DQ > 2 SD below the population mean; and blindness $(V A<6 / 60)$ or deafness (any hearing impairment requiring or unimproved by amplification)

2. Death or neurological impairment assessed after 12 months post term
Gordon A, Greenhalgh M, McGuire W. Early planned removal of umbilical venous catheters to prevent infection in newborn infants (Protocol). Cochrane Database of Systematic Reviews 2016, Issue 4.
Secondary outcomes pre-specified include:

1. Neurodevelopmental outcomes assessed after 12 months post term using validated tools: neurological evaluations; developmental scores; and classifications of disability, including auditory and visual disability. We will define neurodevelopmental impairment as the presence of 1 or more of the following: non-ambulant cerebral palsy; $\mathrm{DQ}>2 \mathrm{SD}$ below the population mean; and blindness $(\mathrm{VA}<6 / 60)$ or deafness (any hearing impairment requiring or unimproved by amplification)

2. Death or neurological impairment assessed after 12 months post term
Green DS, Abdel-Latif ME, Jones LJ, Osborn DA. Pharmacological interventions for prevention and treatment of upper gastrointestinal bleeding in newborn infants (Protocol). Cochrane Database of Systematic Reviews 2015, Issue 7.

\section{Secondary outcomes pre-specified include:}

1. Neurodevelopmental disability (defined as neurological abnormality including cerebral palsy on clinical examination or global developmental delay (2 or more SD below population mean on BSID or GMDS at any time after term corrected at 1 year, 18 months', 2 years', and 5 years' postnatal age)
Han S, Yu Z, Guo X, Dong X, Chen X, Soll R. Intratracheal instillation of corticosteroids using surfactant as a vehicle for the prevention of chronic lung disease in preterm infants with respiratory distress syndrome (Protocol). Cochrane Database of Systematic Reviews 2011, Issue 4
Secondary outcomes pre-specified include:

1. Neurodevelopmental outcome at a later time point ( $>1$ year post-conceptional age). Neurodevelopmental impairment is defined as the presence of cerebral palsy and/or mental retardation (BSID MDI < 70) and/or legal blindness (<20/200 VA) and or deafness (aided or $<60 \mathrm{~dB}$ on audiometric testing)
Hegarty JE, Harding JE, Crowther CA, Brown J, Alsweiler J. Oral dextrose gel for the prevention of hypoglycaemia in newborn infants (Protocol). Cochrane Database of Systematic Reviews 2016, Issue 4.

\section{Primary outcomes pre-specified include:}

1. Major neurological disability at 2 years of age or greater (any of legal blindness, sensorineural deafness requiring hearing aids, moderate or severe cerebral palsy, or developmental delay/intellectual impairment (defined as a DQ or IQ lower than 2 SD below the mean))

Secondary outcomes pre-specified include:

1. Cerebral palsy and severity at 2 years of age or older 
(Continued)

Hyttel-Sorensen S, Støy Saem L, Greisen G, Als-Nielsen B, Gluud C. Cerebral near-infrared spectroscopy monitoring for prevention of brain injury in very preterm infants (Protocol). Cochrane Database of Systematic Reviews 2015, Issue 2.
Primary outcomes pre-specified include:

1. Major neurodevelopmental disability:

\section{a. Cerebral palsy}

b. Developmental delay or intellectual impairment:

i. BSID or GMDS assessment $>2$ SD below the mean or intellectual impairment (IQ > 2 SD below mean)

ii. Neuromotor development (BSID - PDI) assessed in survivors

iii. Mental development (BSID - MDI) assessed in survivors

C. Blindness (vision <6/60 in both eyes)
Jauncey-Cooke J, Bogossian F, Hough JL, Schibler A, Davies MW, Grant CA, Gibbons $\mathrm{K}$, East $\mathrm{CE}$. Lung recruitment manoeuvres for reducing respiratory morbidity in mechanically ventilated neonates (Protocol). Cochrane Database of Systematic Reviews 2012, Issue 7.
Secondary outcomes pre-specified include:

1. Neurodevelopmental impairment: cerebral palsy, sensorineural hearing loss, visual impairment or developmental delay (e.g. GMDS, BSID) assessed at 12 to 24 months' corrected age, 2 years, or 5 years
Kaempfen S, Neumann RP, Jost K, Schulzke $\mathrm{SM}$. Beta-blockers for prevention and treatment of retinopathy of prematurity in preterm infants (Protocol). Cochrane Database of Systematic Reviews 2015, Issue 9.
Secondary outcomes pre-specified include:

1. Adverse neurodevelopmental outcomes at 18 to 24 months' corrected age a. Cerebral palsy

b. Moderate to severe developmental delay as assessed by validated neurodevelopmental tests such as BSID
Kent A, Kecskes Z. Magnesium sulfate for term infants following perinatal asphyxia (Protocol). Cochrane Database of Systematic Reviews 2003, Issue 2.
Primary outcomes pre-specified include:

1. Severe neurodevelopmental disability at or equal to 12 months of age or more. Severe neurodevelopmental disability is defined as cerebral palsy, developmental delay (DQ $<70$ ), or blindness (VA $<6 / 60$ in both eyes), or any combination of these disabilities
Kulasekaran K, Sargent PH, Flenady V. Milrinone for the treatment of cardiac dysfunction in neonates (Protocol). Cochrane Database of Systematic Reviews 2004, Issue 4.

\section{Secondary outcomes pre-specified include:}

1. Neurodevelopmental outcome (neurodevelopmental outcome assessed by a standardised and validated assessment tool and/or a child developmental specialist) at any age reported (outcome data will be grouped at 12, 18, 24 months if available) cerebral palsy, developmental delay, blindness, sensorineural deafness
Lai NM, Ahmad Kamar A, Choo YM, Kong JY, Ngim CF. Fluid supplementation for neonatal unconjugated hyperbilirubinaemia (Protocol). Cochrane Database of Systematic Reviews 2015, Issue 9.

\section{Primary outcomes pre-specified include:}

1. Proportion of infants with moderate or severe cerebral palsy, defined as a non-progressive disorder with abnormal muscle tone in at least $1 \mathrm{arm}$ or leg that was associated with abnormal control of movement or posture and a modified GMFCS score (Palisano 2008) $\geq 2$ (Rosenbaum 2007), measured at predefined intervals, e.g. at 6, 12, 18 , and 24 months

Secondary outcomes pre-specified include:

1. Proportion of infants with motor impairment, as indicated by a score of 2 or higher in the modified GMFCS evaluation (Palisano 2008)
Lui K, Foster JP, Davis PG, Ching SK, Oei

$\mathrm{JL}$, Osborn DA. Higher versus lower oxygen
Primary outcomes pre-specified include: 
(Continued)

concentrations titrated to target oxygen saturations during resuscitation of preterm infants at birth (Protocol). Cochrane Database of Systematic Reviews 2012, Issue 11.
1. Neurodevelopmental disability (after $>18$ months' postnatal age):

a. Neurological abnormality including cerebral palsy on clinical examination, developmental delay $>2$ SD below population mean on any standard test of development

b. Blindness $(V A<6 / 60)$

c. Deafness (any hearing impairment requiring amplification)
Malhotra A, Veldman A. Recombinant activated Factor VII for prevention and treatment of intraventricular haemorrhage in neonates (Protocol). Cochrane Database of Systematic Reviews 2011, Issue 3.
Primary outcomes pre-specified include:

1. Severe neurodevelopmental disability as defined by cerebral palsy, low developmental scores ( $D Q<2$ SD or untestable), blindness, or any combination of these using validated assessment tools at 18 or 24 months: neurological examinations, developmental scores (BSID, etc.)
McCarthy LK, Davis PG, O'Donnell CPF. Nasal airways (single or double prong, long or short) for neonatal resuscitation (Protocol). Cochrane Database of Systematic Reviews 2011, Issue 5.
Secondary outcomes pre-specified include:

1. Long-term neurodevelopmental outcome (rates of cerebral palsy on physician assessment; developmental delay, i.e. DQ $>2$ SD < the mean on validated assessment tools, e.g. BSID MDI)
Molloy EJ, McCallion N, O'Donnell CPF, Davis PG. Heliox for prevention of morbidity and mortality in ventilated newborn infants (Protocol). Cochrane Database of Systematic Reviews 2008, Issue 3.
Secondary outcomes pre-specified include:

1. Death or long-term ( $<18$ months) major neurodevelopmental disability (cerebral palsy, developmental delay (BSID or GMDS assessment $>2$ SD below the mean) or intellectual impairment (IQ > 2 SD below mean), blindness (vision $<6 / 60$ in both eyes), sensorineural deafness requiring amplification)
Neary E, Ni Ainle F, El-Khuffash A, Cotter M, Kirkham C, McCallion N. Plasma transfusion to prevent intraventricular haemorrhage in very preterm infants (Protocol). Cochrane Database of Systematic Reviews 2016, Issue 9.
Primary outcomes pre-specified include:

1. Neurodevelopmental disability at 2 years' postnatal age, defined as neurological abnormality on clinical examination, including cerebral palsy, developmental delay > 2 SD below the population mean on any standard test of development, blindness (VA $<6 / 60$ ), or deafness (any hearing impairment requiring amplification) at any time after 2 years' corrected age
O'Donnell CPF, Davis PG, Morley CJ. Endotracheal intubation versus face mask for newborns resuscitated with positive pressure ventilation at birth (Protocol). Cochrane Database of Systematic Reviews 2004, Issue 4.
Secondary outcomes pre-specified include:

1. Long-term neurodevelopmental outcome (rates ofcerebral palsy on physician assessment, developmental delay, i.e. IQ 2 SD < the mean on validated assessment tools, e.g. BSID MDI)
O'Donnell CPF, Davis PG, Morley CJ. Manual ventilation devices for neonatal resuscitation (Protocol). Cochrane Database of Systematic Reviews 2004, Issue 3.
Secondary outcomes pre-specified include:

1. Long-term neurodevelopmental outcome (rates of cerebral palsy on physician assessment, developmental delay, i.e. IQ 2 SD < the mean on validated assessment tools, e.g. BSID MDI)
Onland W, De Jaegere APMC, Offringa M, van Kaam A. Systemic corticosteroid regimens for prevention of bronchopulmonary dysplasia in preterm infants (Protocol). Cochrane Database of Systematic Reviews 2014, Issue 1.
Secondary outcomes pre-specified include:

1. Long-term neurodevelopmental sequelae, assessed after at least 1 year corrected gestational age and before a corrected gestational age of 4 years, and at the latest reported time point, including cerebral palsy and BSID (MDI)
Onyango $A B$, Suresh G, Were F. Intermittent phototherapy versus continuous phototherapy for neonatal jaundice (Protocol). Cochrane Database of Systematic Reviews 2009, Issue 4.
Primary outcomes pre-specified include:

1. Kernicterus defined as either the pathological finding of deep-yellow staining of neurons and neuronal necrosis of the basal ganglia and brainstem nuclei or acute or chronic neurological deficit including athetoid cerebral palsy, impaired upward gaze 
Pierro M, Thébaud B, Soll R. Mesenchymal stem cells for the prevention and treatment of bronchopulmonary dysplasia in preterm infants (Protocol). Cochrane Database of Systematic Reviews 2015, Issue 11.
Secondary outcomes pre-specified include:

1. Cerebral palsy at 18 to 24 months' corrected age

2. Neurodevelopmental outcome at approximately 2 years' corrected age (acceptable range 18 months to 28 months) including cerebral palsy, delayed neurodevelopment (BSID MDI < 70), legal blindness ( $<20 / 200 \mathrm{VA}$ ), and hearing deficit (aided or $<60 \mathrm{~dB}$ on audiometric testing). We will define the composite outcome 'neurodevelopmental impairment' as having any 1 of the aforementioned deficits
Rivas-Fernandez M, Roqué i Figuls M, Tobias A, Balaguer A. Different strains of probiotics for preventing morbidity and mortality in preterm infants: a network metaanalysis (Protocol). Cochrane Database of Systematic Reviews 2016, Issue 8.
Secondary outcomes pre-specified include:

1. Neurodevelopment impairment (i.e. rates of cerebral palsy, cognitive delay, deafness, blindness or their composite reported at 18 months' corrected age or later)
Romantsik O, Calevo MG, Bruschettini M. Head midline position for preventing the occurrence or extension of germinal matrix-intraventricular hemorrhage in preterm infants (Protocol). Cochrane Database of Systematic Reviews 2016, Issue 9.

Secondary outcomes pre-specified include:

1. Long-term neurodevelopmental outcomes (yes/no): cerebral palsy on physician assessment, developmental delay (i.e. IQ 2 SD below the mean on validated assessment tools such as BSID MDI) (Bayley 1993; Bayley 2006)

2. Major neurodevelopmental disability: cerebral palsy, developmental delay (BSID MDI (Bayley 1993; Bayley 2006) or GMDS (Griffiths 1954) assessment $>2$ SDs below the mean), intellectual impairment (IQ $>2$ SDs below the mean), blindness (vision $<6 / 60$ in both eyes), or sensorineural deafness requiring amplification (Jacobs 2013). We plan to evaluate each of these components as a separate outcome and to extract data on each long-term outcome from studies that evaluated children after 18 months' chronological age. We will separately assess data on children 18 to 24 months of age and on those 3 to 5 years of age

Secondary outcomes pre-specified include:

Seliem W, Bhutta ZA, Soll R, McGuire W. Topical emollient therapy for preventing infection in preterm infants in low- or middle-income countries (Protocol). Cochrane Database of Systematic Reviews 2007, Issue 3.
1. Neurodevelopmental outcomes at $>12$ months post term (measured using validated assessment tools) and classifications of disability, including auditory and visual disability. The composite outcome "severe neurodevelopmental disability" will be defined as any 1 or combination of the following: non-ambulant cerebral palsy, severe developmental delay, auditory and visual impairment
Shah D, Tracy M. Cutaneous antisepsis for prevention of intravascular catheter-associated infection in newborn infants (Protocol). Cochrane Database of Systematic Reviews 2014, Issue 3.
Secondary outcomes pre-specified include:

1. Long-term neurodevelopmental outcome: neurodevelopmental outcome at approximately 2 years' corrected age (acceptable range 18 months to 28 months) including cerebral palsy, significant mental developmental delay (BSID MDI $<70$ ), legal blindness ( $<20 / 200 \mathrm{VA})$, and hearing deficit (aided or $<60 \mathrm{~dB}$ on audiometric testing). The composite outcome "neurodevelopmental impairment" was defined as having any 1 of the aforementioned deficits

Primary outcomes pre-specified include:

1. Neurodevelopmental disability at at least 18 months' postnatal age (defined as neurological abnormality including cerebral palsy on clinical examination, developmental delay $>2$ SD below population mean on a standardised test of development, blindness (VA $<6 / 60)$, or deafness (any hearing impairment requiring amplification) at any time after term corrected)

Secondary outcomes pre-specified include: 
1. Individual components of neurodevelopment at at least 18 months' postnatal age:

a. Cerebral palsy on clinical examination

b. Developmental delay $>2$ SD below population mean on a standardised test of development

c. Blindness $(\mathrm{VA}<6 / 60)$

d. Deafness (any hearing impairment requiring amplification) at any time after term corrected

Van Rostenberghe H, Ho JJ, Quah BS, Noraida $\mathrm{R}$. The effects of thyroxine on end organ damage in asphyxiated neonates (Protocol). Cochrane Database of Systematic Reviews 2009, Issue 4.
Primary outcomes pre-specified include:

1. Any neurodevelopmental disability assessed at 12 months or more of age:

a. Presence of no/minor or major disabilities

b. Presence ofcerebral palsy

c. Any objective quantitative assessments of neurodevelopmental assessment that are internationally recognised
Xiong T, Chen H, Mu D. Effect of pre-exchange albumin infusion on neonatal hyperbilirubinaemia and long-term developmental outcomes (Protocol). Cochrane Database of Systematic Reviews 2014, Issue 2.
Primary outcomes pre-specified include:

1. Neurological deficits consistent with kernicterus at 2 years of age (including separate analysis of each component): athetoid cerebral palsy, impaired upward gaze and deafness, auditory neuropathy or dys-synchrony (ABR abnormality), dental dysplasia, and subtle bilirubin-induced neurological dysfunction
Xiong T, Li H, Zhao J, Dong W, Qu Y, Wu T, $\mathrm{Mu}$ D. Hyperbaric oxygen for term newborns with hypoxic ischemic encephalopathy (Protocol). Cochrane Database of Systematic Reviews 2011, Issue 8.
Primary outcomes pre-specified include:

1. Long-term (> 18 months) major neurodevelopmental disabilities among all participants or survivors (cerebral palsy, developmental delay (BSID or GMDS assessment $>2$ SD below the mean), or intellectual impairment (IQ $>2$ SD below mean), blindness (vision $<6 / 60$ in both eyes), sensorineural deafness requiring amplification)
Yu B, Li S, Zhou D, Davis PG. Subcutaneous reservoir drainage versus ventriculoperitoneal shunt for the treatment of posthemorrhagic hydrocephalus in preterm infants (Protocol). Cochrane Database of Systematic Reviews 2009, Issue 3.
Primary outcomes pre-specified include:

1. The incidence rates of death or neurodevelopmental disability in infancy $(>12$ months' postnatal age). Neurodevelopmental disability includes developmental delay (e.g. the score of BSID < 2 SD below the mean indicates developmental delay), cerebral palsy, blindness, deafness, and any other neurodevelopmental abnormalities
Yu Z, Guo X, Han S, Lu J, Sun Q. Erythropoietin for term and late preterm infants with hypoxic ischemic encephalopathy (Protocol). Cochrane Database of Systematic Reviews 2010, Issue 1 .
Primary outcomes pre-specified include:

1. The primary outcome measure will be either death or long-term (1 year or 18 months) major neurodevelopmental disability (cerebral palsy, developmental delay (BDIS or GMDS assessment $>2$ SD below the mean), or intellectual impairment (IQ $>2$ SD below mean), blindness (vision $<6 / 60$ in both eyes), sensorineural deafness requiring amplification)

Secondary outcomes pre-specified include:

1. Each component of the primary outcome:
a. Cerebral palsy
b. Developmental delay or intellectual impairment
c. Blindness
d. Sensorineural deafness requiring amplification patient

Yu Z, Sun Q, Han S, Lu J, Ohlsson A, Guo X. Erythropoietin for preterm infants with hypoxic ischaemic encephalopathy (Protocol). Cochrane Database of Systematic Reviews 2012, Issue 12.

\section{Primary outcomes pre-specified include:}

1. Either death (at 28 days and at discharge) or long-term (1 year or 24 months' corrected age) intellectual impairment (IQ $>2$ SD below mean), blindness (vision $<6 / 60$ in both eyes), sensorineural deafness requiring amplification 
1. Each component of the primary outcome:

a. Death at 28 days and at discharge

b. Cerebral palsy at $>1$ year (the criterion for the diagnosis of cerebral palsy was a fixed motor deficit diagnosed by a neurologist)

c. Developmental delay (BSID or GMDS $>2$ SD below the mean) or intellectual impairment (IQ > 2 SD below mean) at 1 year or 24 months' corrected age

d. Blindness (vision $<6 / 60$ in both eyes) at 1 year or 24 months' corrected age

e. Sensorineural deafness requiring amplification patient at 1 year or 24 months' corrected age

Abbreviations: ABR: auditory brainstem response; BSID: Bayley Scales of Infant Development; DQ: developmental quotient; GMDS: Griffith Mental Development Scales; GMFCS: Gross Motor Function Classification System; IQ; intelligence quotient; MACS: Manual Ability Classification System; MDI: Mental Development Index; PDI: Psychomotor Development Index; SD: standard deviation; VA: visual acuity

\section{Appendix 2. Reviews awaiting further classification}

\begin{tabular}{|c|c|}
\hline Revie & $\begin{array}{l}\text { Overview outcomes pre-specified in re- } \\
\text { view with no outcome data }\end{array}$ \\
\hline Abdel-Latif ME, Osborn & Primary outcomes pre-specified include: \\
\hline $\begin{array}{l}\text { DA. Intratracheal Clara } \\
\text { cell secretory protein } \\
\text { (CCSP) administration } \\
\text { in preterm infants with } \\
\text { or at risk of respirato- } \\
\text { ry distress syndrome. } \\
\text { Cochrane Database of } \\
\text { Systematic Reviews } \\
\text { 2011, Issue 5. }\end{array}$ & $\begin{array}{l}\text { 1. Neurodevelopmental disability } \geq 18 \\
\text { months' postnatal age (defined as neu- } \\
\text { rological abnormality including cerebral } \\
\text { palsy on clinical examination, develop- } \\
\text { mental delay }>2 \text { SD below population } \\
\text { mean on a standardised test of develop- } \\
\text { ment, blindness (VA }<6 / 60 \text { ), or deafness } \\
\text { (any hearing impairment requiring ampli- } \\
\text { fication) at any time after term corrected) }\end{array}$ \\
\hline
\end{tabular}

Abdel-Latif ME, Osborn DA. Laryngeal mask airway surfactant administration for prevention of morbidity and mortality in preterm infants with or at risk of respiratory distress syndrome. Cochrane Database of Systematic Reviews 2011, Issue 7 .

\section{Primary outcomes pre-specified include:}

1. Neurodevelopmental disability $\geq 18$ months' postnatal age (defined as neurological abnormality including cerebral palsy on clinical examination, developmental delay $>2$ SD below population mean on a standardised test of development, blindness (VA $<6 / 60$ ), or deafness (any hearing impairment requiring amplification) at any time after term corrected)

\section{Main conclusion(s) of review}

"There are insufficient data to determine the role of rhCC10 in clinical practice. Further studies are required to determine if rhCC10 reduces lung inflammation in infants at risk of CLD, and to determine dose and dosing strategy"

\footnotetext{
Abdel-Latif ME, Osborn DA. Pharyngeal instillation of surfactant before the first breath for prevention of morbidity and mortality in preterm infants at risk of respiratory distress syndrome. Cochrane Database of Systematic Reviews 2011, Issue 3.
}

\section{Primary outcomes pre-specified include:}

1. Neurodevelopmental disability at $\geq 18$ months' postnatal age, defined as neurological abnormality including cerebral palsy on clinical examination, developmental delay of $>2$ SD below the population mean on a standardised test of development, blindness $(V A<6 / 60)$, or deafness (any hearing impairment requiring ampli-
"There is evidence from a single small trial that LMA surfactant administration in preterm infants $\geq 1200 \mathrm{~g}$ with established RDS may have a short term effect in reducing oxygen requirements although the study is underpowered to detect important clinical effects. Adequately powered trials are required to determine the effect of LMA surfactant administration for prevention or treatment of RDS in preterm infants. LMA surfactant administration should be limited to clinical trials"

No included trials.

"There were no data from randomised controlled or quasi-randomised trials that evaluated the effect of intrapartum instillation of pharyngeal surfactant before the first breath. Evidence from animal and observational human studies suggest that pharyngeal instillation of surfactant before the first breath is potentially safe, feasible and may be effective. Well designed trials are needed" 


\section{Abdel-Latif ME, Osborn} DA. Nebulised surfactant in preterm infants with or at risk of respiratory distress syndrome. Cochrane Database of Systematic Reviews 2012, Issue 10.
Primary outcomes pre-specified include:

1. Neurodevelopmental disability assessed at 18 months' postnatal age or later defined as neurological abnormality including cerebral palsy on clinical examination, developmental delay $>2$ SD below population mean on a standardised test of development, blindness (VA $<6 / 60$ ), or deafness (any hearing impairment requiring amplification) at any time after term corrected
"There are insufficient data to support or refute the use of nebulised surfactant in clinical practice. Adequately powered trials are required to determine the effect of nebulised surfactant administration for prevention or early treatment of RDS in preterm infants. Nebulised surfactant administration should be limited to clinical trials"

\begin{abstract}
Ainsworth S, McGuire W. Percutaneous central venous catheters versus peripheral cannulae for delivery of parenteral nutrition in neonates. Cochrane Database of Systematic Reviews 2015, Issue 10.
\end{abstract}

Primary outcomes pre-specified include:

1. Neurodevelopmental outcomes during infancy and beyond, using validated assessment tools, such as BSID, and classifications of disability, including auditory and visual disability. Severe neurodevelopmental disability was defined as any one or combination of the following: nonambulant cerebral palsy, developmental delay ( $\mathrm{DQ}<70)$, or auditory and visual impairment

Outcomes pre-specified include:

1. Incidence ofcerebral palsy.
"Data from one small trial suggest that use of percutaneous central venous catheters to deliver parenteral nutrition increases nutrient input. The significance of this in relation to long-term growth and developmental outcomes is unclear. Three trials suggest that use of percutaneous central venous catheters decreases the number of catheters/cannulae needed to deliver nutrition. No evidence suggests that percutaneous central venous catheter use increases risks of adverse events, particularly invasive infection, although none of the included trials was large enough to rule out an effect on uncommon severe adverse events such as pericardial effusion"

\author{
Alcock GS, Liley H. Im- \\ munoglobulin infu- \\ sion for isoimmune \\ haemolytic jaundice \\ in neonates. Cochrane \\ Database of Systematic \\ Reviews 2002, Issue 3.
}

\begin{abstract}
"Although the results show a significant reduction in the need for exchange transfusion in those treated with intravenous immunoglobulin, the applicability of the results is limited. The number of studies and infants included is small and none of the three included studies was of high quality. The protocols of two of the studies mandated the use of early exchange transfusion, limiting the generalizability of the results. Further well designed studies are needed before routine use of intravenous immunoglobulin can be recommended for the treatment of isoimmune haemolytic jaundice"
\end{abstract}

\footnotetext{
Anabrees J, AlFaleh $\mathrm{K}$. Fluid restriction and prophylactic indomethacin versus prophylactic indomethacin alone for prevention of morbidity and mortality in extremely low birth weight infants. Cochrane Database of Systematic Reviews 2011, Issue 7.
}

Secondary outcomes pre-specified include:

1. Neurosensory impairment defined as rates of cerebral palsy, cognitive delay, deafness, blindness at 18 to 24 months' corrected age as per BSID score (Bayley 1993)

2. The composite of death or neurosensory impairment at 18 to 24 months' corrected age

\section{No included trials}

"We found no randomized controlled trials to investigate the possible interaction between fluid restriction and indomethacin prophylaxis versus indomethacin prophylaxis alone in ELBW infants. A well-designed randomized trial is needed to address this question"
Austin N, Cleminson J, Darlow BA, McGuire W. Prophylactic oral/topical non-absorbed antifungal agents to prevent invasive fungal
Primary outcomes pre-specified include:

1. Neurodevelopmental outcomes assessed beyond infancy (neurological evaluations, developmental scores, and classifications of disability, including auditory and visual
"The finding of a reduction in risk of invasive fungal infection in very low birth weight infants treated with oral/topical non-absorbed antifungal prophylaxis should be interpreted cautiously because of methodological weaknesses in the included trials. Further large randomised controlled trials in current neonatal practice settings are needed to 
(Continued)

infection in very low birth weight infants. Cochrane Database of Systematic Reviews 2015, Issue 10. disability, non-ambulant cerebral palsy, developmental delay); and cognitive and educational outcomes at 5 years or older (IQ and/or indices of educational achievement measured using a validated tool including school examination results) resolve this uncertainty. These trials might compare oral/ topical non-absorbed antifungal agents with placebo, with each other, or with systemic antifungal agents and should include an assessment of effect on long-term neurodevelopmental outcomes"

\begin{abstract}
Bahadue FL, Soll R. Early versus delayed selective surfactant treatment for neonatal respiratory distress syndrome. Cochrane Database of Systematic Reviews 2012, Issue 11.
\end{abstract}

Secondary outcomes pre-specified include:

\section{Cerebral palsy}

2. Neurodevelopmental outcome at approximately 2 years' corrected age (acceptable range 18 months to 28 months) including cerebral palsy, mental retardation (BSID MDI < 70), legal blindness (<20/200 VA), and hearing deficit (aided or $<60 \mathrm{~dB}$ on audiometric testing). The composite outcome "neurodevelopmental impairment" will be defined as having any 1 of the aforementioned deficits
Rivas-Fernandez M, Roqué i Figuls M, DiezIzquierdo A, Escribano J, Balaguer A. Infant position in neonates receiving mechanical ventilation. Cochrane Database of Systematic Reviews 2016, Issue 11.
Secondary outcomes pre-specified include:

1. Long-term neurodevelopmental outcomes at age 2 years: rates of cerebral palsy as assessed by physician, developmental delay (i.e. $\mathrm{IQ}<2 \mathrm{SD}$ ) on validated assessment tools (e.g. the S-B Intelligence Scale or others), or sensory impairment
"Early selective surfactant administration given to infants with RDS requiring assisted ventilation leads to a decreased risk of acute pulmonary injury (decreased risk of pneumothorax and pulmonary interstitial emphysema) and a decreased risk of neonatal mortality and chronic lung disease compared to delaying treatment of such infants until they develop worsening RDS"
Balain M, Oddie SJ, McGuire W. Antimicrobial-impregnated central venous catheters for prevention of catheter-related bloodstream infection in newborn infants. Cochrane Database of Systematic Reviews 2015, Issue 9.
Secondary outcomes pre-specified include:

1. Neurodevelopmental outcomes assessed $>12$ months' corrected age using validated tools: neurological evaluations; developmental scores; and classifications of disability, including auditory and visual disability. We will define neurodevelopmental impairment as the presence of 1 or more of the following: non-ambulant cerebral palsy; DQ > 2 SD below the population mean; and blindness (VA $<6 / 60)$ or deafness (any hearing impairment requiring or unimproved by amplification)

2. Death or neurological impairment assessed > 12 months' corrected age
"This update of our last review in 2013 supports previous conclusions. Evidence of low to moderate quality favours the prone position for slightly improved oxygenation in neonates undergoing mechanical ventilation. However, we found no evidence to suggest that particular body positions during mechanical ventilation of the neonate are effective in producing sustained and clinically relevant improvement"

\section{"Although the data from one small trial indicates that} antimicrobial-impregnated central venous catheters might prevent catheter-related bloodstream infection in newborn infants, the available evidence is insufficient to guide clinical practice. A large, simple and pragmatic randomised controlled trial is needed to resolve on-going uncertainty"

\footnotetext{
Bassler D, Kreutzer K, McNamara P, Kirpalani H. Milrinone for persistent pulmonary hypertension of the newborn. Cochrane Database of Systematic Reviews 2010, Issue 11.
}

\section{Primary outcomes pre-specified include:}

1. Neurodevelopment (assessed by the presence of cerebral palsy, cognitive delay, blindness or deafness, and the BSID-II) assessed $>18$ months of life
"The efficacy and safety of milrinone in the treatment of PPHN are not known and its use should be restricted within the context of RCTs. Such studies should address a comparison of milrinone with placebo (in clinical situations where iNO is not available) or, in well resourced countries, should compare milrinone with iNO or as an adjunct to iNO compared with iNO alone"
Basuki F, Hadiati DR, Turner T, McDonald S,
Secondary outcomes pre-specified include:

"There is evidence from three small, old trials at unclear risk of bias that use of dilute formula in preterm or low 
(Continued)

Hakimi M. Dilute versus full strength formula in exclusively formula-fed preterm or low birth weight infants. Cochrane Database of Systematic Reviews 2013, Issue 11.
1. Neurodevelopment:

a. Death or severe neurodevelopmental disability defined as any 1 or a combination of the following: non-ambulant cerebral palsy; developmental delay (DQ < 70); auditory and visual impairment (each component will be analysed individually as well as part of the composite outcome)

b. Neurodevelopmental scores in survivors aged $\geq 12$ months of age measured using validated assessment tools

c. Cognitive and educational outcomes in survivors aged $>5$ years old birth weight formula-fed infants leads to an important reduction in the time taken for these infants to attain an adequate energy intake. There was no evidence of important differences in feeding intolerance. The impact on serious gastrointestinal problems, including necrotising enterocolitis, was not reported. Further randomised trials are needed to confirm these results"
Beveridge CJE, Wilkinson AR. Sodium bicarbonate infusion during resuscitation of infants at birth. Cochrane Database of Systematic Reviews 2006, Issue 1.
Secondary outcomes pre-specified include:

1. Long-term severe neurodevelopmental disability reported at any time during follow-up. Defined as any of cerebral palsy, cognitive delay (score $>2$ SD below mean for a recognised psychometric test e.g. BSID), blindness, and deafness

Bhola K, Foster JP, Osborn DA. Chest shielding for prevention of a haemodynamically significant patent ductus arteriosus in preterm infants receiving phototherapy. Cochrane Database of Systematic Reviews 2015, Issue 11.

Booth D, Evans DJ. Anticonvulsants for neonates with seizures. Cochrane Database of Systematic Reviews 2004, Issue 3.

\section{Secondary outcomes pre-specified include:}

1. Neurodevelopmental disability (after at least 18 months' postnatal age) defined as neurological abnormality including cerebral palsy on clinical examination, developmental delay $>2$ SD below population mean on a standardised test of development, blindness $(V A<6 / 60)$, or deafness (any hearing impairment requiring amplification at any time after term corrected age)
"There is insufficient evidence from randomised controlled trials to determine whether the infusion of sodium bicarbonate reduces mortality and morbidity in infants receiving resuscitation in the delivery room at birth"
"The available evidence is very low quality and insufficient to assess the safety or efficacy of chest shield during phototherapy for prevention of PDA in preterm infants. Further trials of chest shielding are warranted, particularly in settings where infants are not receiving prophylactic or early echocardiographic targeted cyclo-oxygenase inhibitors for PDA"
Primary outcomes pre-specified include:

1. Significant neurodevelopmental impairment (any 1 or combination of: cerebral palsy, developmental delay $\mathrm{DQ}>2 \mathrm{SD}$, blindness) assessed at 1 to 2 years of age

2. Death or significant neurodevelopmental impairment (any 1 or combination of: cerebral palsy, developmental delay $D Q$ $>2$ SD, blindness) assessed at 1 to 2 years of age
"At present there is little evidence from randomised controlled trials to support the use of any of the anticonvulsants currently used in the neonatal period. In the literature, there remains a body of opinion that seizures should be treated because of the concern that seizures in themselves may be harmful, although this is only supported by relatively low grade evidence (Levene 2002; Massingale 1993). Development of safe and effective treatment strategies relies on future studies of high quality (randomised controlled trials with methodology that assures validity) and of sufficient size to have the power to detect clinically important reductions in mortality and severe neurodevelopmental disability in addition to any short term reduction in seizure burden"

\footnotetext{
Bottino M, Cowett RM, Sinclair JC. Interventions for treatment of neonatal hyperglycemia in very low birth weight infants. Cochrane Database of
}

\section{Primary outcomes pre-specified include:}

1. Neurodevelopmental impairment, defined as presence of 1 or more of the following: cerebral palsy, MDI or PDI < 70, blindness or deafness assessed between 18 and 24 months' postmenstrual age or
"Evidence from randomized trials in hyperglycemic VLBW neonates is insufficient to determine the effects of treatment on death or major morbidities. It remains uncertain whether the hyperglycemia per se is a cause of adverse clinical outcomes or how the hyperglycemia should be treated. Much larger randomized trials in hyperglycemic VLBW neonates that are powered on clinical outcomes are 
(Continued)

Systematic Reviews

2011, Issue 10. with latest assessment up to 24 months' postmenstrual age
Brion LP, Bell EF, Raghuveer TS. Vitamin E supplementation for prevention of morbidity and mortality in preterm infants. Cochrane Database of Systematic Reviews 2003, Issue 4.
Primary outcomes pre-specified include:

1. Mortality, combined outcome at 18 months including mortality (mortality, bronchopulmonary dysplasia, blindness, mental retardation, or cerebral palsy), and combined outcome at 18 months excluding mortality (bronchopulmonary dysplasia, blindness, mental retardation, or cerebral palsy)
Brown JVE, Embleton ND, Harding JE, McGuire W. Multi-nutrient fortification of human milk for preterm infants. Cochrane Database of Systematic Reviews 2016, Issue 5 .

\section{Primary outcomes pre-specified include:}

1. Neurodevelopmental outcomes assessed after 12 months post term: neurological evaluations, developmental scores, and classifications of disability, including auditory and visual disability. We defined neurodevelopmental impairment as the presence of 1 or more of the following: non-ambulantcerebral palsy, DQ $>2$ SD below the population mean, and blindness $(V A<6 / 60)$ or deafness (any hearing impairment requiring or unimproved by amplification) needed in order to determine whether, and how, the hyperglycemia should be treated"
"Vitamin E supplementation in preterm infants reduced the risk of intracranial hemorrhage but increased the risk of sepsis. In very low birth weight infants, vitamin $\mathrm{E}$ increased the risk of sepsis, and reduced the risk of severe retinopathy and blindness among those examined. Evidence does not support the routine use of vitamin E supplementation by intravenous route at high doses or aiming at serum tocopherol levels greater than $3.5 \mathrm{mg} / \mathrm{dl}$ "

"Limited available data do not provide strong evidence that feeding preterm infants with multi-nutrient fortified breast milk compared with unfortified breast milk affects important outcomes, except that it leads to slightly increased in-hospital growth rates"
Brown JVE, Moe-Byrne T, McGuire W. Glutamine supplementation for young infants with severe gastrointestinal disease. Cochrane Database of Systematic Reviews 2014, Issue 12.
Primary outcomes pre-specified include:

1. Neurodevelopmental outcomes assessed beyond infancy (neurological evaluations, developmental scores, and classifications of disability including auditory and visual disability, non-ambulant cerebral palsy, and developmental delay) and cognitive and educational outcomes (IQ and/or indices of educational achievement measured using a validated tool, including school examination results)
Bruschettini M, Romantsik O, Zappettini S, Banzi R, Ramenghi LA, Calevo MG. Antithrombin for the prevention of intraventricular hemorrhage in very preterm infants. Cochrane Database of Systematic Reviews 2016, Issue 3.
Secondary outcomes pre-specified include:

1. Major neurodevelopmental disability assessed at age of 12 months or more (defined as cerebral palsy, developmental delay (BSID or GMDS assessment > 2 SD below the mean), intellectual impairment (IQ > 2 SD below mean), blindness (vision < $6 / 60$ in both eyes), or sensorineural deafness requiring amplification)
"The available data from randomised controlled trials do not suggest that glutamine supplementation has any important benefits for young infants with severe gastrointestinal disease"
Bruschettini M, Zappettini S, Moja L, Calevo MG. Frequency of endotracheal suctioning for the prevention of respiratory morbidity in ventilated newborns. Cochrane Data-
Secondary outcomes pre-specified include:

1. Major neurodevelopmental disability (cerebral palsy, developmental delay (BSID or GMDS assessment $>2$ SD below the mean) or intellectual impairment ( $\mathrm{IQ}>2 \mathrm{SD}$ below mean), blindness (vision less than $6 / 60$ in both eyes), sensorineur-
"The administration of antithrombin seems not to reduce the incidence and severity of intraventricular hemorrhage in very preterm infants. Limited evidence is available on other clinically relevant outcomes. Given the imprecision of the estimate, the results of this systematic review are consistent with either a benefit or a detrimental effect of antithrombin and do not provide a definitive answer to the review question"
"There was insufficient evidence to identify the ideal frequency of ETT suctioning in ventilated neonates. Future research should focus on the effects in the very preterm newborns, that is, the most vulnerable population as concerns the risk of both lung and brain damage. Assessment should include the cases of prolonged ventilation, when more abundant, dense secretions are common. Clinical trials might include comparisons between 'as-scheduled' 
(Continued)

base of Systematic Reviews 2016, Issue 3. al deafness requiring amplification). We evaluated each component of major neurodevelopmental disability:

a. Cerebral palsy on physician assessment (yes/no)

b. Developmental delay or intellectual impairment: BSID or GMDS assessment $>2$ SD below the mean or intellectual impairment (IQ > 2 SD below mean); neuromotor development (BSID PDI) assessed in survivors; mental development (BSID MDI) assessed in survivors

c. Blindness vision (less than $6 / 60$ in both eyes)

d. Sensorineural deafness requiring amplification
Bruschettini M, Romantsik O, Zappettini $\mathrm{S}$, Banzi R, Ramenghi LA, Calevo MG. Heparin for the prevention of intraventricular haemorrhage in preterm infants. Cochrane Database of Systematic Reviews 2016, Issue 5.
Secondary outcomes pre-specified include:

1. Long-term neurodevelopmental outcome (yes/no): cerebral palsy on physician assessment, developmental delay, i.e. IQ 2 SD below the mean on validated assessment tools, e.g. BSID MDI (Bayley 1993; Bayley 2006)

2. Major neurodevelopmental disability: cerebral palsy, developmental delay (BSID MDI (Bayley 1993; Bayley 2006) or GMDS assessment (Griffiths 1954) > 2 SD below the mean), intellectual impairment (IQ $>2$ SD below mean), blindness (vision $<6 / 60$ in both eyes), or sensorineural deafness requiring amplification ( $\mathrm{Ja}$ cobs 2013). We planned to evaluate each of these components as a separate outcome and to extract data on this longterm outcome from studies that evaluated children after 18 months of chronological age. Data on children aged 18 to 24 months and those aged 3 to 5 years were to be assessed separately
Bruschettini M, Romantsik O, Zappettini S, Ramenghi LA, Calevo MG. Transcutaneous carbon dioxide monitoring for the prevention of neonatal morbidity and mortality. Cochrane Database of Systematic Reviews 2016, Issue 2.

\section{Primary outcomes pre-specified include:}

1. Major neurodevelopmental disability (cerebral palsy, developmental delay (BSID or GMDS > 2 SD below the mean) or intellectual impairment (IQ $>2$ SD below mean), blindness (vision $<6 / 60$ in both eyes), sensorineural deafness requiring amplification) (Jacobs 2013)

Secondary outcomes pre-specified include:

1. Each component of major neurodevelopmental disability: (a)cerebral palsy on physician assessment (yes/no); (b) developmental delay or intellectual impairment: BSID or GMDS assessment > 2 SD below the mean or intellectual impairment (IQ > 2 SD below mean); neuromo- versus 'as-needed' endotracheal suctioning, that is, based on specific indications, as well frequent versus less frequent suctioning schedules"
"There is very limited data on the effect of prophylactic administration of heparin on the incidence and severity of IVH in very preterm neonates. Both the identified trials used heparin in the context of maintaining umbilical line patency and not specifically as an agent to prevent germinal matrix-intraventricular haemorrhage. Given the imprecision of our estimates, the results of this systematic review are consistent with either a benefit or a detrimental effect of heparin and do not provide a definitive answer to the review question. Limited evidence is available on other clinically relevant outcomes"

\section{No included trials}

"There was no evidence to recommend or refute the use of transcutaneous $\mathrm{CO} 2$ monitoring in neonates. Well-designed, adequately powered randomized controlled studies are necessary to address efficacy and safety of transcutaneous $\mathrm{CO} 2$ monitoring in neonates" 
tor development (BSID PDI) assessed in survivors; mental development (BSID MDI) assessed in survivors; (c) blindness vision (<6/60 in both eyes); (d) sensorineural deafness requiring amplification. We will report these components of this longterm outcome for all trials that have evaluated children after 18 months' chronological age. We will perform separate analyses for children aged 18 months to 24 months and those aged 3 years to 5 years

Cleminson J, McGuire W. Topical emollient for preventing infection in preterm infants. Cochrane Database of Systematic Reviews 2016, Issue 1.
Secondary outcomes pre-specified include:

1. Neurodevelopmental outcomes assessed at $>12$ months post term (measured using validated assessment tools) and classifications of disability, including auditory and visual disability. A composite outcome "severe neurodevelopmental disability" was defined as any 1 or combination of the following: non-ambulant cerebral palsy, severe developmental delay, auditory impairment, and visual impairment
"The available data do not provide evidence that the use of emollient therapy prevents invasive infection or death in preterm infants in high-, middle- or low-income settings. Some evidence of an effect of topical vegetable oils on neonatal growth exists but this should be interpreted with caution because lack of blinding may have introduced caregiver or assessment biases. Since these interventions are low cost, readily accessible, and generally acceptable, further randomised controlled trials, particularly in both community- and health care facility-based settings in low-income countries, may be justified"
Clerihew L, McGuire W. Antifungal therapy for newborn infants with invasive fungal infection. Cochrane Database of Systematic Reviews 2012, Issue 6.
Primary outcomes pre-specified include:

1. Neurodevelopmental outcomes assessed beyond infancy (neurological evaluations, developmental scores, and classifications of disability, including auditory and visual disability, non-ambulant cerebral palsy, developmental delay) and cognitive and educational outcomes (IQ and/or indices of educational achievement measured using a validated tool including school examination results)
Cooke L, Steer PA, Woodgate PG. Indomethacin for asymptomatic patent ductus arteriosus in preterm infants. Cochrane Database of Systematic Reviews 2003, Issue 1.
Outcomes pre-specified include:

1. Neurodevelopmental outcome (cerebral palsy, sensorineural hearing loss, visual impairment, developmental delay)
"There are insufficient data to inform practice. Large randomised controlled trials are required to compare antifungal drugs, drug preparations or drug combinations for treating newborn infants with invasive fungal infection"
Davies MW, Kimble RM, Woodgate PG. Ward reduction without general anaesthesia versus reduction and repair under general anaesthesia for gastroschisis in newborn infants. Cochrane Database of Systematic Reviews 2002, Issue 3.

\section{Outcomes pre-specified include:}

1. Neurodevelopmental outcome (cerebral palsy, sensorineural hearing loss, visual impairment, and/or developmental delay)
"This review demonstrates a significant decrease in the incidence of symptomatic PDA following treatment of an asymptomatic PDA with indomethacin. There is also a small but statistically significant decrease in the duration of requirement for supplemental oxygen. There are no reported long term outcomes in the included trials, and so it is not possible to comment on possible long term effects. Further studies are required to determine the long term benefits or harms of closing a PDA prior to the onset of symptoms"

\section{No included trials}

"There is no evidence from RCTs to support or refute the practice of ward reduction for the immediate management of gastroschisis. There is an urgent need for RCTs to compare ward reduction versus reduction under general anaesthesia in infants with gastroschisis. Initial trials would best be limited to those infants with uncomplicated gastroschisis (using pre-defined selection criteria excluding infants that are unstable, have gut perforation, necrosis or atresia, have other organs requiring reduction 
besides bowel, or are considered to need a silo prior to any reduction). Trials should use adequate pain relief and specify a pre-defined time period after which manual reduction is abandoned"

Davies MW, Woodgate PG. Tracheal gas insufflation for the prevention of morbidity and mortality in mechanically ventilated newborn infants. Cochrane Database of Systematic Reviews 2002, Issue 2.

\section{Outcomes pre-specified include:}

1. Neurodevelopmental outcome (cerebral palsy, sensorineural hearing loss, visual impairment, and/or developmental delay) at 1, 2, 3, 5, or 7 years
De Paoli AG, Davis PG, Faber B, Morley CJ. Devices and pressure sources for administration of nasal continuous positive airway pressure (NCPAP) in preterm neonates. Cochrane Database of Systematic Reviews 2008, Issue 1.
Secondary outcomes pre-specified include:

1. Long-term neurosensory outcomes at 2 years' corrected age or older as defined by the incidence of: lay
c. Blindness
d. Deafness

a. Cerebral palsy

b. Moderate to severe developmental de-
"There is evidence from a single RCT that TGI may reduce the duration of mechanical ventilation in preterm infants - although the data from this small study do not give sufficient evidence to support the introduction of TGI into clinical practice. The technical requirements for performing TGI (as performed in the single included study) are great. There is no statistically significant reduction in the total duration of respiratory support or hospital stay. TGI cannot be recommended for general use at this time"
Dimmick SJ, Badawi N, Randell T. Thyroid hormone supplementation for the prevention of morbidity and mortality in infants undergoing cardiac surgery. Cochrane Database of Systematic Reviews 2004, Issue 3.

\section{Outcomes pre-specified include:}

1. Development: neurological abnormality (cerebral palsy) or developmental delay on standardised tests in the first year 5
"Short binasal prong devices are more effective than single prongs in reducing the rate of re-intubation. Although the Infant Flow Driver appears more effective than Medicorp prongs the most effective short binasal prong device remains to be determined. The improvement in respiratory parameters with short binasal prongs suggests they are more effective than nasopharyngeal CPAP in the treatment of early RDS. Further studies incorporating longer-term outcomes are required. Studies are also needed to determine the optimal pressure source for the delivery of NCPAP"
"At present, there is a lack of evidence concerning the effects of triiodothyronine supplementation in infants undergoing cardiac surgery. Further randomised controlled trials which include sufficiently large subject numbers in a variety of different age strata (neonates, infants and older children) need to be undertaken"
Foster JP, Psaila K, Patterson T. Non-nutritive sucking for increasing physiologic stability and nutrition in preterm infants. Cochrane Database of Systematic Reviews 2016, Issue 10.
Secondary outcomes pre-specified include:

1. Neurodevelopmental outcomes at 12 months or more of age (corrected for preterm birth) measured using validated assessment tools such as BSID and classifications of disability, including auditory and visual disability. Severe neurodevelopmental disability will be defined as any one or combination of the following: nonambulant cerebral palsy, developmental delay (developmental quotient $<70$ ), auditory and visual impairment
Görk AS, Ehrenkranz RA, Bracken MB. Continuous infusion versus intermittent bolus doses of indomethacin for patent ductus arteriosus closure in symptomatic preterm infants.

\section{Secondary outcomes pre-specified include:}

1. Neurodevelopmental outcome (sensorineural hearing loss, visual impairment, cerebral palsy, developmental delay at 24 months' corrected age assessed by a standardised and validated assess-
"Meta-analysis demonstrated a significant effect of NNS on the transition from gavage to full oral feeding, transition from start of oral feeding to full oral feeding, and length of hospital stay. None of the trials reported any adverse effects. Well-designed, adequately powered studies using reliable methods of randomisation, concealment of treatment allocation and blinding of the intervention and outcome assessors are needed. In order to facilitate metaanalysis of these data, future research should involve outcome measures consistent with those used in previous studies"

"The available data is insufficient to draw conclusions regarding the efficacy of continuous indomethacin infusion vs. bolus injections for the treatment of PDA. Although continuous indomethacin seems to cause less alterations in cerebral, renal and mesenteric circulations, the clinical meaning of this effect is unclear. Definitive recommendations about the preferred method of indomethacin admin- 
(Continued)

Cochrane Database of Systematic Reviews 2008, Issue 1. ment tool and/or a child developmental specialist) istration in premature infants cannot be made based on the current findings of this review"
Henderson G, Anthony MY, McGuire W. Formula milk versus maternal breast milk for feeding preterm or low birth weight infants. Cochrane Database of Systematic Reviews 2007, Issue 4.
Primary outcomes pre-specified include:

1. Development:

a. Neurodevelopmental outcomes at $\geq 12$ months of age (corrected for preterm birth) measured using validated assessment tools

b. Severe neurodevelopmental disability defined as any 1 or combination of the following: non-ambulant cerebral palsy, developmental delay ( $D Q<70$ or $>2$ SD below the mean), severe auditory impairment (sensorineural deafness requiring (or too severe to (benefit from) hearing aids), or visual impairment (legal blindness). We plan to analyse each component individually as well as part of the composite outcome

c. Cognitive and educational outcomes at age > 5 years: IQ and/or indices of educational achievement measured using a validated assessment tool (including school examination results)
No included trials

"There are no data from randomised trials of formula milk versus maternal breast milk for feeding preterm or low birth weight infants. This may relate to a perceived difficulty of allocating an alternative feed to an infant whose mother wishes to feed with her own breast milk. Maternal breast milk remains the default choice of enteral nutrition because observational studies, and meta-analyses of trials comparing feeding with formula milk versus donor breast milk, suggest that feeding with breast milk has major non-nutrient advantages for preterm or low birth weight infants"
Henderson G, Fahey T, McGuire W. Nutrient-enriched formula milk versus human breast milk for preterm infants following hospital discharge. Cochrane Database of Systematic Reviews 2007, Issue 4.

\section{Primary outcomes pre-specified include:}

1. Neurodevelopmental outcomes at $\geq 12$ months of age (corrected for preterm birth) measured using validated assessment tools such as BSID and classifications of disability, including auditory and visual disability. Severe neurodevelopmental disability will be defined as any 1 or combination of the following: nonambulant cerebral palsy, developmental delay ( $\mathrm{DQ}<70)$, auditory and visual impairment

\section{No included trials}

"There are no data from randomised controlled trials to determine whether feeding preterm infants following hospital discharge with nutrient-enriched formula milk versus human breast milk affects growth and development. Mothers who wish to breast feed, and their health care advisors, would require very clear evidence that feeding with a nutrient-enriched formula milk had major advantages for their infants before electing not to feed (or to reduce feeding) with maternal breast milk. If evidence from trials that compared feeding preterm infants following hospital discharge with nutrient-enriched versus standard formula milk demonstrated an effect on growth or development, then this might strengthen the case for undertaking trials of nutrient-enriched formula milk versus human breast milk"

"When MV was introduced in the 1960 s to treat infants with severe respiratory failure due to pulmonary disease, trials showed an overall reduction in mortality which was most marked in infants born with a birthweight of more than $2 \mathrm{~kg}$. This review does not provide information to evaluate the relative benefits or harms of MV in the setting of modern perinatal care"
Henderson-Smart DJ, Wilkinson AR, RaynesGreenow CH. Mechanical ventilation for newborn infants with respiratory failure due to pulmonary disease. Cochrane Database of Systematic Reviews 2002, Issue 4.
Secondary outcomes pre-specified include:

1. Neurodevelopmental abnormalities in childhood (developmental delay, cerebral palsy)
Ho JJ, Henderson-Smart DJ, Davis PG.
Secondary outcomes pre-specified include:

"Early application of CDP has a clinical benefit in the treatment of RDS in that it reduces subsequent use of IP- 
(Continued)

Early versus delayed initiation of continuous distending pressure for respiratory distress syndrome in preterm infants. Cochrane Database of Systematic Reviews 2002, Issue 2.
1. Long-term growth and neurodevelopmental outcome (cerebral palsy and abnormal mental development $<2$ SD below the mean on a standardised score)
PV and thus may be useful in preventing the adverse effects of this treatment. However, many of the trials were done in the 1970s and 1980s and re-evaluation of the strategy of early CDP in the era of antenatal steroid use and early surfactant administration is indicated focusing on administration methods"
Ho JJ, Rasa G. Magnesium sulfate for persistent pulmonary hypertension of the newborn. Cochrane Database of Systematic Reviews 2007, Issue 3.
Secondary outcomes pre-specified include:

1. Cerebral palsy on physician assessment

\section{No included trials}

"On the basis of the current lack of evidence, the use of magnesium sulphate cannot be recommended in the treatment of PPHN. Randomised controlled trials are recommended"

\section{Hunt R, Osborn DA.} Dopamine for prevention of morbidity and mortality in term newborn infants with suspected perinatal asphyxia. Cochrane Database of Systematic Reviews 2002, Issue 3 .
Primary outcomes pre-specified include:

1. Neurodevelopmental disability (neurological abnormality including cerebral palsy, developmental delay $>2$ SD below population mean, or sensory impairment)

(Review reports on 'neurodevelopmental disability' for 1 RCT (14 infants), which did not include cerebral palsy)
"There is currently insufficient evidence from randomised controlled trials that the use of dopamine in term infants with suspected perinatal asphyxia improves mortality or long-term neurodevelopmental outcome. The question of whether dopamine improves outcome for term infants with suspected perinatal asphyxia has not been answered. Further research is required to determine whether or not the use of dopamine improves mortality and long-term morbidity for these infants and if so, issues such as which infants, at what dose and with what co-interventions should be addressed"
Hunt R, Davis PG, Inder TE. Replacement of estrogens and progestins to prevent morbidity and mortality in preterm infants. Cochrane Database of Systematic Reviews 2004, Issue 4.
Primary outcomes pre-specified include:

1. Neurodevelopmental disability defined as neurological abnormality includingcerebral palsy on clinical examination $>12$ months' postnatal age, developmental delay $>2$ SD below population mean on any standard test of development, blindness (VA $<6 / 60)$, or deafness (any hearing impairment requiring amplification) at any time after term corrected
"The one small randomised controlled trial demonstrated neither evidence of benefit or harm related to the replacement of estradiol and progesterone in preterm infants less than 30 weeks' gestation. A properly powered randomised controlled trial is required to determine whether or not administration of estradiol or progesterone, either alone or in combination, and at varying doses, confers any clinically significant benefits, or poses any risk, to the preterm infant"
Ibrahim H, Sinha IP, Subhedar NV. Corticosteroids for treating hypotension in preterm infants. Cochrane Database of Systematic Reviews 2011, Issue 12.
Primary outcomes pre-specified include:

1. Long-term neurodevelopmental outcome (cerebral palsy, developmental delay, sensorineural impairment, abnormal neurological examination)

\begin{abstract}
"Hydrocortisone may be as effective as dopamine when used as a primary treatment for hypotension. But the long term safety data on the use of hydrocortisone in this manner is unknown. Steroids are effective in treatment of refractory hypotension in preterm infants without an increase in short term adverse consequences. However, long term safety or benefit data is lacking. With long term benefit or safety data lacking steroids cannot be recommended routinely for the treatment of hypotension in preterm infants"
\end{abstract}

Ibrahim MDH, Sinn JKH, McGuire W. lodine supplementation for the prevention of mortality and adverse neurodevelopmental outcomes in preterm infants. Cochrane Data-

\section{Primary outcomes pre-specified include:}

1. Neurodevelopmental outcomes at $\geq 12$ months of age (corrected for preterm birth) measured using validated assessment tools such as BSID

2. Severe neurodevelopmental disability defined as any 1 or combination of the fol-
"There are insufficient data at present to determine whether providing preterm infants with supplemental iodine (to match fetal accretion rates) prevents morbidity and mortality in preterm infants. Future randomised controlled trials of iodine supplementation should focus on extremely preterm and extremely low birth weight infants, the group at greatest risk of transient hypothyroxinaemia. These trials should aim to assess the effect of iodine sup- 
(Continued)

base of Systematic Reviews 2006, Issue 2. lowing: non-ambulant cerebral palsy, developmental delay ( $\mathrm{DQ}<70)$, auditory and visual impairment. We planned to analyse each component individually as well as part of the composite outcome
Inglis GDT, Davies MW. Prophylactic antibiotics to reduce morbidity and mortality in neonates with umbilical venous catheters. Cochrane Database of Systematic Reviews 2005, Issue 4.
Secondary outcomes pre-specified include:

1. Neurodevelopmental outcome (cerebral palsy, sensorineural hearing loss, visual impairment and/or developmental delay will be considered as separate components - at 1 year, 18 months, 2 years, or 5 years) plementation on clinically important outcomes including respiratory morbidity and longer term neurodevelopment"
"There is insufficient evidence from randomised trials to support or refute the use of prophylactic antibiotics when UVCs are inserted in newborn infants. There is no evidence to support or refute continuing antibiotics once initial cultures rule out infection in newborn infants with UVCs"
Inglis GDT, Jardine LA, Davies MW. Prophylactic antibiotics to reduce morbidity and mortality in ventilated newborn infants. Cochrane Database of Systematic Reviews 2007, Issue 3.
Secondary outcomes pre-specified include:

1. Neurodevelopmental outcome (cerebral palsy, sensorineural hearing loss, visual impairment and/or developmental delay at 1 year, 18 months, 2 years, or 5 years)
"There is insufficient evidence from randomised trials to support or refute the use of prophylactic antibiotics when starting mechanical ventilation in newborn infants, or to support or refute continuing antibiotics once initial cultures have ruled out infection in mechanically ventilated newborn infants"
Inglis GDT, Jardine LA, Davies MW. Prophylactic antibiotics to reduce morbidity and mortality in neonates with umbilical artery catheters. Cochrane Database of Systematic Reviews 2007, Issue 4.
Secondary outcomes pre-specified include:

1. Neurodevelopmental outcome (cerebral palsy, sensorineural hearing loss, visual impairment and/or developmental delay at 1 year, 18 months, 2 years, or 5 years)
"There is insufficient evidence from randomised trials to support or refute the use of prophylactic antibiotics when umbilical artery catheters are inserted in newborn infants, and no evidence to support or refute continuing antibiotics once initial cultures rule out infection in newborn infants with umbilical artery catheters"
Jardine LA, Inglis GDT, Davies MW. Prophylactic systemic antibiotics to reduce morbidity and mortality in neonates with central venous catheters. Cochrane Database of Systematic Reviews 2008, Issue 1.
Secondary outcomes pre-specified include:

1. Neurodevelopmental outcome (cerebral palsy, sensorineural hearing loss, visual impairment, and/or developmental delay - at 1 year, 18 months, 2 years, or 5 years)
"Prophylactic systemic antibiotics in neonates with a central venous catheter reduces the rate of proven or suspected septicaemia. However, this may not be clinically important in the face of no significant difference in overall mortality and the lack of data on long-term neurodevelopmental outcome. Furthermore, there is a lack of data pertaining to the potentially significant disadvantages of this approach such as the selection of resistant organisms. The routine use of prophylactic antibiotics in infants with central venous catheters in neonatal units cannot currently be recommended"

"Infants who have their NCPAP pressure weaned to a predefined level and then stop NCPAP completely have less total time on NCPAP and shorter durations of oxygen therapy and hospital stay compared with those that have NCPAP removed for a predetermined number of hours each day. Future trials of withdrawing NCPAP should compare proposed strategies with weaning NCPAP pressure to a predefined level and then stopping NCPAP completely. Clear criteria need to be established for the definition of stability prior to attempting to withdraw NCPAP" , Issue 2. Art. No.: CD006979. DOI: 10.1002/14651858.CD006979.pub2.

Secondary outcomes pre-specified include:

1. Neurodevelopmental outcome (cerebral palsy, sensorineural hearing loss, visual impairment, and/or developmental delay - at 1 year, 18 months, 2 years, or 5 years) 
(Continued)

Kaushal A, McDonnell CG, Davies MW. Partial liquid ventilation for the prevention of mortality and morbidity in paediatric acute lung injury and acute respiratory distress syndrome. Cochrane Database of Systematic Reviews 2013, Issue 2.
Secondary outcomes pre-specified include:

1. Long-term neurodevelopment (cerebral palsy, sensorineural hearing loss, visual impairment, developmental delay)

2. Long-term disability
"There is no evidence from RCTs to support or refute the use of partial liquid ventilation in children with acute lung injury or acute respiratory distress syndrome. Adequately powered, high quality RCTs are still needed to assess its efficacy. Clinically relevant outcome measures should be assessed (mortality at discharge and later, duration of both respiratory support and hospital stay, and long-term neurodevelopmental outcomes). The studies should be published in full"
Kecskes Z, Healy G, Jensen A. Fluid restriction for term infants with hypoxic-ischaemic encephalopathy following perinatal asphyxia. Cochrane Database of Systematic Reviews 2005, Issue 3.
Primary outcomes pre-specified include:

1. Severe neurodevelopmental disability at or equal to 12 months of age or more. Severe neurodevelopmental disability was defined as cerebral palsy, developmental delay $(\mathrm{DQ}<70$ ) or blindness (VA $<6 / 60$ in both eyes), or any combination of these disabilities

\section{No included trials}

"Given that fluid restriction for the treatment of hypoxic ischaemic encephalopathy following perinatal asphyxia is recommended in standard textbooks, there is a need for randomised, controlled trials to establish if this practice affects mortality and morbidity. As it may not be ethical to include neonates with acute renal failure in a randomised trial, these babies will have to be excluded from the trial. These studies should investigate the effects of fluid management on outcomes such as mortality, seizure activity, evidence of cerebral damage on histology, and effects on renal function and electrolytes"

"We identified a single small study. The results from this study show a high level of uncertainty, as the confidence intervals are consistent with both a large improvement or a serious harm caused by the intervention. Consequently, there is insufficient evidence to support or refute the use of washed RBCs to prevent the development of significant neonatal morbidities or mortality. Further clinical trials are required to assess the potential effects of pre-transfusion washing of RBCs for preterm or very low birth weight infants, or both, on short- and long-term outcomes"
Cochrane Database of Systematic Reviews 2016, Issue 1.
1. Composite outcome of mortality or severe adverse neurosensory outcome (or its complement, survival without serious adverse neurosensory outcome) at a defined period of follow-up at age 18 to 24 months' adjusted gestational age or older, where adverse neurosensory outcome is defined as:

a. Cerebral palsy by physician assessment

b. DQ ( $>2$ SD below the mean on validated assessment tool of cognitive function (e.g. BSID))

c. Blindness (VA $<20 / 200$ in best eye)

d. Deafness (hearing loss requiring amplification or cochlear implantation)
Kylat RI, Ohlsson A. Recombinant human activated protein $\mathrm{C}$ for severe sepsis in neonates. Cochrane Database of Systematic Reviews 2012, Issue 4.
Secondary outcomes pre-specified include:

1. Severe disability, defined as any of blindness, deafness, cerebral palsy or cognitive delay (score $>2$ SD below the mean for a recognised psychometric test for neurodevelopmental outcome assessed by a validated test, e.g. BSID), or adverse neurological outcome, at 18 months of age or later. These outcomes will be reported
"Despite the scientific rationale for its use, there is insufficient data to use rhAPC for the management of severe sepsis in newborn infants. Due to the results among adults with lack of efficacy, an increase in bleeding and resulting withdrawal of rhAPC from the market, neonates should not be treated with rhAPC and further trials should not be conducted" 
both as a composite outcome and individ-

ually

\section{Cerebral palsy}

Lai NM, Foong SC, Foong WC, Tan K. Cobedding in neonatal nursery for promoting growth and neurodevelopment in stable preterm twins. Cochrane Database of Systematic Reviews 2016, Issue 4.

\section{Secondary outcomes pre-specified include:}

1. Long-term neurodevelopment, measured by validated scales such as BSID (Washington 1998), whereby average scores between twin pairs would be taken if data were available. Clinically diagnosed nonambulatory cerebral palsy or significant auditory and visual impairment would be accepted if data were available
"Evidence on the benefits and harms of co-bedding for stable preterm twins was insufficient to permit recommendations for practice. Future studies must be adequately powered to detect clinically important differences in growth and neurodevelopment. Researchers should assess harms such as infection, along with medication errors and caregiver satisfaction"
Lai NM, Rajadurai SV, Tan K. Increased energy intake for preterm infants with (or developing) bronchopulmonary dysplasia/chronic lung disease. Cochrane Database of Systematic Reviews 2006, Issue 3.

\section{Secondary outcomes pre-specified include:}

1. Neurodevelopmental disabilities at or after 12 months' corrected age, assessed using validated tools like BSID, including diagnosed cerebral palsy, blindness, or deafness

2. Mortality or neurodevelopmental disabilities

\section{No included trials}

"To date, no randomised controlled trials are available that examine the effects of increased versus standard energy intake for preterm infants with (or developing) CLD/ BPD. Research should be directed at evaluating the effects of various levels of energy intake on this group of infants on clinically important outcomes like mortality, respiratory status, growth and neurodevelopment. The benefits and harms of various ways of increasing energy intake, including higher energy density of milk feed and/or fluid volume (clinically realistic target volume should be set), parenteral nutrition, and the use of various constituents of energy like carbohydrate, protein and fat for this purpose also need to be assessed"

"Based on moderate-quality evidence, chlorhexidine dressing/alcohol skin cleansing reduced catheter colonisation, but made no significant difference in major outcomes like sepsis and CRBSI compared to polyurethane dressing/povidone-iodine cleansing. Chlorhexidine dressing/alcohol cleansing posed a substantial risk of contact dermatitis in preterm infants, although it was unclear whether this was contributed mainly by the dressing material or the cleansing agent. While silver-alginate patch appeared safe, evidence is still insufficient for a recommendation in practice. Future research that evaluates antimicrobial dressing should ensure blinding of caregivers and outcome assessors and ensure that all participants receive the same co-interventions, such as the skin cleansing agent. Major outcomes like sepsis, CRBSI and mortality should be assessed in infants of different gestation and birth weight"

"This review highlighted the need for further well designed and completed studies to be conducted for this common neonatal procedure. Evidence is lacking to determine the most effective and safe method to stabilise the endotracheal tube in the ventilated neonate"

\footnotetext{
Lai M, Inglis GDT, Hose $\mathrm{K}$, Jardine LA, Davies MW. Methods for securing endotracheal tubes in newborn infants. Cochrane Database of Systematic Reviews 2014, Issue 7.
}

\section{Secondary outcomes pre-specified include:}

1. Incidence of an adverse neurodevelopmental outcome (e.g. cerebral palsy, sensorineural hearing loss, visual impairment, developmental delay) whenever measured in the primary studies
Lawn CJ, Weir FJ,
McGuire W. Base ad-
Secondary outcomes pre-specified include:
"There is insufficient evidence from randomised controlled trials to determine whether infusion of base or flu- 
(Continued) ministration or fluid bolus for preventing morbidity and mortality in preterm infants with metabolic acidosis. Cochrane Database of Systematic Reviews 2005, Issue 2.
1. Neurodevelopmental outcomes at $\geq 12$ months of age (corrected for preterm birth) measured using validated assessment tools such as BSID and classifications of disability, including (a) auditory and (b) visual disability. The composite outcome of "severe neurodevelopmental disability" is defined as any 1 or combination of the following: non-ambulant cerebral palsy, developmental delay (DQ < 70), auditory and visual impairment id bolus reduces morbidity and mortality in preterm infants with metabolic acidosis. Further large randomised trials are needed"

\begin{abstract}
Malwade US, Jardine LA. Home- versus hospital-based phototherapy for the treatment of non-haemolytic jaundice in infants at more than 37 weeks' gestation. Cochrane Database of Systematic Reviews 2014, Issue 6.
\end{abstract}

\section{Primary outcomes pre-specified include:}

1. Incidence (percentage) of chronic bilirubin encephalopathy or kernicterus, defined by a tetrad of choreoathetoid cerebral palsy, high-frequency sensorineural hearing loss, palsy of vertical gaze, and dental enamel hypoplasia

\section{No included trials}

"No high-quality evidence is currently available to support or refute the practice of home-based phototherapy for non-haemolytic jaundice in infants at more than 37 weeks' gestation"
McGuire W, Fowlie PW, Evans DJ. Naloxone for preventing morbidity and mortality in newborn infants of greater than 34 weeks' gestation with suspected perinatal asphyxia. Cochrane Database of Systematic Reviews 2004, Issue 1.
Primary outcomes pre-specified include:

1. Severe neurodevelopmental disability assessed at $\geq 12$ months of age. Severe neurodevelopmental disability will be defined as any 1 or combination of the following: non-ambulant cerebral palsy, developmental delay ( $\mathrm{DQ}<70)$, auditory and visual impairment. Development should have been assessed by means of a previously validated tool, such as BSID PDI and MDI
"There are insufficient data available to evaluate the safety and effectiveness of the routine use of naloxone for newborn infants of greater than 34 weeks' gestation with suspected perinatal asphyxia. A further randomised controlled trial is needed to determine if naloxone benefits newborn infants with suspected perinatal asphyxia. Such a trial should assess clinically important outcomes such as mortality, and adverse short and long term neurological outcomes"
Morgan J, Bombell S, McGuire W. Early trophic feeding versus enteral fasting for very preterm or very low birth weight infants. Cochrane Database of Systematic Reviews 2013, Issue 3.
Secondary outcomes pre-specified include:

1. Neurodevelopment: death or severe neurodevelopmental disability defined as any 1 or combination of the following: nonambulant cerebral palsy, developmental delay ( $\mathrm{DQ}<70$ ), auditory and visual impairment. Each component will be analysed individually as well as part of the composite outcome Morgan J, Young L,
McGuire W. Slow advancement of enteral feed volumes to prevent necrotising enterocolitis in very low birth weight infants. Cochrane Database of Systematic Reviews 2015, Issue 10.
Secondary outcomes pre-specified include:

1. Neurodevelopment:

a. Death or severe neurodevelopmental disability defined as any 1 or a combination of the following: non-ambulatory cerebral palsy, developmental delay $(\mathrm{DQ}<70)$, auditory and visual impairment. Each component was to be analysed individually as well as part of the composite outcome

b. Neurodevelopmental scores in survivors aged 12 months or greater measured using validated assessment tools
"The available trial data do not provide evidence of important beneficial or harmful effects of early trophic feeding for very preterm or very low birth weight infants. The applicability of these findings to extremely preterm, extremely low birth weight or growth restricted infants is limited. Further randomised controlled trials would be needed to determine how trophic feeding compared with enteral fasting affects important outcomes in this population"

"The available trial data suggest that advancing enteral feed volumes at daily increments of 30 to $40 \mathrm{~mL} / \mathrm{kg}$ (compared to 15 to $24 \mathrm{~mL} / \mathrm{kg}$ ) does not increase the risk of NEC or death in VLBW infants. Advancing the volume of enteral feeds at slow rates results in several days of delay in establishing full enteral feeds and increases the risk of invasive infection. The applicability of these findings to extremely preterm, extremely low birth weight, or growthrestricted infants is limited. Further randomised controlled trials in these populations may be warranted to resolve this uncertainty" 
c. Cognitive and educational outcomes in survivors aged $>5$ years

Morgan J, Young L, McGuire W. Delayed introduction of progressive enteral feeds to prevent necrotising enterocolitis in very low birth weight infants. Cochrane Database of Systematic Reviews 2014, Issue 12.
Secondary outcomes pre-specified include:

1. Neurodevelopment:

a. Death or severe neurodevelopmental disability defined as any 1 or combination of the following: non-ambulant cerebral palsy, developmental delay (DQ < 70), auditory and visual impairment. Each component was analysed individually as well as part of the composite outcome

b. Neurodevelopmental scores in survivors aged 12 months or greater measured using validated assessment tools

c. Cognitive and educational outcomes in survivors aged $>5$ years
Mosalli R, AlFaleh K. Prophylactic surgical ligation of patent ductus arteriosus for prevention of mortality and morbidity in extremely low birth weight infants. Cochrane Database of Systematic Reviews 2008, Issue 1.
Secondary outcomes pre-specified include:

1. Neurodevelopmental impairment (i.e. rates of cerebral palsy, cognitive delay defined as a MDI score $<70$ ( 2 SD below the mean of 100) on the BSID II (Bayley 1993), deafness, blindness, or composite reported at 18 months' corrected age or later)
"The evidence available from randomised controlled trials suggested that delaying the introduction of progressive enteral feeds beyond four days after birth did not reduce the risk of developing NEC in very preterm or VLBW infants, including growth-restricted infants. Delaying the introduction of progressive enteral feeds resulted in a few days' delay in establishing full enteral feeds but the clinical importance of this effect was unclear. The applicability of these findings to extremely preterm or extremely low birth weight was uncertain. Further randomised controlled trials in this population may be warranted"
O'Donnell CPF, Bruschettini M, Davis PG, Morley CJ, Moja L, Calevo MG, Zappettini S. Sustained versus standard inflations during neonatal resuscitation to prevent mortality and improve respiratory outcomes. Cochrane Database of Systematic Reviews 2015, Issue 7.
Secondary outcomes pre-specified include:

1. Long-term neurodevelopmental outcome (rates of cerebral palsy on physician assessment, developmental delay, i.e. IQ 2 $\mathrm{SD}<$ mean on validated assessment tools, e.g. BSID MDI)
"Prophylactic surgical ligation of the PDA did not decrease mortality or BPD in ELBW infants. A significant reduction of stage II or III NEC was noted. Based on the current evidence, the high rate of spontaneous closure, availability of effective safe medical therapies, and the potential short and long-term complications of surgical ligation, the use such prophylactic surgical therapy is not indicated in the management of the preterm infants"
Ogunlesi TA, Odigwe CC, Oladapo OT. Adjuvant corticosteroids for reducing death in neonatal bacterial meningitis. Cochrane Database of Systematic Reviews 2015, Issue 11.
Secondary outcomes pre-specified include:

1. Presence of severe neurological deficits or developmental delay between 1 and 2 years of age (a neurological deficit was defined as a functional abnormality of a body area that is observed as the result of an abnormality in function of the brain, spinal cord, muscles, or nerves; developmental delay was defined as any significant lag in a child's physical or motor, cognitive, behavioural, emotional, or social development, in comparison with other children of the same age and sex within similar environments; formal eval-
"At present there is insufficient evidence from clinical trials to determine the efficacy and safety of initial sustained lung inflation for newborn infants resuscitated with PPV. RCTs comparing PPV with and without sustained inflations at neonatal resuscitation are warranted"
"Very low-quality data from two randomised controlled trials suggest that some reduction in death and hearing loss may result from use of adjunctive steroids alongside standard antibiotic therapy for treatment of patients with neonatal meningitis. Benefit is not yet seen with regards to reduction in neurological sequelae. Researchers who wish to clarify these findings must conduct more robustly designed trials with greater numbers of participants, evaluating more relevant outcomes and providing adequate follow-up" 
(Continued)

uation tools were used to assess neurological deficits and developmental delay). Examples of neurological deficits include mental retardation, cerebral palsy, epilepsy, blindness, and behavioural disorders. We considered evaluation tools such as BSID or GMDS (for neurodevelopmental deficits), the GMFCS or the Movement $A B C$ (forcerebral palsy), the Sonken-Silver VA test (for blindness), distraction tests (for behavioural disorders), and electroencephalography (for epilepsy) - all applied between 1 and 2 years of age. We also accepted other measures used by individual trialists to evaluate and document neurological deficits in their respective trials

Onland W, Offringa $\mathrm{M}$, van Kaam A. Late $(\geq 7$ days) inhalation corticosteroids to reduce bronchopulmonary dysplasia in preterm infants. Cochrane Database of Systematic Reviews 2012, Issue 4.
Secondary outcomes pre-specified include:

1. Long-term neurodevelopmental sequelae, assessed after at least 1 year CGA and before a CGA of 4 years includingcerebral palsy and BSID (MDI)
"Based on the results of the currently available evidence, inhalation corticosteroids initiated at $\geq 7$ days of life for preterm infants at high risk of developing BPD cannot be recommended at this point in time. More and larger randomised, placebo-controlled trials are needed to establish the efficacy and safety of inhalation corticosteroids"
Osborn DA, Evans NJ. Early volume expansion versus inotrope for prevention of morbidity and mortality in very preterm infants. Cochrane Database of Systematic Reviews 2001, Issue 2.
Primary outcomes pre-specified include:

1. Neurodevelopmental disability (neurological abnormality includingcerebral palsy, developmental delay, or sensory impairment)
"Dopamine was more successful than albumin at correcting low BP in hypotensive preterm infants, many of whom had already received volume. Neither intervention has been shown to be superior at improving blood flow or in improving mortality and morbidity in preterm infants. The trials do not allow any firm conclusions to be made as to whether or when volume or dopamine should be used in preterm infants"
Osborn DA, Hunt R. Postnatal thyroid hormones for preterm infants with transient hypothyroxinaemia. Cochrane Database of Systematic Reviews 2007, Issue 1.

\section{Primary outcomes pre-specified include:}

1. Neurodevelopmental status at follow-up. Neurodevelopmental outcome was categorised as:

a. Abnormal mental developmental $>12$ months' corrected age (a development or IQ > 2 SD below the mean of a standardised test)

b. Abnormal neurological outcome (infants with abnormal mental development or definite cerebral palsy)

c. Motor deficits

d. Sensorineural impairments including hearing deficit requiring aids; $\mathrm{VA}<6 / 60$

\section{Osborn DA, Hunt R.} Postnatal thyroid hormones for respiratory distress syndrome in preterm infants.

Cochrane Database of
Primary outcomes pre-specified include:

1. Abnormal neurodevelopmental outcome:

a. Abnormal mental development $>12$ months' corrected age (a validated de-
"There is insufficient evidence to determine whether use of thyroid hormones for treatment of preterm infants with transient hypothyroxinaemia results in changes in neonatal morbidity and mortality, or reductions in neurodevelopmental impairments. Further research is required"
"There is no evidence from controlled clinical trials that postnatal thyroid hormone treatment reduces the severity of respiratory distress syndrome, neonatal morbidity or mortality in preterm infants with respiratory distress syndrome" 
(Continued)

Systematic Reviews

2007, Issue 1. velopment or IQ > 2 SD below the mean

of a standardised test)

b. Abnormal neurological outcome (infants with abnormal mental development or definite cerebral palsy)

c. Motor deficits

d. Sensorineural impairments (hearing deficit requiring aids or $\mathrm{VA}<6 / 60$ )
Özek E, Soll R, Schimmel MS. Partial exchange transfusion to prevent neurodevelopmental disability in infants with polycythemia. Cochrane Database of Systematic Reviews 2010, Issue 1.
Primary outcomes pre-specified include:

1. Neurodevelopmental status at 2 years of age, neurodevelopmental status at school age. This will include both combined and separate analyses of the components of severe neurodevelopmental delay defined as an $\mathrm{MDI}<70$, cerebral palsy, vision loss, and hearing loss
Paradisis M, Osborn DA. Adrenaline for prevention of morbidity and mortality in preterm infants with cardiovascular compromise. Cochrane Database of Systematic Reviews 2004, Issue 1.

\section{Primary outcomes pre-specified include:}

1. Long-term neurodevelopmental outcome: cerebral palsy and standardised assessment of developmental delay or sensorineural impairment
"There are no proven clinically significant short or longterm benefits of PET in polycythemic newborn infants who are clinically well or who have minor symptoms related to hyperviscosity. PET may lead to an increase in the risk of NEC. The data regarding developmental follow-up are extremely imprecise due to the large number of surviving infants who were not assessed and, therefore, the true risks and benefits of PET are unclear"
Pfister RH, Soll R, Wiswell TE. Pro-

tein-containing synthetic surfactant versus protein-free synthetic surfactant for the prevention and treatment of respiratory distress syndrome. Cochrane Database of Systematic Reviews 2009, Issue 4.
Secondary outcomes pre-specified include:

1. Neurodevelopmental outcome at approximately 2 years' corrected age (acceptable range 18 months to 28 months) including cerebral palsy, mental delay (BSID $\mathrm{MDI}<70$ ), legal blindness (<20/200 VA), and hearing deficit (aided or $<60 \mathrm{~dB}$ on audiometric testing). The composite outcome "neurodevelopmental impairment" was defined as having any 1 of the aforementioned deficits
"There are insufficient data on the use of adrenaline infusions in preterm infants with cardiovascular compromise to make recommendations for practice. There is a need for larger trials to determine whether adrenaline is effective in reducing morbidity and mortality in preterm infants with cardiovascular compromise"
Pfister RH, Soll R, Wiswell TE. Protein containing synthetic surfactant versus animal derived surfactant extract for the prevention and treatment of respiratory distress syndrome. Cochrane Database of Systematic Reviews 2007, Issue 4.
Secondary outcomes pre-specified include:

1. Neurodevelopmental outcome at approximately 2 years' corrected age (range 18 months to 28 months) including cerebral palsy, mental retardation (BSID MDI < 70), legal blindness $(<20 / 200 \mathrm{VA})$, and hearing deficit (aided or $<60 \mathrm{~dB}$ on audiometric testing). The composite outcome "neurodevelopmental impairment" was defined as having any 1 of the aforementioned deficits
"In the one trial comparing protein containing synthetic surfactants compared to protein free synthetic surfactant for the prevention of RDS, no statistically different clinical differences in death and chronic lung disease were noted. Clinical outcomes between the two groups were generally similar although the group receiving protein containing synthetic surfactants did have decreased incidence of respiratory distress syndrome. Further well designed studies comparing protein containing synthetic surfactant to the more widely used animal derived surfactant extracts are indicated"
"In two trials of protein containing synthetic surfactants compared to animal derived surfactant extract, no statistically different clinical differences in death and chronic lung disease were noted. In general, clinical outcomes between the two groups were similar. Further well designed studies of adequate size and power will help confirm and refine these findings"

\footnotetext{
Pilley E, McGuire W. Pre-discharge "car seat challenge" for preventing morbidity and mortality in preterm infants.
}

\section{Secondary outcomes pre-specified include:}

1. Neurodevelopmental outcomes at $>12$ months post term measured using validated assessment tools such as BSID and
No included trials

"It is unclear whether undertaking a pre-discharge car seat challenge is beneficial or harmful to preterm infants. Further studies are needed to determine whether the car 
(Continued)

Cochrane Database of Systematic Reviews 2006, Issue 1. classifications of disability, including auditory and visual disability. The composite outcome "severe neurodevelopmental disability" will be defined as any 1 or combination of the following: non-ambulantcerebral palsy, developmental delay (DQ $<70)$, auditory and visual impairment seat challenge accurately predicts the risk of clinically significant adverse events in preterm infants travelling in car seats. If this is shown to be the case then a large randomised controlled trial is needed to provide an unbiased assessment of its utility in pre-discharge assessment"
Quigley M, McGuire W. Formula versus donor breast milk for feeding preterm or low birth weight infants. Cochrane Database of Systematic Reviews 2014, Issue 4.
Primary outcomes pre-specified include:

1. Death or severe neurodevelopmental disability defined as any 1 or combination of the following: non-ambulant cerebral palsy, developmental delay (DQ < 70), auditory and visual impairment. We analysed each component individually as well as part of the composite outcome
"In preterm and low birth weight infants, feeding with formula compared with donor breast milk results in a higher rate of short-term growth but also a higher risk of developing necrotising enterocolitis. Limited data on the comparison of feeding with formula versus nutrient-fortified donor breast milk are available. This limits the applicability of the findings of this review as nutrient fortification of breast milk is now a common practice in neonatal care. Future trials may compare growth, development and adverse outcomes in infants who receive formula milk versus nutrient-fortified donor breast milk given as a supplement to maternal expressed breast milk or as a sole diet"

"Administration of prophylactic D-penicillamine in preterm infants does not prevent acute or severe ROP, death or neurodevelopmental delay. D-penicillamine cannot be recommended for the prevention of ROP based on the available evidence"
Qureshi MJ, Kumar M. D-Penicillamine for preventing retinopathy of prematurity in preterm infants. Cochrane Database of Systematic Reviews 2013, Issue 9.
Secondary outcomes pre-specified include:

1. Abnormal neurodevelopment defined as abnormal neurological examination, epilepsy,cerebral palsy, or DQ $<70$ diag nosed at 1 year of corrected age or older
Rojas-Reyes MX, Morley CJ, Soll R. Prophylactic versus selective use of surfactant in preventing morbidity and mortality in preterm infants. Cochrane Database of Systematic Reviews 2012, Issue 3 .
Secondary outcomes pre-specified include:

\section{Cerebral palsy.}

2. Neurodevelopmental outcome at approximately 2 years' corrected age (acceptable range 18 months to 28 months) including cerebral palsy, significant mental developmental delay (BSID $<70$ ), legal blindness $(<20 / 200 \mathrm{VA})$, and hearing deficit (aided or $<60 \mathrm{~dB}$ on audiometric testing). The composite outcome "neurodevelopmental impairment" was defined as having any one of the aforementioned deficits

(Review notes that 2 RCTs have reported on cerebral palsy, but not in the 'acceptable range' pre-specified; therefore no results were reported:

"Neurodevelopmental outcome: For this outcome, we considered any trial reporting at approximately 2 years' corrected age (acceptable range 18 months to 28 months) any of the following entities cerebral palsy, intellectual disability or developmental delay (Bayley Scales of Infant Development Mental Developmental Index $<70$ ), legal blindness $(<20 / 200$ visual acuity), and hearing deficit (aided or $<60 \mathrm{~dB}$ on audiometric testing). The composite outcome "neurodevelopmental impairment" would be defined as having any one of the aforementioned deficits. Two
"Although the early trials of prophylactic surfactant administration to infants judged to be at risk of developing RDS compared with selective use of surfactant in infants with established RDS demonstrated a decreased risk of air leak and mortality, recent large trials that reflect current practice (including greater utilization of maternal steroids and routine post delivery stabilization on CPAP) do not support these differences and demonstrate less risk of chronic lung disease or death when using early stabilization on CPAP with selective surfactant administration to infants requiring intubation" 
(Continued)

trials Sinkin 1998; Vaucher 1993 performed a follow-up study including infants recruited in the Kendig 1991 and Merritt 1991 trials respectively. Sinkin 1998 reported cerebral palsy but in 148 children at school age, no data were available from ages between 18 and 28 months. Vaucher 1993 reported on cerebral palsy and developmental delay in 145 survivors at 12 months' corrected age. No one study reporting neurodevelopmental outcomes at 24 months' corrected age was found")

Rojas-Reyes MX, Orrego-Rojas PA. Rescue high-frequency jet ventilation versus conventional ventilation for severe pulmonary dysfunction in preterm infants. Cochrane Database of Systematic Reviews 2015, Issue 10.
Secondary outcomes pre-specified include:

1. Long-term neurodevelopmental outcome (measured at approximately 2 years' corrected age; acceptable range 18 months to 28 months) including cerebral palsy, delayed neurodevelopment (BSID MDI < 70), legal blindness ( $<20 / 200 \mathrm{VA})$, and hearing deficit (aided or $<60 \mathrm{~dB}$ on audiometric testing); impairment defined as including any of the aforementioned deficits
"Study authors reported no significant differences in overall mortality between rescue high-frequency jet ventilation and conventional ventilation and presented highly imprecise results for important adverse effects such as intraventricular haemorrhage, new air leaks, airway obstruction and necrotising tracheobronchitis. The overall quality of evidence is affected by limitations in trial design and by imprecision due to the small number of infants in the included study. Existing evidence does not support the use of high-frequency jet ventilation as rescue therapy in preterm infants. Studies that target populations at greatest risk and that have sufficient power to assess important outcomes are needed. These trials should incorporate long-term pulmonary and neurodevelopmental outcomes"
Romantsik O, Bruschettini M, Zappettini S, Ramenghi LA, Calevo MG. Heparin for the treatment of thrombosis in neonates. Cochrane Database of Systematic Reviews 2016, Issue 11.
Secondary outcomes pre-specified include:

1. Major neurodevelopmental disability, that is, (1) cerebral palsy on physician assessment (yes/no); (2) developmental delay or intellectual impairment: BSID or GMDS assessment $>2$ SD below the mean, or intellectual impairment (IQ $>2$ SD below the mean); neuromotor development (BSID PDI) assessed in survivors; mental development (BSID MDI) assessed in survivors; (3) blindness vision ( $<6 / 60$ in both eyes); or (4) sensorineural deafness requiring amplification. We will report these components of this long-term outcome for all trials that have assessed children after 18 months' chronological age. We will perform separate analyses for children aged 18 to 24 months and for those aged 3 to 5 years
"We found no studies that met our inclusion criteria and no evidence from randomized controlled trials to recommend or refute the use of heparin for treatment of neonates with thrombosis"
Sankar MJ, Sankar J, Mehta M, Bhat V, Srinivasan R. Anti-vascular endothelial growth factor (VEGF) drugs for treatment of retinopathy of prematurity. Cochrane Database of Systematic Reviews 2016, Issue 2.

\section{Secondary outcomes pre-specified include:}

1. Adverse neurodevelopmental outcomes at 18 months to 24 months' corrected age:

a. Cerebral palsy and/or

b. Moderate to severe developmental delay as assessed on performance in formal neurodevelopmental testing such as the BSID scale
"Implications for practice: Intravitreal bevacizumab reduces the risk of refractive errors during childhood when used as monotherapy while intravitreal pegaptanib reduces the risk of retinal detachment when used in conjunction with laser therapy in infants with type 1 ROP. Quality of evidence was, however, low for both the outcomes because of the risk of detection and other biases. Effect on other critical outcomes and, more importantly, the long-term systemic adverse effects of the drugs are not known. The insufficient data precludes strong conclusions favouring routine use of intravitreal anti-VEGF 
agents in preterm infants with type 1 ROP. Implications for research: Further studies are needed to evaluate the effect of anti-VEGF agents on structural and functional outcomes in childhood and delayed systemic adverse effects such as myocardial dysfunction and adverse neurodevelopmental outcomes"

Schulzke SM, Kaempfen S, Trachsel D, Patole SK. Physical activity programs for promoting bone mineralization and growth in preterm infants. Cochrane Database of Systematic Reviews 2014, Issue 4.
Secondary outcomes pre-specified include:

1. Neurodevelopmental abnormalities at 18 to 24 months' corrected age or later:

\section{a. Cerebral palsy}

b. Developmental delay (assessed by standardised and validated test, e.g. GMDS or BSID test, with abnormality defined as $>2$ SD below the mean)

c. Intellectual impairment (IQ $>2$ SD below the mean as assessed by a standardised and validated test)

d. Blindness (vision <6/60 in both eyes)

e. Sensorineural deafness requiring amplification
"Some evidence suggests that physical activity programs might promote short-term weight gain and bone mineralization in preterm infants. Data are inadequate to allow assessment of harm or long-term effects. Current evidence does not support the routine use of physical activity programs in preterm infants. Further trials incorporating infants with a high baseline risk of osteopenia are required. These trials should address adverse events, longterm outcomes, and the effects of nutritional intake (calories, protein, calcium, phosphorus)"
Shah PS, Ohlsson A. Alpha-1 proteinase inhibitor (a1PI) for preventing chronic lung disease in preterm infants. Cochrane Database of Systematic Reviews 2001, Issue 3.
Secondary outcomes pre-specified include:

1. Long-term neurodevelopmental outcome (frequency of cerebral palsy and/or mental retardation, legal blindness, and /or deafness)

(Review reports on 'Developmental delay amongst infants assessed' for 1 RCT (83 infants); however it was not clear whether this included cerebral palsy (in review or RCT (published as abstract only))
Shah PS, Kaufman DA. Antistaphylococcal immunoglobulins to prevent staphylococcal infection in very low birth weight infants. Cochrane Database of Systematic Reviews 2009, Issue 2.
Secondary outcomes pre-specified include:

1. Neurodevelopmental disability at 18 to 24 months (includingcerebral palsy, cognitive impairment, deafness, and blindness)
"Prophylactic administration of a1PI did not reduce the risk of CLD at 36 weeks or long term adverse developmental outcomes in preterm neonates"
Shah SS, Ohlsson A, Halliday HL, Shah VS. Inhaled versus systemic corticosteroids for preventing chronic lung disease in ventilated very low birth weight preterm neonates. Cochrane Database of Systematic Reviews 2012, Issue 5.
Secondary outcomes pre-specified include:

1. Long-term neurodevelopmental outcome: Neurodevelopmental impairment was defined as presence of cerebral palsy and/or mental retardation (BSID MDI $<70$ ) and/or legal blindness (<20/200 VA) and/ or deafness (aided or $<60 \mathrm{~dB}$ on audiometric testing) assessed at 18 to 24 months
"Antistaphylococcal immunoglobulins (INH A-21 and Altastaph) are not recommended for prevention of staphylococcal infections in preterm or VLBW neonates. Further research to investigate the efficacy of other products such as Pagibaximab is needed"
"This review found no evidence that early inhaled steroids confer important advantages over systemic steroids in the management of ventilator dependent preterm infants. Neither inhaled steroids nor systemic steroids can be recommended as a part of standard practice for ventilated preterm infants. Because they might have fewer adverse effects than systemic steroids, further randomised controlled trials of inhaled steroids are needed that address risk/benefit ratio of different delivery techniques, dosing schedules and long-term effects, with particular attention to neurodevelopmental outcome" 
(Continued)

Inhaled versus systemic corticosteroids for the treatment of chronic lung disease in ventilated very low birth weight preterm infants. Cochrane Database of Systematic Reviews 2012, Issue 5.
1. Long-term neurodevelopmental outcome: Neurodevelopmental impairment is defined as presence of cerebral palsy and/or mental retardation (BSID MDI < 70) and/or legal blindness (<20/200 VA) and/ or deafness (aided or $<60 \mathrm{~dB}$ on audiometric testing) assessed at 18 to 24 months teroids in the management of ventilator dependent preterm infants. Neither inhaled steroids nor systemic steroids can be recommended as standard treatment for ventilated preterm infants. There was no evidence of difference in effectiveness or side-effect profiles for inhaled versus systemic steroids. A better delivery system guaranteeing selective delivery of inhaled steroids to the alveoli might result in beneficial clinical effects without increasing side-effects. To resolve this issue, studies are needed to identify the risk/benefit ratio of different delivery techniques and dosing schedules for the administration of these medications. The long-term effects of inhaled steroids, with particular attention to neurodevelopmental outcome, should be addressed in future studies"

"Sildenafil in the treatment of PPHN has significant potential especially in resource limited settings. However, a large scale randomised trial comparing sildenafil with the currently used vasodilator, inhaled nitric oxide, is needed to assess efficacy and safety"
Shah PS, Ohlsson

A. Sildenafil for pulmonary hypertension in neonates. Cochrane Database of Systematic Reviews 2011, Issue 8.
Secondary outcomes pre-specified include:

1. Neurodevelopmental disability at 18 to 24 months (including cerebral palsy, cognitive impairment, deafness, and blindness)

\author{
Sinclair JC, Bottino \\ M, Cowett RM. Inter- \\ ventions for preven- \\ tion of neonatal hyper- \\ glycemia in very low \\ birth weight infants. \\ Cochrane Database of \\ Systematic Reviews \\ 2011, Issue 10.
}

\section{Primary outcomes pre-specified include:}

1. Neurodevelopmental impairment defined as presence of 1 or more of the following: cerebral palsy, MDI or PDI < 70, blindness or deafness assessed between 18 and 24 months' post-menstrual age or at latest assessment up to 24 months' corrected age
Singh N, Halliday HL, Stevens TP, Suresh G, Soll R, Rojas-Reyes MX. Comparison of animal-derived surfactants for the prevention and treatment of respiratory distress syndrome in preterm infants. Cochrane Database of Systematic Reviews 2015, Issue 12.

\section{Secondary outcomes pre-specified include:}

1. Cerebral palsy at approximately 2 years' corrected age (as defined by the study authors)

2. Neurodevelopmental outcome at approximately 2 years' corrected age (acceptable range 18 months to 28 months) including cerebral palsy, delayed neurodevelopment (BSID MDI < 70), legal blindness (< 20/200 VA), and hearing deficit (aided or $<$ $60 \mathrm{~dB}$ on audiometric testing). The composite outcome 'neurodevelopmental impairment' was defined as having any 1 of the aforementioned deficits

\begin{abstract}
"Glucose infusion rate: There is insufficient evidence from trials comparing lower with higher glucose infusion rates to inform clinical practice. Large randomized trials are needed, powered on clinical outcomes including death, major morbidities and adverse neurodevelopment. Insulin infusion: The evidence reviewed does not support the routine use of insulin infusions to prevent hyperglycemia in VLBW neonates. Further randomized trials of insulin infusion may be justified. They should enrol extremely low birth weight neonates at very high risk for hyperglycemia and neonatal death. They might use real time glucose monitors if these are validated for clinical use. Refinement of algorithms to guide insulin infusion is needed to enable tight control of glucose concentrations within the target range"
\end{abstract}

"Significant differences in clinical outcome were noted in the comparison trials of modified minced lung surfactant extract (beractant) compared with porcine minced lung surfactant extract (poractant alfa) including a significant increase in the risk of mortality prior to discharge, death or oxygen requirement at 36 weeks' postmenstrual age, PDA requiring treatment and "receiving $>1$ dose of surfactant" in infants treated with modified bovine minced lung surfactant extract compared with porcine minced lung surfactant extract. The difference in these outcomes was limited to studies using a higher initial dose of porcine minced lung surfactant extract. It is uncertain whether the observed differences are from differences in dose or from source of extraction (porcine vs. bovine) because of the lack of dose-equivalent comparison groups with appropriate sample size. No differences in clinical outcomes were observed in comparative trials between bovine lung lavage surfactant and modified bovine minced lung surfactants"
Soll R, Özek E. Prophylactic animal de-
Secondary outcomes pre-specified include:

"Prophylactic intratracheal administration of animal derived surfactant extract to infants judged to be at risk 
(Continued) rived surfactant extract for preventing morbidity and mortality in preterm infants. Cochrane Database of Systematic Reviews 1997, Issue 4.

\section{Cerebral palsy}

2. Neurodevelopmental outcome at approximately 2 years' corrected age (acceptable range 18 months to 28 months) including cerebral palsy, mental retardation (BSID $\mathrm{MDI}<70$ ), legal blindness (<20/200 VA), and hearing deficit (aided or $<60 \mathrm{~dB}$ on audiometric testing). The composite outcome "neurodevelopmental impairment" will be defined as having any 1 of the aforementioned deficits

\author{
Stevens TP, Blennow M, \\ Myers EH, Soll R. Ear- \\ ly surfactant adminis- \\ tration with brief venti- \\ lation vs. selective sur- \\ factant and continued \\ mechanical ventilation \\ for preterm infants with \\ or at risk for respirato- \\ ry distress syndrome. \\ Cochrane Database of \\ Systematic Reviews \\ 2007, Issue 4.
}

of developing respiratory distress syndrome has been demonstrated to improve clinical outcome. Infants who receive prophylactic animal derived surfactant extract have a decreased risk of pneumothorax, a decreased risk of PIE, a decreased risk of mortality, and a decreased risk of BPD or death"
Secondary outcomes pre-specified include:

1. Neurodevelopmental outcome at hospital discharge and at a later time point (> 1 year post-conceptional age). Neurodevelopmental impairment is defined as the presence of cerebral palsy and/or mental retardation (BSID MDI < 70) and/or legal blindness (<20/200 VA) and/or deafness (aided or $<60 \mathrm{~dB}$ on audiometric testing)
"Early surfactant replacement therapy with extubation to NCPAP compared with later selective surfactant replacement and continued mechanical ventilation with extubation from low ventilator support is associated with less need mechanical ventilation, lower incidence of BPD and fewer air leak syndromes. A lower treatment threshold $(\mathrm{FIO} 2<0.45)$ confers greater advantage in reducing the incidences of airleak syndromes and BPD; moreover a higher treatment threshold (FIO2 at study $>0.45$ ) was associated with increased risk of PDA. These data suggest that treatment with surfactant by transient intubation using a low treatment threshold $(\mathrm{FIO} 2<0.45)$ is preferable to later, selective surfactant therapy by transient intubation using a higher threshold for study entry $(\mathrm{FIO} 2>0.45)$ or at the time of respiratory failure and initiation of mechanical ventilation"

\section{No included trials}

"There are no data from randomised trials to either support or refute the use of antibiotic prophylaxis for intercostal catheter insertion in neonates. Any randomised controlled trials of antibiotic prophylaxis would need to account for the fact that neonates who require insertion of an intercostal catheter may already be receiving antibiotics for other indications"

Cochrane Database of

Systematic Reviews 2012, Issue 4.

Subramaniam P, Ho JJ, Davis PG. Prophylactic nasal continuous positive airway pressure for preventing morbidity and mortality in very preterm infants. Cochrane Database of Systematic Reviews 2016, Issue 6.
Secondary outcomes pre-specified include:

1. Neurodevelopmental status at follow-up: neurodevelopment measured on a validated scale that measures cognitive, motor, behavioural function, or blindness, deafness, or cerebral palsy at about 2 years of age
"There is insufficient evidence to evaluate prophylactic CPAP compared to oxygen therapy and other supportive care. However when compared to mechanical ventilation prophylactic nasal CPAP in very preterm infants reduces the need for mechanical ventilation and surfactant and also reduces the incidence of BPD and death or BPD"
Tan K, Lai NM, Sharma A. Surfactant for bacterial pneumonia in late preterm and term infants. Cochrane Database of Systematic Reviews 2012, Issue 2.

\section{Secondary outcomes pre-specified include:}

1. Long-term neurological outcomes (cerebral palsy, development measured by BSID or GMDS, intellectual function measured by IQ score, and presence of visual or hearing impairments) at 18 months of age or greater

\section{No included trials}

"There is no evidence from randomised controlled trials (RCTs) to support or refute the efficacy of surfactant in near-term and term infants with proven or suspected bacterial pneumonia. RCTs are still required to answer this question" 
(Continued)

Thayyil S, Milligan D. Single versus double volume exchange transfusion in jaundiced newborn infants. Cochrane Database of Systematic Reviews 2006, Issue 4.
Primary outcomes pre-specified include:

1. Neurological deficits consistent with kernicterus at 2 years of age including athetoidcerebral palsy, impaired upward gaze and deafness, AN/AD, and subtle BIND (Shapiro 2005)

Secondary outcomes pre-specified include:

1. Neurological deficits or neurodisabilty defined as any of deafness, cerebral palsy, or cognitive delay (score > 2 SD below the mean for any recognised test for neurodevelopment, e.g. BSID)
Vasudevan C, Oddie SJ, McGuire W. Early removal versus expectant management of central venous catheters in neonates with bloodstream infection. Cochrane Database of Systematic Reviews 2016, Issue 4.

\section{Primary outcomes pre-specified include:}

1. Neurodevelopmental outcomes assessed after 12 months' post-menstrual age using validated tools: neurological evaluations, developmental scores, and classifications of disability, including auditory and visual disability. We will define neurodevelopmental impairment as the presence of 1 or more of the following: non-ambulant cerebral palsy, developmental delay (DQ $>2 \mathrm{SD}$ below population mean), blindness (VA $<6 / 60$ ), or deafness (any hearing impairment requiring or unimproved by amplification)
"There was insufficient evidence to support or refute the use of single volume exchange transfusion as opposed to double volume exchange transfusion in jaundiced newborns. A change from the current practice of double volume exchange transfusions for severe jaundice in newborns infant, cannot be recommended on current evidence"

\section{No included trials}

"There are no trial data to guide practice regarding early removal versus expectant management of central venous catheters in newborn infants with bloodstream infections. A simple and pragmatic randomised controlled trial is needed to resolve the uncertainty about optimal management in this common and important clinical scenario"
Verner AM, McGuire W, Craig JS. Effect of taurine supplementation on growth and development in preterm or low birth weight infants. Cochrane Database of Systematic Reviews 2007, Issue 4.
Secondary outcomes pre-specified include:

\section{Development}

a. Neurodevelopmental outcomes at $\geq 12$ months of age (corrected for preterm birth) measured using validated assessment tools

b. Severe neurodevelopmental disability defined as any 1 or combination of the following: non-ambulant cerebral palsy, developmental delay ( $\mathrm{DQ}<70)$, auditory and visual impairment

c. Cognitive and educational outcomes at $>5$ years old: IQ and/or indices of educational achievement measured using a validated assessment tool (including school examination results)
"Despite that lack of evidence of benefit from randomised controlled trials, it is likely that taurine will continue to be added to formula milks and parenteral nutrition solutions used for feeding preterm and low birth weight infants given the putative association of taurine deficiency with various adverse outcomes. Further randomised controlled trials of taurine supplementation versus no supplementation in preterm or low birth weight infants are unlikely to be viewed as a research priority, but there may be issues related to dose or duration of supplementation in specific subgroups of infants that merit further research"
Watson J, McGuire W. Responsive versus scheduled feeding for preterm infants. Cochrane Database of Systematic Reviews 2016, Issue 8.
Secondary outcomes pre-specified include:

1. Neurodevelopmental outcomes at $>12$ months' corrected age measured using validated assessment tools such as BSID and classifications of disability including auditory and visual disability. We defined the composite outcome 'severe neurodevelopmental disability' as any 1 or combination of the following: non-ambulant
"Overall, the data do not provide strong or consistent evidence that responsive feeding affects important outcomes for preterm infants or their families. Some (low quality) evidence exists that preterm infants fed in response to feeding and satiation cues achieve full oral feeding earlier than infants fed prescribed volumes at scheduled intervals. This finding should be interpreted cautiously because of methodological weaknesses in the included trials. A large RCT would be needed to con- 
cerebral palsy, developmental delay (DQ $<70$ ), auditory and visual impairment

Wilkinson $D$, Andersen C, O'Donnell CPF, De Paoli AG, Manley BJ. High flow nasal cannula for respiratory support in preterm infants. Cochrane Database of Systematic Reviews 2016, Issue 2.
Secondary outcomes pre-specified include:

1. Long-term neurodevelopmental outcome (rates of cerebral palsy on physician assessment, developmental delay, i.e. IQ 2 $\mathrm{SD}<$ mean on validated assessment tools such as BSID MDI), blindness, hearing impairment requiring amplification firm this finding and to determine if responsive feeding of preterm infants affects other important outcomes"
"HFNC has similar rates of efficacy to other forms of noninvasive respiratory support in preterm infants for preventing treatment failure, death and CLD. Most evidence is available for the use of HFNC as post-extubation support. Following extubation, HFNC is associated with less nasal trauma, and may be associated with reduced pneumothorax compared with nasal CPAP. Further adequately powered randomised controlled trials should be undertaken in preterm infants comparing HFNC with other forms of primary non-invasive support after birth and for weaning from non-invasive support. Further evidence is also required for evaluating the safety and efficacy of HFNC in extremely preterm and mildly preterm subgroups, and for comparing different HFNC devices"
Wong V, Cheuk DKL, Chu V. Acupuncture for hypoxic ischemic encephalopathy in neonates. Cochrane Database of Systematic Reviews 2013, Issue 1.

\section{Primary outcomes pre-specified include:}

1. Long-term (> 12 months) major neurodevelopmental disability such as cerebral palsy, developmental delay (BSID or GMDS assessment $>2$ SD below the mean) or intellectual impairment (IQ $>2$ SD below mean), blindness (vision $<6 / 60$ in both eyes), sensorineural deafness requiring amplification, or any combination of these disabilities

\section{No included trials}

"The rationale for acupuncture in neonates with HIE is unclear and the evidence from randomized controlled trial is lacking. Therefore, we do not recommend acupuncture for the treatment of HIE in neonates. High quality randomized controlled trials on acupuncture for HIE in neonates are needed"
Woodgate PG, Flenady V, Steer PA. Intramuscular penicillin for the prevention of early onset group B streptococcal infection in newborn infants. Cochrane Database of Systematic Reviews 2004, Issue 2.
Secondary outcomes pre-specified include:

1. Neurodevelopmental outcome (cerebral palsy, sensorineural hearing loss, visual impairment, developmental delay)
"This review does not support the routine use of intramuscular penicillin to prevent EOGBSD in newborn infants. There is a discrepancy between this finding and the results of a number of larger non-randomised trials. Explanations for this are proposed. There is a need for this intervention to be tested as a component of the existing prevention strategies in widespread use"
Young L, Embleton ND, McCormick FM, McGuire W. Multinutrient fortification of human breast milk for preterm infants following hospital discharge. Cochrane Database of Systematic Reviews 2013, Issue 2.

\section{Primary outcomes pre-specified include:}

1. Development:

a. Neurodevelopmental outcomes assessed using validated tools at $>12$ months' corrected age and classifications of disability, including non-ambulant cerebral palsy, developmental delay, auditory and visual impairment

b. Cognitive and educational outcomes at > 5 years: IQ and/or indices of educational achievement measured using a validated tool (including school examination results)
"The limited available data do not provide convincing evidence that feeding preterm infants with multinutrient fortified breast milk compared with unfortified breast milk following hospital discharge affects important outcomes including growth rates during infancy. There are no data on long-term growth. Since fortifying breast milk for infants fed directly from the breast is logistically difficult and has the potential to interfere with breast feeding, it is important to determine if mothers would support further trials of this intervention"
Young L, Morgan J, McCormick FM, McGuire W. Nutrient-enriched formula versus standard term formula for
Primary outcomes pre-specified include:

1. Development:

a. Neurodevelopmental outcomes assessed using validated tools at $>12$ months' corrected age and classifica-
"Current recommendations to prescribe "post-discharge formula" for preterm infants following hospital discharge are not supported by the available evidence. Some limited evidence exists that feeding preterm infants following hospital discharge with "preterm formula" (which is 
(Continued) preterm infants following hospital discharge. Cochrane Database of Systematic Reviews 2012, Issue 3. tions of disability, including non-ambulantcerebral palsy, developmental delay, auditory and visual impairment

b. Cognitive and educational outcomes at $>5$ years: IQ and/or indices of educational achievement measured using a validated tool (including school examination results)
Ziino AJA, Davies MW, Davis PG. Epinephrine for the resuscitation of apparently stillborn or extremely bradycardic newborn infants. Cochrane Database of Systematic Reviews 2002, Issue 3.

\section{Primary outcomes pre-specified include:}

1. Severe disability at follow-up at 12 months, 24 months, and 5 years on, defined as any of blindness, deafness, cerebral palsy, or cognitive delay (score $>2$ SD below the mean for a recognised psychometric test, e.g. BSID)

Secondary outcomes pre-specified include:

1. Cerebral palsy at 12 and 24 months, and at 5 years generally only available for in-hospital use) may increase growth rates up to 18 months corrected age"

\section{No included trials}

"No randomised, controlled trials evaluating the administration of epinephrine to the apparently stillborn or extremely bradycardic newborn infant were found. Similarly, no randomised, controlled trials that addressed the issues of optimum dosage and route of administration of epinephrine were found. Current recommendations for the use of epinephrine in newborn infants are based only on evidence derived from animal models and the human adult literature. Randomised trials in neonates are urgently required to determine the role of epinephrine in this population"

Abbreviations: AN/AD: Auditory Neuropathy/Auditory Dyssynchrony; anti-VEGF: anti-vascular endothelial growth factor; BIND: bilirubininduced neurological dysfunction; BP: blood pressure; BPD: bronchopulmonary dysplasia; BSID: Bayley Scales of Infant Development; CDP: continuous distending pressure; CGA: corrected gestational age; CLD: chronic lung disease; CO2: carbon dioxide; CPAP: continuous positive airway pressure; CRBSI: catheter-related bloodstream infection; DQ: developmental quotient; ELBW: extremely low birthweight; EOGBSD: early-onset group B streptococcus disease; ETT: endotracheal tube; FIO2: fraction of inspired oxygen; GMDS: Griffith Mental Development Scales; GMFCS: Gross Motor Function Classification System; HFNC: high-flow nasal cannula; HIE: hypoxic-ischaemic encephalopathy; iNO: inhaled nitric oxide; IPPV: intermittent positive-pressure ventilation; IQ; intelligence quotient; IVH: intraventricular haemorrhage; LMA: laryngeal mask airway; MDI: Mental Development Index; Movement ABC: Movement Assessment Battery for Children; MV mechanical ventilation; NCPAP: nasal continuous positive airway pressure; NEC: necrotising enterocolitis; PDA: patent ductus arteriosus; PDI: Psychomotor Development Index; PET: partial exchange transfusion; PIE: pulmonary interstitial emphysema; PPHN: persistent pulmonary hypertension of the newborn; PPV: positive-pressure ventilation; RBCs: red blood cells; RCT: randomised controlled trial; RDS: respiratory distress syndrome; rhAPC: recombinant human activated protein C; ROP: retinopathy of prematurity; S-B: StanfordBinet; SD: standard deviation; TGI: tracheal gas insufflation; UVCs: umbilical venous catheters; VA: visual acuity; VLBW: very low birthweight.

\section{CONTRIBUTIONS OFAUTHORS}

Emily Shepherd, Rehana Abdus Salam, and Shanshan Han conducted screening, data extraction, and quality assessment of included reviews. Emily Shepherd drafted the first version of the overview, with Rehana Abdus Salam, Shanshan Han, Sarah McIntyre, Nadia Badawi, Maria Makrides, Philippa Middleton, and Caroline Crowther making comments and contributing to the final draft.

Emily Shepherd drafted the first version of the protocol for this review, with Sarah Mclntyre, Nadia Badawi, Maria Makrides, Philippa Middleton, and Caroline Crowther making comments and contributing to the final draft.

\section{DECLARATIONS OF INTEREST}

Emily Shepherd, Rehana Abdus Salam, Shanshan Han, Sarah McIntyre, Maria Makrides, Philippa Middleton, Caroline Crowther: none known.

Nadia Badawi was an author of one of the included reviews (Jones 2009). As pre-specified in our protocol, data extraction and quality assessment for this review were carried out by two other overview authors, who were not authors of this review.

\section{SOURCES OFSUPPORT}

\section{Internal sources}

- ARCH: Australian Research Centre for Health of Women and Babies, Robinson Research Institute, The University of Adelaide, Australia. 


\section{External sources}

- National Health and Medical Research Council, Australia.

Funding for the Pregnancy and Childbirth Australian and New Zealand Satellite

- Cerebral Palsy Alliance Research Foundation, Australia.

Project Grant: PG0914 - Interventions during the antenatal and neonatal period to prevent cerebral palsy: an overview of Cochrane systematic reviews (Shepherd E, Middleton P, Crowther CA)

- Eunice Kennedy Shriver National Institute of Child Health and Human Development, National Institutes of Health, Department of Health and Human Services, USA.

Editorial support of the Cochrane Neonatal Review Group has been funded with Federal funds from the Eunice Kennedy Shriver National Institute of Child Health and Human Development, National Institutes of Health, Department of Health and Human Services, USA, under Contract No. HHSN275201100016C

\section{N DEX TERMS}

\section{Medical Subject Headings (MeSH)}

Asphyxia Neonatorum [therapy]; Brain Diseases [therapy]; Cerebral Palsy [prevention \& control]; Hypothermia, Induced; Infant, Low Birth Weight; Infant, Premature; Review Literature as Topic

\section{MeSH check words}

Humans; Infant, Newborn 